
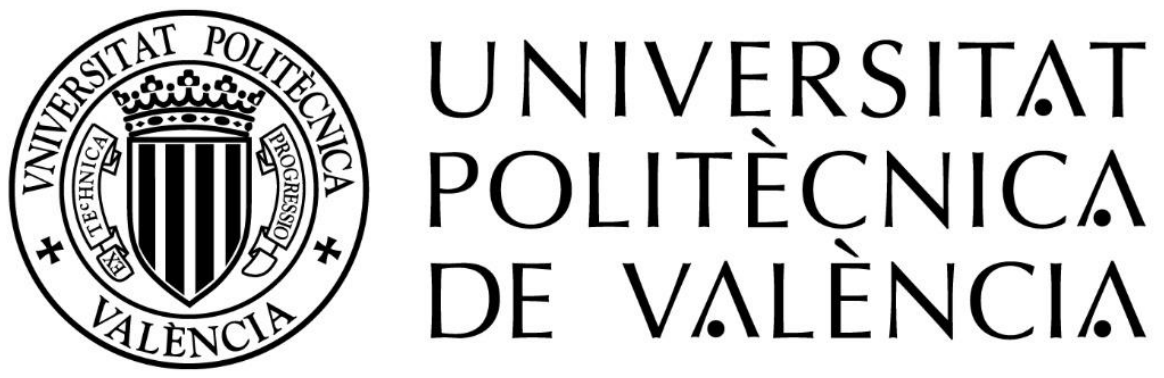

Escuela Técnica Superior de Ingeniería del Diseño

\title{
ANALYSIS OF METALLIC COATINGS BASED IN ZINC- ALUMINIUM-MAGNESIUM ALLOYS, IN TERMS OF PERFORMANCE AND LONG-TERM CORROSION. CASE STUDY: ELECTRICAL CABLE TRAYS SELECTION IN PROJECT DESIGN
}

Análisis de recubrimientos metálicos basados en aleaciones de cincaluminio-magnesio, en términos de comportamiento y resistencia a la corrosión a largo plazo

Caso de estudio: Selección de bandejas para la conducción de cables eléctricos en el Proyecto de Diseño

Programa de Doctorado en Diseño, Fabricación y Gestión de Proyectos Industriales

TESIS DOCTORAL

Presentada por: D. Ernesto Chenoll Mora

Dirigida por: Dr. D. Vicente Agustín Cloquell Ballester 
Thesis carried out under the direction of Professor PhD. Mr. Vicente Agustín Cloquell Ballester, through the Department of Engineering Projects, of the Polytechnic University of València, and that Mr. Ernesto Chenoll Mora presents to obtain the PhD’s degree.

Tesis realizada bajo la dirección del Profesor Doctor D. Vicente Agustín Cloquell Ballester, a través del Departamento de Proyectos de Ingeniería, de la Universidad Politécnica de València, y que, para la obtención del grado de Doctor, presenta D. Ernesto Chenoll Mora. 


\section{Dedication and thanks}

My gratitude goes to all those people, friends, colleagues and especially family, who gave me, not only their unconditional support, but a good part of their time, their knowledge, their patience and above all, the great motivation that the development of this work required, and that with so much effort, enthusiasm and many remains of my time, has finally managed to materialize.

Likewise, to all those professionals, who even beyond their daily work and the demands that life asks to any person in our society, take time where there isn't, to research and contribute with their knowledge to the state of science.

And especially to my parents. Without them, from the beginning, none of this would have been possible.

Dedicatoria y agradecimiento

Mi agradecimiento va dirigido a todas aquellas personas, amigos, compañeros y sobre todo familiares, que me dieron, no solo su apoyo incondicional, sino una buena parte de su tiempo, de su conocimiento, de su paciencia y sobre todo, de la gran motivación que el desarrollo de este trabajo exigía, y que con tanto esfuerzo, ilusión y muchísimos retales de mi tiempo, ha conseguido finalmente materializarse.

Igualmente, a todos aquellos profesionales, que aun por encima de su trabajo cotidiano y de la exigencia que la vida pide a cualquier persona de nuestra sociedad, sacan tiempo de donde no lo hay para la investigación y aportación de su conocimiento al estado de la ciencia.

$Y$ en especial a mis padres. Sin ellos, desde el principio, nada de esto hubiese sido posible. 
"The oxidation of metals in the hands of man is an operation subjected to the laws of proportion, determined by nature itself and unalterable by human will"

\section{Louis Proust}

"La oxidación de los metales en las manos del hombre es una operación sujeta a las leyes de la proporción, determinadas por la propia naturaleza e inalterable por la voluntad humana”

Louis Proust 


\section{Lines of investigation:}

- $\quad$ Applied corrosion of zinc in the field of the Industrial Project

- State of the science of zinc-aluminium-magnesium alloys and consolidation of existing knowledge.

- $\quad$ Real field tests, all over the world, on zinc-aluminium-magnesium alloys

- Comparison of traditional zinc-based coatings and zinc-aluminium-magnesiumbased alloys.

- Long-term behaviour forecast model for zinc-aluminium-magnesium alloys. Practical case.

\section{Líneas de investigación:}

- Corrosión aplicada del zinc en el ámbito del proyecto industrial

- Estado de la ciencia de las aleaciones de cinc-aluminio-magnesio y consolidación del conocimiento existente.

- Ensayos de campo reales en aleaciones de cinc-aluminio-magnesio

- Comparación de los recubrimientos tradicionales basados en cinc y las aleaciones basadas en cinc-aluminio-magnesio.

- Modelo de previsión del comportamiento a largo plazo de las aleaciones de cincaluminio-magnesio. Caso práctico. 


\begin{abstract}
In recent years, numerous types of surface corrosion coatings, based especially on zincaluminium-magnesium alloys (known as "ZM" alloys), have been developed as alternatives to traditional zinc-based coatings (known as "Z"), to improve its technical characteristics and reduce its cost. The manufacturers of these new treatments claim greater resistance to corrosion, based on accelerated corrosion tests and field tests, the latter lasting only a few years. The main objective of this thesis is the structuring and analysis of all the existing information in the current state of the art, and in particular, the study of the existing field tests to corroborate their resistance to corrosion in different types of environments and based on this, propose a mathematical model that facilitates its long-term calculation.
\end{abstract}

A review of the state of the art of metal coatings based on $\mathrm{ZM}$ alloys is presented, which covers their evolution over time, the different qualities and designations existing in the market, their structure and composition, international standards that regulate them and a detailed research on field tests in different locations around the world, having found tests of a maximum duration of 6 years.

From the analysis of these field tests, a methodology is proposed to verify the performance and evolution of the corrosion-time function in the different exposure environments, categorized through the international standard ISO 9223 (ISO, 2012), which calls them "corrosivity classes", and which range is from $\mathrm{C} 1$ (very low) to $\mathrm{CX}$ (extreme). This analysis has classified all the test results by material, corrosivity class and evolution over time.

In this way, each corrosivity class has been investigated in depth, through statistical analysis, with special emphasis on annual corrosion, measured as mass loss ( $\mu \mathrm{m} /$ year), the corrosion-time function and its adjustment to a certain behaviour. The $\mathrm{Z}$ coatings have also been analysed to be able to compare both alternatives and corroborate the main hypothesis, whose main assumption is the greater resistance to corrosion of $\mathrm{ZM}$ alloys compared to $\mathrm{Z}$ coatings. This analysis has been the entry point to establish a mathematical model that determines the long-term corrosion performance, to provide project engineering professionals, with a tool to estimate the corrosion resistance and optimize the cost of an installation when different types of materials are used. The summary of all this analysis has been reflected in the Results and discussion section.

The referred methodology has been applied to a case study to show how to select the quality of the coating and its optimal thickness, as well as a cost calculation, in order to guarantee the requirements of a specific project, in terms of resistance to corrosion and cost.

The final conclusions show that there are some advantages of ZM alloys over Z coatings, mainly with regard to corrosion resistance, having found relationships that can double and triple their performance, in the periods for which there are data available. In the same way, some disadvantages have been found, which must be investigated further in future research works, to give continuity to this thesis. For example, the limitation of these coatings to achieve large thicknesses, the limited duration of field tests, the performance of specific parts of the components (cuts, embossments, bends, welds ...), etc. Another point of attention is the few statistical data available, especially for the corrosivity categories C5 and CX, which makes it necessary to be cautious with the results obtained, although the calculation methodology is already established in this thesis, being ready to be supplemented when such data is available. 


\section{Resumen}

En los últimos años, se han desarrollado numerosos tipos de recubrimientos superficiales frente a la corrosión basados especialmente en aleaciones de cinc-aluminio-magnesio (conocidas como aleaciones "ZM"), como alternativas a los recubrimientos tradicionales basados en cinc (conocidos como "Z"), con el fin de mejorar sus características técnicas y reducir su coste. Los fabricantes de estos nuevos tratamientos reivindican una mayor resistencia a la corrosión, basándose en ensayos de corrosión acelerada y ensayos de campo, estos últimos de muy pocos años de duración. La presente tesis, tiene como principal objetivo la estructuración y análisis de toda la información existente en el actual estado de la técnica, y en particular, el estudio de los ensayos de campo existentes para corroborar su resistencia a la corrosión en distintos tipos de ambientes y a partir de ello, proponer un modelo matemático que facilite su cálculo a largo plazo.

Se presenta una revisión del estado de la técnica de recubrimientos metálicos basados en aleaciones ZM, que cubre su evolución en el tiempo, las diferentes calidades y designaciones existentes en el mercado, su estructura y composición, normas internacionales que los regulan y una detallada investigación sobre ensayos de campo en localizaciones de todo el mundo, habiéndose encontrado ensayos de una duración máxima de 6 años.

A partir del análisis de estos ensayos de campo, se propone una Metodología para verificar el rendimiento y la evolución de la función corrosión-tiempo, en los diferentes ambientes de exposición, categorizados a través de la norma internacional ISO 9223 (ISO, 2012), que los denomina "categorías de corrosividad", y que abarcan desde C1 (muy bajo) hasta CX (extremo). Este análisis ha clasificado todos los resultados de los ensayos por material, categoría de corrosividad y evolución a lo largo del tiempo.

De esta forma, cada categoría de corrosividad ha sido investigada en profundidad, mediante un análisis estadístico, poniendo especial énfasis en la corrosión anual, medida como pérdida de masa ( $\mu \mathrm{m} / \mathrm{año}$ ), la función corrosión-tiempo y su ajuste a un determinado comportamiento. Se han analizado asimismo los recubrimientos $\mathrm{Z}$ con el fin de poder comparar ambas alternativas y corroborar la hipótesis de partida, cuyo supuesto principal es la mayor resistencia a la corrosión de las aleaciones ZM frente a los recubrimientos Z. Este análisis ha sido el punto de entrada, para establecer un modelo matemático que determine el rendimiento de la corrosión a largo plazo, con el fin de proporcionar a los profesionales de proyectos en la ingeniería, una herramienta que permita estimar la resistencia a la corrosión y la optimización del coste de una instalación cuando se utilizan diferentes tipos de materiales. El compendio de todo este análisis se ha reflejado en el apartado de Resultados y comentarios.

La referida metodología, se ha aplicado a un caso de estudio para mostrar cómo seleccionar la calidad del recubrimiento y su espesor óptimo, así como un cálculo de costes, con el objetivo de garantizar los requisitos de un determinado proyecto, en términos de resistencia a la corrosión y coste.

Las conclusiones finales ponen de manifiesto que existen algunas ventajas de las aleaciones ZM frente a recubrimientos $Z$, principalmente en lo que respecta a la resistencia a la corrosión, al haber encontrado relaciones que pueden duplicar y triplicar su rendimiento, en los períodos para los que hay datos disponibles. Del mismo modo, se han encontrado algunas desventajas, que deben investigarse más a fondo en futuros trabajos de investigación, para dar continuidad a esta tesis. Por ejemplo, la limitación de estos recubrimientos para lograr grandes espesores, la limitada duración de los ensayos de campo, el rendimiento en partes específicas de los componentes (cortes, embuticiones, doblados, soldaduras...), etc. Otro punto de atención son los pocos datos estadísticos disponibles, en especial para las categorías de corrosividad C5 y CX, lo que hace que sea necesario ser cauteloso con los resultados obtenidos, aunque la metodología de cálculo ya quede establecida en esta tesis, estando lista para ser complementada cuando se tengan dichos datos disponibles. 


\section{Resum}

En els últims anys, s'han desenvolupat nombrosos tipus de recobriments superficials enfront de la corrosió basats especialment en aliatges de zinc-alumini-magnesi (conegudes com a aliatges "ZM"), com alternatives als recobriments tradicionals basats en zinc (coneguts com a "Z"), amb la finalitat de millorar les seues característiques tècniques i reduir el seu cost. Els fabricants d'aquests nous tractaments reivindiquen una major resistència a la corrosió, basant-se en assajos de corrosió accelerada i assajos de camp, aquests últims de molt pocs anys de duració. La present tesi, té com a principal objectiu l'estructuració i anàlisi de tota la informació existent en l'actual estat de la tècnica, i en particular, l'estudi dels assajos de camp existents per a corroborar la seua resistència a la corrosió en diferents tipus d'ambients i a partir d'això, proposar un model matemàtic que facilite el seu càlcul a llarg termini.

Es presenta una revisió de l'estat de la tècnica de recobriments metàl-lics basats en aliatges ZM, que cobreix la seua evolució en el temps, les diferents qualitats i designacions existents en el mercat, la seua estructura i composició, normes internacionals que els regulen i una detallada investigació sobre assajos de camp en localitzacions de tot el món, havent-se trobat assajos d'una duració màxima de 6 anys.

A partir de l'anàlisi d'aquests assajos de camp, es proposa una metodologia per a verificar el rendiment i l'evolució de la funció corrosió-temps, en els diferents ambients d'exposició, categoritzats a través de la norma internacional ISO 9223 (ISO, 2012), que els denomina "categories de corrosivitat", i que abasten des de C1 (molt baix) fins a CX (extrem). Aquesta anàlisi ha classificat tots els resultats dels assajos per material, categoria de corrosivitat i evolució al llarg del temps.

D'aquesta manera, cada categoria de corrosivitat ha sigut investigada en profunditat, mitjançant una anàlisi estadístic, posant especial èmfasi en la corrosió anual, mesura com a pèrdua de massa ( $\mu \mathrm{m} /$ any), la funció corrosió-temps i el seu ajust a un determinat comportament. S'han analitzat així mateix els recobriments Z amb la finalitat de poder comparar totes dues alternatives i corroborar la hipòtesi de partida, el supòsit principal de la qual és la major resistència a la corrosió dels aliatges ZM enfront dels recobriments Z. Aquesta anàlisi ha sigut el punt d'entrada, per a establir un model matemàtic que determine el rendiment de la corrosió a llarg termini, amb la finalitat de proporcionar als professionals de projectes en l'enginyeria, una eina que permeta estimar la resistència a la corrosió i l'optimització del cost d'una instal-lació quan s'utilitzen diferents tipus de materials. El compendi de tota aquesta anàlisi s'ha reflectit en l'apartat de Resultats i comentaris.

La referida metodologia, s'ha aplicat a un cas d'estudi per a mostrar com seleccionar la qualitat del recobriment i la seua grossària òptima, així com un càlcul de costos, amb l'objectiu de garantir els requisits d'un determinat projecte, en termes de resistència a la corrosió i cost.

Les conclusions finals posen de manifest que existeixen alguns avantatges dels aliatges ZM enfront de recobriments Z, principalment pel que fa a la resistència a la corrosió, en haver trobat relacions que poden duplicar i triplicar el seu rendiment, en els períodes per als quals hi ha dades disponibles. De la mateixa manera, s'han trobat alguns desavantatges, que han d'investigar-se més a fons en futurs treballs de recerca, per a donar continuïtat a aquesta tesi. Per exemple, la limitació d'aquests recobriments per a aconseguir grans espesors, la limitada duració dels assajos de camp, el rendiment en parts específiques dels components (talls, embuticions, doblegats, soldadures...), etc. Un altre punt d'atenció són les poques dades estadístiques disponibles, especialment per a les categories de corrosivitat C5 i CX, la qual cosa fa que siga necessari ser cautelós amb els resultats obtinguts, encara que la metodologia de càlcul ja quede establida en aquesta tesi, estant llesta per a ser complementada quan es tinguen aquestes dades disponibles. 


\section{GENERAL INDEX}

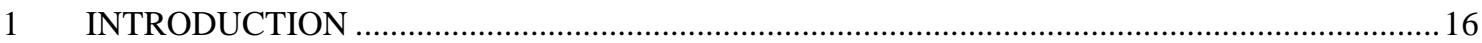

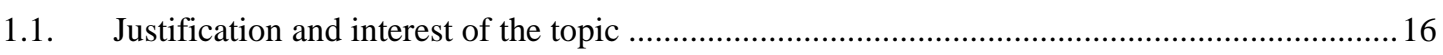

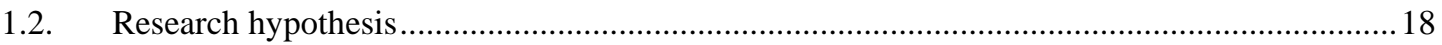

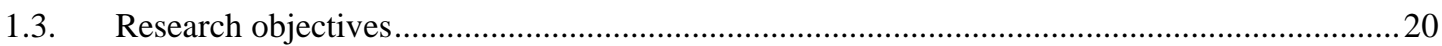

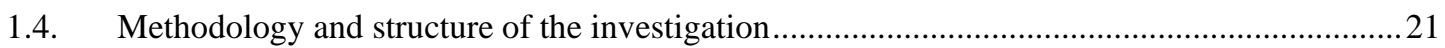

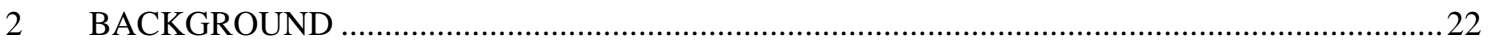

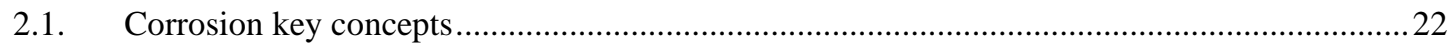

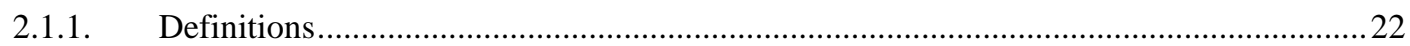

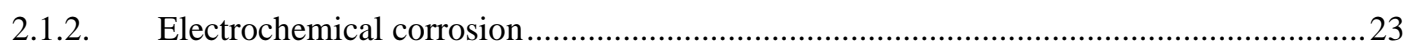

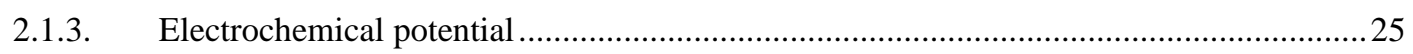

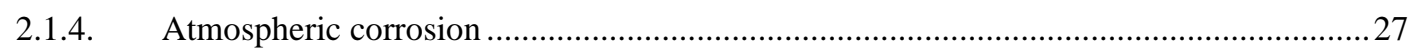

2.1.5. Influencing atmospheric pollutants in corrosion processes ….......................................28

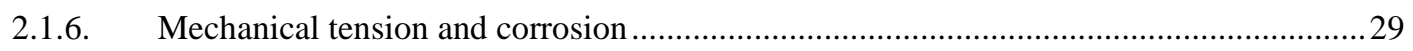

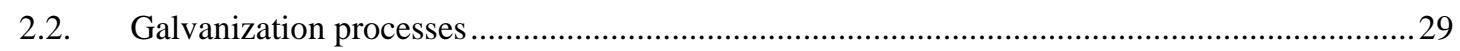

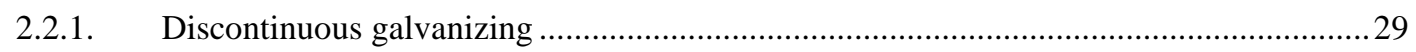

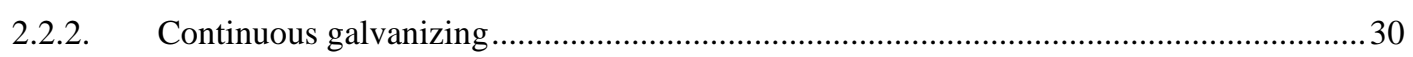

2.3. Long-term corrosion calculation on zinc-based coatings........................................................ 30

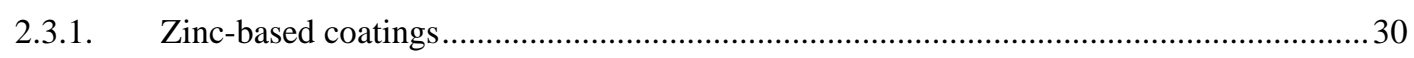

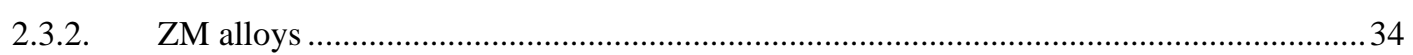

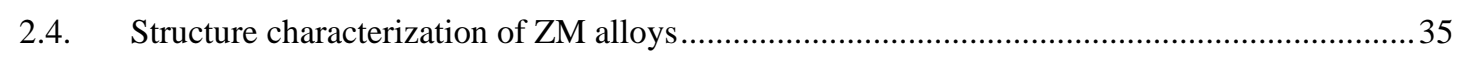

2.5. Corrosion behaviour and corrosion products characterization................................................... 36

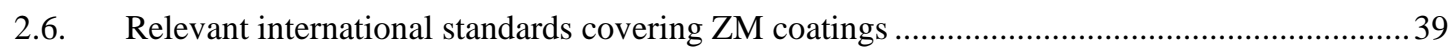

2.6.1. Standards to classify environments and corrosivity categories .........................................39

2.6.2. Standards to classify continuously hot-dip coated steel flat products for cold forming ... 42

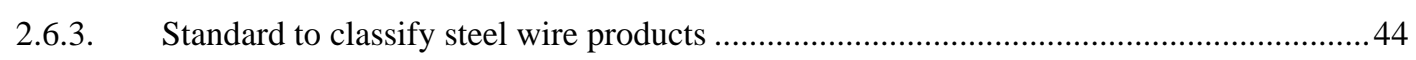

2.6.4. Differences between standards in terms of aluminium and magnesium content ................4 44

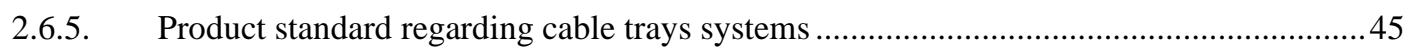

2.7. Environmental claims in Zinc-Aluminium-Magnesium alloys.................................................46

2.8. Zinc-Aluminium-Magnesium alloys offered in the market ....................................................... 47

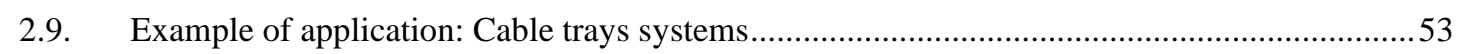

2.9.1. Brief Cable Tray systems introduction.........................................................................

2.9.2. Types of cable tray systems according to their metallic coating ......................................53

2.9.3. Cable trays system manufacturers using $\mathrm{ZM}$ alloys ........................................................... 55

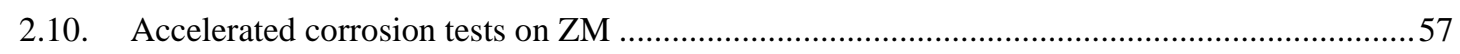

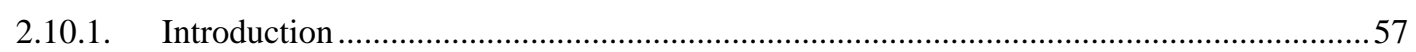

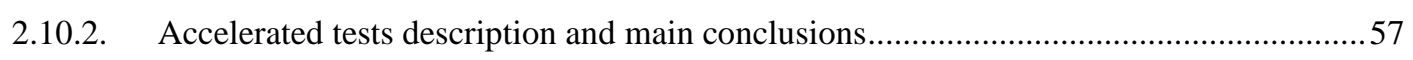

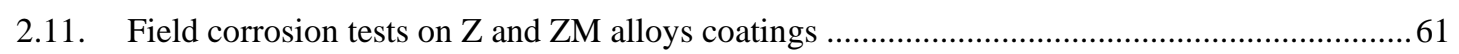

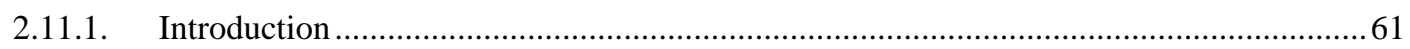

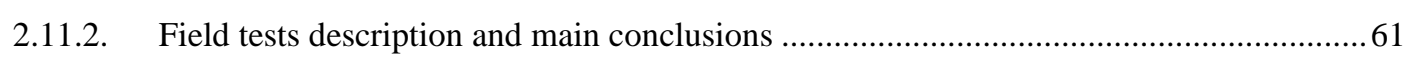




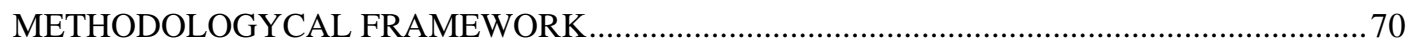

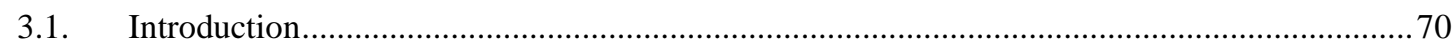

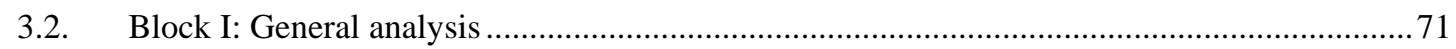

3.2.1. Classification of field tests results .......................................................................... 71

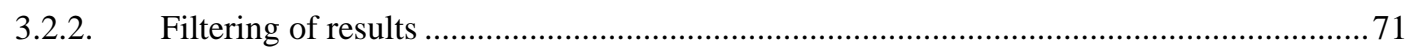

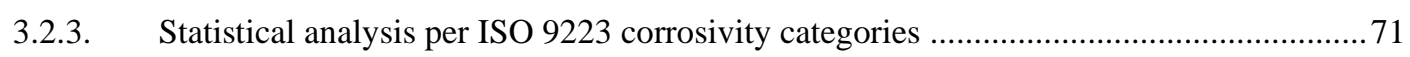

3.2.4. Average linear evolution of $\mathrm{Z}$ and $\mathrm{ZM}$ finishes ........................................................... 71

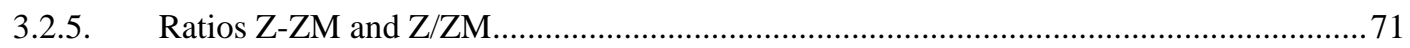

3.2.6. Behaviour of $\mathrm{ZM}$ during first year of exposure............................................................... 71

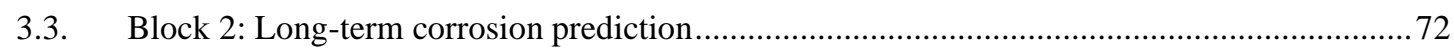

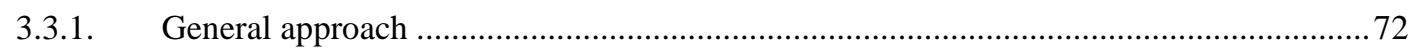

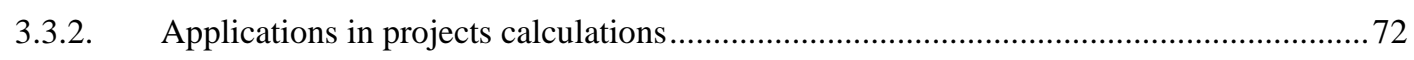

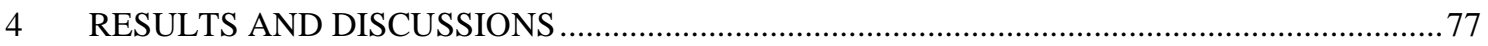

4.1. General view of results classified by year and corrosivity class ..............................................

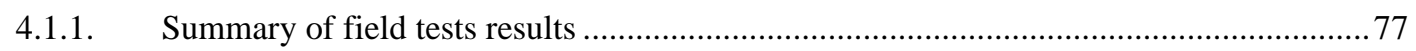

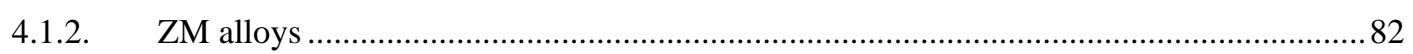

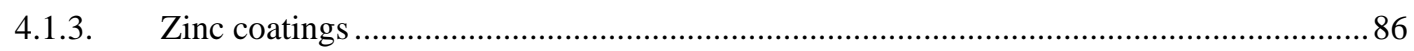

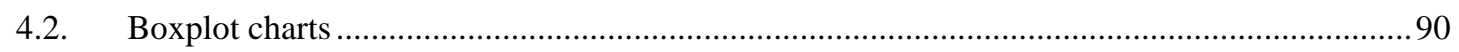

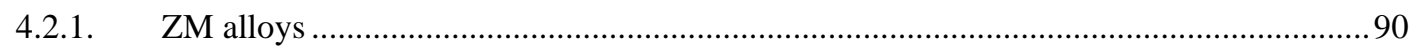

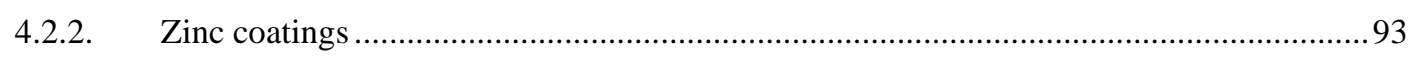

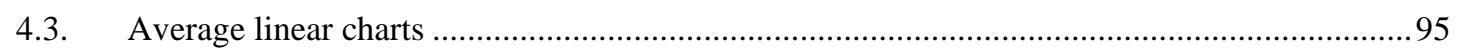

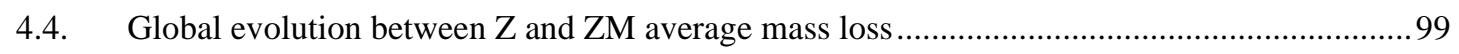

4.5. Ratios Z-ZM and Z/ZM evolution over the time ................................................................... 101

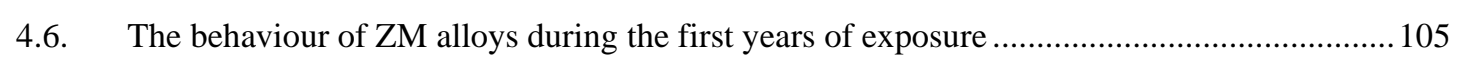

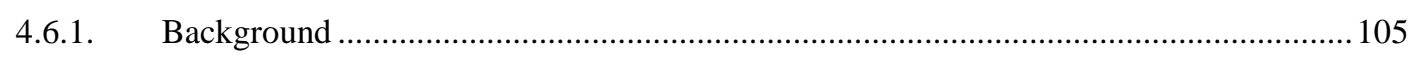

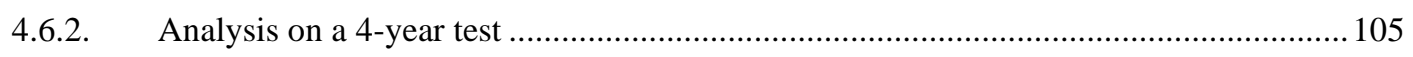

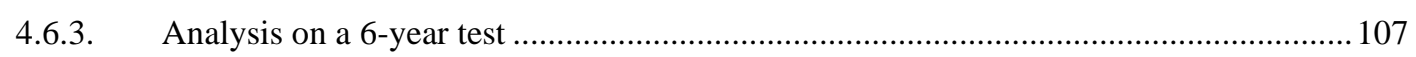

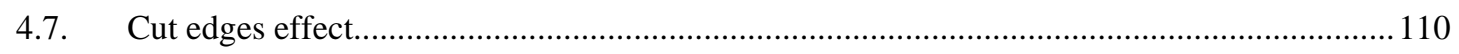

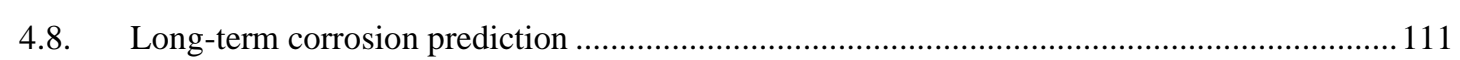

4.8.1. Corrosion prediction with the actual field tests values analysis .....................................111

4.8.2. Corrosion prediction using the general corrosion expression.......................................... 112

4.8.3. Application of long-term corrosion prediction to ZM alloys with general corrosion

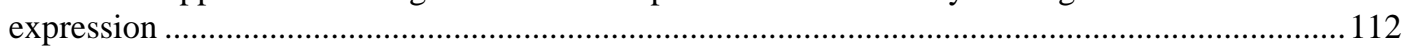

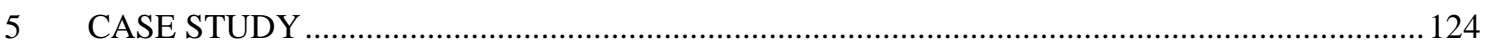

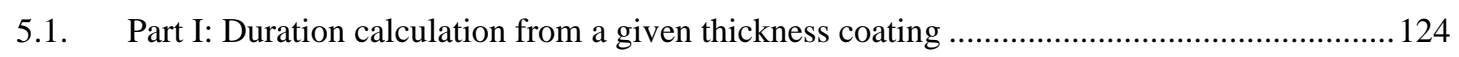

5.2. Part II: Corrosion calculation from a given exposition time ……………………………....... 126

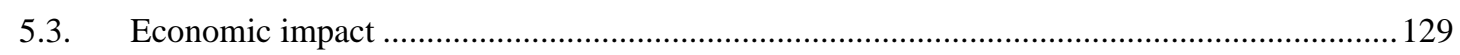

6 CONCLUSIONS, SYNTHESIS OF CONTRIBUTIONS AND FUTURE RESEARCHES ...........130

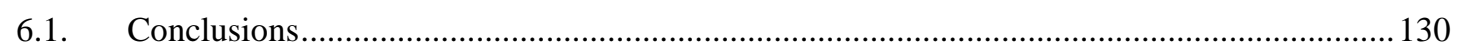

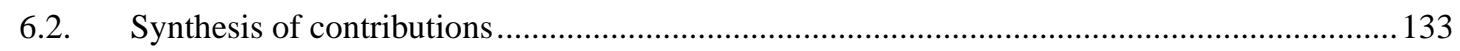

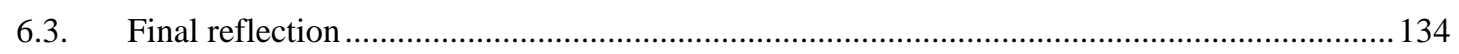


6.4. Future researches

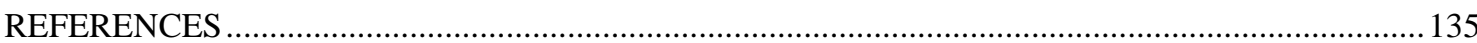




\section{INDEX OF FIGURES}

Figure 1: Corrosion resistance of Magnelis alloy in a cyclic test (Source: Arcelor Mittal public brochure Magnelis: Think strategy)......

Figure 2: Mass loss comparison between galvanized steel and zinc alloys (Source: Wheeling-Nisshin public ZAM brochure).

Figure 3: Comparison between Tata Corus Magizinc ${ }^{\circledR}$ and zinc coatings. Source: Tata Corus public

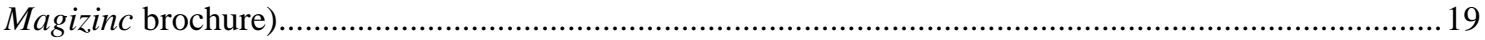

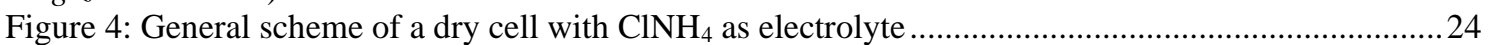

Figure 5: Diagram of the operation of an acid solution corrosion cell ..................................................25

Figure 6: Diagram of the operation of an aerated neutral solution corrosion cell ..................................25

Figure 7: Variation of ft, versus wetness time. Source: own illustration based on reference (Morcillo \&

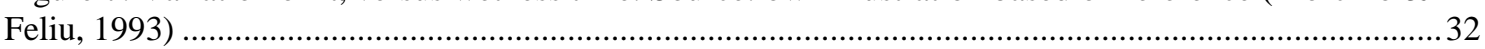

Figure 8: Variation of $\alpha$ versus mean values of $\mathrm{SO}_{2}$. Source: own illustration based on reference (Morcillo

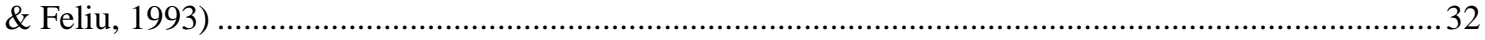
Figure 9: Variation of $\beta$ versus mean values of chlorides. Source: own illustration based on reference

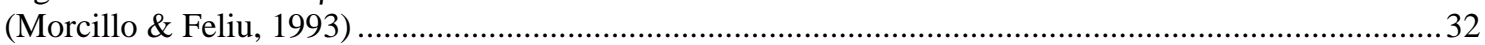

Figure 10: Corrosion evolution in ZM alloys for C2-CX corrosivity class ( $\mu \mathrm{m}$ vs years) .......................35 Figure 11: Characterization of the uncorroded Zn-Mg-Al coating: (a) General structure; (b) High resolution figure representing the detailed microstructure of the ternary eutectic..................................36

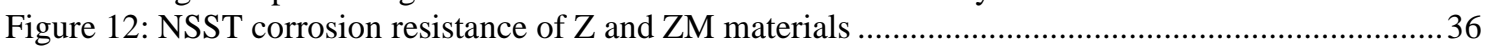

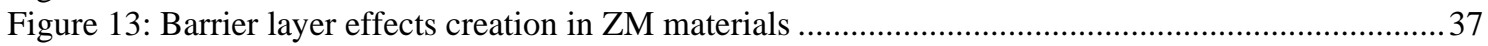

Figure 14: Aluminium content (\%) ranges according to the 3 main standards for ZM materials ...............44 Figure 15: Magnesium content (\%) ranges according to the 3 main standards for ZM materials .............45 Figure 16: Zinc runoff rate. Source: (Source: Arcelor Mittal public brochure Magnelis book) .................46 Figure 17: Production impact on $\mathrm{CO}_{2}$ emissions in Magnelis ${ }^{\circledR}$ production. (Source: Arcelor Mittal public

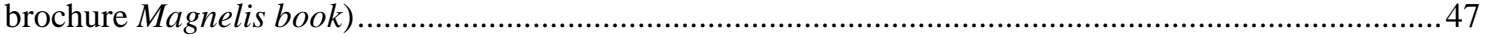
Figure 18: Evolution of metal alloys development in the European market .........................................47 Figure 19: Content of aluminium and magnesium offered by the main ZM suppliers ............................52 Figure 20: Sum of aluminium and magnesium content offered by the main ZM suppliers ....................52 Figure 21: NSST duration before red rust. \% represents the sum of $\mathrm{Al}+\mathrm{Mg}$ content ............................53 Figure 22: Example of pre-galvanized cable trays offer (Source: Pemsa Cable Management SAU - Spain.

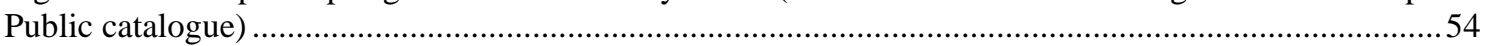
Figure 23: Example of white and yellow electroplated finish in mesh cable trays (Source: Schneider

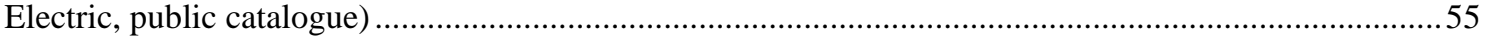

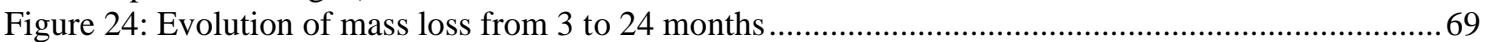
Figure 25: Methodology to choose the type of material. Part I: Duration calculation from a given

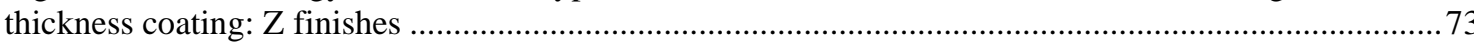
Figure 26: Methodology to choose the right material. Part I: Duration calculation from a given thickness

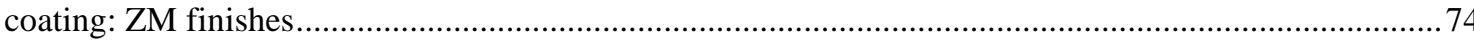

Figure 27: Methodology to choose the right material. Part II: Corrosion calculation from a given

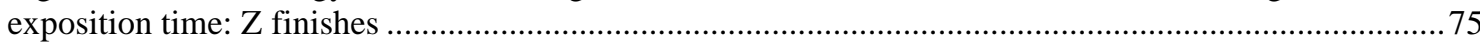

Figure 28: Methodology to choose the right material. Part II: Corrosion calculation from a given

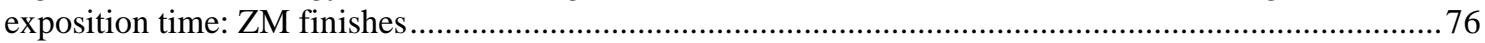

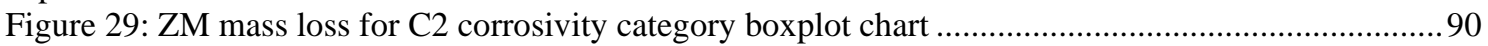

Figure 30: ZM mass loss for C3 corrosivity category boxplot chart ................................................. 91

Figure 31: ZM mass loss for C4 corrosivity category boxplot chart …........................................... 92

Figure 32: ZM mass loss for C5 corrosivity category boxplot chart ................................................. 92

Figure 33: ZM mass os for CX corrosivity category boxplot chart ..................................................93

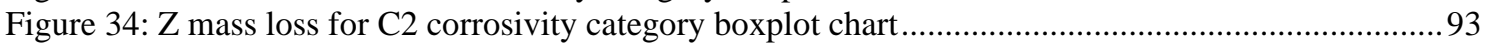

Figure 35: Z mass loss for C3 corrosivity category boxplot chart .....................................................94

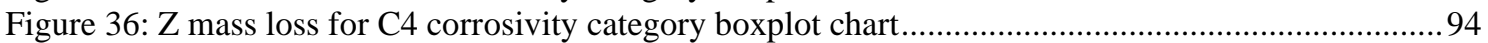

Figure 37: Z mass os for C5 corrosivity category boxplot chart ..................................................... 95

Figure 38: Z mass loss for CX corrosivity category boxplot chart ................................................95

Figure 39: Mass loss evolution over time for C2 corrosivity category .............................................96

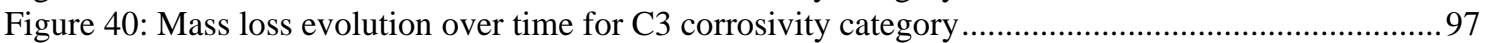

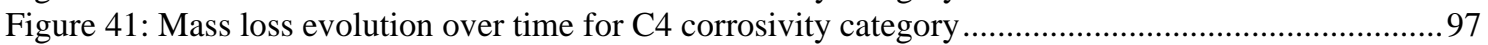

Figure 42: Mass loss evolution over time for C5 corrosivity category ..............................................98 
Figure 43: Mass loss evolution over time for CX corrosivity category …........................................98

Figure 44: Mass loss yearly average evolution for $\mathrm{Z}$ and $\mathrm{ZM}$ coatings ............................................ 100

Figure 45: Evolution of the average of Z-ZM ratio along corrosivity categories ................................. 102

Figure 46: Evolution of the average of Z/ZM ratio along corrosivity categories ................................. 103

Figure 47: Yearly evolution of Z-ZM and Z/ZM indicators by corrosivity category ........................... 104

Figure 48: Yearly evolution of Z/ZM general average ratio for 4-years exposure test ......................... 106

Figure 49: Yearly evolution of Z/ZM average ratio for 4-years exposure test - C2 corrosivity category 106

Figure 50: Yearly evolution of Z/ZM average ratio for 4-years exposure test - C3 corrosivity category 107

Figure 51: Yearly evolution of Z/ZM average ratio for 4-years exposure test - C4 corrosivity category 107

Figure 52: Yearly evolution of Z/ZM general average ratio for 6-years exposure test ......................... 109

Figure 53: Yearly evolution of Z/ZM average ratio for 6-years exposure test - C2 corrosivity category 109

Figure 54: Yearly evolution of Z/ZM average ratio for 6-years exposure test - C3 corrosivity category 110

Figure 55: Yearly evolution of Z/ZM average ratio for 6-years exposure test - C4 corrosivity category 110

Figure 56: Yearly mass loss graphic evolution in $\mathrm{C} 2$ corrosivity category for each of the calculated values

of $n$

115

Figure 57: Yearly mass loss graphic evolution in C3 corrosivity category for each of the calculated values

of $n$ .117

Figure 58: Yearly mass loss graphic evolution in C4 corrosivity category for each of the calculated values

of $n$

Figure 59: Yearly mass loss graphic evolution in C5 corrosivity category for the calculated value of $n .121$

Figure 60: Yearly mass loss graphic evolution in CX corrosivity category for the calculated value of $n 123$

Figure 61: Yearly mass loss graphic evolution for all corrosivity categories using the average of of $n$

values

Figure 62: Yearly mass loss graphic evolution for $\mathrm{C} 2, \mathrm{C} 3$ and $\mathrm{C} 4$ corrosivity categories using the average

of $n$ values 


\section{ÍNDEX OF TABLES}

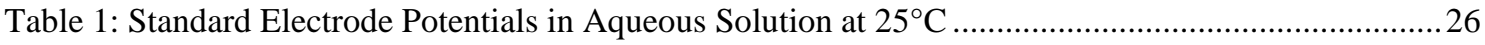

Table 2: Variables and parameters used in the methods to estimate annual corrosion (A) .......................... 31

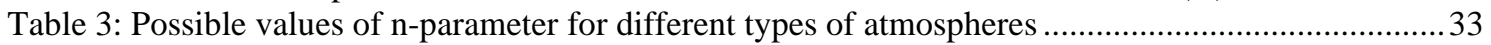

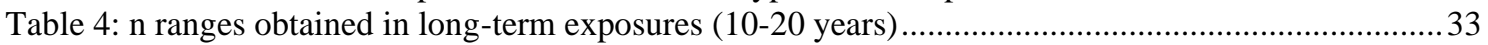

Table 5: n-parameter values for predicting and estimating zinc corrosion attack according to EN ISO 9224

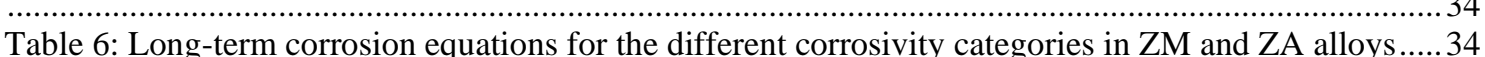

Table 7: Time to red rust appearance as a function of testing conditions in weeks.....................................38

Table 8: $24 \mathrm{~h}$ cycle time distribution in Volvo ${ }^{\circledR}$ test according to STD1027 ……................................... 38

Table 9: Corrosion results expressed in coating mass loss for each material tested by Galvazinc \& Cetim

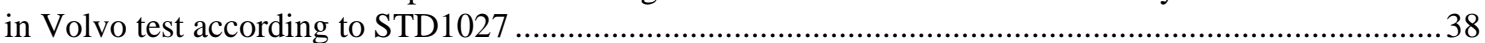

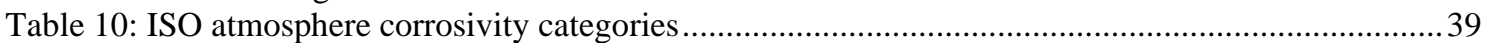

Table 11: Corrosion rates for zinc, $r_{c o r r}$, expressed in $\mu \mathrm{m} \cdot a^{-1}$ for the first year of exposure for the different

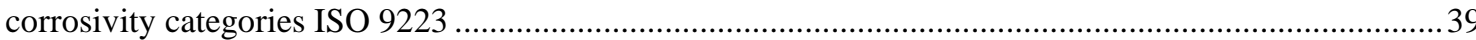

Table 12: Description of typical atmospheric environments related to the estimation of corrosivity categories (Source: ISO 9223).

Table 13: Time exponent values for predicting and estimating corrosion attack. Source: ISO 9224 (Table

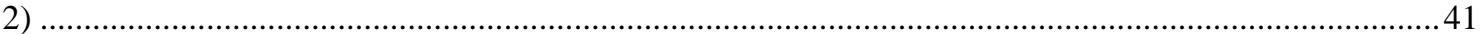

Table 14: Composition of zinc/aluminium/magnesium alloys according to EN 10346 ................................42

Table 15: Coating mass for Zinc (Z) and Zinc-magnesium alloy (ZM). Source: EN 10346 (Table 12) ....43

Table 16: Most relevant metallic alloys alternative to traditional zinc-based coatings ...............................4

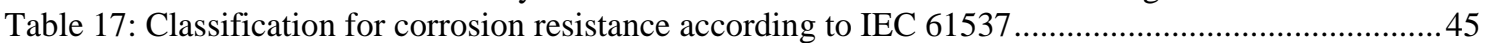

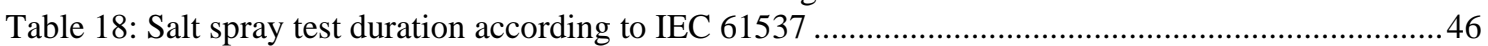

Table 19: Main alloys based on zinc-aluminium-magnesium products existing in the market and their corresponding manufacturers, used in electrical conduits ........................................................................ 48

Table 20: Minimum coating thickness and mass on samples that are not centrifuged (ISO 1461) .............54

Table 21: Examples of cable trays system manufacturers using ZM and ZA alloys (standard or wire cable

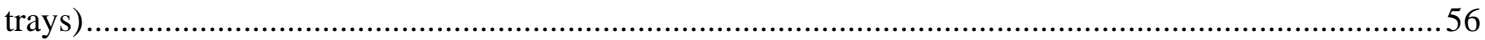

Table 22: Accelerated test \#1 summary and corrosion rate .....................................................................57

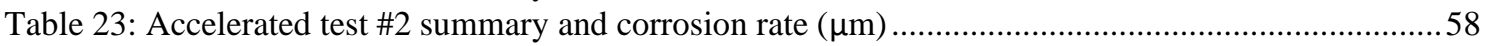

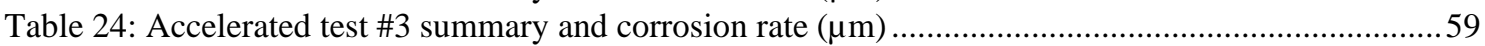

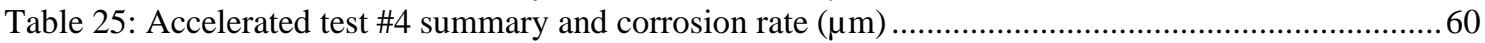

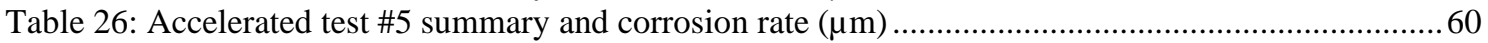

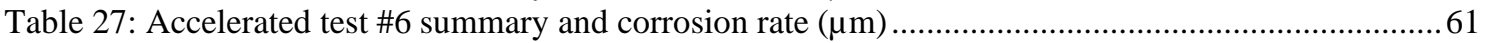

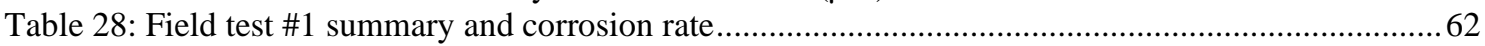

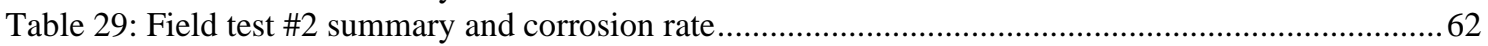

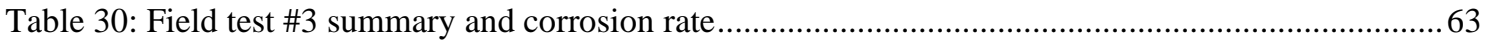

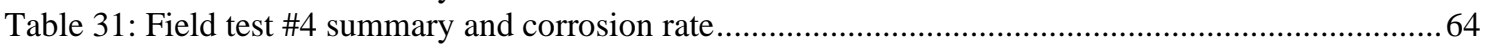

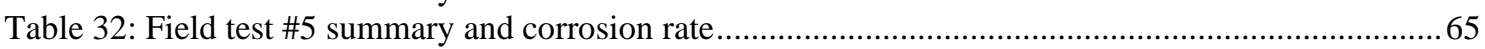

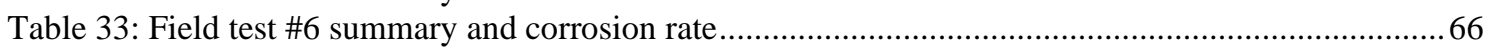

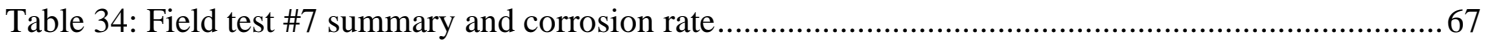

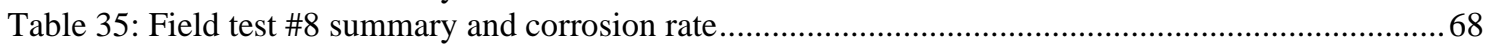

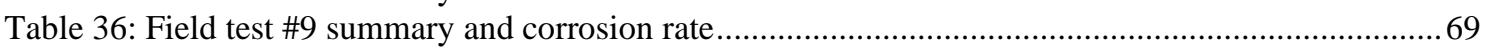

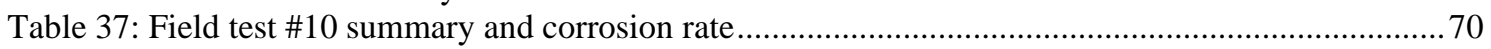

Table 38: Field tests results summary of the different research works analysed........................................78

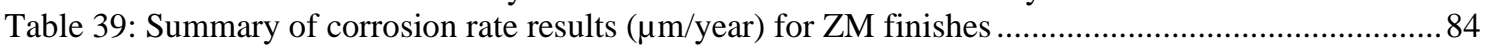

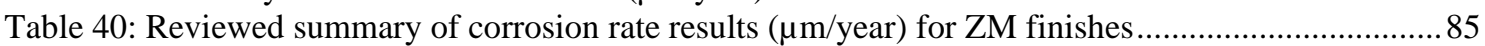

Table 41: Average, median and standard deviation from field tests for ZM finishes................................86

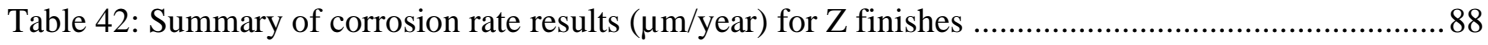

Table 43: Reviewed summary of corrosion rate results $(\mu \mathrm{m} / \mathrm{year})$ for $Z$ finishes ......................................8 89

Table 44: Average, median and standard deviation from field tests for $Z$ finishes ..................................90

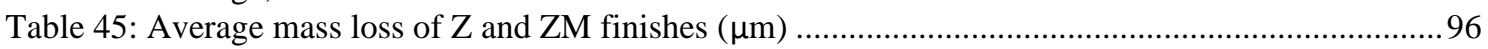

Table 46: Average, gap ZM-Z and ratio Z/ZM yearly evolution by corrosivity class...............................101

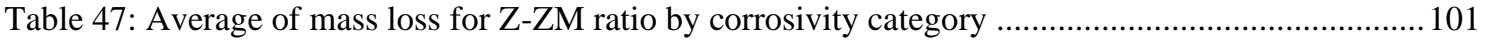

Table 48: Average of mass loss for Z/ZM ratio by corrosivity category .................................................102

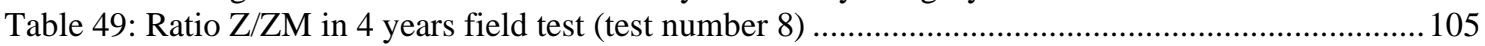


Table 50: 4 years tests field results (example for test number 8.1: Brest)

Table 51: Yearly evolution of Z/ZM average ratio for 4-years exposure test ..................................... 106

Table 52: Ratio Z/ZM in 6 years field test (test number 10) ............................................................ 107

Table 53: 6 years tests field results (test number 10.1: Brest) ........................................................... 108

Table 54: Yearly evolution of Z/ZM average ratio for 6 -years exposure test .................................... 108

Table 55: Corrosion parameters using logarithmic method. Forecasted values ................................... 113

Table 56: Yearly mass loss evolution in C2 corrosivity category for each of the calculated values of $n .114$

Table 57: Yearly mass loss evolution in C3 corrosivity category for each of the calculated values of $n .116$

Table 58: Yearly mass loss evolution in C4 corrosivity category for each of the calculated values of $n .118$

Table 59: Yearly mass loss evolution in C5 corrosivity category for the calculated value of $n$.............

Table 60: Yearly mass loss evolution in CX corrosivity category for the calculated value of $n \ldots \ldots \ldots \ldots . . .122$

Table 61: Case study - Part I: Calculated duration (years) for a 24 microns coating thickness for Z and

$\mathrm{ZM}$ finishes

Table 62: Case study - Part II: Calculated corrosion (microns) for a 20 years warranty for Z and ZM

finishes 


\section{ÍNDEX OF EQUATIONS}

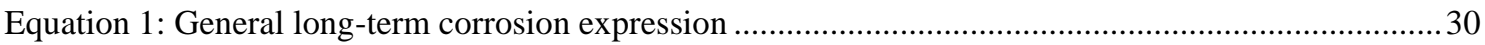

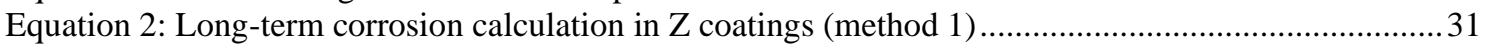

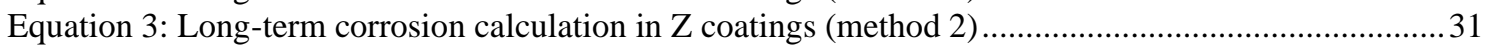

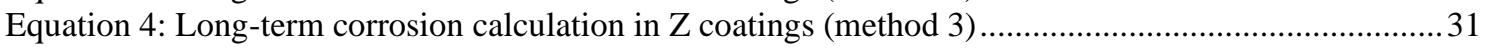

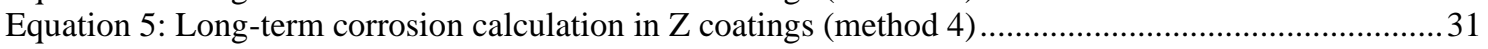

Equation 6: Calculation of fc coefficient in Method 4 calculation method ........................................... 31

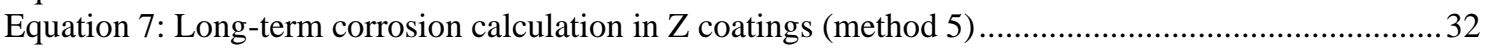

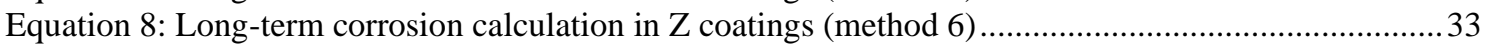

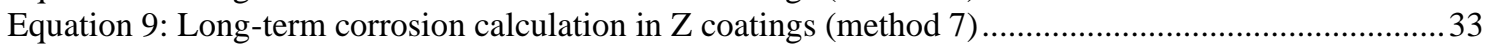

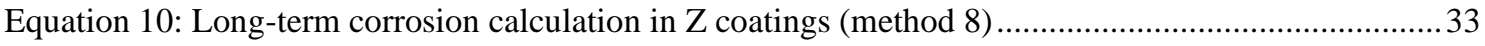

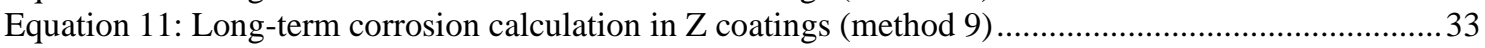

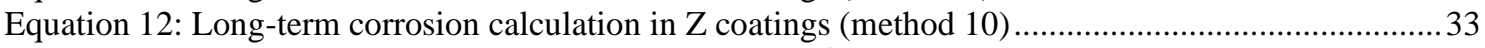

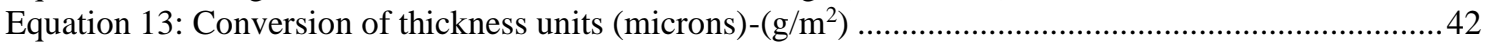

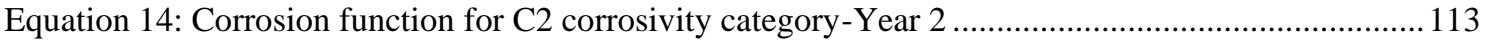

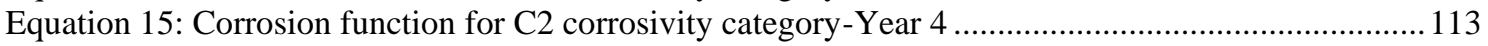

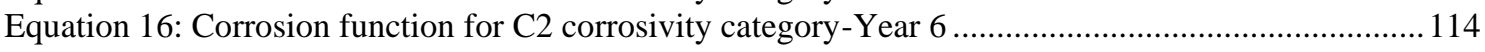

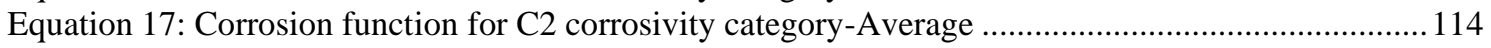

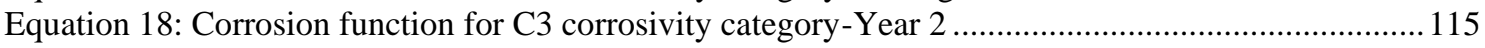

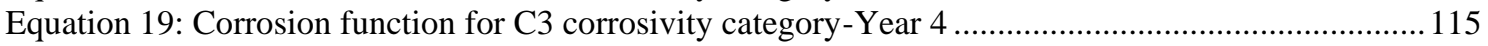

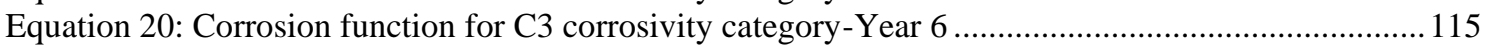

Equation 21: Corrosion function for C3 corrosivity category-Average ........................................... 115

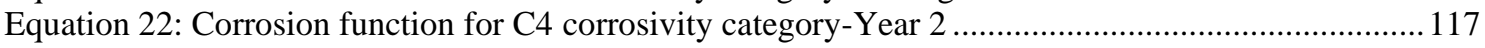

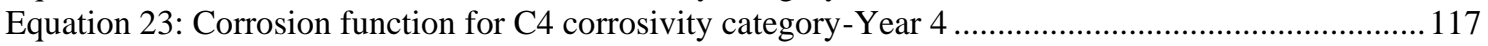

Equation 24: Corrosion function for C4 corrosivity category-Year 6 .............................................. 117

Equation 25: Corrosion function for C4 corrosivity category-Average …................................... 117

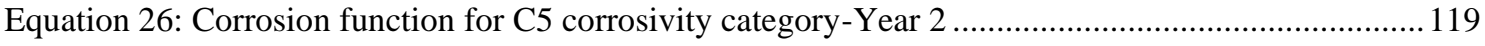

Equation 27: Corrosion function for CX corrosivity category-Year 2 ............................................ 121

Equation 28: Calculation of $t$ parameter from the general corrosion expression................................. 125 


\section{$1 \quad$ INTRODUCTION}

\subsection{Justification and interest of the topic}

One of the main problems that a designer faces when carrying out a specific project in an industrial plant, is determining the most appropriate type of metallic protective coating against corrosion, for all those parts which requires such protection. For instance, the electrical installation requiring a specific metallic trunking system to carry out the cable management. This type of installation requires the calculation, not only of the capacity area (dimensions of the trunking system and useful section thereof) and of mechanical resistance for the support of the conductors (load capacity in $\mathrm{kg} / \mathrm{m}$ of conduction), but also the necessary type of material and specific protective coating, to ensure resistance to environmental attack to that the electrical conduction is subjected during its use, and especially, to the so-called atmospheric corrosion.

This is just an example, but in the end corrosion in an industrial installation is fundamental factor that a project engineer must consider from the very beginning of the project. In these cases, corrosion is provocated by the combined action of the local environmental conditions where the industrial plant is located (atmospheric corrosion) and its internal environment, derived from the corresponding industrial processes.

For those reasons, the right choice of the type of coating in all those parts susceptible to attacks by the effect of corrosion, is a key subject in the specification of a given project, so to ensure the prescribed cost, warranty period and many times, the aesthetical appearance.

The continuous maintenance of a given installation from corrosion point of view is almost impossible; that's why it is very important to analyse very carefully, the type of material and coating to use, so to provide the lifetime protection from corrosion point of view, in the place where the installation will be located (BEAMA, 2012).

There are a large number of examples and antecedents of industrial installations, in which the selection process of the metallic materials, did not take into account the harmful effects of corrosion, resulting from an error, in selecting the most suitable type of material or the adequate thickness to ensure the installation warranty period.

In this sense, the market provides several types of coatings to alleviate the action of corrosion in different industrial environments. The most popular and most used are those based on zinc. Those solutions will be seen in detail in the background clause. Zinc-based coatings have been largely used, and according to the galvanization manufacturers, there are several reasons that makes these types of coating ideal for corrosion protection (Association, 2020; Galvanización, 2020):

a) Very long duration. An 80-micron thick galvanized coating can last up to 100 years in a rural environment, 40 to 100 years in an urban environment, 20 to 40 years in an industrial environment, and 10 to 20 years in a marine environment.

b) Zero maintenance. Galvanized coatings are maintenance free.

c) Very cheap. The initial cost of galvanizing is very reasonable, and in the long run, due to the lack of maintenance of galvanized coatings, it is cheaper than painting (the cost of labour is far from low).

d) Tremendously versatile. Can be galvanized from small parts such as nails and screws, to large structural elements.

e) Absolutely reliable. Hot dip galvanizing is a simple, controlled process and perfectly specified by international standards.

f) High resistance. Hot galvanizing the steel produces a zinc metallurgical coating that is highly resistant to shock and abrasion. It blocks the damages that produce damages and scratches, unlike other types of coatings, in which the accelerated oxidation of the steel would take place.

g) Compatible with everything. can be painted and combines very well with concrete, stainless steel and aluminium.

h) Totally manageable. In addition to painting, it can also be welded. the use of galvanized screwed or welded structures reduces the construction time

However, in the last years, several types of alloy coatings have been developed, in order to improve the performance of the traditional zinc-based metallic coatings, so as to have a better corrosion resistance while reducing the cost, thanks to the reduction of the total mass of the coating per unit of surface. Some authors 
already anticipated this evolution like CSIC in Spain: "It can be considered that zinc as anodic material has practically reached its limit of development, being currently displaced gradually by aluminium alloys of equal current efficiency (90\%), but with the advantage of having a greater real current supply ... and best electrochemical equivalent" (González Fernández, 1984).

These alloys are produced on a continuous hot dip galvanising line which molten bath has a chemical composition of zinc, Aluminium and/or Magnesium, even the last advances in this technology include the 3 components, performing an alloy composed by Aluminium, magnesium and the correspondent balance zinc. For instance, one of the main brands, Magnelis ${ }^{\circledR}$ (Arcelor Mittal, 2013e, 2017, 2018; R\&D, 2015), manufactured by Arcelor Mittal ${ }^{\circledR}$, has a specific composition of 3\% Magnesium, 3,5\% aluminium and the balance zinc (93,5\%). These specific alloys composition are recognized under the acronym of ZM alloys, according to EN 10346 (see Table 14: Composition of zinc/aluminium/magnesium alloys according to EN 10346) and it will be the way in which they will be called in this thesis, while traditional continuous hot dip galvanising made in zinc, is designated by the same standard by $Z$ coatings, that also will be used in this thesis to reference it.

ZM manufacturers recommend this type of alloys in applications where traditionally, zinc-based coating protection was used, with high thicknesses coating (post-galvanized) to be able to withstand corrosion effects in a harsh environment (road/civil engineering, housing, farming, construction, rail-roads, electric power and equipment, automobile parts, etc.), and in electric equipment such as metallic cable trays and trunkings for cable routing.

Other arguments for this alternative have been claimed, like:

- Better energy efficiency in the production

- Aesthetics (when compared with Hot Dip Galvanized process)

- Better self-healing protection in cuts and hem flanges

- Free of sharp edges, which they consider and advantage from a safety point of view in front of typical cutting edges of traditional hot-dip galvanizing coating.

- Better performance in sodium chloride-containing atmospheres, with high humidity or high condensation of water. In open panels, the corrosion rate can be up to $65 \%$ lower than for a pregalvanized finish

In front of the commercialization of these finishes, zinc coatings galvanizers claim points like:

- In acid atmospheres or with other type of pollutants (urban or industrial areas) the performance of ZM alloys is less relevant. This is for instance the case of traffic tunnels, where there's a high component of pollutants coming from vehicle combustion.

- The performance of ZM finishes decreases in hem flanges for all type of environments because of the affection of the bending process to its chemical structure. This has to be considered when choosing the type of metallic accessories to use, for instance in an electrical installation.

- On cut edges, self-healing phenomenon is occurring even in environments presenting very low chloride content, and in some cases for high steel thicknesses up to $5 \mathrm{~mm}$ in NSST. However, on rural environments, chloride-free environments, the self-healing phenomenon could be only observed in thinnest steel gauges. Thus, especial attention has to be payed when having parts with cut edges.

- Alloys with a high aluminium content (above 15\%), only provide effective cathodic protection against corrosion, in atmospheres with a high concentration level of chlorine ions, while alloys with high zinc content, the cathodic protection acts from the beginning in all cases.

- In general, the annual corrosion rate of the second and subsequent years is lower, due to the effect of the corrosion products. That's very important to be considered in the maintenance works. Also, in places where this corrosion products would be removed (for instance in rainy places), it has to be considered that corrosion resistance will be lower than in dry environments.

- At the time of choosing the right type of coating, it is very important to consider, not only the corrosion resistance rate, but also the thickness. For instance, even ZM alloys for specific environments have better corrosion rates, the current commercialized materials only offer thicknesses up to 32 microns $\left(430 \mathrm{~g} / \mathrm{m}^{2}\right)(\mathrm{CEN}, 2015)$. In the end, it is up to the project engineer to make calculations, according to the expected life duration of the installation and the corrosion rate, to properly choose the type of coating and its thickness.

- Traditional zinc-based coatings have a better performance in low $\mathrm{CO}_{2}$ content atmospheres. 
At present, there's a large amount of scattered information around this type of alloys, such as specific international normative, qualities and designations for purchasing purposes, many types of corrosion tests (field tests and accelerated tests), as well as large numbers of manufacturers and types of end users.

Thus, part of the aim of this thesis is to gather, classify and structure all this scattered information in order to facilitate engineers and other users, a complete summarized review of all the key aspects of these alloys. At the same time, a dedicated analysis has been done about long-term corrosion resistance, since at present, there is no specific guideline which provides all the findings of the actual corrosion tests or values of reference to determine the right thickness of the coating for a specific application.

\subsection{Research hypothesis}

Nowadays, there is an important controversial between traditional zinc coated products and the new alternative alloys. This controversy is caused by the fact that the manufacturers of the new alloys claim that they are not only an alternative to traditional zinc-based coatings, but also an improvement, in the sense that resistance to corrosion is greater, or what is the same, that the loss of mass because of corrosion process is less for a given type of environment. A summary of the main features claimed by these manufacturers is listed below:

- Corrosion resistance is longer than standard galvanised products and it outperforms coatings containing less magnesium. Arcelor Mittal ${ }^{\circledR}$ (Arcelor Mittal, 2017) argues this statement in his brochures based on the performance of cyclical corrosion tests, such as the one shown in Figure 1:

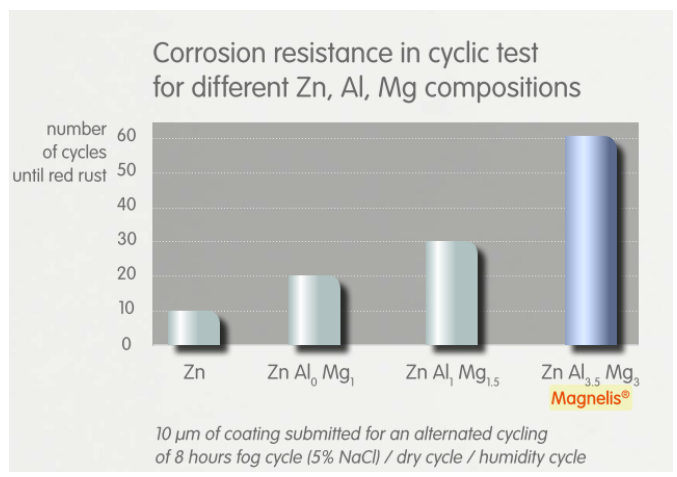

Figure 1: Corrosion resistance of Magnelis alloy in a cyclic test (Source: Arcelor Mittal public brochure Magnelis: Think strategy)

Other American company, Wheeling Nisshin ${ }^{\circledR}$ (Nisshin, 2015; Nisshin Wheeling, n.d.; Stramit, 2012) states in the same sense, that its brand for zinc/aluminium/magnesium alloy, $Z A M^{\circledR}$, has superior corrosion resistance as compared to galvanized steel, 55\% Al-Zn alloy coated steel and $\mathrm{Zn}-5 \% \mathrm{Al}$ alloy coated steel (see Figure 2). They also claim for instance, that it has superior corrosion resistance in ammonia environment (ammonia solution concentrate at 5\% (pH 12.5)). 


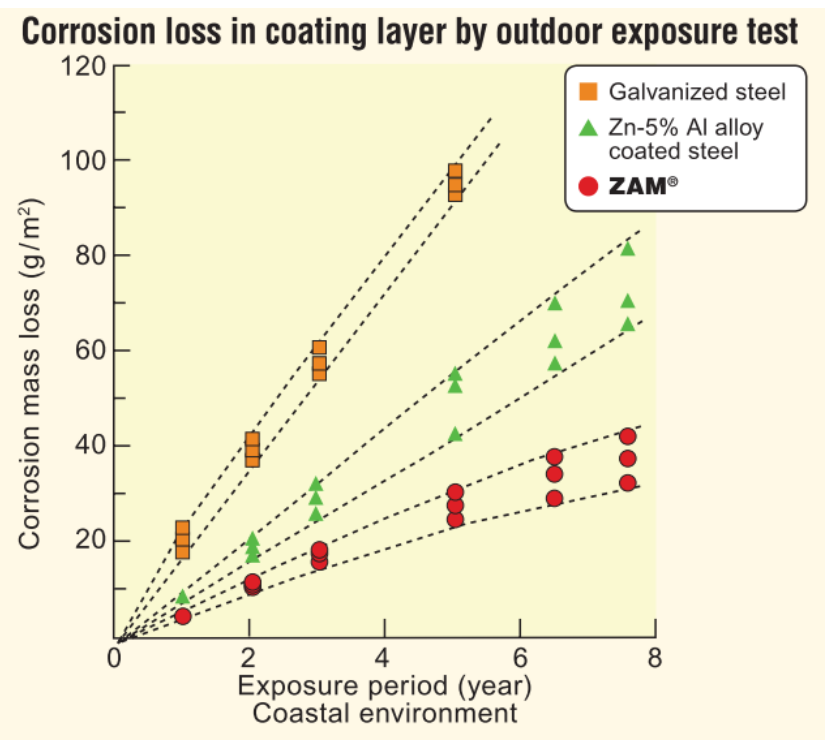

Figure 2: Mass loss comparison between galvanized steel and zinc alloys (Source: Wheeling-Nisshin public ZAM brochure)

The company Tata steel ${ }^{\circledR}$ (Tata Corus, 2010, 2012, 2016) also claims similar features with its brand Magizinc $^{\circledR}$, stating that it is an innovative replacement for conventional galvanised steels; it provides superior corrosion protection even in harsh environments (see Figure 3). Its unique formulation means that MagiZinc $®$ outperforms the protection of conventional galvanised steel. Suitable for a wide range of indoor and outdoor applications, it can be used to reduce coating weight or extend product life. This means less use of valuable resources and reduced environmental impact.

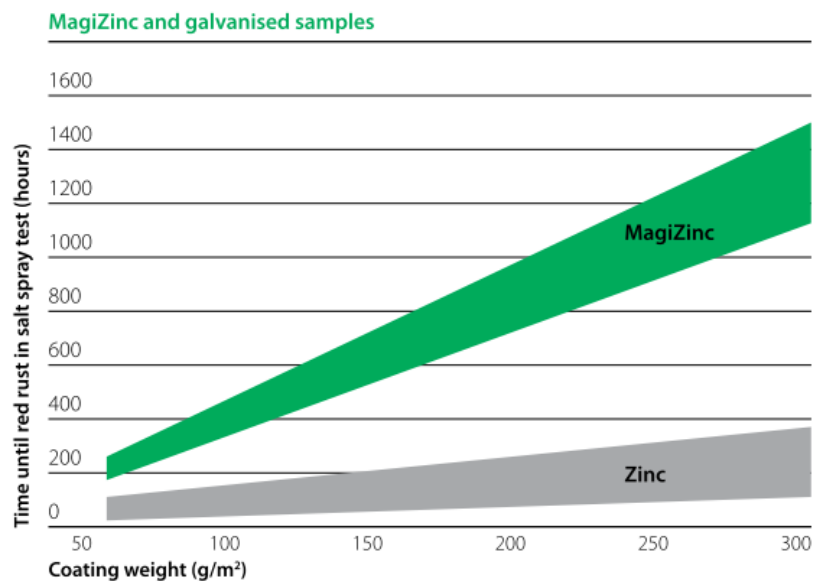

Figure 3: Comparison between Tata Corus Magizinc ${ }^{\circledR}$ and zinc coatings. Source: Tata Corus public Magizinc brochure)

Same or similar messages are given by the rest of these new alloys' manufacturers. Each of them can be found in Table 19: Main alloys based on zinc-aluminium-magnesium products existing in the market and their corresponding manufacturers, used in electrical conduits:

- Corrosion resistance, proven outdoors, through different field tests, being exposed to a variety of different environments around the world in outdoor tests. In this sense, manufacturers claim that this type of alloys withstand corrosion even 3 times more than traditional zinc-based coatings.

- Cost advantages. Obviously, this is a consequence of the better corrosion resistance, in the sense that, to warranty the same duration of a given installation, it will be needed less coating mass per unit of surface. From another point of view, for the same thickness of coating, its duration will be 
longer, and therefore, its warranty. In their brochures, Arcelor Mittal claims the lower weight of Magnelis $^{\circledR}$ coating to obtain the same level of corrosion resistance, the shorten logistics chain thanks to simpler fabrication processes, the high level of corrosion resistance of stainless and aluminium at a significantly lower cost, avoiding the need for post-painting that leads to cost savings and productivity improvement, the reduction of maintenance tasks, etc.

There is, in turn, another important point that due to the few years that these new alloys have been on the market, compared to traditional zinc-based coatings, they do not have a clear answer today. This is the forecast of long-term corrosion of these coatings. Due the long time that zinc-based coatings are in the market, there is a big deal of information to forecast long-term corrosion resistance of these coatings. Actually, the standards of the series ISO 922x (CEN (European Committee for Standardization), 2012; CEN, 2012; ISO (International Organization for Standardization), 2012a; ISO, 2012) provides guidelines to foresee this long-term corrosion by corrosivity category, as it will be deeply developed in this thesis.

Thus, based in all this previous introduction, this thesis intends to demonstrate the following hypotheses, based on both, the manufacturers 'claims for the aforementioned new alloys and the galvanizers claims for traditional zinc-based coatings:

- Hypothesis 1: Corrosion performance

The feature claimed by the ZM manufacturers, about the better performance in corrosion in front of traditional zinc-based coatings, for which there is a big deal of information and tests, most of them, but not all, arranged by these manufacturers. In this respect, the thesis will be focussed in the flat parts of the metallic pieces, and not in other type of mechanical conformation that shall be part of a separate research study, as will be referred during the development of this thesis. On the other hand, since the aim of the thesis is to contribute to the engineering projects discipline, to choose the right type of coating to warranty prescription in terms of corrosion resistance, the thesis will be focussed on real tests and applications, so to have a direct and quick answer for today's real applications.

- Hypothesis 2: Long-term corrosion behaviour

It has been proven, as it will be seen in the background part of this thesis, that the corrosion process in most of the metals obeys to a logarithmic law, included zinc. Even ZM alloys are composed of around $90 \%$ of this metal, it will be necessary to know if this logarithmic law is also applicable to these types of alloys. Based in the findings of this thesis in this respect, a specific model to determine long-term corrosion resistance of these new alloys will be proposed, based in the hypothesis of this logarithmic behaviour.

- Hypothesis 3: Ratio Z/ZM of mass loss performance over time

According to some galvanizer's association, the performance of ZM in front of Z, measured as this ratio, decreases along time, because the effect of the alloy is supposed to lessen over time. This way, this ratio would tend to 1 .

- Hypothesis 4: Optimization of coating selection process

An adequate selection method applied to the Design Project will allow optimizing the type of coating to be chosen, from the point of view of resistance to corrosion (compliance with the durability warranty) and from the economic point of view (overqualified materials), when prescribing coatings with a coating layer bigger than necessary or in the case of the same layer, a coating with greater resistance to corrosion.

\subsection{Research objectives}

In order to check the hypothesis described in previous clauses, the objectives of the research will be:

- Analysis of the chemical structure characterization of the ZM alloys to have a good understanding and what is the real difference in front to zinc coatings.

- The mechanism of the corrosion behaviour in order to understand in which way the news alloys behaves and the key difference in front to zinc coatings. 
- To gather all the technical information in terms of standards and standard designations, as well, as chemical compositions.

- Commercial offer of ZM alloys, main differences, main manufacturers and key differences among them.

- Analysis of cable tray systems manufacturers with a specific offer of ZM finishes in their metallic offer, since this specific industrial field, will be the one to use in the case analysis. Investigate how they correlate corrosion performance with zinc coatings.

- Search of field corrosion tests for ZM finishes and ideally, combined with traditional zinc-based coatings, so to have real results in terms of performance, despite the little experience had or the little number of tests as well as its duration. In this sense, there is a big deal of information in terms of accelerated corrosion tests, either with traditional neutral salt spray tests (NSTT) or with cyclic combined tests, which are closer to the corrosion behaviour in real field tests.

- Once collected all the referred field tests, a deep analysis will be arranged about the corrosion performance with a previous classification by each of the environments, using for this purpose the classification established in ISO 9223 standard (ISO, 2012). This analysis intends to bring to the project engineer a guideline of what the duration of the coating will be, based in the location where the installations is intended to be installed. Also, a statistical analysis will be done to evaluate as well, the level of error of the calculations.

- Once had all the results of corrosion classified by years and corrosivity categories, it will be proposed a methodology to have an estimation of the long-term corrosion behaviour. Contrary to what happens with zinc coatings, for the case of ZM alloys there is very little information about the long-term behaviour of these new alloys. One of the key objectives of this investigation will be to analyse the existing data of corrosion for the field tests done so far, look at the trend they follow, and design a mathematical model to simulate its long-term behaviour, besides the levels of error and uncertainty.

- Check the referred methodology with a specific case study, in this case, its application to the electrical part of an industrial project, in regard to the selection of the metallic electric cable tray system.

\subsection{Methodology and structure of the investigation}

Before arranging with the methodology itself, a previous analysis of the following topics will be done, inside the scope of the clause background:

- understanding of the chemical structure characterization

- mechanism of the corrosion behaviour, technical information in terms of standards

- standard designations

- analysis of commercial offers of ZM alloys manufacturers

- analysis of commercial offer of cable trays systems manufacturers

- $\quad$ field tests

Once analysed all these key objectives of the thesis, the methodology will focus on the analysis of the actual field tests. This methodology will have these key steps:

a) Collect all the field tests values and classified them by:

- Type of coating: zinc, whatever the treatment method used (pre-galvanized, postgalvanized, electrogalvanized...) and ZM.

- Corrosion by year. Corrosion will be measured in either, $\mathrm{g} / \mathrm{m}^{2}$ or $\mu \mathrm{m}$.

- Corrosivity category $(\mathrm{C} 1, \mathrm{C} 2, \mathrm{C} 3, \mathrm{C} 4, \mathrm{C} 5$ and $\mathrm{CX})$, using the methodology given in ISO 9223 (ISO, 2012), that is based in classified within these categories through the level of corrosion of zinc for year 1 . 
b) Statistical analysis: Calculation, for each corrosivity category, of the mean, standard deviation, median, boxplot charts, etc.

c) Graphical representation of the average corrosion evolution over time.

d) Analysis of the corrosion gap between ZM and Z finishes through: (1) Z-ZM difference; (2) ratio Z/ZM. This part will be key in order to corroborate Hypothesis 3, by giving clear figures about these 2 ratios, that will clearly reveal in a quantitative way these differences.

e) There are studies promoted by the different galvanizers associations, in which they claim that the effect of the magnesium / aluminium effect passes along the years, and the trend is to reach the same corrosion rate after a few years of exposure. This specific study will be part of this methodology in order to confirm or to discard this claim.

f) Up to this point of the methodology, it will be ready the values of corrosion based in the field tests analysed. Obviously, the longer the duration of the tests, the longer forecast of corrosion in time. At this point, Hypothesis 1 based on the claims of the manufacturers of ZM alloys, as regards their resistance to corrosion, and especially when compared with current zinc coatings, can now be corroborated.

g) Long-term corrosion forecast. This is an important added value of this research work, so make the best of the previous results of the investigation. The objective is to bring to designers, engineers and other project professionals a tool that facilitates an estimation of the durability of these new alloys in a specific environment, which also brings the possibility of optimizing the cost of the installation by either, selecting the right thickness of the coating or, extending the warranty period thanks to the longer duration of these coatings.

h) Case study. It will be shown a specific case of application of the referred methodology, applied to the selection of the right material of a metallic cable tray for a wiring electrical installation, in which it will be showed the importance of making the right choice not only for technical reasons, but for cost reasons.

\section{BACKGROUND}

\subsection{Corrosion key concepts}

\subsubsection{Definitions}

- "Corrosion": Physicochemical interaction between a metal and its environment which results in changes in the properties of the metal, and which may often lead to impairment of the function of the metal, the environment, or the technical system of which these form a part. Note: This interaction is often of an electrochemical nature (CEN (European Committee for Standardization), 2017; ISO, 2020)

- "Corrosion": Reaction of a metal or alloy with the medium with deterioration of the metallic properties. Due to this phenomenon, metals lose their elemental state and return to the combined state of origin. In chemical terms, the metallic atom is transformed into an ion, yielding its electrons to a nonmetal (oxygen, sulphur, etc.) (González Fernández, 1984)

- "Corrosion": Destructive attack of a metal by chemical or electrochemical reaction with its environment. Damage caused by physical means is not called corrosion, but rather erosion, abrasion or wear [...] The term "rusted" or "oxidation" is applied to the corrosion of iron and alloys in which it is the base metal; In this process, corrosion products are formed, mostly composed of hydrated iron oxides. Therefore, non-ferrous metals corrode but do not rust (Uhlig, 1979)

- "Metallic corrosion": Metal corrosion is surface wear that occurs when metals are exposed to reactive environments. The chemical compounds that constitute the products of such wear are close relatives of the metal-bearing mineral rocks found in the Earth's crust. In other words, corrosion reactions cause metals to return to their original ores (West, 1986) 
- "Atmosphere": A mixture of gases and normally also aerosols and particles, that surrounds a given object (CEN (European Committee for Standardization), 2017).

- "Type of atmosphere": Characterization of the atmosphere on the basis of appropriate classification criteria other than corrosivity or of complementary operation factors. Example: Rural, urban, industrial, marine, chemical, etc. (ISO, 2012)

- "Industrial atmosphere": The atmosphere contaminated by corrosive pollutants from local and regional industry (mainly sulphur dioxide) (CEN (European Committee for Standardization), 2017)

- "Marine atmosphere": The atmosphere over and dear the sea. NOTE: A marine atmosphere will extend a certain distance inland, depending on topography and prevailing wind direction. It is heavily polluted with sea-salt aerosols (mainly chlorides) (CEN (European Committee for Standardization), 2017).

- "Rural atmosphere": The atmosphere prevailing in rural areas and small towns, without significant contamination by corrosive agents such as sulphur dioxide and/or chlorides" (CEN (European Committee for Standardization), 2017)

- "Urban atmosphere": The contaminated atmosphere prevailing in densely populated areas without significant industry. It has moderate concentrations of pollutants such as sulphur dioxide and/or chlorides" (CEN (European Committee for Standardization), 2017)

- "Corrosivity of atmosphere": ability of the atmosphere to cause corrosion in a given corrosion system (ISO, 2012)

- "Category of corrosivity atmosphere": standardized rating of corrosivity of atmosphere in relation to the one-year corrosion effect (ISO, 2012)

- "Category of location": conventionally defined typical exposure conditions of a component or structure. Example: Exposure in the open air, under shelter, in a closed space, etc. (ISO, 2012)

- "Corrosion rate": corrosion effect on a metal per unit time. Note: The unit used to express the corrosion rate depends on the technical system and on the type of corrosion effect. Thus, corrosion rate is typically expressed as an increase in corrosion depth per unit time, or the mass of metal turned into corrosion products per area of surface and per unit time, etc. The corrosion effect may vary with time and may not be the same at all points of the corroding surface. Therefore, reports of corrosion rates are typically accompanied by information on the type, time dependency and location of the corrosion effect. (ISO, 2020)

- "Corrosivity": ability of an environment to cause corrosion of a metal in a given corrosion system (ISO, 2020).

- "Corrosion system": system consisting of one or more metals and those parts of the environment that influence corrosion (ISO, 2020)

\subsubsection{Electrochemical corrosion}

Corrosion is motivated by reaction mechanisms produced by the own tendency of metals to give up electrons, with the consequent tendency of them to return to their original state. Thus, one can speak of a chemical phenomenon consequent on the tendency of metals to return to their original state, that is, to their state before being extracted for metallurgical treatment.

Although there may be several classifications of corrosion depending on very different parameters, in this thesis it is advisable to carefully analyse the following types of oxidation:

- Electrochemical corrosion

- Direct oxidation

Electrochemical corrosion is produced by forming in metals bound with different electrochemical potentials or in the same metal with heterogeneous interfaces, galvanic cells, by the action of an electrolyte that could be an acid, water films (humidity), etc., by which produces a transfer of electrons from one metal to another, producing an electric current from the metal anode to the cathode, in such a way that the anode is oxidized (transfer of electrons) producing a corrosive process, while the cathode is reduces (gain of electrons) not causing any type of attack. 
It can therefore be affirmed, that two types of reactions take place in this type of electrochemical phenomenon:

a) Anodic reaction or oxidation reaction

It is the reaction by which the anode yields electrons to the cathode through the electrolyte, and can be summarized as follows:

$\mathrm{Me} \rightarrow \mathrm{Me}^{\mathrm{z}+}+\mathrm{ze}$

Examples of anodic reactions are:

$\mathrm{Zn} \rightarrow \mathrm{Zn}^{++}+2 \mathrm{e}$

$\mathrm{Al} \rightarrow \mathrm{Al}^{+3}+3 \mathrm{e}$

b) Cathodic reaction or reduction reaction

It is the reaction by which the cathode captures electrons through the electrolyte, coming from the anode. Some examples of these reactions are:

$\mathrm{H}^{+} \rightarrow 1 / 2 \mathrm{H}_{2}-\mathrm{e}$

$\mathrm{Cu}^{++} \rightarrow \mathrm{Cu}-2 \mathrm{e}$

Electrochemical corrosion is also known as aqueous corrosion or wet corrosion, and in it electrons travel through the metal from anodic to cathodic regions, completing the electrical circuit through the electrolyte (ionic conductivity solution). Thus, in this type of corrosion an electrolyte is necessarily required, which can be an acid solution or an aqueous solution, the latter determining in atmospheric corrosion processes, which will be analysed later. The operation of this type of corrosion is therefore similar to that of a galvanic cell, as expressed in the following figure (Uhlig, 1979):

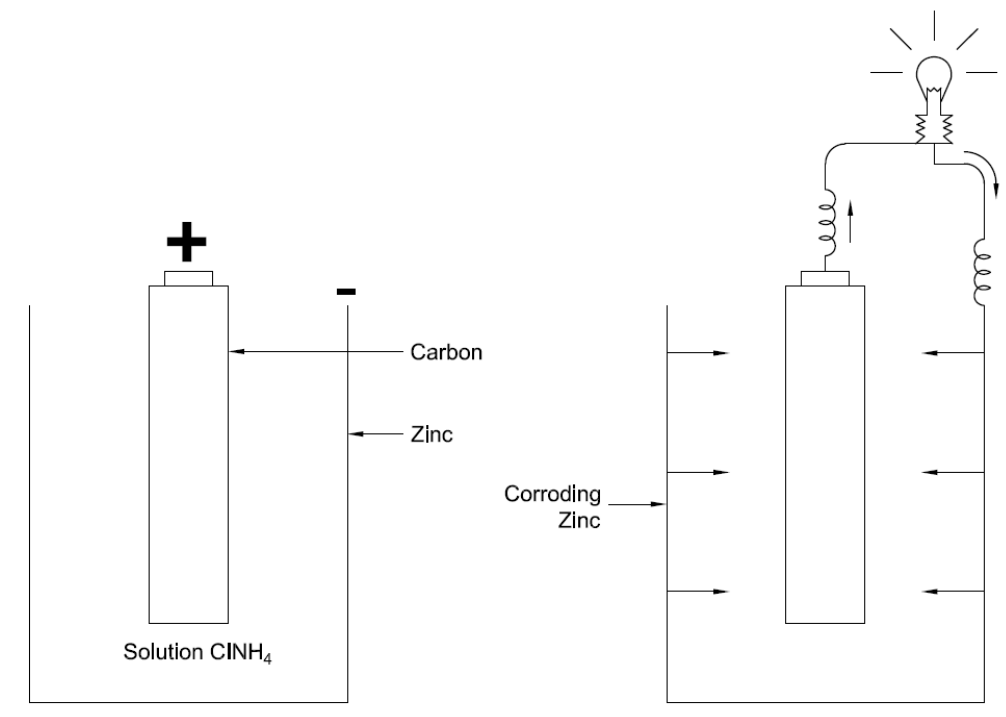

Figure 4: General scheme of a dry cell with $\mathrm{ClNH}_{4}$ as electrolyte

As can be seen in Figure 4, the electrochemical phenomenon of cell operation would consist of the transformation of chemical energy into electrical energy, in such a way that the electrical union through the lamp of the two metals in contact through an electrolyte, produce a current of electrons from the anode (zinc) to the cathode (carbon) that produce the illumination of the lamp. The battery is depleting as the zinc dissolves due to the oxidation it undergoes in this process. Well, this dissolution of zinc would constitute the corrosive phenomenon, when this process is applied to metal corrosion. Furthermore, it can be stated that the corrosion processes are almost always electrochemical.

Figure 5 and Figure 6 shown below, show schematically, the process of electrochemical corrosion in the two most common situations with which any type of industrial installation will be found: Electrolyte in acid solution and electrolyte in saline solution with dissolved oxygen. In addition, iron has been included in 
these schemes as the base metal that is usually common for instance in the case study (galvanized sheet trays, wire mesh trays and ladder trays, that is, the most widely used metal trays on the market).

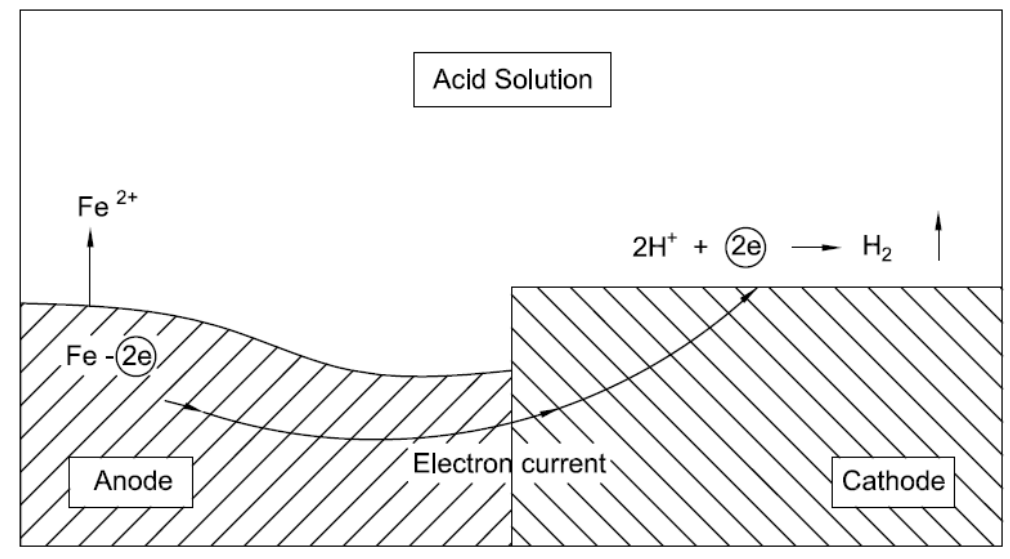

Figure 5: Diagram of the operation of an acid solution corrosion cell

In this scheme the iron (anode) is oxidized, giving up electrons and causing corrosion, while the cathode receives the electrons which combine with hydrogen, giving rise to hydrogen emissions, not causing any type of attack on it.

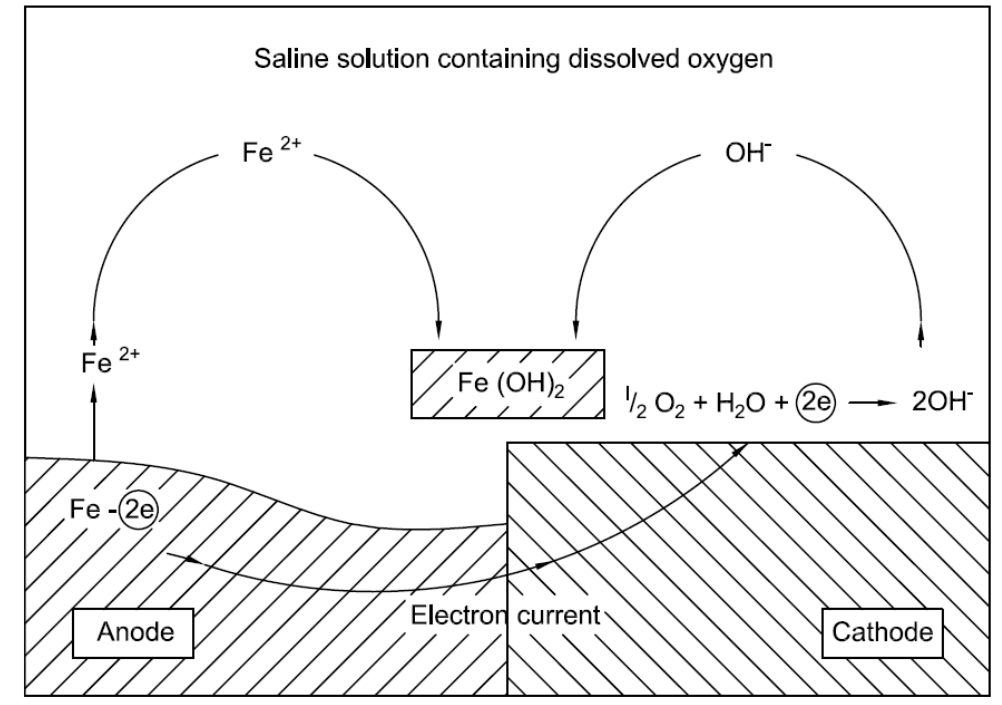

Figure 6: Diagram of the operation of an aerated neutral solution corrosion cell

In this case, it can be seen that the iron acts as an anode again, only that the electrons it transfers to the cathode are captured by the reaction of oxygen and water, producing $\mathrm{OH}^{-}$ions, which in turn react with $\mathrm{Fe}^{2+}$ ions to form iron hydroxide.

\subsubsection{Electrochemical potential}

All electric current is generated by a potential difference between two electrodes that make up the anode and the cathode, which, once produced their electrical connection, generate an electric current caused by the flow of electrons from the anode to the cathode. The current intensity will depend on the medium through which these electrons circulate and, obviously, on the existing potential difference. This phenomenon, as previously mentioned, is the one that produces in most of the cases the corrosion of metals and especially atmospheric corrosion phenomena.

Thus, for electrochemical corrosion to occur there must be an electrochemical potential that is capable of activating the flow of electrons necessary for corrosion to occur. Electrochemical potential differences are 
the origin of some regions acting anodically and others acting cathodically. In this sense, the electrochemical potential can be caused by:

- Metals of different nature and with significant electrochemical potential.

- In the same metal, due to heterogeneities that cause different phases within it, which in turn cause the necessary electrochemical potential, as will be seen later.

Table 1 shows the different electrochemical standard electrode potentials in aqueous solution at $25^{\circ} \mathrm{C}$ ("Hyperphisics," 2020). The other semi-element is formed by the various metals against solutions of their unit activity ions.

Table 1: Standard Electrode Potentials in Aqueous Solution at $25^{\circ} \mathrm{C}$

\begin{tabular}{|c|c|}
\hline Cathode (Reduction) - Half-Reaction & $\begin{array}{c}\text { Standard oxidation Potential } \\
\text { E (volts), } 25^{\circ} \mathrm{C}\end{array}$ \\
\hline $\mathrm{Li}^{+}(\mathrm{aq})+\mathrm{e}^{-} \rightarrow \mathrm{Li}(\mathrm{s})$ & $-3,04$ \\
\hline $\mathrm{K}^{+}(\mathrm{aq})+\mathrm{e}^{-} \rightarrow \mathrm{K}(\mathrm{s})$ & $-2,92$ \\
\hline $\mathrm{Ca}^{2+}(\mathrm{aq})+2 \mathrm{e}^{-} \rightarrow \mathrm{Ca}(\mathrm{s})$ & $-2,76$ \\
\hline $\mathrm{Na}^{+}(\mathrm{aq})+\mathrm{e}^{-} \rightarrow \mathrm{Na}(\mathrm{s})$ & $-2,71$ \\
\hline $\mathrm{Mg}^{2+}(\mathrm{aq})+2 \mathrm{e}^{-} \rightarrow \mathrm{Mg}(\mathrm{s})$ & $-2,38$ \\
\hline $\mathrm{Al}^{3+}(\mathrm{aq})+3 \mathrm{e}^{-} \rightarrow \mathrm{Al}(\mathrm{s})$ & $-1,66$ \\
\hline $2 \mathrm{H}_{2} \mathrm{O}(\mathrm{l})+2 \mathrm{e}^{-} \rightarrow \mathrm{H}_{2}(\mathrm{~g})+2 \mathrm{OH}^{-}(\mathrm{aq})$ & $-0,83$ \\
\hline $\mathrm{Zn}^{2+}(\mathrm{aq})+2 \mathrm{e}^{-} \rightarrow \mathrm{Zn}(\mathrm{s})$ & $-0,76$ \\
\hline $\mathrm{Cr}^{3+}(\mathrm{aq})+3 \mathrm{e}^{-} \rightarrow \mathrm{Cr}(\mathrm{s})$ & $-0,74$ \\
\hline $\mathrm{Fe}^{2+}(\mathrm{aq})+2 \mathrm{e}^{-} \rightarrow \mathrm{Fe}(\mathrm{s})$ & $-0,41$ \\
\hline $\mathrm{Cd}^{2+}(\mathrm{aq})+2 \mathrm{e}^{-} \rightarrow \mathrm{Cd}(\mathrm{s})$ & $-0,40$ \\
\hline $\mathrm{Ni}^{2+}(\mathrm{aq})+2 \mathrm{e}^{-} \rightarrow \mathrm{Ni}(\mathrm{s})$ & $-0,23$ \\
\hline $\mathrm{Sn}^{2+}(\mathrm{aq})+2 \mathrm{e}^{-} \rightarrow \mathrm{Sn}(\mathrm{s})$ & $-0,14$ \\
\hline $\mathrm{Pb}^{2+}(\mathrm{aq})+2 \mathrm{e}^{-} \rightarrow \mathrm{Pb}(\mathrm{s})$ & $-0,13$ \\
\hline $\mathrm{Fe}^{3+}(\mathrm{aq})+3 \mathrm{e}^{-} \rightarrow \mathrm{Fe}(\mathrm{s})$ & $-0,04$ \\
\hline $2 \mathrm{H}^{+}(\mathrm{aq})+2 \mathrm{e}^{-} \rightarrow \mathrm{H}_{2}(\mathrm{~g})$ & 0,00 \\
\hline $\mathrm{Sn}^{4+}(\mathrm{aq})+2 \mathrm{e}^{-} \rightarrow \mathrm{Sn}^{2+}(\mathrm{aq})$ & 0,15 \\
\hline $\mathrm{Cu}^{2+}(\mathrm{aq})+\mathrm{e}^{-} \rightarrow \mathrm{Cu}^{+}(\mathrm{aq})$ & 0,16 \\
\hline $\begin{array}{l}\mathrm{ClO}_{4}^{-}(\mathrm{aq})+\mathrm{H}_{2} \mathrm{O}(\mathrm{l})+2 \mathrm{e}^{-} \rightarrow \mathrm{ClO}_{3}^{-}(\mathrm{aq})+ \\
2 \mathrm{OH}^{-}(\mathrm{aq})\end{array}$ & 0,17 \\
\hline $\mathrm{AgCl}(\mathrm{s})+\mathrm{e}^{-} \rightarrow \mathrm{Ag}(\mathrm{s})+\mathrm{Cl}^{-}(\mathrm{aq})$ & 0,22 \\
\hline $\mathrm{Cu}^{2+}(\mathrm{aq})+2 \mathrm{e}^{-} \rightarrow \mathrm{Cu}(\mathrm{s})$ & 0,34 \\
\hline $\begin{array}{l}\mathrm{ClO}_{3}^{-}(\mathrm{aq})+\mathrm{H}_{2} \mathrm{O}(\mathrm{l})+2 \mathrm{e}^{-} \rightarrow \mathrm{ClO}_{2}^{-}(\mathrm{aq})+ \\
2 \mathrm{OH}^{-}(\mathrm{aq})\end{array}$ & 0,35 \\
\hline $\begin{array}{l}\mathrm{IO}^{-}(\mathrm{aq})+\mathrm{H}_{2} \mathrm{O}(\mathrm{l})+2 \mathrm{e}^{-} \rightarrow \mathrm{I}^{-}(\mathrm{aq})+2 \mathrm{OH}^{-} \\
(\mathrm{aq})\end{array}$ & 0,49 \\
\hline $\mathrm{Cu}^{+}(\mathrm{aq})+\mathrm{e}^{-} \rightarrow \mathrm{Cu}(\mathrm{s})$ & 0,52 \\
\hline $\mathrm{I}_{2}(\mathrm{~s})+2 \mathrm{e}^{-} \rightarrow 2 \mathrm{I}^{-}(\mathrm{aq})$ & 0,54 \\
\hline $\begin{array}{l}\mathrm{ClO}_{2}^{-}(\mathrm{aq})+\mathrm{H}_{2} \mathrm{O}(\mathrm{l})+2 \mathrm{e}^{-} \rightarrow \mathrm{ClO}^{-}(\mathrm{aq})+ \\
2 \mathrm{OH}^{-}(\mathrm{aq})\end{array}$ & 0,59 \\
\hline $\mathrm{Fe}^{3+}(\mathrm{aq})+\mathrm{e}^{-} \rightarrow \mathrm{Fe}^{2+}(\mathrm{aq})$ & 0,77 \\
\hline $\mathrm{Hg}_{2}{ }^{2+}(\mathrm{aq})+2 \mathrm{e}^{-} \rightarrow 2 \mathrm{Hg}(\mathrm{l})$ & 0,80 \\
\hline $\mathrm{Ag}^{+}(\mathrm{aq})+\mathrm{e}^{-} \rightarrow \mathrm{Ag}(\mathrm{s})$ & 0,80 \\
\hline $\mathrm{Hg}^{2+}(\mathrm{aq})+2 \mathrm{e} \rightarrow \mathrm{Hg}(\mathrm{l})$ & 0,85 \\
\hline $\begin{array}{l}\mathrm{ClO}^{-}(\mathrm{aq})+\mathrm{H}_{2} \mathrm{O}(\mathrm{l})+2 \mathrm{e}^{-} \rightarrow \mathrm{Cl}^{-}(\mathrm{aq})+2 \mathrm{OH}^{-} \\
(\mathrm{aq})\end{array}$ & 0,90 \\
\hline $2 \mathrm{Hg}^{2+}(\mathrm{aq})+2 \mathrm{e}^{-} \rightarrow \mathrm{Hg}_{2}^{2+}(\mathrm{aq})$ & 0,90 \\
\hline
\end{tabular}




$\begin{array}{lr}\mathrm{NO}_{3}-(\mathrm{aq})+4 \mathrm{H}^{+}(\mathrm{aq})+3 \mathrm{e}^{-} \rightarrow \mathrm{NO}(\mathrm{g})+ & 0,96 \\ 2 \mathrm{H}_{2} \mathrm{O}(\mathrm{l}) & 1,07 \\ \mathrm{Br}_{2}(\mathrm{l})+2 \mathrm{e}^{-} \rightarrow 2 \mathrm{Br}^{-}(\mathrm{aq}) & 1,23 \\ \mathrm{O}_{2}(\mathrm{~g})+4 \mathrm{H}^{+}(\mathrm{aq})+4 \mathrm{e}^{-} \rightarrow 2 \mathrm{H}_{2} \mathrm{O}(\mathrm{l}) & 1,33 \\ \mathrm{Cr}_{2} \mathrm{O}_{7}^{2-}(\mathrm{aq})+14 \mathrm{H}^{+}(\mathrm{aq})+6 \mathrm{e}^{-} \rightarrow 2 \mathrm{Cr}^{3+}(\mathrm{aq}) & 1,36 \\ +7 \mathrm{H}_{2} \mathrm{O}(\mathrm{l}) & 1,44 \\ \mathrm{Cl}_{2}(\mathrm{~g})+2 \mathrm{e}^{-} \rightarrow 2 \mathrm{Cl}^{-}(\mathrm{aq}) & 1,49 \\ \mathrm{Ce}^{4+}(\mathrm{aq})+\mathrm{e}^{-} \rightarrow \mathrm{Ce}^{3+}(\mathrm{aq}) & 1,78 \\ \mathrm{MnO}_{4}^{-}(\mathrm{aq})+8 \mathrm{H}^{+}(\mathrm{aq})+5 \mathrm{e}^{-} \rightarrow \mathrm{Mn}^{2+}(\mathrm{aq})+ & 1,82 \\ 4 \mathrm{H}_{2} \mathrm{O}(\mathrm{l}) & 2,01 \\ \mathrm{H}_{2} \mathrm{O}_{2}(\mathrm{aq})+2 \mathrm{H}^{+}(\mathrm{aq})+2 \mathrm{e}^{-} \rightarrow 2 \mathrm{H}_{2} \mathrm{O}(\mathrm{l}) & 2,07 \\ \mathrm{Co}^{3+}(\mathrm{aq})+\mathrm{e}^{-} \rightarrow \mathrm{Co}^{2+}(\mathrm{aq}) & 2,87 \\ \mathrm{~S}_{2} \mathrm{O}_{8}{ }^{2-}(\mathrm{aq})+2 \mathrm{e}^{-} \rightarrow 2 \mathrm{SO}_{4}^{2-}(\mathrm{aq}) & \\ \mathrm{O}_{3}(\mathrm{~g})+2 \mathrm{H}^{+}(\mathrm{aq})+2 \mathrm{e}^{-} \rightarrow \mathrm{O}_{2}(\mathrm{~g})+\mathrm{H}_{2} \mathrm{O}(\mathrm{l}) & \\ \mathrm{F}_{2}(\mathrm{~g})+2 \mathrm{e}^{-} \rightarrow 2 \mathrm{~F}^{-}(\mathrm{aq}) & \end{array}$

\subsubsection{Atmospheric corrosion}

One of the most important problems that the designer of any installation in industrial plants must face is atmospheric corrosion. The action of the atmosphere on metals is one of the biggest problems posed by corrosion. More than $50 \%$ of corrosion losses are due to atmospheric corrosion.

For the scope of this thesis, atmospheric corrosion is especially significant in those installations which are carried out outside the buildings, that is, in direct contact with the environment. Likewise, within this same clause, a section is dedicated to the phenomenon of atmospheric corrosion in marine environments, given the aggressiveness of the medium on the metals located in this type of environment and its disastrous consequences, in case of not carrying out an adequate design of the materials to be used and their corrosive protection.

According to A. Stern (Stern, 1986) there are 5 types of atmospheric mechanisms through which deterioration of materials occurs:

1- Abrasion

2- Deposition and elimination

3- Direct chemical attack

4- Indirect chemical attack

5- Electrochemical corrosion

Likewise, Stern classifies the main factors that influence the deterioration of the atmosphere:

1- Humidity. Without moisture in the atmosphere, there would be very little, if any, atmospheric corrosion even in the most polluted environments.

2- Temperature. The most obvious of temperature influences is on the increase in chemical reactions resulting in deterioration.

3- Sunlight. In addition to producing deterioration agents such as ozone, sunlight can cause direct deterioration of certain materials.

4- Air movement. For example, the leather of books deteriorates when the wind hits them with $\mathrm{SO}_{2}$ molecules.

5- Other factors. For example: The position in space.

Of all of them, atmospheric corrosion especially electrochemical corrosion, affecting to a greater or lesser extent each and every one of the 5 factors listed that influence atmospheric deterioration.

Atmospheric corrosion is a process that we could call purely electrolytic in nature (see 2.1.2) since it is only produced through the presence of an electrolyte, in this case water. For outdoor environments, water is deposited on the metal basically through two possible actions:

- The different meteorological actions that contribute water to the metal: Rain, fog, humidity, dew, etc.

- Temperature changes that cause a temperature difference between the metal and the environment such that saturation of the atmosphere occurs, and water condensation occurs on the metal surface. The more 
pronounced that difference is, the more condensation will occur, or what is the same, the drier the environment, the greater the drop in temperature that will cause moisture condensation.

In this sense, it can be affirmed that without the presence of water and at temperatures revolving around room temperature, there would be no corrosion. For this reason, there are indicators of atmospheric corrosion based on the times in which there is significant humidity in the environment, these indicators being in some cases quite acceptable to establish an order of magnitude of the effect of atmospheric corrosion in the area.

\subsubsection{Influencing atmospheric pollutants in corrosion processes}

Apart from humidity as the main factor that favours the onset of atmospheric corrosion in metals, it is also worth highlighting the effect of atmospheric pollutants as the main factors to multiply the corrosive effect. These contaminants can cause corrosion to increase in speed more than twice what it would in corrosionfree environments. In this sense, the main atmospheric pollutants can be of a natural type, considering as the most important chlorides $(\mathrm{NaCl})$ and those caused by man, among which it is worth highlighting the $\mathrm{SO}_{2}$ coming mainly from the combustion processes of fuels with high sulphur content: engines, vehicles, industry, thermal power plants, garbage dumps, urban pollution, etc. For example, thermoelectric plants, refineries and paper mills contribute $85 \%$ of the $\mathrm{SO}_{2}$ in the atmosphere (Ocampo, 1986).

Sulphur dioxide

This pollutant comes mainly, as previously mentioned, from human pollution activities, although it can also come from natural sources such as volcanic eruptions. $\mathrm{SO}_{2}$ emitted into the atmosphere can be either oxidized in it and converted to sulfuric acid through homogeneous or heterogeneous reactions or eliminated in the form of deposition either on water, plants and buildings, or eliminated in the form of dry deposition on water, plants and buildings or be installed by living animals or humans. The corrosion process occurs due to the rapid absorption of $\mathrm{SO}_{2}$ by iron in such a way that when the water layer is produced on the metal, the contaminant acts as a powerful catalyst for the reaction, notably increasing the diffusion rates of the same. The chemical reactions would be as follows (Morcillo \& Feliu, 1993):

- $\quad$ Formation of ferrous sulphate: $\mathrm{Fe}+\mathrm{SO}_{2}+\mathrm{O}_{2} \rightarrow \mathrm{FeSO}_{4}$

- Rust and sulfuric acid formation: $4 \mathrm{FeSO}_{4}+\mathrm{O}_{2}+6 \mathrm{H}_{2} \mathrm{O} \rightarrow 4 \mathrm{FeOOH}+4 \mathrm{H}_{2} \mathrm{SO}_{4}$

- Formation of iron sulphate: $4 \mathrm{H}_{2} \mathrm{SO}_{4}+4 \mathrm{Fe}+2 \mathrm{O}_{2} \rightarrow 4 \mathrm{FeSO}_{4}+4 \mathrm{H}_{2} \mathrm{O}$

Nitrogen oxides

Nitrogen oxides (NOx) are emitted by natural sources, such as forest fires, volcanic activity, and microbial processes in soils, being distributed over the entire surface of the earth. These oxides are also produced in the combustion processes. Of all the existing types of Nitrogen Oxides, only two of them, Nitric Oxide (NO) and Nitrogen Dioxide $\left(\mathrm{NO}_{2}\right)$ affect the atmospheric corrosion process.

$\underline{\text { Ozone }}$

Ozone is an important constituent in the upper atmosphere. Like the other natural constituents of the atmosphere, ozone has a highly variable concentration depending on geographic location and altitude.

\section{Atmospheric particles}

Particulate matter in the atmosphere consists of solid and liquid particles emitted from numerous sources, both natural and artificial. This particulate matter is a complex and variable mixture of particles of different sizes and with very diverse chemical components. The normal thing is to classify said particles by their size, existing in the reference bibliography, different criteria to carry out this classification. For legislative purposes, atmospheric particles can be divided into sedimentary particles (diameter greater than $10 \mu \mathrm{m}$ ) and suspended particles (diameter less than $10 \mu \mathrm{m}$ ).

The deposition of pollutants from the atmosphere can take place dry, by adsorption of the pollutant by the metal in gaseous form, or through rain (acid rain).

\section{$\underline{\text { Chlorides }}$}

Regarding chlorine particles, they usually occur in environments near the coasts of the beaches. There is a certain correlation between the effect of these particles and the direct distance to the coasts on which they are produced. Therefore, given this variation, it is convenient to know the effect of particles in areas near the coast depending on their distance, since after a few kilometres, these effects can be considered 
negligible. Another relatively important source of chlorine ions usually comes from volcanic eruptions, which can emit around 3 million tons of hydrochloric acid annually.

\subsubsection{Mechanical tension and corrosion}

When a metal is subjected to a certain stress, be it intrinsic (internal or residual stresses) or extrinsic (mechanical demands for the intended use), in certain corrosive media, the corrosion of the same can be accentuated to the point of producing break. This phenomenon is especially important for the research work at hand, given that all metal cable trays are going to be subject to internal stresses due to their shape and drawing, and to extrinsic stresses as they are elements intended to support loads (electrical conductors).

Two phenomena exist for this type of corrosion:

- Corrosion under stress

- Fatigue due to corrosion

Corrosion fatigue occurs when the mechanical stresses to which the product is subjected are repetitive stresses, alternating tensile and compressive stresses.

In general, stress corrosion occurs, therefore, in metal products obtained by significant deformations of the metal to obtain its final shape (accumulation of significant residual stresses) or metals with a significant mechanical load.

Initially, this type of metal remains passive until a certain threshold of mechanical demand is exceeded, from which the material begins to crack and easily reaches breakage. In the case of fatigue with corrosion, the number of fatigue cycles, that the material that is surrounded by a corrosive medium resist, is much less than that obtained for the material in a safe environment.

Thus, this type of corrosion is manifested by mechanical failure by cracking in circumstances such that, if there were no corrosion, the failure would not be expected to occur. What they have in common is cracking: cracks start spontaneously and spread until fracture occurs under the influence of some type of corrosion process.

\subsection{Galvanization processes}

Regarding the scope of this doctoral thesis, two types of processes for zinc-based surface coatings will be considered, which are described below:

\subsubsection{Discontinuous galvanizing}

Discontinuous galvanization, "post-galvanized" or "hot-dip galvanized" (hereinafter HDG), as it is commonly known, is a procedure of applying a zinc coating on steel or cast-iron parts by immersing them in a bath cast zinc.

The actual galvanizing operation is carried out by immersing the parts in a molten zinc bath, at a temperature generally comprised between $440^{\circ} \mathrm{C}$ and $460^{\circ} \mathrm{C}$. The minimum purity of zinc to use is specified by most European and international zinc standards and is around 98.5\%. During the immersion of the pieces in the molten zinc, zinc diffusion occurs on the steel surface, which leads to the formation of different layers of zinc-iron alloys of different composition. When the pieces are removed from the galvanizing bath, these alloys are covered with an external zinc layer similar in composition to that of the bath zinc.

Once out of the galvanizing bath, the parts can be cooled in water or let them cool in air. Next, they are reviewed to eliminate burrs, sharp drops, superficial adhesion of ashes or salt remains and finally, they are inspected. Galvanized coatings on various articles must meet a series of requirements regarding surface appearance, adhesion and thickness that are specified in national and international standards. The currently applicable national and international standard is EN ISO 1461 (CEN, 2009).

Other of the main characteristics of hot-dip galvanizing, which is why it is the quintessential surface treatment for resistance to corrosion, is the thickness or microns that the pieces can acquire. While continuous galvanizing has microns ranging from 5 to 40 microns, hot dip galvanizing can obtain microns of up to 200 microns, a feature that ensures very high corrosion resistance even in the most aggressive environments, since, despite the high corrosion rates of these environments, they are somehow "compensated" with these high microns. 


\subsubsection{Continuous galvanizing}

Continuous galvanizing, also known as pre-galvanizing or Sendzimir, is a particular case of hot-dip galvanizing, whereby steel strips are continuously immersed in a zinc bath and subsequently subjected to additional treatment. Galvanized steel strip is a product that is, generally, mechanically treated later (diecut, punching, bending ...) to obtain final parts. The disadvantage of this type of process is that they leave the steel bare in those parts where a material cut occurs. In this sense, unlike continuous galvanizing processes, which would include zinc / aluminium / magnesium alloys (designated according to regulations by ZM alloys), in the hot (or discontinuous) galvanizing process all parts of the piece are covered, including cuts, welds, deep cuts, hollow parts, etc.

Zinc-Aluminium-Magnesium alloys are also a particular case of continuous galvanizing. In recent years, different types of alloys have been developed, which aim is to increase resistance to corrosion while reducing the cost of traditional coatings, such as hot-dip galvanizing. According to the manufacturers of this type of finish, this reduction in cost would be based on the reduction in the amount of coating material per unit area (generally measured in microns or $\mathrm{g} / \mathrm{m}^{2}$ ) at the cost of a supposed lower corrosion rate.

\subsection{Long-term corrosion calculation on zinc-based coatings}

Regarding the scope of this thesis, which is based in $\mathrm{ZM}$ and $\mathrm{Z}$ coatings, the background for long-term corrosion calculations is mostly focused in $\mathrm{Z}$ coatings for which, since it is used from the beginning of the 20th century, a large amount of information is available, both in the field of accelerated corrosion tests and in the field of field tests. The most difficult point regarding this topic, is the way the many different factors that influences atmospheric corrosion (moisture, wetness time, temperature, pollutants, etc.). Several mathematical models have been developed by many authors and there is a big amount of information in that respect.

The works done by Chenoll et al. regarding this subject are especially relevant (Chenoll-Mora, CloquellBallester, \& Santamarina-Siurana, 2018; Chenoll Mora, 2005; Ernesto Chenoll-Mora \& Vicente Agustín Cloquell-Ballester, 2019), since they synthesize the relevant background in what long-term corrosion resistance calculation respects and in addition, offers mathematical models to estimate this resistance over time.

\subsubsection{Zinc-based coatings}

The previous referred authors (Chenoll-Mora et al., 2018; Chenoll Mora, 2005) based their work on two steps:

- Calculation of corrosion after one year (first year of exposure)

- Calculation of the corrosion for any period of time (beyond one year of exposure)

As shown in previous studies like (Feliu Batlle, Morcillo, \& Feliu, 1993a; González Fernández, 1984; ISO, 2012; Pourbaix, 1982a), the corrosion in most of the cases, is estimated by means of bi-logarithmic expressions of the type:

Equation 1: General long-term corrosion expression

$$
\mathrm{C}(\mathrm{t})=A t^{\mathrm{n}}
$$

(Equation 1)

where,

- $C(t)$ is the accumulated corrosion at year $t$.

- $A$ is the corrosion at first year of exposure.

- $n$ is a constant, which depends on each metal and the particular atmospheric condition; generally, $n<1$.

$-t$ is the time in years.

In order to determine the corrosion during the first year of exposure $(A), 10$ studies were selected in order to determine the best fitting model to actual corrosion values. Table 2 shows the different variables and parameters considered on those techniques. 
Table 2: Variables and parameters used in the methods to estimate annual corrosion (A)

\begin{tabular}{|c|c|c|}
\hline $\begin{array}{l}\text { Variable / } \\
\text { Parameter }\end{array}$ & Description / Value & Units \\
\hline $\mathrm{A}_{\mathrm{x}}$ & Corrosion at first year of exposure calculated with method $\mathrm{x}$ & Microns $(\mu \mathrm{m})$ \\
\hline RH & Average annual relative humidity & $\%$ \\
\hline $\mathrm{T}$ & Average annual temperature & ${ }^{\circ} \mathrm{C}$ \\
\hline $\mathrm{L}$ & Number of rainy days per year & Days \\
\hline $\mathrm{W}$ & $\begin{array}{l}\text { Wetness time estimated, as the number of hours in one year during which } R H \geq \\
80 \% \text { and } T>0^{\circ} \mathrm{C} \text { simultaneously (ISO, 2012) }\end{array}$ & Hours \\
\hline M & $\begin{array}{l}\text { Corrosion module for } 1000 \mathrm{~h} \text { of wetness of the metal surface in a pure atmosphere } \\
\text { (free of contaminants); for the case of zinc it corresponds to } 0.4 \mu \mathrm{m}\end{array}$ & $\mu \mathrm{m}$ \\
\hline$t_{w}$ & Wetness time & Hours/1000 \\
\hline $\mathrm{f}_{\mathrm{t}}$ & Coefficient of corrosion inhibition with the annual wetness time ( $t$ ) & Constant \\
\hline$\alpha$ & Influence of $\mathrm{SO}_{2}$ contamination & Constant \\
\hline B & Influence of $\mathrm{Cl}^{-}$contamination & Constant \\
\hline$f_{c}$ & Stimulating coefficient of corrosion due to contaminants in the air & Constant \\
\hline $\mathrm{Cl}^{-}:$ & Average annual concentration of chlorides & $\mathrm{mg} \cdot\left(\mathrm{m}^{-2} \cdot \mathrm{d}^{-1}\right)$ \\
\hline $\mathrm{S}$ & Average annual concentration of sulphur dioxide $\left(\mathrm{SO}_{2}\right)$ & $\mathrm{mg} \cdot\left(\mathrm{m}^{-2} \cdot \mathrm{d}^{-1}\right)$ \\
\hline $\mathrm{S}^{*}$ & Average annual concentration of $\mathrm{SO}_{2}+\mathrm{Cl}^{-}$ & $\mathrm{mg} \cdot\left(\mathrm{m}^{-2} \cdot \mathrm{d}^{-1}\right)$ \\
\hline $\mathrm{P}_{\mathrm{d}}$ & Annual average $\mathrm{SO}_{2}$ deposition & $\mathrm{mg} \cdot\left(\mathrm{m}^{-2} \cdot \mathrm{d}^{-1}\right)$ \\
\hline$f_{Z n}$ & 0.038. $(\mathrm{T}-10)$ when $\mathrm{T}<=10^{\circ} \mathrm{C}$; otherwise, $-0.071 \cdot(\mathrm{T}-10)$ & ${ }^{\circ} \mathrm{C}$ \\
\hline $\mathrm{S}_{\mathrm{d}}$ & Annual average $\mathrm{Cl}^{-}$deposition & $\mathrm{mg} \cdot\left(\mathrm{m}^{-2} \cdot \mathrm{d}^{-1}\right)$ \\
\hline $\mathrm{d}$ & Day & - \\
\hline
\end{tabular}

The referred methods are summarized below:

Method 1: Applicable in atmospheres exempt from contamination (Chico, De La Fuente, Vega, \& Morcillo, 2010; Feliu \& Morcillo, 1980; Morcillo \& Feliu, 1987):

Equation 2: Long-term corrosion calculation in $\mathrm{Z}$ coatings (method 1)

$$
A_{l}=-0,00603 \cdot R H+0,0038 \cdot T+0,0093 \cdot L+0,597
$$

Method 2: Applicable in atmospheres exempt from contamination. This method is based on the same study from which Method 1 comes from.

Equation 3: Long-term corrosion calculation in $\mathrm{Z}$ coatings (method 2)

$$
A_{2}=-0,000198 \cdot W+0,015 \cdot T+0,015 \cdot L+0,215
$$

(Equation 3)

Method 3: Applicable in atmospheres exempt from contamination (Costa, Mercer, Institute of Materials of London, European Federation of corrosion, \& Sociedad Española de Química Industrial, 1993).

Equation 4: Long-term corrosion calculation in $\mathrm{Z}$ coatings (method 3)

$$
A_{3}=0,12 \cdot L-0,35
$$

(Equation 4)

Method 4: Applicable in any type of atmosphere (Morcillo \& Feliu, 1993)

Equation 5: Long-term corrosion calculation in $\mathrm{Z}$ coatings (method 4)

$$
A_{4}=M \cdot t_{w} \cdot f_{t} \cdot f_{c}
$$

Equation 5)

Where $\mathrm{f}_{\mathrm{c}}$ is calculated through the following expression:

Equation 6: Calculation of fc coefficient in Method 4 calculation method

$$
f c=1+\alpha+\beta
$$

Coefficient $\mathrm{f}_{\mathrm{t}}$ and parameters $\alpha$ and $\beta$, can be obtained by the following graphs in Figure 7 , Figure 8 , Figure 9: 


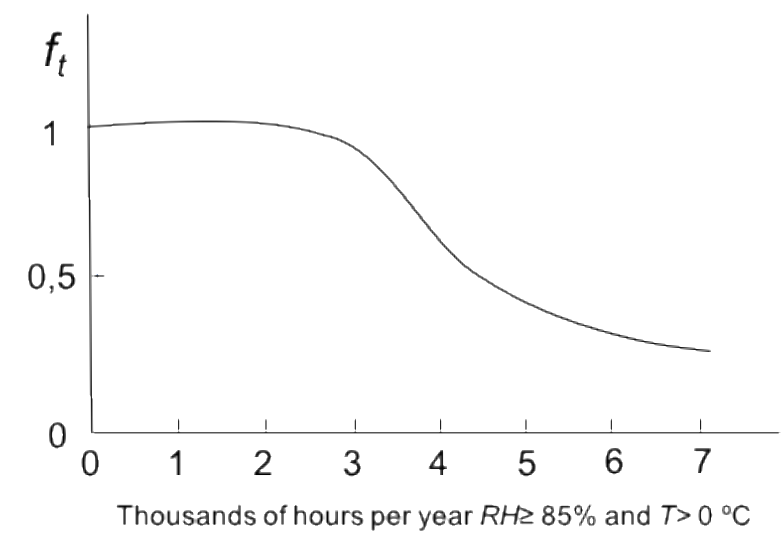

Figure 7: Variation of ft, versus wetness time. Source: own illustration based on reference (Morcillo \& Feliu, 1993)

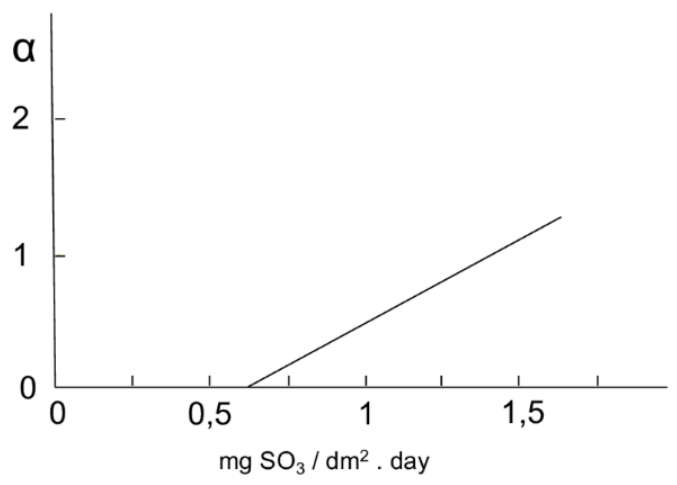

Figure 8: Variation of $\alpha$ versus mean values of $\mathrm{SO}_{2}$. Source: own illustration based on reference (Morcillo \& Feliu, 1993)

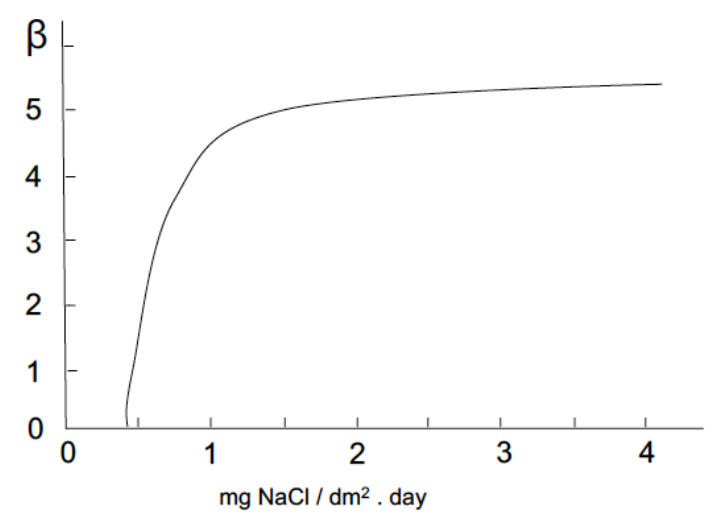

Figure 9: Variation of $\beta$ versus mean values of chlorides. Source: own illustration based on reference (Morcillo \& Feliu, 1993)

Method 5: Applicable in contaminated atmospheres (Morcillo, 1998; Morcillo \& Feliu, 1993)

Equation 7: Long-term corrosion calculation in $\mathrm{Z}$ coatings (method 5)

$$
A_{5}=0,713+0,0511 \cdot \mathrm{Cl}^{-}
$$

(Equation 7) 
Method 6: Applicable in any type of atmosphere (Almeida, Rosales, Uruchurtu, Marroco, \& Morcillo, 1999)

Equation 8: Long-term corrosion calculation in $\mathrm{Z}$ coatings (method 6)

$$
A_{6}=2,52 \cdot W+0,02 \cdot C l^{-}-0,05
$$

Method 7: Applicable in contaminated atmospheres. This method is part of the same study as that referenced in Method 10

Equation 9: Long-term corrosion calculation in $\mathrm{Z}$ coatings (method 7)

$$
A_{7}=0,785+0,0226 \cdot S+0,0501 \cdot C l^{-}
$$

(Equation 9)

Method 8: Applicable in any type of atmosphere (ISO, 2012)

Equation 10: Long-term corrosion calculation in $\mathrm{Z}$ coatings (method 8)

$$
A_{8}=0,0219 \cdot P_{d}{ }^{0,44} \cdot \mathrm{e}^{0,046 \cdot R H+f z n}+0,0175 \cdot S d^{0,57} \cdot \mathrm{e}^{0,008 \cdot R H+0,085 \cdot T}
$$

Method 9: Applicable in any type of atmosphere (Haagenrud, Henriksen, \& Gram, 1985)

Equation 11: Long-term corrosion calculation in $\mathrm{Z}$ coatings (method 9)

$$
A_{9}=12,26 \cdot W+0,03 \cdot S-3,05
$$

Method 10: Applicable in contaminated atmospheres (Benarie \& Lipfert, 1986; Feliu Batlle et al., 1993a; Feliu Batlle, Morcillo, \& Feliu, 1993b; Morcillo, 1998)

Equation 12: Long-term corrosion calculation in $\mathrm{Z}$ coatings (method 10)

$$
A_{10}=0,671+0,0741 \cdot S^{*}
$$

In order to complete Equation 1, $n$ value has to be determined. Several examples have been used to determine it, from which the following were selected:

It is commonly accepted ((Chico et al., 2010; Hernández, Miranda, \& Domínguez, 2002; ISO, 2012) that for the case of zinc, $n$-parameter is usually in the range of 0,8 to 1 , although this range depends on the type of environment of the installation.

For his part, M. Pourbaix (Pourbaix, 1982b) facilitates reference values, which are showed in Table 3:

Table 3: Possible values of n-parameter for different types of atmospheres

Rural atmosphere Urban-Industrial atmosphere Marine atmosphere

\begin{tabular}{lll}
\hline 0,65 & 0,9 & 0,9 \\
\hline
\end{tabular}

M. Morcillo (Morcillo, 1998) makes the analysis for exposures over 10 years (Table 4), based on actual field trials within the ISO CORRAG program (Dean \& Reiser, 2002; Knotkova, Boschek, \& Kreislova, 1995; Knotkova, Dean, \& Kreislova, 2010; Panchenko, Marshakov, Igonin, Kovtanyuk, \& Nikolaeva, 2014).

Table 4: $\mathrm{n}$ ranges obtained in long-term exposures (10-20 years)

\begin{tabular}{ccc}
$\begin{array}{c}\text { Rural-Urban atmosphere } \\
\text { away from the sea }\end{array}$ & $\begin{array}{c}\text { Industrial atmospheres } \\
\text { away from the sea }\end{array}$ & $\begin{array}{c}\text { Marine } \\
\text { atmosphere }\end{array}$ \\
\hline $0,8-1$ & $0,9-1$ & $0,7-0,9$ \\
\hline
\end{tabular}

The standard EN ISO 9224 (CEN, 2012), gives two values for $n$ : $B 1$ and B2 (Table 5). For general applications, $n$ will take the value of $B 1$. In those cases, where it is important to estimate a more conservative corrosion attack limit after long exposures, the value of $B$ should be increased to consider the uncertainties of the values of $B 1$. Value $B 2$ includes these uncertainties. Therefore, the use of $B 1$ or $B 2$ as the parameter $n$, will clearly depend on the degree of accuracy that is intended for the calculation. 
Table 5: n-parameter values for predicting and estimating zinc corrosion attack according to EN ISO 9224

\begin{tabular}{cc} 
B1 & B2 \\
\hline 0,813 & 0,873 \\
\hline
\end{tabular}

From this analysis, the designer must choose the most appropriate value of $n$, considering these general recommendations:

- As a general value, the one established by EN ISO 9224 (CEN, 2012), can be taken.

- For $t>20$ years, values between 0,9 and 1 should be chosen, because the zinc corrosion ratio becomes linear from this exposition time (ISO, 2012).

- For environments with very high concentrations of sulphur dioxide (P3), values between 0,9 and 1 should be used (ISO, 2012).

- For exposures in rural environments with very low pollution rates and for exposures around 10 years, lower values should be used for $n$, according to the previous tables, but not below 0,65.

Finally, it is advisable to review the information provided in the aforementioned ISO CORRAG program, which is used in many research studies in the field of corrosion (Dean \& Reiser, 2002; Knotkova et al., 1995, 2010; Panchenko et al., 2014).

\subsubsection{ZM alloys}

A research work (Ernesto Chenoll-Mora \& Vicente Agustín Cloquell-Ballester, 2019) was carried out with the aim of beginning to investigate the long-term corrosion behaviour of ZM alloys, based on the results of field tests for which only results of up to 2 years were available. The hypothesis of an equally logarithmic behaviour (Equation 1) was taken (Hypothesis 2 in this thesis). This hypothesis has not been corroborated at the date of today due to the little information available on long-term tests, and the research on it, is part of this thesis, as described in 1.2 Research hypothesis.

As it is shown in Table 6 and Figure 10, the research work concluded with an approximation of what the curves of long-term corrosion could look like, but only with the 2 years information had. It was clearly expressed, that the research work should be completed in the future when having more tests results and longer term.

Table 6: Long-term corrosion equations for the different corrosivity categories in ZM and ZA alloys

\begin{tabular}{cccccc} 
Alloy & Corrosivity category & $\begin{array}{c}\text { First year corrosion } \\
(A)\end{array}$ & $\begin{array}{c}\text { Cumulated } \\
\text { corrosion Y2 }\end{array}$ & $n$ & Long-term corrosion function \\
\hline ZM & C2 & 0,2 & 0,43 & 1,104 & $\mathrm{C}_{2}(\mathrm{t})=0,2 \cdot \mathrm{t}^{1,104}$ \\
$\mathrm{ZM}$ & $\mathrm{C} 3$ & 0,68 & 1,24 & 0,866 & $\mathrm{C}_{3}(\mathrm{t})=0,68 \cdot \mathrm{t}^{0,866}$ \\
$\mathrm{ZM}$ & $\mathrm{C} 4$ & 2,33 & 3,92 & 0,75 & $\mathrm{C}_{4}(\mathrm{t})=2,33 \cdot \mathrm{t}^{0,75}$ \\
$\mathrm{ZM}$ & $\mathrm{C} 5$ & 4,8 & 9 & 0,906 & $\mathrm{C}_{5}(\mathrm{t})=4,8 \cdot \mathrm{t}^{0,906}$ \\
$\mathrm{ZM}$ & $\mathrm{CX}$ & 6,23 & 12,08 & 0,955 & $\mathrm{C}_{\mathrm{x}}(\mathrm{t})=6,23 \cdot \mathrm{t}^{0,955}$ \\
$\mathrm{ZA}$ & $\mathrm{C} 3$ & 0,6 & 1,1 & 0,87 & $\mathrm{C}_{3 \mathrm{ZA}}(\mathrm{t})=0,6 \cdot \mathrm{t}^{0,87}$ \\
\hline
\end{tabular}




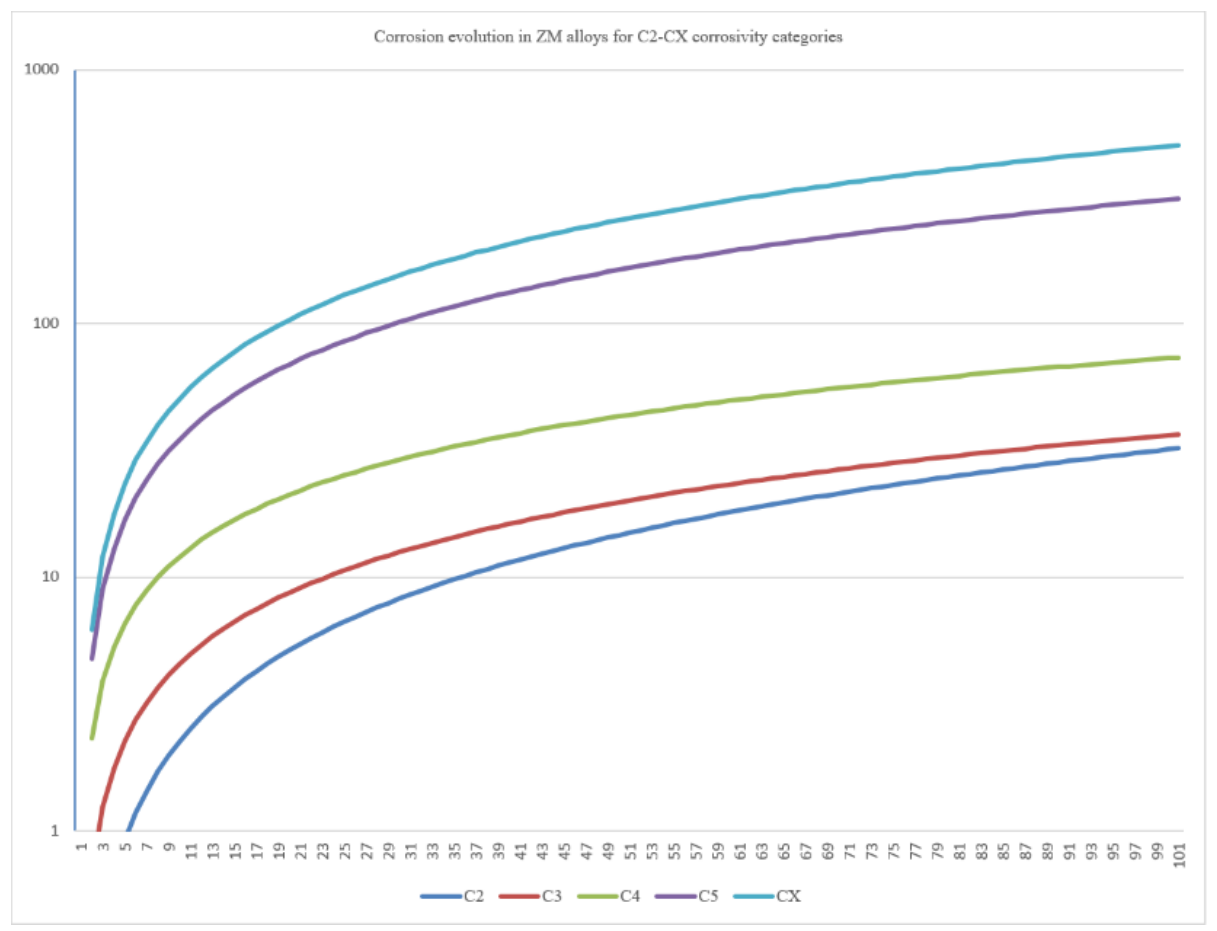

Figure 10: Corrosion evolution in ZM alloys for C2-CX corrosivity class ( $\mu \mathrm{m}$ vs years)

\subsection{Structure characterization of $\mathrm{ZM}$ alloys}

Conventional galvanized is normally made in pure zinc and a small part of aluminium ( $\mathrm{Zn}-\sim 0.2 \% \mathrm{Al})$. In the last three decades, coated steel sheets have been developed through a hot dip process in continuous galvanizing lines and are currently in use like galvannealed $(\mathrm{Zn}-\sim 10 \% \mathrm{Fe})$, galvalume (55\% $\mathrm{Al}-43.5 \%$ $\mathrm{Zn}-1.5 \% \mathrm{Si}$ ), Galfan ( $\mathrm{Zn}-5 \% \mathrm{Al})$, arriving to $\mathrm{ZM}$ alloys that also combine the presence of magnesium.

Typical micro- structures of ZM coatings (Zn-Al-Mg) include three main phases e.g., primary zinc with small amount of aluminium, binary eutectic $\mathrm{MgZn}_{2}-\mathrm{Zn}$ and ternary eutectic aluminium.

Structure characterization of the zinc-aluminium-magnesium (ZM) alloys, according to Salgueiro (Salgueiro Azevedo, Allély, Ogle, \& Volovitch, 2015a) is represented in Figure 11, where the ternary eutectic microstructures system is based in $\mathrm{Zn}-\mathrm{Al}-\mathrm{Zn}_{2} \mathrm{Mg}$ and binary eutectic in $\mathrm{Zinc}-\mathrm{Zn}_{2} \mathrm{Mg}$.

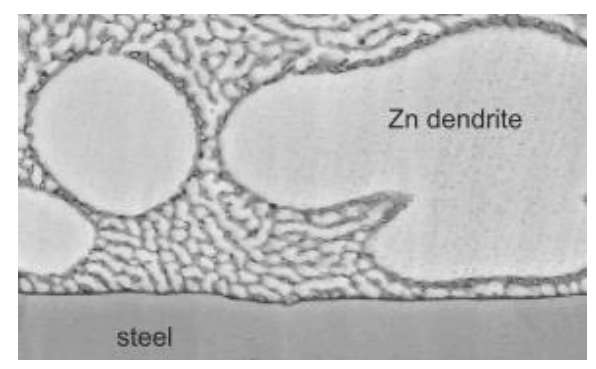

a 


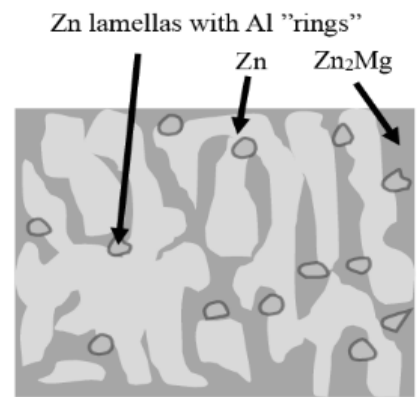

b

Figure 11: Characterization of the uncorroded $\mathrm{Zn}-\mathrm{Mg}-\mathrm{Al}$ coating: (a) General structure; (b) High resolution figure representing the detailed microstructure of the ternary eutectic

Other papers state also this structure characterization, highlighting how the percentage amount of magnesium and aluminium, and their ternary mix $\mathrm{Zn}-\mathrm{Mg}-\mathrm{Al}$ in the coating, can also affect hardness and corrosion resistance, as it will be deeply seen in the next paragraph (Dutta, Halder, \& Singh, 2010), (Hosking, Ström, Shipway, \& Rudd, 2007), (LeBozec, Thierry, Persson, Riener, \& Luckeneder, 2019).

\subsection{Corrosion behaviour and corrosion products characterization}

Companies producing zinc-aluminium-magnesium (ZM), zinc-aluminium (ZA) and aluminium-zinc (AZ) alloys claim its good corrosion performance in front of zinc (Z), mostly based in Neutral Salt Spray tests (ISO (International Organization for Standardization), 2015), like Stahl ${ }^{\circledR}$, shown in Figure 12 (Stahl, 2013).

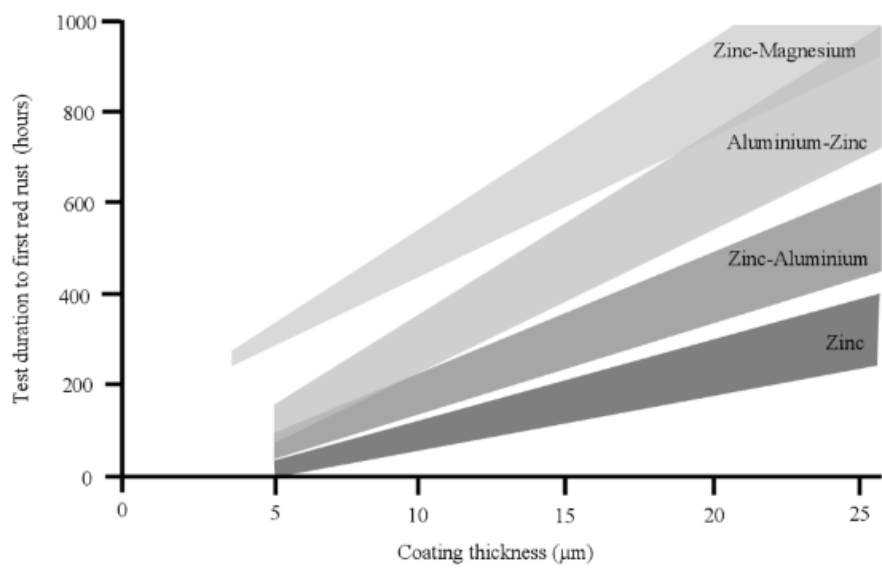

Figure 12: NSST corrosion resistance of Z and ZM materials

According to this manufacturer, the zinc-magnesium complex, forms a solid barrier layer. Reaction of oxygen and iron is slowed and creates a barrier effect on cut edges, as can be observed in Figure 13 (Stahl, 2013): 


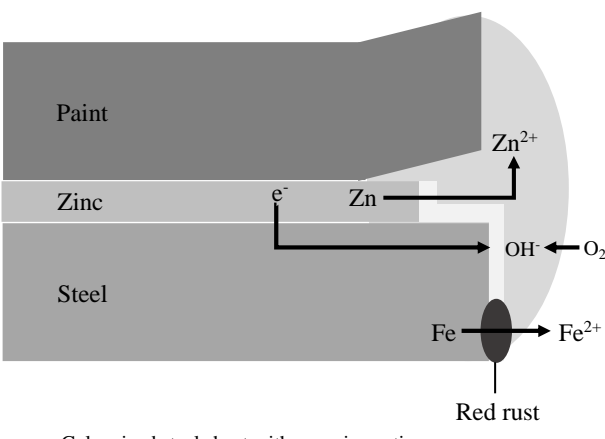

Galvanized steel sheet with organic coating

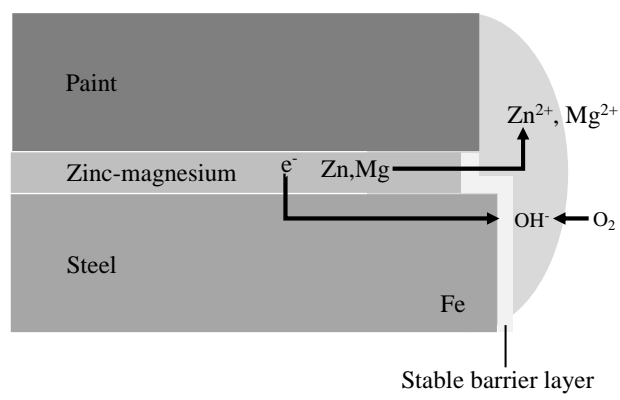

Zinc-Magnesium coated steel sheet with organic coating

Figure 13: Barrier layer effects creation in ZM materials

Arcelor Mittal ${ }^{\circledR}$, one of the most relevant manufacturers of these types of alloys, claims those features in a similar way as well: "Aluminium corrodes more slowly than zinc in most atmospheres because of its barrier layer of very passive aluminium oxide. However, this passive layer prevents aluminium from adequately contributing towards cathodic (sacrificial) protection. Cathodic protection is the strong point of zinc coatings, so if the coating is cut or scratched, the zinc near the exposed area will corrode first. The zincaluminium alloy combines the strength of both zinc and aluminium, giving better passive barrier protection than regular galvanize, and better sacrificial protection than alloy coatings with lower zinc composition" (Arcelor Mittal, 2013b).

In this sense, also crucial in the corrosion process is the protective effect of the corrosion products. Their composition and appearance along the process are key in determining the corrosion resistance. According to a specific research work to investigate corrosion products on ZM alloys (Tomas Prosek, Persson, Stoulil, \& Thierry, 2014a; Schürz et al., 2010), it was determined that corrosion products on ZM coated steel consist mainly of hydrozincite, $\mathrm{Zn}_{5}(\mathrm{OH})_{6}\left(\mathrm{CO}_{3}\right)_{2}$; zinc carbonate, $\mathrm{ZnCO}_{3}$ and zinc hydroxide, $\mathrm{Zn}(\mathrm{OH})_{2}$; with additions of simonkolleite, $\mathrm{Zn}_{5}(\mathrm{OH})_{8} \mathrm{Cl}_{2} \cdot \mathrm{H}_{2} \mathrm{O}$ and a carbonate-containing magnesium species.

In the same line, other research works (Hosking et al., 2007; Keppert, Luckeneder, Stellnberger, Mori, \& Antrekowitsch, 2014; T. Prosek, Nazarov, Bexell, Thierry, \& Serak, 2008; Tomas Prosek et al., 2014a; Salgueiro Azevedo, Allély, Ogle, \& Volovitch, 2015b; Schuerz et al., 2009a), stated that "magnesium accelerates the formation of a dense corrosion product, Zinc chloride hydroxide monohydrate, also called simonkolleite, which is extremely stable". It plays a key role as a corrosion inhibitor for the base metal.

Many studies also highlight the importance of LDH (Layered Double Hidroxide). These studies (Jing, Dong, Raza, Zhang, \& Zhang, 2021) revealed the appearance of 2 main layers: (1) Cathodic layer: divalent and trivalent cations; (2) Anodic layer: organic and inorganic anions, which specific structure provides an special inhibition against corrosion. Thus, composition is made of:

- $\quad \mathrm{M}(\mathrm{II})_{\mathrm{x}} \mathrm{M}(\mathrm{III})_{\mathrm{y}}(\mathrm{A})_{\mathrm{m}}(\mathrm{OH})_{\mathrm{n}} \cdot \mathrm{zH}_{2} \mathrm{O}$

- $\mathrm{M}(\mathrm{II})=\mathrm{Zn}^{2+},\left(\mathrm{Mg}^{2+)}\right.$

- $\mathrm{M}(\mathrm{III})=\mathrm{Al}^{3+}$

- $\mathrm{A}=\mathrm{CO}_{3}^{2-}, \mathrm{Cl}^{-}, \mathrm{SO}_{4}^{2-}$

First LDH discovered was Hydrotalcite, composed of $\mathrm{Mg}^{+2}, \mathrm{Al}^{+3} \mathrm{y} \mathrm{CO}_{3}^{-2}\left(\mathrm{Mg}_{6} \mathrm{Al}_{2} \mathrm{CO}_{3}(\mathrm{OH})_{16} \cdot 4 \mathrm{H}_{2} \mathrm{O}\right)$.

It is proven that ZM alloys have a very good performance in sodium chloride-containing atmospheres, due to the transformation of the ZM coating into a stable aluminium-rich oxide layer, which adheres on the steel substrate and protects it against corrosive attack (Schuerz et al., 2009b). Autocoat ${ }^{\circledR}$, in a specific research work (Autocoat, 2013), also demonstrated this fact by carrying out accelerated corrosion tests based on different standards from the automotive sector and the regular ISO 9227 neutral salt spray test (ISO (International Organization for Standardization), 2012b). As can be clearly seen in Table 7, the higher chloride load in the test, the higher ZM performance, measured as time to reach red rust. 
Table 7: Time to red rust appearance as a function of testing conditions in weeks

\begin{tabular}{lllll} 
Open & $\begin{array}{l}\text { Weekly chloride } \\
\text { load }\left(\mathrm{mg} / \mathrm{cm}^{2}\right)\end{array}$ & $\begin{array}{l}\mathrm{HDG}^{(*)} \\
7 \mu \mathrm{m}\end{array}$ & $\begin{array}{l}\mathrm{ZM} \\
7 \mu \mathrm{m}\end{array}$ & ZM / HDG \\
\hline Volvo test & 4,5 & 3 & 5 & 1,7 \\
New VDA test & 1,35 & 1,5 & 3 & 2 \\
Renault ECC1 test & 1 & 2 & 6 & 3 \\
VDA test & 13,6 & 1,5 & 12 & 8 \\
Neutral salt spray test & 90 & 0,6 & 8 & 13 \\
\hline HDG: Hot Dip Galvanized (zinc-based coating) & &
\end{tabular}

However, for other environments with other types of pollutants, the behaviour varies, and the differences in performance are not so obvious, as will be seen later. That's why, regular Neutral Salt Spray test (NSST) (ISO (International Organization for Standardization), 2012b), which has a very high chlorine load, at present is not considered valid to check corrosion resistance in general. In addition, these tests are done in a continuous mode (continuous sprayed water during the entire duration of the test), which causes that corrosion products cannot be generated.

To avoid this, other types of accelerated corrosion tests has been developed, led mostly by the automotive sector, such as cyclic NSS tests, like is the case of Renault ${ }^{\circledR}$ D17 2028/--C / ECC1 cycles (Renault, 2007), Volvo STD1027,3371 (Volvo, 2010a), Volvo STD1027 (Volvo, 2010b), Volvo STD423 (V. Group, 2009). In this way, Galvazinc and Cetim (Galvazinc \& Cetim, 2014) performed this type of test, using the referred Volvo ${ }^{\circledR}$ higher acid content test, in which 10 cycles of $24 \mathrm{~h}$ each, were done in a $\mathrm{SO}_{2}$ atmosphere and where the corrosion resistance, measured in zinc losses $(\mu \mathrm{m})$, was slightly higher than standard post-galvanization. Table 8 shows the time distribution for one cycle and the test conditions:

Table 8: $24 \mathrm{~h}$ cycle time distribution in Volvo ${ }^{\circledR}$ test according to STD1027

\begin{tabular}{|c|c|}
\hline $\begin{array}{l}24 \text { h cycle time } \\
\text { distribution }(\mathrm{h})\end{array}$ & Conditions \\
\hline 4 & $50^{\circ} \mathrm{C}$ \\
\hline 2 & $35^{\circ} \mathrm{C}$ and $100 \% \mathrm{RH}^{(*)}$ \\
\hline 2 & $\begin{array}{c}\mathrm{SO}_{2} \text { cabin at } 35^{\circ} \mathrm{C}-\mathrm{SO}_{2} \\
\text { injected: } 2 \text { litres }\end{array}$ \\
\hline 16 & $-30^{\circ} \mathrm{C}$ \\
\hline
\end{tabular}

Table 9 shows the final corrosion results expressed in mass loss:

Table 9: Corrosion results expressed in coating mass loss for each material tested by Galvazinc \& Cetim in Volvo test according to STD1027

\begin{tabular}{|c|c|}
\hline Material tested & Coating mass loss $(\mu \mathrm{m})$ \\
\hline Regular pre-galvanized Z275 & 8,16 \\
\hline HDG post-galvanized & 10,2 \\
\hline HDG + Oxide & No observed losses \\
\hline ZM120 Magnelis ${ }^{\circledR}$ & 11,52 \\
\hline
\end{tabular}

Looking at the tests results, it can be stated that ZM coatings have in general, a good performance in harsh atmospheres with high humidity and high chloride load, but this performance is less obvious in $\mathrm{SO}_{2} /$ acid atmospheres or with low humidity. On the other hand, it is also important to mention that more and more, in many countries, mostly from advanced economies, the level of $\mathrm{SO}_{2}$ emissions has been drastically reduced, while $\mathrm{NO}_{\mathrm{x}}$ emissions have increased (Stockholm-Environment and health administration, 2006). Finally, some publications also mention that in low $\mathrm{CO}_{2}$ atmospheres, $\mathrm{ZM}$ coatings are more affected in terms of corrosion than pure zinc coatings (Bozec, Thierry, Persson, \& Stoulil, 2018; LeBozec et al., 2013; Tomas Prosek, Persson, Stoulil, \& Thierry, 2014b). 


\subsection{Relevant international standards covering $\mathrm{ZM}$ coatings}

\subsubsection{Standards to classify environments and corrosivity categories}

With the exception of zinc-based metal coatings, for which the ISO 9223 standard (ISO, 2012) (CEN (European Committee for Standardization), 2012) and their corresponding parts, offer estimations of the corrosion rate for different environments, classified by corrosivity category (C1-CX), there is no standard at present with similar information, in terms of estimated corrosion rates for finishes based on ZM alloys. Therefore, in the present clause, only a summary of the aforementioned standards and their scope will be cited and briefly explained:

a) ISO 9223: Corrosion of metals and alloys. Corrosivity of atmospheres. Classification, determination and estimation (ISO, 2012).

The scope of this standard states:

"This International Standard establishes a classification system for the corrosivity of atmospheric environments. It:

- defines corrosivity categories for the atmospheric environments by the first-year corrosion rate of standard specimens,

- gives dose-response functions for normative estimation of the corrosivity category based on the calculated first-year corrosion loss of standard metals, and

- makes possible an informative estimation of the corrosivity category based on knowledge of the local environmental situation."

"...specifies the key factors in the atmospheric corrosion of metals and alloys. These are the temperaturehumidity complex, pollution by sulphur dioxide and airborne salinity".

It is the main ISO standard for zinc coatings corrosion classification of atmospheres and it establishes corrosivity categories, from $\mathrm{C} 1$ to $\mathrm{CX}$, as shown in Table 10:

Table 10: ISO atmosphere corrosivity categories

\begin{tabular}{cc} 
Category & Corrosivity \\
\hline C1 & Very low \\
C2 & Low \\
C3 & Medium \\
C4 & High \\
C5 & Very high \\
CX & Extreme \\
\hline
\end{tabular}

It also gives an approximation on what the corrosion rates could be for a first-year exposure, based in the type of environment (Table 11):

Table 11: Corrosion rates for zinc, $r_{c o r r}$, expressed in $\mu \mathrm{m} \cdot a^{-1}$ for the first year of exposure for the different corrosivity categories ISO 9223

\begin{tabular}{cl} 
Corrosivity category & $r_{\text {corr }}\left(\mu \mathrm{m} \cdot a^{-1}\right)$ \\
\hline C1 & $r_{\text {corr }} \leq 0.1$ \\
C2 & $0.1<r_{\text {corr }} \leq 0.7$ \\
C3 & $0.7<r_{\text {corr }} \leq 2.1$ \\
C4 & $2.1<r_{\text {corr }} \leq 4.2$ \\
C5 & $4.2<r_{\text {corr }} \leq 8.4$ \\
CX & $8.4<r_{\text {corr }} \leq 25$ \\
\hline
\end{tabular}

Finally, in a more subjective way, the standard facilitates a specific table in its annex C (see Table 12) that compiles a description of each corrosivity category, by describing the typical environments for each of them. This can be very useful when a subjective classification is sufficient to classify a given location. 
Table 12: Description of typical atmospheric environments related to the estimation of corrosivity categories (Source: ISO 9223)

\begin{tabular}{|c|c|c|c|}
\hline \multirow{2}{*}{$\begin{array}{c}\text { Corrosivity } \\
\text { category }\end{array}$} & \multirow[t]{2}{*}{ Corrosivity } & \multicolumn{2}{|c|}{ Typical environments - Examples $^{\mathrm{b}}$} \\
\hline & & Indoor & Outdoor \\
\hline $\mathrm{C} 1$ & Very low & $\begin{array}{l}\text { Heated spaces with low relative } \\
\text { humidity and insignificant pollution, } \\
\text { e.g., offices, schools, museums }\end{array}$ & $\begin{array}{l}\text { Dry or cold zone, atmospheric } \\
\text { environment with very low pollution and } \\
\text { time of wetness, e.g., certain deserts, } \\
\text { Central Arctic/Antarctica }\end{array}$ \\
\hline $\mathrm{C} 2$ & Low & $\begin{array}{l}\text { Unheated spaces with varying } \\
\text { temperature and relative humidity. Low } \\
\text { frequency of condensation and low } \\
\text { pollution, e.g., storage, sport halls }\end{array}$ & $\begin{array}{l}\text { Temperate zone, atmospheric } \\
\text { environment with low pollution }\left(\mathrm{SO}_{2}<5\right. \\
\left.\mu \mathrm{g} / \mathrm{m}^{3}\right) \text {, e.g., rural areas, small towns } \\
\text { Dry or cold zone, atmospheric } \\
\text { environment with short time of wetness, } \\
\text { e.g., deserts, subarctic areas }\end{array}$ \\
\hline C3 & Medium & $\begin{array}{l}\text { Spaces with moderate frequency of } \\
\text { condensation and moderate pollution } \\
\text { from production process, e.g., food- } \\
\text { processing plants, laundries, breweries, } \\
\text { dairies }\end{array}$ & $\begin{array}{l}\text { Temperate zone, atmospheric } \\
\text { environment with medium pollution }\left(\mathrm{SO}_{2} \text { : }\right. \\
\left.5 \mu \mathrm{g} / \mathrm{m}^{3} \text { to } 30 \mu \mathrm{g} / \mathrm{m}^{3}\right) \text { or some effect of } \\
\text { chlorides, e.g., urban areas, coastal areas } \\
\text { with low deposition of chlorides } \\
\text { Subtropical and tropical zone, atmosphere } \\
\text { with low pollution }\end{array}$ \\
\hline $\mathrm{C} 4$ & High & $\begin{array}{l}\text { Spaces with high frequency of } \\
\text { condensation and high pollution from } \\
\text { production process, e.g., industrial } \\
\text { processing plants, swimming pools }\end{array}$ & $\begin{array}{l}\text { Temperate zone, atmospheric } \\
\text { environment with high pollution }\left(\mathrm{SO}_{2}: 30\right. \\
\mu \mathrm{g} / \mathrm{m} 3 \text { to } 90 \mu \mathrm{g} / \mathrm{m} 3) \text { or substantial effect } \\
\text { of chlorides, e.g., polluted urban areas, } \\
\text { industrial areas, coastal areas without } \\
\text { spray of salt water or, exposure to strong } \\
\text { effect of de-icing salts } \\
\text { Subtropical and tropical zone, atmosphere } \\
\text { with medium pollution }\end{array}$ \\
\hline $\mathrm{C} 5$ & Very high & $\begin{array}{l}\text { Spaces with very high frequency of } \\
\text { condensation and/or with high pollution } \\
\text { from production process, e.g., mines, } \\
\text { caverns for industrial purposes, } \\
\text { unventilated sheds in subtropical and } \\
\text { tropical zones }\end{array}$ & $\begin{array}{l}\text { Temperate and subtropical zone, } \\
\text { atmospheric environment with very high } \\
\text { pollution }\left(\mathrm{SO}_{2}: 90 \mu \mathrm{g} / \mathrm{m}^{3} \text { to } 250 \mu \mathrm{g} / \mathrm{m}^{3}\right) \\
\text { and/or significant effect of chlorides, e.g., } \\
\text { industrial areas, coastal areas, sheltered } \\
\text { positions on coastline }\end{array}$ \\
\hline $\mathrm{CX}$ & Extreme & $\begin{array}{l}\text { Spaces with almost permanent } \\
\text { condensation or extensive periods of } \\
\text { exposure to extreme humidity effects } \\
\text { and/or with high pollution from } \\
\text { production process, e.g., unventilated } \\
\text { sheds in humid tropical zones with } \\
\text { penetration of outdoor pollution } \\
\text { including airborne } \\
\text { chlorides and corrosion-stimulating } \\
\text { particulate matter }\end{array}$ & $\begin{array}{l}\text { Subtropical and tropical zone (very high } \\
\text { time of wetness), atmospheric } \\
\text { environment with very high } \mathrm{SO}_{2} \text { pollution } \\
\text { (higher than } 250 \mu \mathrm{g} / \mathrm{m}^{3} \text { ) including } \\
\text { accompanying and production factors } \\
\text { and/or strong effect of chlorides, e.g., } \\
\text { extreme industrial areas, coastal and } \\
\text { offshore areas, occasional contact with salt } \\
\text { spray }\end{array}$ \\
\hline
\end{tabular}

NOTE 1 Deposition of chlorides in coastal areas is strongly dependent on the variables influencing the transport inland of sea salt, such as wind direction, wind velocity, local topography, wind sheltering islands outside the coast, distance of the site from the sea, etc.

NOTE 2 Extreme effect by chlorides, which is typical of marine splash or heavy salt spray, is outside of the scope of this International Standard.

NOTE 3 Corrosivity classification of specific service atmospheres, e.g., in chemical industries, is outside of the scope of this International Standard.

NOTE 4 Surfaces that are sheltered and not rain-washed in marine atmospheric environments where chlorides are deposited and cumulated can experience a higher corrosivity category due to the presence of hygroscopic salts. NOTE 5 A detailed description of types of indoor environments within corrosivity categories $\mathrm{C} 1$ and $\mathrm{C} 2$ is given in ISO 11844-1. Indoor corrosivity categories IC1 to IC5 are defined and classified.

a In environments with expected "CX category", it is recommended that the atmospheric corrosivity classification from one-year corrosion losses be determined.

b The concentration of sulfur dioxide $\left(\mathrm{SO}_{2}\right)$ should be determined during at least one year and is expressed as the annual average. 14 
b) ISO 9224: Corrosion of metals and alloys. Corrosivity of atmospheres. Guiding values for the corrosivity categories (CEN, 2012).

This standard shall be used in conjunction with ISO 9223. While ISO 9223 refers to corrosion values for the first year of exposure for the different C1-CX categories, ISO 9224 analyses those values for durations above one year.

It applies the master expression for corrosion processes, which obeys to Equation 1:

$$
C(t)=A \cdot t^{n}
$$

(Equation 1)

Where $t$ is the exposure time, expressed in years; $A$ is the corrosion rate experienced in the first year, expressed in grams per square metre per year $\left[\left(\mathrm{g} /\left(\mathrm{m}^{2} \cdot \mathrm{a}\right)\right]\right.$ or micrometers per year $\left(\mu \mathrm{m} \cdot \mathrm{a}^{-1}\right) ; n$ is the metalenvironment-specific time exponent, that depends on each metal and the particular atmospheric conditions (generally, $n<1$ ). There are guiding values in this standard for the $n$ parameter, represented as parameters $B 1$ and $B 2$. Table 13 shows these values for all materials under the scope of the standard. Values for zinc are highlighted in bold letter.

Table 13: Time exponent values for predicting and estimating corrosion attack. Source: ISO 9224 (Table 2)

\begin{tabular}{lll} 
Metal & B1 & B2 \\
\hline Carbon steel & 0,523 & 0,575 \\
Zinc & $\mathbf{0 , 8 1 3}$ & $\mathbf{0 , 8 7 3}$ \\
Cooper & 0,667 & 0,726 \\
Aluminium & 0,728 & 0,807 \\
\hline
\end{tabular}

According to ISO 9224 in cases where long-term metal loss data are available, it shall be used in Equation 1 the $\mathrm{n}$ value from this data. In cases where the detailed composition of the metal is not known, it must be selected the B1 value from Table 2 for the metal or alloy in question. This is the $\mathrm{n}$ value to be used in Equation 1. The B1 values were taken as the average time exponents from regression analyses of the flat panel long-term results of the ISO CORRAG atmospheric exposure programme (Dean \& Reiser, 2002; Knotkova et al., 1995, 2010). It is necessary to distinguish between metal-environment-specific time exponent, n, in Equation 1, estimated from exposure data, and B1 and B2 values assumed or calculated from the ISO CORRAG programme as generalized $b$ values. The B2 values in Table 2 include the two standard deviation additions and may be used where an upper limit of corrosion attack is desired when using the flat panel data from the ISO CORRAG programme.

c) ISO 9225: Corrosion of metals and alloys. Corrosivity of atmospheres. Measurement of environmental parameters affecting corrosivity of atmospheres (ISO (International Organization for Standardization), 2012a).

This standard determines the methodologies for the measurement of the parameters used to determine the type of atmospheric corrosivity, more specifically the humidity and temperature, the airborne pollutants and finally the $\mathrm{SO}_{2}$ and $\mathrm{Cl}^{-}$content.

d) ISO 9226: Corrosion of metals and alloys. Corrosivity of atmospheres. Determination of corrosion rate of standard specimens for the evaluation of corrosivity (CEN (European Committee for Standardization), 2012).

This standard determines the way to know the different corrosivity categories according to ISO 9223, through a one-year test, from which the loss of mass can be known and thus classify the corrosivity of the atmosphere according to table 2 of said norm.

Its scope states that "...this International Standard specifies methods which can be used for the determination of corrosion rate with standard specimens. The values obtained from the measurements (corrosion rates for the first year of exposure) are intended to be used as classification criteria for the evaluation of atmospheric corrosivity according to ISO 9223. They can also be used for informative evaluation of atmospheric corrosivity beyond the scope of ISO 9223".

e) ISO 12944-1: Corrosion protection of steel structures by protective paint systems. Part 1: General introduction (CEN (European Committee for Standardization), 1998).

It is a general introduction to the ISO 12944 series of standards, providing definitions and an introduction to each of the 8 parts in which the series is composed.

f) ISO 12944-2: Corrosion protection of steel structures by protective paint systems. Part 2: Classification of environments (CEN (European Committee for Standardization), 2017). 
This part refers to the environments related to the corrosivity categories, which have been based on the ISO 9223 standard previously mentioned (C1 to CX). Likewise, each one of these categories is defined, based on the mass loss during the first year of standard specimen, as it was done in the ISO 9223 standard (see Table 11).

\subsubsection{Standards to classify continuously hot-dip coated steel flat products for cold forming}

a) EN 10143: Continuously hot-dip coated steel sheet and strip - Tolerances on dimensions and shape (CEN, 2006).

This European Standard applies to continuously zinc (Z), zinc-iron alloy (ZF), zinc-aluminium alloy (ZA), aluminium-zinc alloy (AZ) and aluminium-silicon alloy (AS) hot-dip coated flat products made of low carbon and high strength steels for cold forming and of structural steels with a minimum thickness of 0,20 $\mathrm{mm}$ and a maximum thickness of $6,50 \mathrm{~mm}$, delivered as sheet, wide strip, slit wide strip or cut lengths obtained from slit wide strip or sheet.

Example of designation:

Sheet EN 10143 - 0,80Sx1200Sx2500FS

b) EN 10346: Continuously hot-dip coated steel flat products for cold forming. Technical delivery conditions (CEN, 2015).

This is the standard that regulates the standardized designations and supply conditions of sheets and strips with hot dip galvanization in continuous for subsequent cold deformation, for thicknesses between 0,2 and $3 \mathrm{~mm}$. The alloys based on zinc-aluminium / magnesium are those designated as ZA, AZ and ZM. However, the standard does not refer to other standards regarding corrosion of these finishes. In this way, it is important to bear in mind the definitions and composition that it makes in this regard and that are highlighted in Table 14.

Table 14: Composition of zinc/aluminium/magnesium alloys according to EN 10346

\begin{tabular}{cccccc} 
Alloy & Zn & $\mathrm{Al}$ & $\mathrm{Mg}$ & Si & Mischmetal \\
\hline ZA & Balance & $5 \%$ & - & - & Small amounts \\
ZM & Balance & $1,5 \% \leq(\mathrm{Al}+\mathrm{Mg}) \leq 8 \% ; \mathrm{Mg} \geq 0,2 \%$ & - & - \\
$\mathrm{AZ}$ & Balance & $55 \%$ & - & $1,6 \%$ & - \\
\hline
\end{tabular}

Example of designation:

Steel EN 10346 - DX53D+ZM100-M-B-O, where:

DX53D corresponds to the type of base material.

ZM100 identifies the type of coating and its mass $\left(100 \mathrm{~g} / \mathrm{m}^{2}\right.$ in the 2 faces of the coated surface).

M-B-O corresponds to the type of surface finish, in this case we talk about a minimized spangle zinc solidification way $(\mathrm{M})$, with an improved surface $(\mathrm{B})$ and oiled treated surface $(\mathrm{O})$.

Also, it is very useful to convert $\mathrm{g} / \mathrm{m}^{2}$ to $\mu \mathrm{m}$ per side through Equation 13 included in the referenced standard:

Equation 13: Conversion of thickness units (microns)- $\left(\mathrm{g} / \mathrm{m}^{2}\right)$

$$
\mathrm{t}_{\mathrm{z}}=\mathrm{m}_{\mathrm{z}} / 2 \mathrm{~d}
$$

(Equation 13)

Where, $t_{z}$ is the zinc coated thickness $(\mu \mathrm{m}) ; m_{z}$ is the zinc coating mass of both surfaces $\left(\mathrm{g} / \mathrm{m}^{2}\right)$ and $d$ is the zinc density $\left(\mathrm{g} / \mathrm{cm}^{3}\right)$, that for the case of ZM alloys used to be between 6,2 and $6,6 \mathrm{~g} / \mathrm{cm}^{3}$.

In this case, it is relevant to mention that maximum available thickness for a $\mathrm{ZM}$ alloy is around $35 \mu \mathrm{m}$, that corresponds to a ZM430 $\left(430 \mathrm{~g} / \mathrm{m}^{2}\right)$. Table 15 shows the different designations based in the mass coating in the actual edition of the standard: 
Table 15: Coating mass for Zinc (Z) and Zinc-magnesium alloy (ZM). Source: EN 10346 (Table 12)

\begin{tabular}{|c|c|c|c|c|}
\hline \multirow{2}{*}{$\begin{array}{l}\text { Coating } \\
\text { designation }\end{array}$} & \multirow{2}{*}{$\begin{array}{l}\text { Minimum total coating } \\
\text { mass }^{\mathrm{a}} \text {, both surfaces } \mathrm{g} / \mathrm{m}^{2}\end{array}$} & \multicolumn{2}{|c|}{$\begin{array}{l}\text { Theoretical guidance values for coating thickness per } \\
\text { surface in the single spot test }(\mu \mathrm{m})\end{array}$} & \multirow{2}{*}{$\begin{array}{l}\text { Density } \\
\left(\mathrm{g} / \mathrm{cm}^{3}\right)\end{array}$} \\
\hline & & Typical value ${ }^{\mathrm{b}}$ & Range & \\
\hline \multicolumn{5}{|c|}{ Zn coating masses $(\mathrm{Z})$} \\
\hline Z100 & 100 & 7 & 5 to 12 & \multirow{9}{*}{7,1} \\
\hline $\mathrm{Z} 140$ & 140 & 10 & 7 to 15 & \\
\hline $\mathrm{Z} 200$ & 200 & 14 & 10 to 20 & \\
\hline $\mathrm{Z} 225$ & 225 & 16 & 11 to 22 & \\
\hline $\mathrm{Z} 275$ & 275 & 20 & 13 to 27 & \\
\hline $\mathrm{Z} 350^{\mathrm{c}}$ & 350 & 25 & 17 to 33 & \\
\hline $\mathrm{Z} 450^{\mathrm{c}}$ & 450 & 32 & 22 to 42 & \\
\hline $\mathrm{Z} 600^{\mathrm{c}}$ & 600 & 42 & 29 to 55 & \\
\hline \multicolumn{4}{|c|}{ Zinc-magnesium alloy coating masses (ZM) } & \\
\hline ZM060 & 60 & 4,5 & 4 to 8 & \multirow{18}{*}{6,2 to $6,6^{\text {d }}$} \\
\hline ZM070 & 70 & 5,5 & 4 to 8 & \\
\hline ZM080 & 80 & 6 & 4 to 10 & \\
\hline ZM090 & 90 & 7 & 5 to 10 & \\
\hline ZM100 & 100 & 8 & 5 to 11 & \\
\hline ZM120 & 120 & 9 & 6 to 14 & \\
\hline ZM130 & 130 & 10 & 7 to 15 & \\
\hline ZM140 & 140 & 11 & 8 to 16 & \\
\hline ZM150 & 150 & 11,5 & 8 to 17 & \\
\hline $\mathrm{ZM} 160^{\mathrm{c}}$ & 160 & 12 & 8 to 17 & \\
\hline $\mathrm{ZM} 175^{\mathrm{c}}$ & 175 & 13 & 9 to 18 & \\
\hline ZM190' & 190 & 15 & 10 to 20 & \\
\hline $\mathrm{ZM} 200^{\mathrm{c}}$ & 200 & 15 & 10 to 20 & \\
\hline $\mathrm{ZM} 250^{\mathrm{c}}$ & 250 & 19 & 13 to 25 & \\
\hline $\mathrm{ZM} 300^{\mathrm{c}}$ & 300 & 23 & 17 to 30 & \\
\hline $\mathrm{ZM} 310^{\mathrm{c}}$ & 310 & 24 & 18 to 31 & \\
\hline $\mathrm{ZM} 350^{\mathrm{c}}$ & 350 & 27 & 19 to 33 & \\
\hline $\mathrm{ZM} 430^{\mathrm{c}}$ & 430 & 35 & 26 to 46 & \\
\hline
\end{tabular}

a See Equation 13: Conversion of thickness units (microns)- $(\mathrm{g} / \mathrm{m} 2)$

b Coating thicknesses can be calculated from the coating masses (see Equation 13). Thickness values obtained from calculations are for information only.

c Only steel grades in accordance with Tables 7 and 8 and LAD steel grades in accordance with Table 9.

${ }^{d}$ For determination of the thickness of ZM coatings, a density of 6,2 to $6,6 \mathrm{~g} / \mathrm{cm}^{3}$ can be used as orientation value for calculations.

e Not for multiphase steels.

c) JIS G 3323: Hot-dip zinc-aluminium-magnesium alloy-coated steel sheet and strip (JIS (Japanese Industrial standard), 2012).

This Japanese Industrial Standard specifies the steel sheet and strip and corrugated sheet manufactured by processing steel sheet into the shape and dimensions specified in JIS G 3316, which are coated to be of equal thickness on both surfaces by a hot-dip zinc-aluminium-magnesium alloy coating process. The zincaluminium-magnesium alloy composition by mass fraction is normally between 5,0-13,0\% of aluminium, 2,0-4,0\% of magnesium, $1,0 \%$ of other elements and the balance zinc.

Example of designation: Sheet SGMH 340

d) ASTM A1046: Standard Specification for Steel Sheet, zinc-aluminium-magnesium alloy-coated by the Hot-Dip Process (ASTM International, 2014).

This specification covers steel sheet in coils and cut lengths coated with zinc-aluminium-magnesium alloy by hot-dip process intended for applications requiring corrosion resistance and paintability. The steel sheet is produced in a number of designations, types, grades and classes designed to be compatible with differing application requirements. The coating bath composition and the method of estimating the coating thickness from the coating weight (mass) are given. Heat analysis of the base metal shall conform to the chemical requirements prescribed for carbon, manganese, phosphorous, sulphur, aluminium, copper, nickel, chromium, molybdenum, vanadium, columbium, and titanium. Bending properties of the base metal including minimum cold bending radio and cracks, and the coating bend test requirements are detailed.

Example of designation: Steel sheet CS Type A 


\subsubsection{Standard to classify steel wire products}

This corresponds to standard EN 10244-2: 2009: Steel wire and wire products. Non-ferrous metallic coatings on steel wire. Part 2: Zinc or zinc alloys coatings (CEN (European Committee for Standardization), 2009).

This part of the standard specifies the requirement for coating mass, other properties and testing of zinc and zinc alloy coatings on steel wire and steel wire products of circular or other section. The standard classifies the mass requirements for the different diameters' ranges, for zinc-based coatings and for aluminium alloys. It also proposes methods to test adherence and determine the mass of the coating; finally, there is a description of dipping test to check "... any significant eccentricity defect in the coating or any other significant uniformity defect...".

Example of designation: ZM Class A.

\subsubsection{Differences between standards in terms of aluminium and magnesium content}

According to the standards and designations referred in previous clauses, the different types of materials and coatings for zinc-aluminium-magnesium alloys can be summarized as described in Table 16:

Table 16: Most relevant metallic alloys alternative to traditional zinc-based coatings

\begin{tabular}{cll}
$\begin{array}{c}\text { Acronym } \\
\text { designation }\end{array}$ & \multicolumn{1}{c}{ Content } & \multicolumn{1}{c}{ Comments } \\
\hline $\mathrm{Z}$ & Minimum content of $99 \%$ & Standard protection \\
$\mathrm{ZF}$ & Between 8 to12\% Fe after annealing - Balance $\mathrm{Zn}$ & $\begin{array}{l}\text { Improved versus } \mathrm{Z} \\
\text { Improved } \mathrm{Z}+\text { drawing properties }\end{array}$ \\
$\mathrm{ZA}$ & $5 \%$ Aluminium - Balance $\mathrm{Zn}$ & $\begin{array}{l}\text { Good in acid/neutral atmospheres + } \\
\text { aesthetics }\end{array}$ \\
$\mathrm{ZM}$ & $55 \%$ Aluminium-1,6\% Si - Balance $\mathrm{Zn}$ & $\begin{array}{l}\text { Good in harsh environments and salt } \\
\text { atmospheres. Self-healing }\end{array}$ \\
& $0 \%<\mathrm{Al}<13 \%$ & $\begin{array}{l}\text { Good for high temperatures + good } \\
\text { formability }\end{array}$ \\
\hline
\end{tabular}

Figure 14 and Figure 15, show respectively, the band of aluminium and magnesium composition in the three key standards that classifies ZM finishes shown previously. It shows the difficulty to standardize accurately each quality designation, due to the big existent range in terms of content for each element of the alloy composition.

Example extracted from EN 10346: "Note 1 to entry: The composition of the bath is the sum of aluminium and magnesium from 1,5 to $8 \%$, containing minimum of $0,2 \%$ magnesium and the balance zinc".

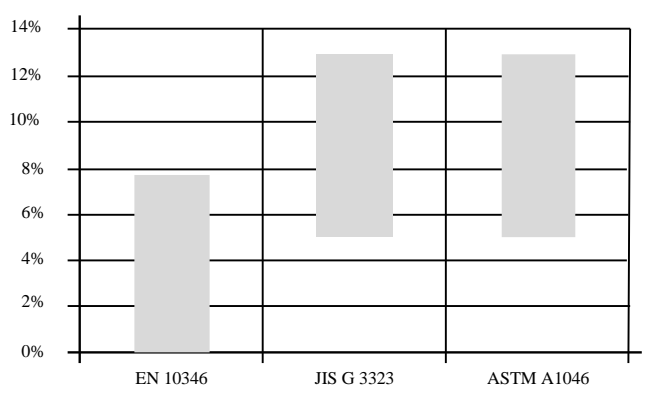

Figure 14: Aluminium content (\%) ranges according to the 3 main standards for ZM materials 


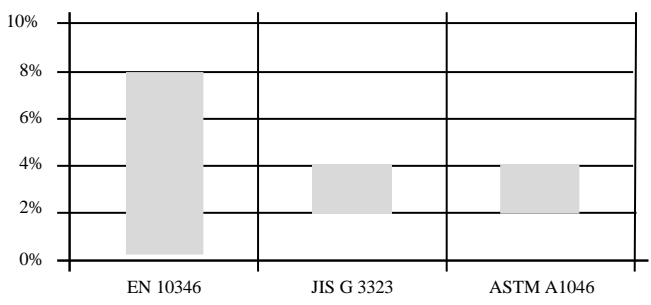

Figure 15: Magnesium content (\%) ranges according to the 3 main standards for ZM materials

\subsubsection{Product standard regarding cable trays systems}

This corresponds to IEC 61537: Cable management - Cable tray systems and cable ladder systems (IEC, 2006), which states: “...this International Standard specifies requirements and tests for cable tray systems and cable ladder systems intended for the support and accommodation of cables and possibly other electrical equipment in electrical and/or communication systems installations..."

Table 17 shows the classification system of the different zinc-based coatings (class 0 to 8 ) and the different stainless-steel qualities (9A to 9D).

Table 17: Classification for corrosion resistance according to IEC 61537

\begin{tabular}{|c|c|}
\hline Class & Reference-Material and finish \\
\hline $0^{\mathrm{a}}$ & None \\
\hline 1 & Electroplated to a minimum thickness of $5 \mu \mathrm{m}$ \\
\hline 2 & Electroplated to a minimum thickness of $12 \mu \mathrm{m}$ \\
\hline 3 & $\begin{array}{l}\text { Pre-galvanized to grade } 275 \text { to EN } 10327 \text { and } \\
\text { EN } 10326\end{array}$ \\
\hline 4 & $\begin{array}{l}\text { Pre-galvanized to grade } 350 \text { to EN } 10327 \text { and } \\
\text { EN } 10326\end{array}$ \\
\hline 5 & $\begin{array}{l}\text { Post-galvanized to a zinc mean coating } \\
\text { thickness (minimum) of } 45 \mu \mathrm{m} \text { according to } \\
\text { ISO } 1461 \text { for zinc thickness only }\end{array}$ \\
\hline 6 & $\begin{array}{l}\text { Post-galvanized to a zinc mean coating } \\
\text { thickness (minimum) of } 55 \mu \mathrm{m} \text { according to } \\
\text { ISO } 1461 \text { for zinc thickness only }\end{array}$ \\
\hline 7 & $\begin{array}{l}\text { Post-galvanized to a zinc mean coating } \\
\text { thickness (minimum) of } 70 \mu \mathrm{m} \text { according to } \\
\text { ISO } 1461 \text { for zinc thickness only }\end{array}$ \\
\hline 8 & $\begin{array}{l}\text { Post-galvanized to a zinc mean coating } \\
\text { thickness (minimum) of } 85 \mu \mathrm{m} \text { according to } \\
\text { ISO } 1461 \text { for zinc thickness only }\end{array}$ \\
\hline $9 \mathrm{~A}$ & $\begin{array}{l}\text { Stainless steel manufactured to ASTM: A } \\
\text { 240/A 240M - 95a designation S30400 or } \\
\text { EN10088 grade 1-4301 without a post- } \\
\text { treatment }^{\text {b }}\end{array}$ \\
\hline 9B & $\begin{array}{l}\text { Stainless steel manufactured to ASTM: A } \\
\text { 240/A 240M - 95a designation S31603 or } \\
\text { EN10088 grade 1-4404 without a post- } \\
\text { treatment }^{\text {b }}\end{array}$ \\
\hline $9 \mathrm{C}$ & $\begin{array}{l}\text { Stainless steel manufactured to ASTM: A } \\
\text { 240/A } 240 \mathrm{M}-95 \text { a designation S30400 or } \\
\text { EN10088 grade } 1-4301 \text { with a post-treatment }{ }^{\text {b }}\end{array}$ \\
\hline $9 \mathrm{D}$ & $\begin{array}{l}\text { Stainless steel manufactured to ASTM: A } \\
\text { 240/A 240M - 95a designation S31603 or } \\
\text { EN10088 grade } 1-4404 \text { with a post-treatment }{ }^{\text {b }}\end{array}$ \\
\hline \multicolumn{2}{|c|}{$\begin{array}{l}\text { a for materials which have no declared corrosion resistance } \\
\text { classification. } \\
\text { b the post-treatment process is used to improve the protection } \\
\text { against crevice crack corrosion and the contamination by other } \\
\text { steels. }\end{array}$} \\
\hline
\end{tabular}


On the other hand, this standard offers the possibility of obtaining the classification against corrosion, as an alternative to Table 17, by carrying out a salt spray chamber test. Table 18 shows the equivalence for each class with the corresponding hours of salt spray:

Table 18: Salt spray test duration according to IEC 61537

\begin{tabular}{cr}
$\begin{array}{c}\text { Class } \\
\text { (as detailed in Table 17) }\end{array}$ & Duration (h) \\
\hline 0 & - \\
1 & 24 \\
2 & 96 \\
3 & 155 \\
4 & 195 \\
5 & 450 \\
6 & 550 \\
7 & 700 \\
8 & 850 \\
\hline
\end{tabular}

The main issue of this 2006 standard (edition 2), is that ZM finishes withstand much more than class 8, since the corrosion test is based in neutral salt spray tests. So, it is not possible to classify them applying this standard. The new edition (edition 3) in which the IEC committee is working on (IEC, 2016), comprises extended corrosion classes: from Class 9 (1000 h in NSTT) to class 13 (>2500 h in NSTT). However, there are many discussions today about whether the salt spray test is the most appropriate to measure the corrosion resistance versus cyclic tests.

\subsection{Environmental claims in Zinc-Aluminium-Magnesium alloys}

ZM alloys manufacturers also claim the advantages of this type of coatings from environmental impact point of view. For instance, Arcelor Mittal ${ }^{\circledR}$ (Arcelor Mittal, 2018) highlights the positive environmental impact of their products based in this technology, from different perspectives: less usage of zinc than pure zinc coatings (for the same level of protection, ZM finishes uses much less zinc), less zinc runoff (rate of the dissolution of a material from its surface into the soil) to soils, lower environmental impact compared to other highly durable materials such stainless steel or aluminium, lower production of $\mathrm{CO}_{2}$ in the production process compared to aluminium of stainless steel, etc.

Figure 16 and Figure 17 represent graphically some of these statements:

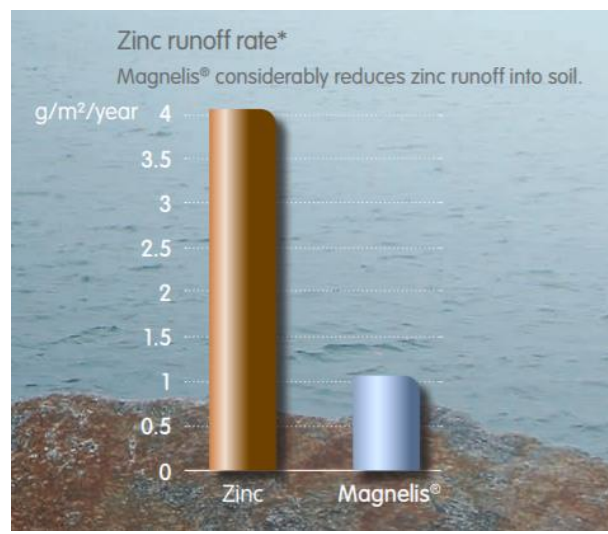

Figure 16: Zinc runoff rate. Source: (Source: Arcelor Mittal public brochure Magnelis book) 


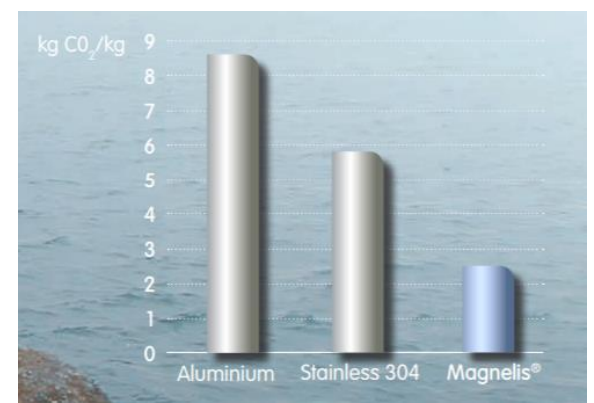

Figure 17: Production impact on $\mathrm{CO}_{2}$ emissions in Magnelis ${ }^{\circledR}$ production. (Source: Arcelor Mittal public brochure Magnelis book)

For is part, Tata steel $l^{\circledR}$ uses similar arguments with its brand MagiZinc ${ }^{\circledR}$ by stating that due to its material properties, our product allows the use of thinner coatings while maintaining the corrosion and stone chipping performance of the end product. This results in reduced zinc consumption and saves natural resources (Tata steel, 2016). Also, that reduced environmental impact-through extended product life and reduced raw material consumption or in the same way Sustainability The reduced coating thickness and long-term performance of MagiZinc ${ }^{\circledR}$ make it a sustainable choice. Fewer natural resources are used to deliver a coating with outstanding corrosion protection. The extended life of products made from MagiZinc ${ }^{\circledR}$ means longer replacement cycles - with associated savings in raw materials and energy consumption. Our steel is fully traceable and produced in accordance with ISO 14001 for environmental protection. We have adopted a class-leading framework for safety across our operations. We drive sustainability in our operations by focusing on manufacturing efficiency, safety, waste minimisation, carbon dioxide reduction and energy savings (Tata Corus, 2016).

Voestalpine $^{\circledR}$ also mention, in a very brief way, similar arguments in its brochure Corronder colofer brochures (Voestalpine, 2015): Conserve valuable resources. Valuable resources are sustainably conserved as a result of the reduced metallic coating thickness of Colofer ${ }^{\circledR}$ Corrender: Conservation of zinc as a natural resource, Increased sustainability, Preservation of the environment.

Even this type of arguments are written in a commercial way, it is obvious that for instance, a lower need of zinc to reach the same corrosion resistance, will have an undeniable positive impact on the environment, in the same way that it will have, a longer useful life of the products. Thus, if the performance of this alloys is proven in this way, this type of statements can be confirmed.

\subsection{Zinc-Aluminium-Magnesium alloys offered in the market}

Figure 18 shows the evolution in time of zinc-aluminium-magnesium alloys (Stahl, 2013). Today, there are many suppliers of ZM materials worldwide. Table 19 shows the main manufacturers, the product trademark and the main features of those products.

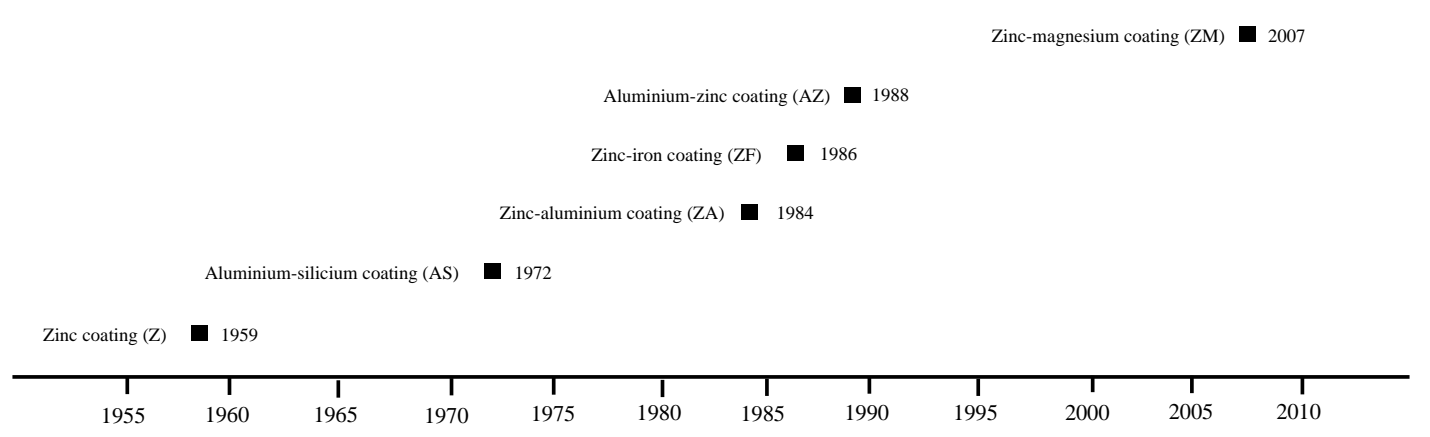

Figure 18: Evolution of metal alloys development in the European market 


\begin{tabular}{|c|c|c|c|c|c|c|c|}
\hline Raw material manufacturer $\left(\mathrm{RMM}^{1}\right)$ & Trade name & Designation & Zinc & Aluminium & Magnesium & Others & Declared corrosivity category \\
\hline Arcelor Mittal $^{\circledR}$ & Magnelis ${ }^{\circledR}$ & $\begin{array}{l}\text { Steel sheets or strips (Arcelor Mittal, 2013e, } \\
2018,2020 \mathrm{a})\end{array}$ & $94 \%$ & $3 \%$ & $3 \%$ & - & $\begin{array}{l}\text { C5-15 years } \\
\text { C5M-20 years } \\
>200 \mathrm{~h} / \mu \mathrm{m}\end{array}$ \\
\hline Arcelor Mittal $^{\circledR}$ & Zagnelis $^{\circledR} 15$ & $\begin{array}{l}\text { Steel sheets or strips (Arcelor Mittal, 2020b; } \\
\text { Rich Clausius \& Arcelor Mittal, n.d.) }\end{array}$ & $93.3 \%$ & $3.7 \%$ & $3 \%$ & - & N.D. ${ }^{1}$ \\
\hline Arcelor Mittal $^{\circledR}$ & Aluzinc $^{\circledR}$ & Steel sheets or strips (Arcelor Mittal, 2013a) & $43.4 \%$ & $55 \%$ & $0 \%$ & $1.6 \% \mathrm{Si}$ & $\begin{array}{l}\text { C4- } 15 \text { years } \\
\pm 100 \mathrm{~h} / \mu \mathrm{m}\end{array}$ \\
\hline Arcelor Mittal $^{\circledR}$ & $\mathrm{Crapal}^{\circledR} 2$ & Steel wire (Arcelor Mittal, 2013b, 2013c) & $95 \%$ & $5 \%$ & $0 \%$ & - & $1000 \mathrm{~h} \mathrm{NSS}^{1}$ \\
\hline Arcelor Mittal $^{\circledR}$ & $\mathrm{Crapal}^{\circledR} 4$ & Steel wire (Arcelor Mittal, 2013b) & $95 \%$ & $5 \%$ & $0 \%$ & - & 2000 h NSS $^{1}$ \\
\hline Arcelor Mittal $^{\circledR}$ & CrapalOptimum $^{\circledR}$ & Steel wire (Arcelor Mittal, 2013b) & $92 \%$ & $5 \%$ & $3 \%$ & - & $2500 \mathrm{~h} \mathrm{NSS}^{1}$ \\
\hline Arcelor Mittal $^{\circledR}$ & CrapalPremium $^{\circledR}$ & $\begin{array}{l}\text { Steel wire (Arcelor Mittal, 2012, 2013b, } \\
\text { 2016) }\end{array}$ & N.D. ${ }^{1}$ & N.D. ${ }^{1}$ & N.D. ${ }^{1}$ & N.D. ${ }^{1}$ & $\begin{array}{l}4000 \mathrm{~h} \mathrm{NSS}^{1} \\
\left(310 \mathrm{~g} / \mathrm{m}^{2}\right)\end{array}$ \\
\hline Arcelor Mittal $^{\circledR}$ & Crapal $^{\circledR}$ Color $^{7}$ & $\begin{array}{l}\text { Steel wire with pigmented organic coating } \\
\text { (Arcelor Mittal, 2013b, 2013d) }\end{array}$ & $92 \%$ & $5 \%$ & $3 \%$ & - & $2500 \mathrm{~h} \mathrm{NSS}^{1}$ \\
\hline Corus Tata ${ }^{\circledR}$ & Magizinc $^{\circledR}$ & $\begin{array}{l}\text { Steel sheets or strips } \\
\text { ZMA100 - ZMA200 (ZMA140 replacing } \\
\text { Z275) } \\
\text { (Tata Corus, 2009, 2010, 2012, 2016; Tata } \\
\text { steel, 2016) }\end{array}$ & $96.8 \%^{9}$ & $1.6 \% 9$ & $1.6 \% 9$ & $\begin{array}{l}\text { Pure Zinc } \\
\text { crystals } \\
\text { surrounded } \\
\text { by } \\
\mathrm{MgZn} 2 / \mathrm{Zn} \\
\text { and Al }\end{array}$ & $\begin{array}{l}1000 \div 1200 \text { h NSS }^{1} \\
\left(140 \mathrm{~g} / \mathrm{m}^{2}\right)\end{array}$ \\
\hline Mazzoleni $^{\circledR}$ & Galvalid $^{\circledR}$ & Steel wire (Mazzoleni, 2016) & $95 \%$ & $5 \%$ & - & $\begin{array}{l}\text { Misch } \\
\text { metals }\end{array}$ & $\begin{array}{l}500 \div 600 \mathrm{~h} \mathrm{NSS}^{1} \\
(15 \mu \mathrm{m})\end{array}$ \\
\hline Bekaert $^{\circledR}$ & Bezinal $^{\circledR}$ & Steel wire (Bekaert, n.d., 2018) & $95 \%$ & $5 \%$ & - & $\begin{array}{l}\text { Bekaert } \\
\text { know-how }\end{array}$ & $\begin{array}{l}1000 \mathrm{~h} \mathrm{NSS}^{1} \\
\left(75 \mathrm{~g} / \mathrm{m}^{2}\right)\end{array}$ \\
\hline Bekaert $^{\circledR}$ & Bezinal $^{\circledR} 2000$ & Steel wire (Bekaert, n.d., 2010a) & $95 \%$ & $5 \%$ & - & $\begin{array}{l}\text { Bekaert } \\
\text { know-how }\end{array}$ & $\begin{array}{l}2000 \mathrm{~h} \mathrm{NSS}^{1} \\
\left(75 \mathrm{~g} / \mathrm{m}^{2}\right)\end{array}$ \\
\hline Bekaert $^{\circledR}$ & Bezinal $^{\circledR} 3000$ & Steel wire (Bekaert, 2010b, 2017) & $95 \%$ & $5 \%$ & - & $\begin{array}{l}\text { Bekaert } \\
\text { know-how }\end{array}$ & $\begin{array}{l}5000 \text { h NSS }^{1}\left(\text { Class A }^{16}\right) \\
3000 \text { h NSS }^{1}\left(\text { Class B }^{16}\right)\end{array}$ \\
\hline Bekaert $^{\circledR}$ & Bezinal XC & Steel wire (Bekaert, 2014) & $95 \%$ & $5 \%$ & - & - & From 240 to $360 \mathrm{NSS}^{1}$ \\
\hline Salzgitter Flachstahl ${ }^{\circledR}$ & Stroncoat ${ }^{\circledR}$ & $\begin{array}{l}\text { Steel sheets or strips (Salzgitter Flachstahl, } \\
\text { 2014) }\end{array}$ & $96-98 \%$ & $1-2 \%$ & $1-2 \%$ & - & $\begin{array}{l}2 \text { to } 6 \text { times higher than } \\
\text { standard zinc coatings }\end{array}$ \\
\hline Salzgitter Flachstahl ${ }^{\circledR}$ & StronSal ${ }^{\circledR}$ & $\begin{array}{l}\text { Steel sheets or strips (Salzgitter Flachstahl, } \\
\text { 2016) }\end{array}$ & $96-98 \%$ & $1-2 \%$ & $1-2 \%$ & - & $\begin{array}{l}2 \text { to } 6 \text { times higher than } \\
\text { standard zinc coatings }\end{array}$ \\
\hline U.S. Steel Kosice ${ }^{\circledR}$ & Zinkomag $^{\circledR}$ & $\begin{array}{l}\text { Steel sheets or strips (U.S. Steel Kosice, } \\
\text { 2015; United States Steel Corporation (USS), } \\
\text { 2013) }\end{array}$ & $98.4-98 \%$ & $0.8-1 \%$ & $0.8-1 \%$ & - & $\begin{array}{l}200 \mathrm{~h} \mathrm{NSS}^{1} \text { until appearance } \\
\text { of red corrosion }\left(50 \mathrm{~g} / \mathrm{m}^{2} \text { per }\right. \\
\text { side })\end{array}$ \\
\hline U.S. Steel Kosice ${ }^{\circledR}$ & Zinkomag Plus ${ }^{\circledR}$ & $\begin{array}{l}\text { Steel sheets or strips (U.S. Steel Kosice, } \\
\text { 2015) }\end{array}$ & $96-96.4 \%$ & $1.8-2 \%$ & $1.8-2 \%$ & - & $\begin{array}{l}>1000 \mathrm{~h} \mathrm{NSS}^{1}\left(150 \mathrm{~g} / \mathrm{m}^{2} \text { per }\right. \\
\text { side })\end{array}$ \\
\hline Voelstalpine $^{\circledR}$ & Corrender $^{\circledR}$ & $\begin{array}{l}\text { Steel sheets or strips (Voestalpine, 2015, } \\
2016,2020 \text { ) }\end{array}$ & $96 \%$ & $2.5 \%$ & $1.5 \%$ & - & $\begin{array}{l}>1300 \text { h ZM90 NSS }{ }^{1} \\
\text { (Voestalpine, 2016) }\end{array}$ \\
\hline Voelstalpine $^{\circledR}$ & Colofer ${ }^{\circledR}$ Corrender & $\begin{array}{l}\text { Steel sheets or strips (Voestalpine, 2015), } \\
\text { (Voestalpine, 2016) }\end{array}$ & $96 \%$ & $2.5 \%$ & $1.5 \%$ & $\begin{array}{l}\text { Organic } \\
\text { coating } 10\end{array}$ & - \\
\hline One Steel ${ }^{\circledR}$ & Zalcote $^{\circledR}$ & Steel wire (OneSteel, 2016) & $95 \%$ & $5 \%$ & $0 \%$ & - & N.D. ${ }^{1}$ \\
\hline
\end{tabular}




\begin{tabular}{|c|c|c|c|c|c|c|c|}
\hline Maccaferri $^{\circledR}$ & Galmac $^{\circledR} 4 \mathrm{R}$ & Steel wire (Maccaferri, 2015) & $\begin{array}{l}\text { Not } \\
\text { referenced }\end{array}$ & $\begin{array}{l}\text { Not } \\
\text { referenced }\end{array}$ & $0 \%$ & $\begin{array}{l}\text { Misch } \\
\text { metals }^{11}\end{array}$ & $\approx 2500 \mathrm{~h} \mathrm{NSS}^{1}$ \\
\hline Posco $^{\circledR}$ (group Nisshin Steel) & PosMAC $^{\circledR 12}$ & Steel sheets or strips (Posco, n.d.) & $94.5 \%$ & $2.5 \%$ & $3 \%$ & - & $\begin{array}{l}\text { Superior to } 120 \text { cycles } \mathrm{NSS}^{1} \\
\left(140 \text { to } 275 \mathrm{~g} / \mathrm{m}^{2}\right)\end{array}$ \\
\hline Posco $^{\circledR}$ (group Nisshin Steel) & PosMAC $^{\circledR} 3.0$ & Steel sheets or strips (Posco, n.d., 2018) & $94.5 \%$ & $2.5 \%$ & $3 \%$ & - & $>2400 \mathrm{~h} \mathrm{NSS}^{1}$ \\
\hline $\begin{array}{l}\text { Nippon Steel corporation }{ }^{\circledR 12} \text { (group } \\
\text { Wheeling-Nipon Steel) }\end{array}$ & $\mathrm{ZAM}^{\circledR 12}$ & $\begin{array}{l}\text { Steel sheets or strips (Bertol, 2014; Nisshin } \\
\text { Steel, n.d.; Wheeling-Nipon steel, 2019a, } \\
\text { 2019b; Yao et al., 2016) }\end{array}$ & $91 \%$ & $6 \%$ & $3 \%$ & - & $\begin{array}{l}>2500 \mathrm{~h} \mathrm{NSS}^{1}(0,3 \mathrm{oz} / \mathrm{ft} 2 \mathrm{in} \\
\text { one side })\end{array}$ \\
\hline $\begin{array}{l}\text { Wheeling Nisshin }{ }^{\circledR 12} \text { (group Nisshin } \\
\text { Steel) }\end{array}$ & Galvalume $^{\circledR 13}$ & Steel sheets or strips (Nisshin Wheeling, n.d.) & $45 \%$ & $55 \%$ & $0 \%$ & - & $>2500 \mathrm{~h} \mathrm{NSS}^{1}$ \\
\hline USS $^{\circledR}$ (United States Steel Corporation) & Galvalume $^{\circledR}$ & $\begin{array}{l}\text { Steel sheets or strips (United States Steel } \\
\text { Corporation (USS), 2015) }\end{array}$ & $45 \%$ & $55 \%$ & $0 \%$ & Silicon ${ }^{14}$ & N.D. ${ }^{1}$ \\
\hline $\operatorname{Stahl}^{\circledR}$ & WZM Wupperman ${ }^{\circledR}$ & Steel sheets or strips (Stahl, 2013) & $\begin{array}{l}\text { Not } \\
\text { referenced }\end{array}$ & $\begin{array}{l}\text { Not } \\
\text { referenced }\end{array}$ & $\begin{array}{l}\text { Not } \\
\text { referenced }\end{array}$ & $\begin{array}{l}\text { Not } \\
\text { referenced }\end{array}$ & $\begin{array}{l}\text { Between } 800 \text { and } 1000 \mathrm{~h} \text { for } \\
\text { an average coating of } 20 \mu \mathrm{m}\end{array}$ \\
\hline Bluescope Steel $^{\circledR}$ & Zincalume $^{\circledR}$ & $\begin{array}{l}\text { Steel sheets or strips (Bluescope Steel, 2008, } \\
\text { 2013a, 2013b, 2020) }\end{array}$ & $43.5 \%$ & $55 \%$ & $0 \%$ & $1.5 \% \mathrm{Si}$ & $\begin{array}{l}4 \text { times more resistant than a } \\
\text { standard galvanized with the } \\
\text { same thickness. Tests } \\
\text { performed but results not } \\
\text { declared. }\end{array}$ \\
\hline Stramit $^{\circledR}-$ Building products & $\mathrm{ZAM}^{\circledR 12}$ & Steel sheets or strips (Stramit, 2012) & $91 \%$ & $6 \%$ & $3 \%$ & - & $\begin{array}{l}4 \text { times more resistant than a } \\
\text { standard galvanized with the } \\
\text { same thickness. NSS and mass } \\
\text { loss tests performed. }\end{array}$ \\
\hline Ruukki $^{\circledR}$ & Galfan $^{\circledR}$ & Steel sheets or strips & $\begin{array}{l}\text { Not } \\
\text { referenced }\end{array}$ & $\begin{array}{l}\text { Not } \\
\text { referenced }\end{array}$ & $\begin{array}{l}\text { Not } \\
\text { referenced }\end{array}$ & $\begin{array}{l}\text { Not } \\
\text { referenced }\end{array}$ & N.D. ${ }^{1}$ \\
\hline $\operatorname{SSAB}^{\circledR}$ & Aluzinc $^{\circledR}$ & $\begin{array}{l}\text { Steel sheets or strips (SSAB, 2016, 2020a, } \\
\text { 2020c, 2020d, 2020b) }\end{array}$ & $43.4 \%$ & $55 \%$ & $0 \%$ & $1.6 \% \mathrm{Si}$ & $\begin{array}{l}\mathrm{C} 4-15 \text { years } \\
\pm 100 \mathrm{~h} / \mu \mathrm{m}\end{array}$ \\
\hline $\begin{array}{l}\text { Technology derived from the project } \\
\text { "Galfan" } \\
\text { (See "Producers" } \\
\text { in:http://www.galfan.com/ }\end{array}$ & $\begin{array}{l}\text { Galfan }^{\circledR} \\
\text { (Galfan Technology } \\
\text { Center Inc., n.d.) }\end{array}$ & $\begin{array}{l}\text { Steel sheets or strips } \\
\text { Steel wire }\end{array}$ & $95 \%$ & $5 \%$ & $0 \%$ & - & $\begin{array}{l}\text { No detailed technical } \\
\text { information on corrosion } \\
\text { resistance is cited }\end{array}$ \\
\hline $\begin{array}{l}\text { Magni } \\
\text { http://magnicoatings.com/?lang=es }\end{array}$ & Magni $^{\circledR}$ & $\begin{array}{l}\text { Depending on application (see } \text { Magni }^{\circledR} \\
\text { webpage) (Magni, 2020) } \\
\text { (Technology applicable to parts and } \\
\text { accessories) }\end{array}$ & $\begin{array}{l}\text { Not } \\
\text { referenced }{ }^{4}\end{array}$ & $\begin{array}{l}\text { Not } \\
\text { referenced }{ }^{4}\end{array}$ & $0 \%$ & $\begin{array}{l}\text { Not } \\
\text { referenced }{ }^{4}\end{array}$ & $\begin{array}{l}\text { No detailed technical } \\
\text { information on corrosion } \\
\text { resistance is cited }\end{array}$ \\
\hline $\begin{array}{l}\text { Dacromet }{ }^{\circledR} \text { technology } \\
\text { (based in laminar zinc and aluminium } \\
\text { technology (zinc/aluminium flakes)) }\end{array}$ & $\begin{array}{l}\text { Dacromet }^{\circledR} \\
\text { Dacromet }^{\circledR} 320(\text { Grade A } \\
\text { and grade B })^{16} \\
\text { Dacromet }{ }^{\circledR} 500(\text { Grade A } \\
\text { and grade B })^{16} \\
\text { Dacroblack }^{\circledR} 15(12 \mu \mathrm{m})\end{array}$ & $\begin{array}{l}\text { Depending on the application and the } \\
\text { providers of this technology } 5 \text { (NOF Metal } \\
\text { Coatings Group, n.d.) } \\
\text { (Technology applicable to parts and } \\
\text { accessories) }\end{array}$ & $\begin{array}{l}\text { Not } \\
\text { referenced }\end{array}$ & $\begin{array}{l}\text { Not } \\
\text { referenced }\end{array}$ & $\begin{array}{l}\text { Not } \\
\text { referenced }\end{array}$ & $\begin{array}{l}\mathrm{Cr}^{+3} \text { ó } \mathrm{Cr}^{+6} \\
\text { passivated }\end{array}$ & $\begin{array}{l}\text { According to NOF Metal } \\
\text { coatings (N. metal coatings } \\
\text { Group, n.d.), for Dacromet }{ }^{\circledR} \\
320: \\
>240 \mathrm{~h} \text { w/o white corrosion, } \\
>600 \mathrm{~h} \text { w/o red corrosion } \\
\text { (Grade A) } \\
>240 \mathrm{~h} \text { w/o white corrosion, } \\
>1000 \mathrm{~h} \text { w/o red corrosion } \\
\text { (Grade B) }\end{array}$ \\
\hline $\begin{array}{l}\text { Geomet }^{\circledR} \text { Technology } \\
\text { (based in laminar zinc and aluminium } \\
\text { technology (zinc/aluminium flakes)) }\end{array}$ & 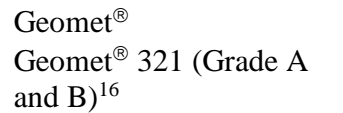 & $\begin{array}{l}\text { Depending on the application and the } \\
\text { providers of this technology }(\text { Galol S.A., n.d.- } \\
\text { b; NOF Metal Coatings Group, n.d., 2012) }\end{array}$ & $\begin{array}{l}\text { Not } \\
\text { referenced }\end{array}$ & $\begin{array}{l}\text { Not } \\
\text { referenced }\end{array}$ & $\begin{array}{l}\text { Not } \\
\text { referenced }\end{array}$ & $\begin{array}{l}\text { Chrome free } \\
\text { passivated }\end{array}$ & $\begin{array}{l}\text { According to NOF Metal } \\
\text { coatings / Galol (Galol S.A., } \\
\text { n.d.-b; NOF Metal Coatings }\end{array}$ \\
\hline
\end{tabular}


Tecnología Deltatone ${ }^{\circledR}$

Deltatone ${ }^{\circledR}$

(based in laminar zinc and aluminium

technology (zinc/aluminium flakes))

BIEC International Inc ${ }^{13}$

http://www.galvalume.com

Galvalume $^{\circledR}$

\section{ThyssenKrupp $^{\circledR}$}

Nippon steel \& Sumitomo Metal

corporation

http://www.nssmc.com/en/product/sheet/s
Depending on the application and the No providers of this technology ${ }^{6}$ (Galol S.A., n.d.- referenced a; Microcapas, 2020)

(Technology applicable to parts and accessories)

Depending on the application and the 45\% providers of this technology (BIEC, 2016)

Coating mass between 70 and $300 \mathrm{~g} / \mathrm{m}^{2} \quad 99 \%$

(ThyssenKrupp Steel Europe, 2015)

Coating weight K18 (Bluescope Steel, 2018) $\quad 86 \%$

\section{ZM Ecoprotect ${ }^{\circledR}$}

SuperDyma ${ }^{\mathrm{TM}}$
Not

referenced

Admits

post-

treatments

(Delta-

seal $^{\circledR}$,

Delta-seal

$\left.\mathrm{GZ}^{\circledR} \ldots\right)$

$55 \%$

$0 \%$

$-$

$11 \%$

Trace
Group, 2012), para Geomet ${ }^{\circledR}$ $321:$

$>240 \mathrm{~h}$ w/o white corrosion,

$>720 \mathrm{~h}$ w/o red corrosion

$\left(>24 \mathrm{~g} / \mathrm{m}^{2}\right)$

$>1000 \mathrm{~h}$ w/o red corrosion $\left(>36 \mathrm{~g} / \mathrm{m}^{2}\right)$

Between $480 \mathrm{~h}$ and $960 \mathrm{~h}$ ( 8

and $12 \mu \mathrm{m}$ ), test NSS ISO

9227

Deltatone $^{\circledR} 9000$

(Galol S.A., n.d.-a;

Microcapas, 2020)

30 years before the first appearance of red corrosion, according to BIEC (BIEC,

2016)

NSS $^{1} 1000$ h ZM140

amount of

SSi
Salt Spray Test $2000 \mathrm{H}$

Cycling corrosion test (JASO

M609-91method) 180 cycles

uperdyma_introduction.html

RMM: Raw Material Manufacturer: N.D.: Not declared; NSS: Neutral Salt Spray test

2 According to IEC 61537 Edition 3 Committee draft (IEC, 2016)

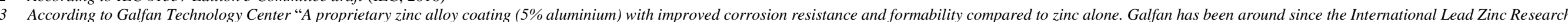

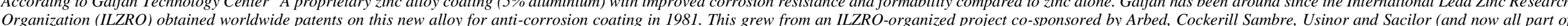

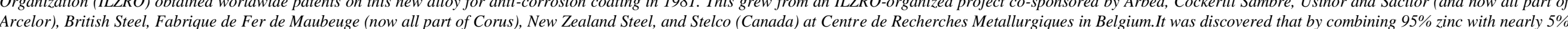

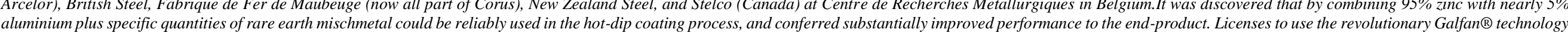

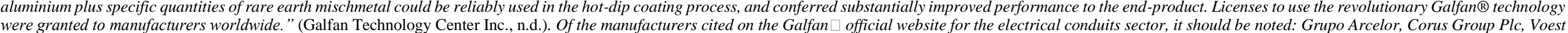
were granted to manufacturers wo

4 Magni $^{\circledR}$ does not specify in its technical information the detailed composition of its coatings, although the most frequent refer to zinc-based coatings with an organic "Top" layer based on aluminium.

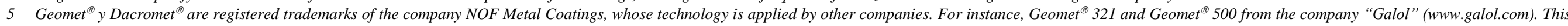

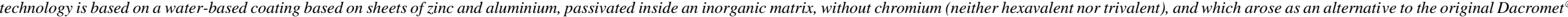
eliminating the use of Chromium, in compliance with the European Directives ReACH and RoHS (Galol S.A., n.d.-b).

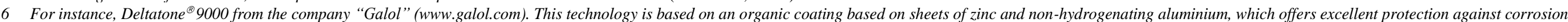
(Galol S.A., n.d.-a). It is a non-electrolytic protection system, for all types of metal parts, threaded or not, especially steel parts.

7 Crapal $^{\circledR}$ finishes coated with a layer of pigmented resin to prevent the fall of zinc oxides into the earth. Used primarily for agricultural use or to offer different aesthetics (Arcelor Mittal, 2013b).

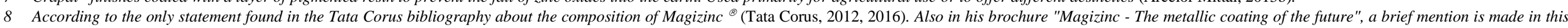
way: "MagiZinc is a zinc coating that incorporates a small fraction of magnesium and aluminium" (Tata Corus, 2010).

9 According to the internal report of Tata Corus 2007-2008 (Tata Corus, 2009). This information is not publicized in the official Magizinc ${ }^{\circledR}$ technical brochures

10 According to Voelstalpine brochure (Voestalpine, 2015) for which no information is offered about the content of the additional organic coating of Colofer ${ }^{\circledR}$ Corrender.

11 According to Maccaferri brochure (Maccaferri, 2015): The GalMac ${ }^{\circledR} 4 R$ coating also has the presence of "MischMetals" (MM) that allow a more authentic bond between Zinc (Zn) and Aluminium (Al).

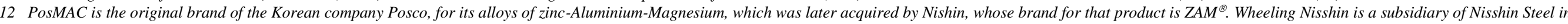
the United States, following the acquisition of the wheeling company group. Stramit also markets this product.

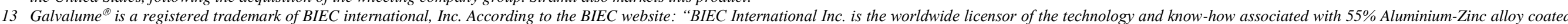

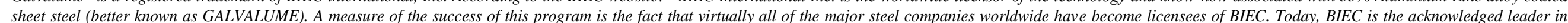
technologies associated with 55\% Al-Zn coated sheet Steel"(BIEC, 2016).

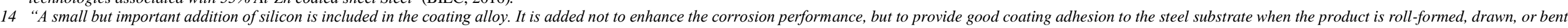


during fabrication" (United States Steel Corporation (USS), 2015).

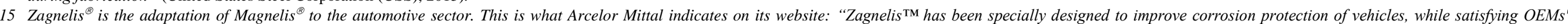

specifications regarding manufacturability" (Rich Clausius \& Arcelor Mittal, n.d.).

16 Grades according to EN 10244-2(CEN (European Committee for Standardization), 2009). In this way it has that a grade A corresponds to a thickness of 5 to 8 microns, while a grade B of 8 to 10 microns. 
Figure 19 compares the differences in terms of aluminium and magnesium content, while Figure 20 shows the sum of its contents, among the different suppliers. When it comes to corrosion, Figure 21 shows a summary of the different corrosion resistance hours, based on Neutral Salt Spray Test (NSST).

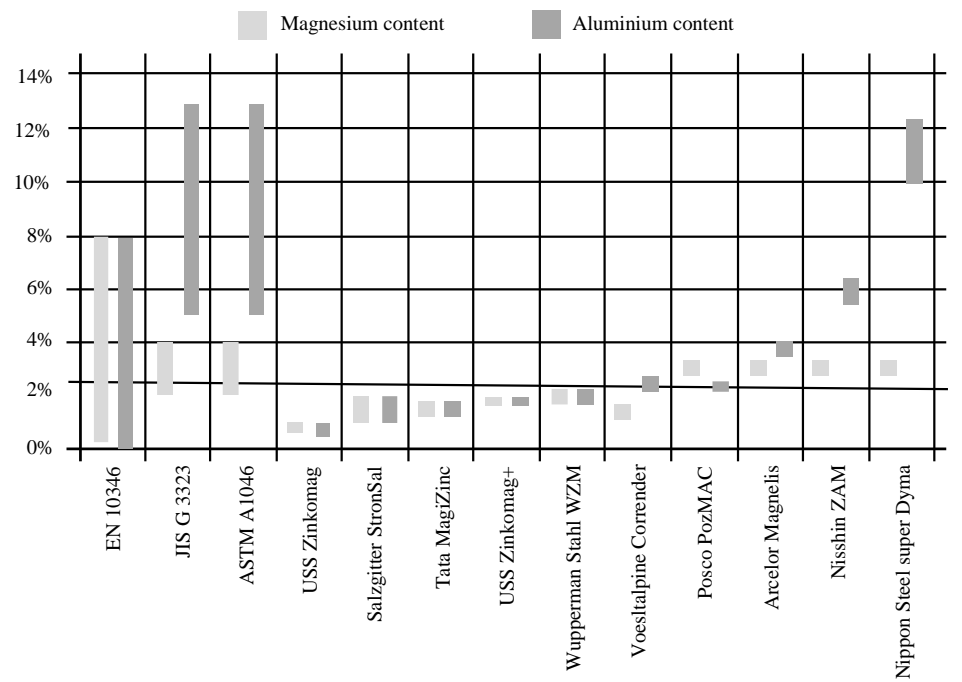

Figure 19: Content of aluminium and magnesium offered by the main ZM suppliers

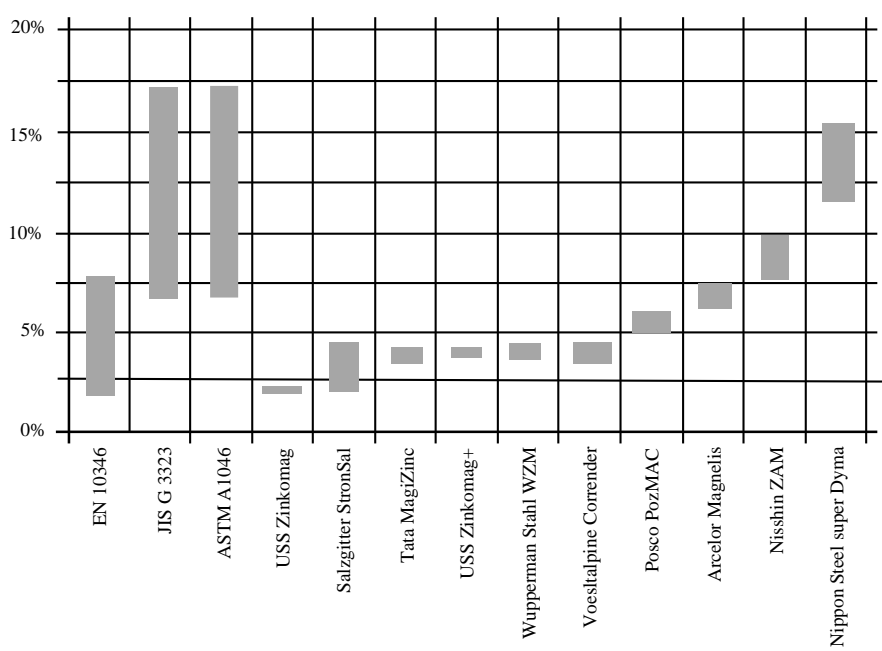

Figure 20: Sum of aluminium and magnesium content offered by the main ZM suppliers 


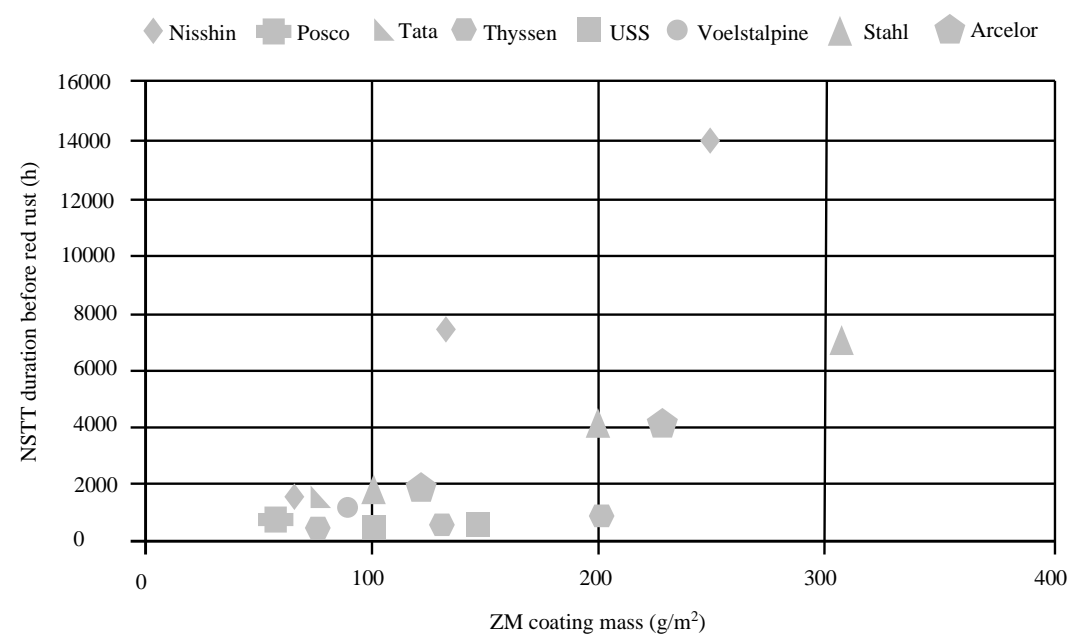

Figure 21: NSST duration before red rust. \% represents the sum of $\mathrm{Al}+\mathrm{Mg}$ content

As a conclusion to this section, it can be observed the high complexity of the global ZM offer, having different international standards, several commercial brands, many different coating compositions, different corrosion behaviours and very few direct equivalences between the available ZM products.

\subsection{Example of application: Cable trays systems}

\subsubsection{Brief Cable Tray systems introduction}

One of the fields in which the application of ZM alloys has been growing in recent years is metallic electrical wiring ducts, as is the case of cable trays. The reason why this specific application case has been chosen, is because it is especially interesting the large number of applications in multiple atmospheric environments and consequently the large number of types of coatings that manufacturers of this type of product offer, as it will be seen in the next subclause.

The International and European standards that rule this type of product are IEC 61537 (IEC, 2016) and EN 61537, both made by the same standardization working group (IEC and CENELEC). Table 17, extracted from this standard, shows the different type of coatings and their corrosion resistance classification.

According to these standards, a cable tray system is defined as an assembly of cable supports consisting of cable tray lengths and other system components. A cable tray length is defined as system component used for cable support consisting of a base with integrated side members or a base connected to side members, while a system component is defined as a part used within the system. System components are as follows: a) cable tray length or cable ladder length, b) cable tray fitting or cable ladder fitting, c) support device, d) mounting device, e) system accessory.

\subsubsection{Types of cable tray systems according to their metallic coating}

- Continuously hot-dip coated steel for cold forming, more popularly known in the industry as pregalvanized or Sendzimir sheet steel. It is a zinc coating with an oscillating thickness that depends on the quality required, turning around 10 and 35 microns. It is continuously galvanized, for a subsequent cold forming. For this last reason, the product is purchased on pre-galvanized coils and sheets, and after, it is conformed and shaped. This material is governed by the standard EN 10346 (CEN, 2015). Figure 22 , shows an example of metal tray with this type of material and coating. 


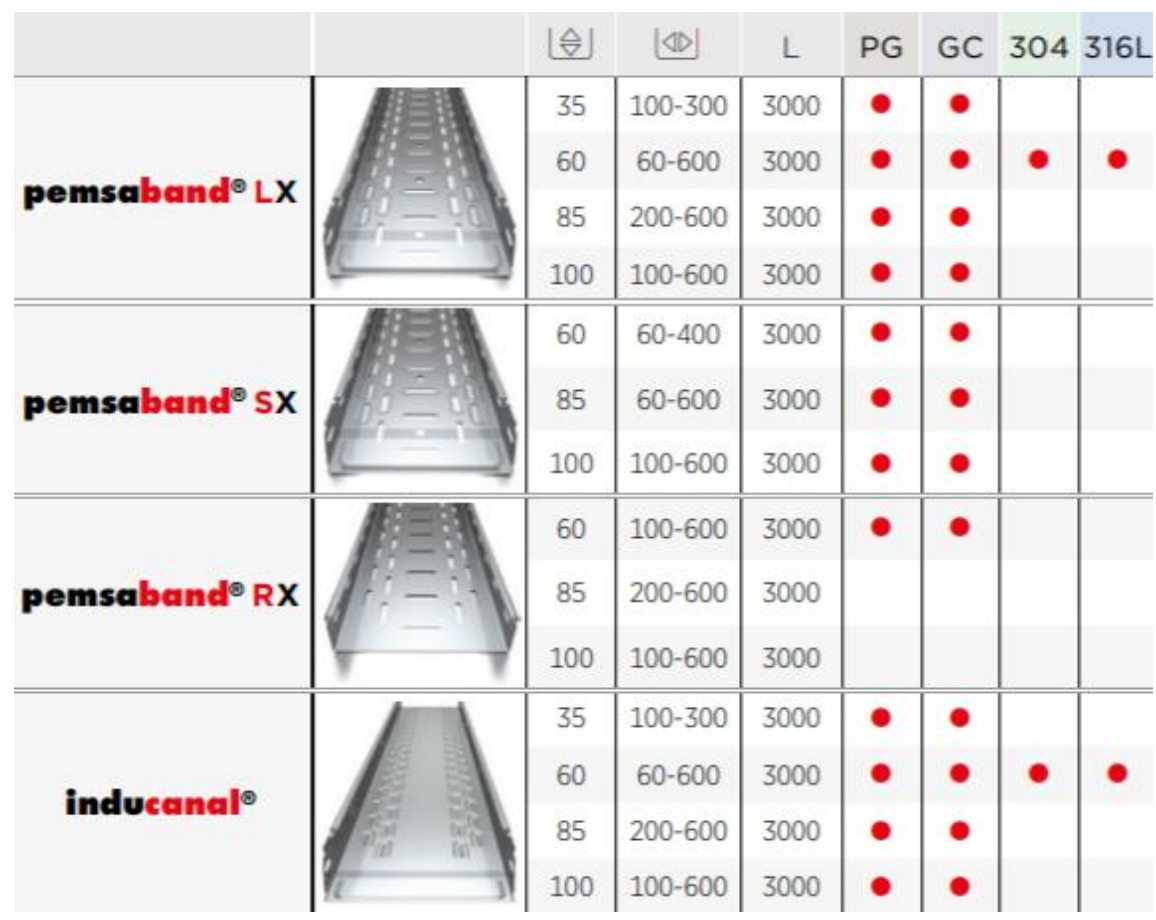

Figure 22: Example of pre-galvanized cable trays offer (Source: Pemsa Cable Management SAU - Spain. Public catalogue)

Table 15 shows as well, the different quality designations according to the coating mass expressed in $\mathrm{g} / \mathrm{m}^{2}$ and microns $(\mu \mathrm{m})$.

- Hot-Dip galvanized steel, it is a zinc coating as the previous one, with the difference that in this case the galvanizing process is not continuous. It is based on the immersion of the product in a molten zinc tank at about $400{ }^{\circ} \mathrm{C}$, piece by piece, so in this case, the tray is formed prior to the coating process. That's why this process is also known by post-galvanization. ISO 1461 (CEN, 2009) is the standard that governs the galvanizing process of this product. The thickness obtained for this type of coating varies depending on the thickness of the sheet, which usually varies from 1 to 2,5 millimetres on the market for this specific product; that's why, a normal average value in this type of product could be 50 microns. In any case, the thickness values are standardized in such standard as it can be seen in Table 20.

Table 20: Minimum coating thickness and mass on samples that are not centrifuged (ISO 1461)

\begin{tabular}{lcccc}
$\begin{array}{c}\text { Article and its } \\
\text { thickness }\end{array}$ & $\begin{array}{c}\text { Local coating } \\
\text { thickness (minimum) } \\
\mu \mathrm{m}\end{array}$ & $\begin{array}{c}\text { Local coating } \\
\text { mass (minimum) } \\
\mathrm{g} / \mathrm{m}^{2}\end{array}$ & $\begin{array}{c}\text { Mean coating } \\
\text { thickness (minimum) } \\
\mu \mathrm{m}\end{array}$ & $\begin{array}{c}\text { Mean coating } \\
\text { mass (minimum) } \\
\mathrm{g} / \mathrm{m}^{2}\end{array}$ \\
\hline Steel $>6 \mathrm{~mm}$ & 70 & 505 & 85 & 610 \\
Steel $>3$ to $\leq 6 \mathrm{~mm}$ & 55 & 395 & 70 & 505 \\
Steel $\geq 1,5$ to $\leq 3 \mathrm{~mm}$ & 45 & 325 & 55 & 395 \\
Steel $<1,5 \mathrm{~mm}$ & 35 & 250 & 45 & 325 \\
Castings $\geq 6 \mathrm{~mm}$ & 70 & 505 & 80 & 575 \\
Castings $<6 \mathrm{~mm}$ & 60 & 430 & 70 & 505 \\
\hline
\end{tabular}

NOTE This table is for general use: individual product standards may include different requirements including different categories of thickness. Local coating mass and mean coating mass requirements are set out in this table for reference in such cases of dispute.

- Stainless steel sheet. The above-mentioned sheet metal trays are also manufactured with this material, but with stainless steel sheet of AISI 304 or AISI 316 qualities. These qualities correspond to the American designation with which the qualities of stainless steels have traditionally been known. However, the classification according to IEC 61537 (IEC, 2016) is based in the standard EN 10088-1 (CEN, 2014), which establishes the European classifications for the different stainless steels, based on their chemical composition and reference data regarding some physical properties. In this way, AISI 304 quality stainless steel would correspond to an equivalent designation according to the European standard X5CrNi18-10 and numerical 1.4301. Table 17 extracted from IEC 61537, shows this specific classification designated by $9 \mathrm{~A}, 9 \mathrm{~B}, 9 \mathrm{C}$ and $9 \mathrm{D}$. 
With this, a high protection is offered to the entire conduction system against corrosion, but on the contrary, installations made with a stainless-steel sheet trays are excessively expensive, so this material is only used in very specific situations or in environments of high environmental aggression and that, in turn, the cables must be insulated.

- Electroplated. Electrogalvanized also known as zinc-plated or electroplating, is the process by which a layer of zinc is deposits by electrolysis on the steel through a bath of zinc salts. The basic principle of coating electrolytic processes involves the conversion of the anode metal into ions metallic that are distributed in the solution. These ions are deposited on the cathode (part to be coated) forming a metallic layer on its surface. In this coating process the layer deposited forms metallic crystals. The electrolytic coating of the pieces is produced almost exclusively by immersion in a bath. For this, the pieces are immersed into the tanks where the electrolyte is, the current is applied as a cathode, they are coated and finally they are dried. In this case, the coating process is based on the standard EN ISO 2081 (CEN, 2018), obtaining a thickness of around 8-10 microns. Depending on the layer of passivation, the corrosion protection can be higher or lower, as well as its aesthetic appearance. For instance, in the market it can be found white electroplated, yellow (or bycromated) electroplated, etc. Figure 23 shows an example of white and electroplated finish, applied to a mesh cable tray:

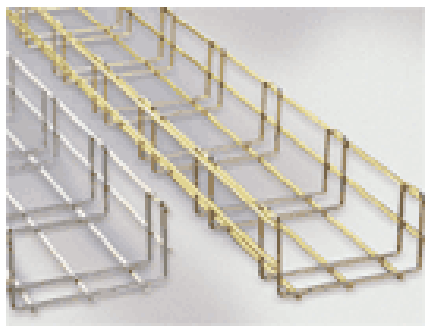

Figure 23: Example of white and yellow electroplated finish in mesh cable trays (Source: Schneider Electric, public catalogue)

- Aluminium. The use of this material in trays is generally less than the previously mentioned, largely due to its price. An adequate summary of the use and characteristics of this type of material is stated in the Manual of pipes for cable tray systems of the company GEDISA (Gedisa, 2008), according to which the aluminium cable tray due to its excellent resistance to corrosion in many chemical environments, it has been used in the petrochemical and oil industry and above all, in coastal areas. Typically, aluminium cable trays can be used indefinitely, with little or no degradation over time, making them ideal for many chemical and marine environments. Cable trays made of extruded aluminium are very often used due to their high strength-to-weight ratio, high resistance to certain corrosive environments, and ease of installation. They also offer the advantages of having a very light weight (approximately 50\% of a steel tray) and they are maintenance-free, because the aluminium cable trays are non-magnetic, avoiding electrical losses to a minimum. The extraordinary resistance to corrosion, including the wear action of natural agents, make it one of the most suitable materials for installations such as those referred to with a very high level of guarantee, despite its high cost.

- Aluminium alloys. They are the coatings to which the scope of this standard refers. Over the past few years, research has been conducted into how aluminium and magnesium additions can significantly improve the corrosion resistance of traditional, exclusively zinc-based coatings. Several manufacturers have started to use this type of coatings as an alternative, and sometimes a replacement of their zincbased coatings, as it will be seen in the next clause.

\subsubsection{Cable trays system manufacturers using $\mathrm{ZM}$ alloys}

Table 21 shows a summary of the main electrical cable trays system manufacturers using ZM alloys. This type of application will be the one that will be used later in the Case study (clause 5). 
Table 21: Examples of cable trays system manufacturers using ZM and ZA alloys (standard or wire cable trays)

\begin{tabular}{|c|c|c|c|c|}
\hline Manufacturer & Manufacturer trademark & $\begin{array}{l}\text { Raw material } \\
\text { manufacturer }\end{array}$ & $\begin{array}{l}\text { Raw material } \\
\text { manufacturer } \\
\text { trademark }\end{array}$ & $\begin{array}{l}\text { Manufacturer declared } \\
\text { corrosion class (IEC 61537) }\end{array}$ \\
\hline Schneider Electric ${ }^{\circledR}$ & $\mathrm{Zn}+{ }^{1}$ & Not declared & Not declared & 8 \\
\hline Obo Betterman ${ }^{\circledR}$ & Double Dip ${ }^{2}$ & Thyssen Krupp ${ }^{\circledR}$ & Not declared & $\geq 8$ \\
\hline Gewiss ${ }^{\circledR}$ group & High Protection $\mathrm{HP}^{3}$ & Arcelor Mittal $^{\circledR}$ & Not declared & $\geq 8(1000 \mathrm{~h})$ \\
\hline Legrand $^{\circledR}$ & Cablofil Zinc-Aluminium ${ }^{4}$ & Not declared & Not declared & C3, C4 (ISO 9223) \\
\hline Vergokan $^{\circledR}$ & Zinc Magnesium ${ }^{5}$ & Not declared & Not declared & $>1000 \mathrm{~h}$ \\
\hline Vergokan ${ }^{\circledR}$ & Zinc Aluminium 5 & Not declared & Not declared & $>1000 \mathrm{~h}$ \\
\hline Zamet $^{\circledR 6} 6$ & - & Arcelor Mittal $^{\circledR}$ & Magnelis ${ }^{\circledR}$ & - \\
\hline Aiscan $^{\circledR}$ & Magnelis ${ }^{7}$ & Arcelor Mittal $^{\circledR}$ & Magnelis ${ }^{\circledR}$ & 8 \\
\hline
\end{tabular}

${ }^{1}$ Schneider Electric ${ }^{\circledR}$ (Schneider Electric, 2011, 2012)

${ }^{2}$ Obo Betterman ${ }^{\circledR}$ (Obo Betterman, 2012)

${ }^{3}$ Gewiss ${ }^{\circledR}$ group (Gewiss, 2016; Mavil (Gewiss group), 2015)

${ }^{4}$ Legrand $^{\circledR}$ Cable Management (Cablofil (Legrand), 2016; Legrand, 2016, 2019b, 2019a, 2019c)

${ }^{5}$ Vergokan $^{\circledR}$ (Vergokan, 2019c, 2019a, 2019b)

${ }^{6}$ Zamet $^{\circledR}$ (Zamet, 2020)

${ }^{7}$ Aiscan $^{\circledR}$ (Aiscan, 2019) 


\subsection{Accelerated corrosion tests on $\mathbf{Z M}$}

\subsubsection{Introduction}

There are currently numerous accelerated corrosion tests whose main objective is to demonstrate the behaviour of the analysed coatings in a comparative way, in the absence of sufficient field tests to demonstrate the performance of the new ZM alloys compared to traditional $\mathrm{Zn}$ coatings. Even though nowadays, there are many existing field tests or being currently carried out, as will be seen in the following sections, these are few and of a very limited duration.

Although the objective of this thesis is to focus on field tests to analyse the real behaviour of the referred coatings, it has been considered important to carry out a search for accelerated tests, as a sample of the contribution that in this sense exists in the current state of the technique and in order to see to what extent, these results correlate with the actual results.

\subsubsection{Accelerated tests description and main conclusions}

\section{$\underline{\text { Accelerated Test \#1 }}$}

- Type of test:

- Duration:

- Tested materials:

- Test year:

- Related references:

- Results:
Neutral salt spray test (ISO (International Organization for Standardization), 2012b) $1000 \mathrm{~h}$

ZM alloy: Magnelis ${ }^{\circledR} 90 \mathrm{~g} / \mathrm{m}^{2}$

ZM alloy: Magnelis ${ }^{\circledR} 120 \mathrm{~g} / \mathrm{m}^{2}$

$\mathrm{ZM}$ alloy: Magnelis ${ }^{\circledR} 250 \mathrm{~g} / \mathrm{m}^{2}$

ZM alloy: Magnelis ${ }^{\circledR} 310 \mathrm{~g} / \mathrm{m}^{2}$

ZA alloy 1: $185 \mathrm{~g} / \mathrm{m}^{2}$

ZA alloy $2: 185 \mathrm{~g} / \mathrm{m}^{2}$

$\mathrm{Z} 1: 275 \mathrm{~g} / \mathrm{m}^{2}$

$\mathrm{Z} 2: 275 \mathrm{~g} / \mathrm{m}^{2}$

2013

(IPU (Ingenieursozietät Peil Ummenhofer), 2013)

Table 22: Accelerated test \#1 summary and corrosion rate

\begin{tabular}{ccc} 
Process \& Material coating & Designation & Corrosion rate $(\mu \mathrm{m})$ \\
\hline Zinc-Continuous galvanized & $275 \mathrm{~g} / \mathrm{m}^{2}$ & $132 \mathrm{~g} / \mathrm{m}^{2}$ \\
Zinc- Continuous galvanized & $275 \mathrm{~g} / \mathrm{m}^{2}$ & $147 \mathrm{~g} / \mathrm{m}^{2}$ \\
ZM alloy- Continuous galvanized & $90 \mathrm{~g} / \mathrm{m}^{2}$ & $3,21 \mathrm{~g} / \mathrm{m}^{2}$ \\
ZM alloy-Continuous galvanized & $90 \mathrm{~g} / \mathrm{m}^{2}$ & $4,03 \mathrm{~g} / \mathrm{m}^{2}$ \\
ZM alloy-Continuous galvanized & $120 \mathrm{~g} / \mathrm{m}^{2}$ & $7,2 \mathrm{~g} / \mathrm{m}^{2}$ \\
ZM alloy-Continuous galvanized & $120 \mathrm{~g} / \mathrm{m}^{2}$ & $3,76 \mathrm{~g} / \mathrm{m}^{2}$ \\
ZM alloy-Continuous galvanized & $250 \mathrm{~g} / \mathrm{m}^{2}$ & $4,84 \mathrm{~g} / \mathrm{m}^{2}$ \\
ZM alloy-Continuous galvanized & $250 \mathrm{~g} / \mathrm{m}^{2}$ & $4,29 \mathrm{~g} / \mathrm{m}^{2}$ \\
ZM alloy-Continuous galvanized & $310 \mathrm{~g} / \mathrm{m}^{2}$ & $3,7 \mathrm{~g} / \mathrm{m}^{2}$ \\
ZM alloy-Continuous galvanized & $310 \mathrm{~g} / \mathrm{m}^{2}$ & $7,37 \mathrm{~g} / \mathrm{m}^{2}$ \\
ZM alloy-Continuous galvanized & $310 \mathrm{~g} / \mathrm{m}^{2}$ & $10,3 \mathrm{~g} / \mathrm{m}^{2}$ \\
ZA alloy-Continuous galvanized & $185 \mathrm{~g} / \mathrm{m}^{2}$ & $129 \mathrm{~g} / \mathrm{m}^{2}$ \\
ZA alloy-Continuous galvanized & $185 \mathrm{~g} / \mathrm{m}^{2}$ & $13,8 \mathrm{~g} / \mathrm{m}^{2}$ \\
\hline
\end{tabular}

- Summary:

Arcelor Mittal Global R\&D, in a partnership with Peil Ummenhofer and Partner (IPU) ordered an expert's report to test, compare and assess the corrosion resistance of the following metallic coatings for the classification into corrosion protection classes, according to DIN 55928-8:

- Zinc-Aluminium-Magnesium (Magnelis ${ }^{\circledR}$ ) with a coating mass of 90, 120, 250 and $310 \mathrm{~g} / \mathrm{m}^{2}$

- Aluminium zinc (AZ185) with a coating mass of $185 \mathrm{~g} / \mathrm{m}^{2}$

- $\quad$ Zinc (Z275) with a coating mass of $275 \mathrm{~g} / \mathrm{m}^{2}$

Three type of tests were performed:

i. Resistance against neutral salt spray test, not defining which standard was used for testing, whereas evaluation was done according to DIN EN ISO 10289 (ISO (International Organization for Standardization), 
1999), for resistance against protection ( $\mathrm{Rp})$ and appearance (Ra), from 200 to $1000 \mathrm{~h}$ each 200 hours. The test done has shown that attack to coating ZM is considerably slower, compared to coatings Z275 and AZ185; Z275 already showed red rust after a duration period of 600 hours, whereas samples with Magnelis ${ }^{\circledR}$ did not show any, even after 1000 hours of exposure. The evaluation of the mass loss confirms the results of the evaluation of the surface. The mass loss of the metallic coating AZ185 is several times larger; with a coating mass of $250 \mathrm{~g} / \mathrm{m}^{2}$, Magnelis ${ }^{\circledR}$ provides a theoretical protection period of 1,81-times higher than the metallic coating AZ185. These results clearly show that Magnelis ${ }^{\circledR}$ provides a considerably higher protection against the salt spray tests compared to Z275 or AZ185.

ii. Resistance against condensation of water which evaluation was done according to DIN EN ISO 10289, for resistance against protection (Rp) and appearance ( $\mathrm{Ra})$, from 200 to $1000 \mathrm{~h}$ each 200 hours. The tested metallic coatings had a similar behaviour with exposure in condensation of water, however, the metallic coating AZ185 were detected on the surface dark changes in colour. These initial damages can rapidly proceed under further exposure and cause red rust on the base material. The results of the investigation indicate that Magnelis ${ }^{\circledR}$ provides higher resistance against exposure in condensation of water compared to AZ185.

iii. Humid, sulphur dioxide atmosphere, with an exposure of 30 cycles with 0,2 1 sulphur dioxide that blistering must not exceed quantity 2 or dimension 3 . These evaluation criteria are inapplicable to metallic coatings without organic coating. The evaluation of the resistance to humid, sulphur dioxide occurred after an exposure of 1, 2, 5, 7, 10, 20 and 30 cycles according to DIN EN ISO 10289. None of the tested samples indicated corrosion or damage on the base material. All of them were evaluated with a protection degree of 10 .

After one cycle already, samples with Magnelis ${ }^{\circledR}$ showed a change in colour of the metallic Coating. After two cycles, samples with Z275 and AZ185 showed a change in colour of the Metallic coatings, too. The change in colour of all samples increased with the period of duration. The tested metallic coatings show a similar behaviour regarding the change in colour.

After 20 cycles, two of the tested samples and after 30 cycles, all samples with the metallic coating AZ185 showed pitting corrosion on the surface; these damages can rapidly proceed under further loads and cause red rust of the base material. This shows that the resistance of Magnelis ${ }^{\circledR}$ against humid, sulphur dioxide atmosphere is higher compared to AZ185.

\section{$\underline{\text { Accelerated Test \#2 }}$}

- Type of test:

- Duration:

- Tested materials:

- Test year:

- Related references:

- Results:

Neutral salt spray test (ISO (International Organization for Standardization), 2012b)

100 h, 200 h, $400 \mathrm{~h}$

ZM alloy: $\mathrm{ZnMg} 3 \% \mathrm{Al} 3,7 \%$

ZA alloy: $\mathrm{Zn} 5 \% \mathrm{Al}$

Z: $20 \mu \mathrm{m}(\mathrm{CEN}, 2009)$

2015

(Salgueiro Azevedo et al., 2015b, 2015a)

Table 23: Accelerated test \#2 summary and corrosion rate $(\mu \mathrm{m})$

\begin{tabular}{lccc}
\multicolumn{1}{c}{ Electrolyte / Duration } & Z finish & ZM finish & ZA finish \\
\hline Neutral Salt Spray Test - 0,1\% NaCl - 100 h & 5,4 & 0,5 & 0,6 \\
Neutral Salt Spray Test - 1\% NaCl - 100 h & 6,9 & 0,3 & 0,5 \\
Neutral Salt Spray Test - 5\% NaCl - 100 h & 11,2 & 0,9 & - \\
Neutral Salt Spray Test - 0,4\% NaCl - 400 h & 14 & 2,3 & 4 \\
Neutral Salt Spray Test VDA -1\% NaCl - 5 cycles & 5,8 & 0,6 & 2 \\
Neutral Salt Spray Test - 1\% Na2SO $-100 \mathrm{~h}$ & 3,2 & 0,3 & - \\
Neutral Salt Spray Test - 0,1\% Rainwater - 100 h & 3,6 & 1,2 & - \\
Neutral Salt Spray Test - 1\% Rainwater - 200 h & 8,5 & 3,1 & 4,5 \\
Neutral Salt Spray Test VDA - 0,1\% Rainwater - 10 cycles & 7,4 & 1,9 & 3,4 \\
Neutral Salt Spray Test modified- 1\% Rainwater 200 h & 4,7 & 0,7 & - \\
\hline
\end{tabular}

- Summary:

The main aim of this paper was to highlight the effect of the electrolyte composition in the corrosion process. Main highlights:

- It is demonstrated the better performance of ZM alloys in high chloride content environments, but its performance is lower in real life, which is demonstrated with the tests done in this work using distilled rainwater. 
- The corrosion products are key for the corrosion process and those are quite dependant on the electrolyte, as well as on the alloy composition. This has been demonstrated after the analysis over the tests run.

\section{$\underline{\text { Accelerated Test \#3 }}$}

- Type of test:

- Duration:

- Tested materials:

- Test year:

- Related references:

- Results:

Cyclic test according to Volvo ${ }^{\circledR}$ STD 423-0014 (V. Group, 2009)

3 weeks, 6 weeks, 18 weeks

$\mathrm{ZM}$ alloy: $\mathrm{ZnMg} 1 \% \mathrm{~A} 11 \%$

$\mathrm{ZA}$ alloy: $\mathrm{Zn} 5 \% \mathrm{Al}$

Z: $7 \mu \mathrm{m}$ HDG (CEN, 2009)

Z: $7 \mu \mathrm{m}$ electroplated (CEN, 2018)

2013

(Autocoat - European Comission, 2013; LeBozec et al., 2013)

Table 24: Accelerated test \#3 summary and corrosion rate $(\mu \mathrm{m})$

\begin{tabular}{lcccc} 
Test duration & $\begin{array}{c}\text { Z finish } \\
\text { (HDG) }\end{array}$ & $\begin{array}{c}\text { Z finish } \\
\text { (Electroplated) }\end{array}$ & ZM alloy & ZA finish \\
\hline 3 weeks & 10 & 15 & 0 & 0 \\
6 weeks & 40 & 30 & 0 & 10 \\
18 weeks & 310 & 410 & 190 & 230 \\
\hline
\end{tabular}

- Summary:

French corrosion institute performed a study to promote the novel ZnAlMg coating in the automotive industry through corrosion mechanism, relation between coating composition and microstructure in corrosion performance, surface oxide on paint adhesion in order to optimize or eliminate phosphating process, evaluation of corrosion stability of ZnAlMg using accelerated corrosion test accepted by automotive industries (VDA 621-415, N-VDA (VDA233-102) and Volvo STD 423-0014.

According to the authors, these were the key conclusions of the work:

- The corrosion performance of ZMA coatings is depending on testing conditions \& configurations:

$o$ the advantageous effect of ZMA coatings is more pronounced in open situations than in confined ones.

o higher relative corrosion performances are observed in environments involving high chloride load compared to conventional zinc coatings.

o the beneficial effect of ZMA coatings less obvious in tests with low salt load as well as in field.

o ZMA are more affected than GI in low $\mathrm{CO} 2$ conditions

- The corrosion performance of ZMA vs HDG may be linked to the microstructure and a better stability of surface $\mathrm{pH}$ at cathodes.

- Weldability \& Adhesive bonding: comparable properties as HDG • Formability: presence of cracks without detrimental on corrosion

- Phosphatation: good robustness to process variation.

\section{Accelerated Test \#4}

- Type of test:

- Duration:

- Tested materials:

- Test year:

- Related references:
Cyclic test according to Volvo ${ }^{\circledR}$ STD 1027, 3371 (Volvo, 2010b, 2010a)

10 cycles of $24 \mathrm{~h}$

ZM120 alloy: $\mathrm{ZnMg} 3 \% \mathrm{Al} 3,7 \%$

Z: HDG - Not material declared (CEN, 2009)

$\mathrm{Z}: 275 \mathrm{~g} / \mathrm{m}^{2}$

2015

(Arcelor Mittal, 2015; Galvazinc \& Cetim, 2014) 
- Results:

Table 25: Accelerated test \#4 summary and corrosion rate $(\mu \mathrm{m})$

\begin{tabular}{cccc} 
Test duration & $\begin{array}{c}\mathrm{Z} \text { finish } \\
\text { (HDG) }\end{array}$ & $\begin{array}{c}\text { Z finish } \\
\text { (pre-galvanized) }\end{array}$ & ZM alloy \\
\hline 10 cycles of $24 \mathrm{~h}$ & 10,2 & 8,16 & 11,52
\end{tabular}

- Summary:

Cyclic test according to Volvo STD 1027 with a higher acid content in a SO2 atmosphere. Main conclusion was that losses in $\mu \mathrm{m}$ of metallic protection are superior for Magnelis ${ }^{\circledR}$ than pure zinc.

ZM coatings are very well performing in harsh atmospheres with high humidity and high chloride load, but this good behaviour is less relevant in $\mathrm{SO}_{2}$ / acid atmosphere or with low humidity. On the other hand, is true that more and more, in many countries around the world, mostly in advanced economies, the level of emissions of $\mathrm{SO} 2$ has been drastically reduced, acquiring a more relevant importance NOx emissions.

\section{$\underline{\text { Accelerated Test \#5 }}$}

- Type of test:

Cyclic test according to N-VDA 233-102 ((VDA), 2013)

- Duration:

6, 12 weeks

- Tested materials:

ZM alloy: $\mathrm{ZnMg} 1 \% \mathrm{Al} 1 \%$

ZM alloy: $\mathrm{ZnMg} 1,5 \% \mathrm{~A} 11,5 \%$

ZM alloy: $\mathrm{ZnMg} 2 \% \mathrm{~A} 12 \%$

Z: HDG - $7 \mu \mathrm{m}$ (CEN, 2009)

- Test year:

$\mathrm{Z}: 7 \mu \mathrm{m}$ electroplated (CEN, 2018)

- Related references: $\quad$ (LeBozec et al., 2013)

- Results:

Table 26: Accelerated test \#5 summary and corrosion rate $(\mu \mathrm{m})$

\begin{tabular}{lcccccc} 
Test duration & $\begin{array}{c}\mathrm{Z} \\
(\mathrm{HDG})\end{array}$ & $\begin{array}{c}\mathrm{Z} \\
(\mathrm{EZ})\end{array}$ & $\begin{array}{c}\text { ZM alloy } \\
\text { (ZnMg1\%Al1\%) }\end{array}$ & $\begin{array}{c}\text { ZM alloy } \\
(\text { ZnMg1,5\%Al1,5\%) }\end{array}$ & $\begin{array}{c}\text { ZM alloy } \\
(\mathrm{ZnMg} 2 \% \text { A12\%) }\end{array}$ & ZA \\
\hline 6 weeks & 85 & 95 & 25 & 0 & 0 & 55 \\
12 weeks & 310 & 315 & 260 & 170 & 195 & 255 \\
\hline
\end{tabular}

\section{- Summary:}

The purpose of this test is to provide an accelerated test procedure for the assessment of the corrosion behaviour of components and of the corrosion protection provided by coating systems. The test method is based on real corrosive conditions and delivers differentiated results for a large number of uses in automotive applications.

Test specimens are placed in an enclosed chamber and positioned at an angle of $65^{\circ}$ to $75^{\circ}$ to the horizontal with the side to be tested uppermost. The salt spray phase is performed with a $1 \%$ solution of sodium chloride, $(\mathrm{pH} 6.5$ to 7.1) and falls out onto the specimens at a rate of 2.0 to $4.0 \mathrm{ml} / 80 \mathrm{~cm}^{2} / \mathrm{hour}$.

A full test cycle lasts 7 days and consists of: Cycles A, B \& C are multi step cycles consisting of varying degrees of temperature from $-15^{\circ} \mathrm{C}$ to $+50^{\circ} \mathrm{C}$ and humidity values of between $50 \%$ and $95 \%$.

\section{$\underline{\text { Accelerated Test \#6 }}$}

- Type of test:

- Duration:

- Tested materials:

- Test year:

- Related references:
Cyclic test according to VDA 621-415 ((VDA), n.d.)

6, 12 weeks

ZM alloy: $\mathrm{ZnMg} 1 \% \mathrm{Al1} \%$

ZM alloy: $\mathrm{ZnMg} 1,5 \% \mathrm{Al1}, 5 \%$

ZM alloy: $\mathrm{ZnMg} 2 \% \mathrm{Al} 2 \%$

$\mathrm{Z}: \mathrm{HDG}-7 \mu \mathrm{m}$ (CEN, 2009)

Z: $7 \mu \mathrm{m}$ electroplated (CEN, 2018)

2013

(LeBozec et al., 2013) 
- Results:

Table 27: Accelerated test \#6 summary and corrosion rate $(\mu \mathrm{m})$

\begin{tabular}{lcccccc} 
Test duration & $\begin{array}{c}\mathrm{Z} \\
\text { (HDG) }\end{array}$ & $\begin{array}{c}\mathrm{Z} \\
(\mathrm{EZ})\end{array}$ & $\begin{array}{c}\text { ZM alloy } \\
(\mathrm{ZnMg} 1 \% \text { Al1\% })\end{array}$ & $\begin{array}{c}\text { ZM alloy } \\
(\mathrm{ZnMg} 1,5 \% \text { Al1,5\%) }\end{array}$ & $\begin{array}{c}\text { ZM alloy } \\
(\mathrm{ZnMg} 2 \% \mathrm{~A} 12 \%)\end{array}$ & ZA \\
\hline 6 weeks & 40 & 60 & 0 & 0 & 0 & 5 \\
12 weeks & 220 & 300 & 5 & 170 & 0 & 50 \\
\hline
\end{tabular}

- Summary:

- $\quad$ Largest improvement for $\mathrm{ZM}(\mathrm{Zn}-1 \% \mathrm{Al}-1 \% \mathrm{Mg}$ and $\mathrm{Zn}-2 \% \mathrm{Al}-2 \% \mathrm{Mg})$ as compared to hot dip and electroplated zinc coatings was obtained on openly exposed surfaces in the cyclic test with the highest salt load (VDA 621-415).

- ZM coatings provide significant improvement in comparison to traditional coatings, as hot dip zinc, in tests involving significant salt load (cyclic tests with significant salt supply or neutral salt spray testing) especially on openly exposed surfaces while less obvious beneficial effects are seen in cyclic tests with lower salt load

\subsection{Field corrosion tests on $\mathrm{Z}$ and $\mathrm{ZM}$ alloys coatings}

\subsubsection{Introduction}

The investigation on the background carried out for the present thesis, showed the so important limitations existing at present, to be able to model the behaviour of the corrosion of this type of alloys, considering, as it will be seen below, that there is a maximum period of field corrosion tests of 6 years and not for all corrosivity categories. Actually, these 6 years period field tests were recently published (2019). Even though that, some conclusions can already begin to be drawn that can help to solve the problem addressed in this thesis.

A total of 10 field tests have been selected. They have been carried out in different locations around the world, for different durations of exposure and for different type of materials. Most of them have included also traditional zinc coatings samples, to be able to compare both type of finishes.

\subsubsection{Field tests description and main conclusions}

\section{Field Test \#1}

- Locations:

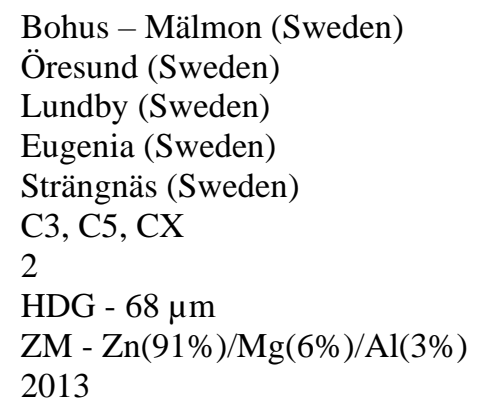

- Related references:

- "Corrosion performance - Real performance evaluations in infrastructure applications" (Nordic Galvanizers, n.d.).

- "Alternative materials for Cable Tray systems" (Swerea Kimab, 2014).

- Summary:

Nordic Galvanizers (Nordic Galvanizers, n.d.), performed a field test in Sweden in cooperation with Swerea KIMAB (Swerea Kimab, 2014) which aim was to raise the knowledge about how different materials cope with the environment in tunnels. The goal was to create a guideline for appropriate material selection, both for new installations and for maintenance of existing tunnels. Previous studies have shown that many motorway tunnels seem to be very aggressive to zinc, with an annual corrosion rate of about $7 \mu \mathrm{m} /$ year (corrosion class C5).A comparison has been carried-out for different materials: black steel, hot-dip galvanized (coating thickness $68 \mu \mathrm{m}$ ), $\mathrm{ZM}$ materials (Zn6Al3Mg), pre-galvanized coating $(20 \mu \mathrm{m})$, stainless steel and aluminium coupons in train and motorways tunnels, exposed to splash from car traffic and reference site (marine) environments during 2 years. Table 28 shows a sum-up of the test as well as the corrosion rates results measured. 
Table 28: Field test \#1 summary and corrosion rate

\begin{tabular}{cllrrrrr}
\multirow{2}{*}{ Test code } & \multirow{2}{*}{ Location } & Environment & Corrosivity & \multicolumn{4}{c}{ Corrosion rate $(\mu \mathrm{m})$} \\
\cline { 5 - 7 } & & & Category & \multicolumn{3}{c}{ HDG } & \multicolumn{2}{c}{ ZM } \\
\cline { 5 - 7 } & & & Year 1 & Year 2 & Year 1 & Year 2 \\
\hline 1.1 & Bohus - Malmön & Marine & & 1,6 & 2,8 & 0,7 & 1,3 \\
1.2 & Öresund & Traffic tunnel & CX & 9,9 & 15,6 & 6,5 & 12,3 \\
1.3 & Lundby & Traffic tunnel & CX & 10,2 & 17 & 7,4 & 13,3 \\
1.4 & Eugenia & Traffic tunnel & C5 & 6,6 & 11 & 4,8 & 9,2 \\
1.5 & Öresund & Train tunnel & C3 & 1,6 & 3 & 1 & 1,8 \\
1.6 & Strängnäs & Train tunnel & C3 & 1 & 1,6 & 0,2 & 0,7 \\
\hline
\end{tabular}

- Conclusions:

Motorway tunnels are much more corrosive than railway tunnels because of higher humidity, pollutants (splashes from cars) and chlorides. Also, the presence of nitrogen and sulphur compounds can increase the corrosion rate in motorway tunnels compared to railway tunnels. The corrosion rate in year two is consistently lower than year one, because the corrosion products protect the underlying surface.

In marine reference sites, for the first and the second year of exposure, ZM alloys have half the corrosion rate compared to HDG. In traffic tunnels reference sites, ZM alloys showed close to $30 \%$ less corrosion rate than HDG for the first-year exposure and slightly lower results for the second year.

Finally, the report concludes that it must be analysed the corrosion rate of $\mathrm{ZM}$ in front of traditional $\mathrm{Z}$ coatings, considering the difference in thickness that both coatings can reach.

\section{Field Test \#2}

- Locations: Brest (France)

Langonnet (France)

- Corrosivity categories: C3, C4

- Exposure years: 1

- Tested materials: $\quad$ PG $-275 \mathrm{~g} / \mathrm{m}^{2}$

$\mathrm{ZM}-\mathrm{Zn} 3,5 \% \mathrm{Al} 3 \% \mathrm{Mg}$ (test 2.1)

- Test Year:

$\mathrm{ZM}-\mathrm{Zn}(1-3) \% \mathrm{Al}(1-3) \% \mathrm{Mg}$ (tests 2.2, 2.3)

- Related references:

2011

- "ZnAlMg: an innovative metallic coating that offers protection in the harshest environments" (SchoullerGuinnet, Allély, \& Volovitch, 2011).

- "Corrosion protection and corrosion mechanisms of continuous galvanized steel sheet with focus on new coating alloys”(D. Thierry, Prosek, Bozec, \& E. Diller, 2011).

- Summary:

A field test in a marine environment site in Brest, France (steel corrosivity category C5 and zinc corrosivity category C3) was carried-out by Schouller-Guinet et al. ZM alloys and PG zinc (open panels) samples were tested. It was found a first-year corrosion rate of $\mathrm{ZM}(\mathrm{Zn} 3,5 \% \mathrm{Al} 3 \% \mathrm{Mg})$ of $0,45 \mu \mathrm{m}$ and $1,2 \mu \mathrm{m}$ for pre-galvanized finish. Same experiment was arranged in a rural atmosphere (C3 corrosivity category) in Langonnet, France, with a clear difference in corrosion rate from both coatings, in a similar proportion than for the other 2 environments.

Table 29 shows a sum-up of the test as well as the corrosion rates obtained.

Table 29: Field test \#2 summary and corrosion rate

\begin{tabular}{|c|c|c|c|c|c|}
\hline \multirow{3}{*}{ Test code } & \multirow{3}{*}{ Location } & \multirow{3}{*}{ Environment } & \multirow{3}{*}{$\begin{array}{l}\text { Corrosivity } \\
\text { Category }\end{array}$} & \multicolumn{2}{|c|}{ Corrosion rate $(\mu \mathrm{m})$} \\
\hline & & & & PG & $\mathrm{ZM}$ \\
\hline & & & & Year 1 & Year 1 \\
\hline 2.1 & Brest (France) & Marine & $\mathrm{C} 3$ & 1,2 & 0,45 \\
\hline 2.2 & Brest (France) & Marine & $\mathrm{C} 4$ & 2,2 & 1 \\
\hline 2.3 & Langonnet (France) & Rural & $\mathrm{C} 3$ & 1,9 & 0,9 \\
\hline
\end{tabular}

- Conclusions:

$\mathrm{ZM}$ coatings performed better in both environments than pure zinc. The performance factor based in corrosion ratio $(\mathrm{PG} / \mathrm{ZM})$ was in all cases around 2 , including the rural environment. 


\section{$\underline{\text { Field Test \#3 }}$}

$\begin{array}{ll}\text { - Locations: } & \text { Brest (France) } \\ & \begin{array}{l}\text { Dortmund (Germany) } \\ \text { Linz (Austria) }\end{array} \\ \text { - Corrosivity categories: } & \text { C2, C3, C4, C5 } \\ \text { - Exposure years: } & 2 \\ \text { - Tested materials: } & \text { PG } \quad 7 \mu \mathrm{m} \\ & \mathrm{EZ} \quad 7 \mu \mathrm{m} \\ & \mathrm{ZM} 1 \quad \mathrm{Zn} 1 \% \mathrm{Al1} \% \mathrm{Mg} \\ & \mathrm{ZM} 1,5 \quad \mathrm{Zn} 1,5 \% \mathrm{Al1,5 \% \textrm {Mg }} \\ & \mathrm{ZM} 2 \quad \mathrm{Zn} 2 \% \mathrm{~A} 12 \% \mathrm{Mg} \\ \text { - Test Year: } & 2013\end{array}$

- Related references:

- "Corrosion performance of $\mathrm{Zn}-\mathrm{Mg}-\mathrm{Al}$ coated steel in accelerated corrosion tests used in the automotive industry and field exposures" (LeBozec et al., 2012, 2013).

- "Advanced zinc-based hot-dip coatings for the automotive application. European Commission report" (Autocoat - European Comission, 2013).

- "Advanced zinc-based hot dip coatings for the automotive application. Autocoat" (Autocoat, 2013)

- Summary:

French corrosion institute performed a study to promote ZM coatings in the automotive industry, from corrosion point of view. Several tests were arranged: relation between coating composition and microstructure in corrosion performance, surface oxide on paint adhesion in order to optimize or eliminate phosphation process, etc.

It was also arranged, an evaluation of corrosion stability of ZM coatings using accelerated corrosion tests accepted by automotive industries (VDA 621-415, N-VDA [VDA233-102] and Volvo ${ }^{\circledR}$ STD 423-0014), the mechanical properties of formability and joining and field exposure tests: Brest (Marine), Dortmund (industrial/Urban) and Linz (Continental). Different suppliers were used: Voestalpine ${ }^{\circledR}$, Ruuki $^{\circledR}$, and TKSE ${ }^{\circledR}$ in order to compare different brands. The coatings used in these tests were electrogalvanized (EG), Continuous HDG (GI), Galvanneale ${ }^{(*)}(\mathrm{GA})$ and Galfan (Galf) (7 $\mu \mathrm{m}$ thickness for all). From this work and according to this thesis scope, only field tests for $\mathrm{ZM}$ and $\mathrm{Z}$ finishes has been analysed.

(*) Note: Galvanneal is a carbon steel, coated with an alloy of zinc and iron. This type of coating is widely used in automotive sector.

Table 30 shows a sum-up of the test as well as the corrosion rates results measured.

Table 30: Field test \#3 summary and corrosion rate

\begin{tabular}{|c|c|c|c|c|c|c|c|}
\hline \multirow{2}{*}{$\begin{array}{l}\text { Coating } \\
\text { type }\end{array}$} & \multirow[b]{2}{*}{ Exposure } & \multicolumn{2}{|c|}{ Brest (France) } & \multirow{2}{*}{\multicolumn{2}{|c|}{$\frac{\text { Dortmund (Germany) }}{\text { Corrosivity class C3 }}$}} & \multicolumn{2}{|c|}{ Linz (Austria) } \\
\hline & & \multicolumn{2}{|c|}{ Corrosivity class C4 } & & & \multicolumn{2}{|c|}{ Corrosivity class C3 } \\
\hline \multirow{2}{*}{ PG } & Year 1 & \multirow{2}{*}{3.1} & 1,78 & \multirow{2}{*}{3.7} & 0,75 & \multirow{2}{*}{3.13} & 0,47 \\
\hline & Year 2 & & 1,95 & & 1,63 & & 0,86 \\
\hline \multirow{2}{*}{$\mathrm{EZ}$} & Year 1 & \multirow{2}{*}{3.1} & 1,66 & \multirow{2}{*}{3.7} & 0,96 & \multirow{2}{*}{3.13} & 0,57 \\
\hline & Year 2 & & 2,63 & & 1,82 & & 1,07 \\
\hline \multirow{2}{*}{ ZM1 } & Year 1 & \multirow{2}{*}{3.1} & 1,21 & \multirow{2}{*}{3.7} & 0,5 & \multirow{2}{*}{3.13} & 0,3 \\
\hline & Year 2 & & 1,62 & & 1,2 & & 0,52 \\
\hline \multirow{2}{*}{ ZM1,5 } & Year 1 & \multirow{2}{*}{3.2} & 0,87 & \multirow{2}{*}{3.8} & 0,53 & \multirow{2}{*}{3.14} & 0,17 \\
\hline & Year 2 & & 1,14 & & 0,78 & & 0,43 \\
\hline \multirow{2}{*}{ ZM2 } & Year 1 & \multirow{2}{*}{3.3} & 0,86 & \multirow{2}{*}{3.9} & 0,36 & \multirow{2}{*}{3.15} & 0,13 \\
\hline & Year 2 & & 1,28 & & 0,79 & & 0,3 \\
\hline
\end{tabular}

- Conclusions:

A higher relative corrosion performance $(\mathrm{Z} / \mathrm{ZM})$ is observed in environments involving high chloride load compared to conventional zinc coatings $(Z)$. The time to red rust was indeed delayed by a factor of 8-10 compared to HDG in open samples (not bended).

The good performance of ZM coatings is less obvious in accelerated corrosion tests with lower salt load. This effect is the same when it comes to field tests.

No major differences were observed between samples when varying $\mathrm{Al}$ and $\mathrm{Mg}$ content in the metallic coating. $\mathrm{ZM}$ alloys are more affected than $\mathrm{PG}$ in low $\mathrm{CO}_{2}$ conditions (no buffering of surface $\mathrm{pH}$ ). 
The corrosion performance of ZMA versus HDG may be linked to the microstructure and better stability of surfaces $\mathrm{pH}$ at cathodes.

\section{Field Test \#4}

- Locations: $\quad$ France North coast

Germany

Austria

- Corrosivity categories: C2, C3

- Exposure years:

\section{2}

- Tested materials:

PG $\quad 275 \mathrm{~g} / \mathrm{m}^{2}$

EZ $\quad 7 \mu \mathrm{m}$

$\mathrm{ZM} \quad \mathrm{Zn}-(1-3) \% \mathrm{Al}-(1-3) \% \mathrm{Mg}$

- Test Year:

2013

- Related references:

- "Corrosion performance of $\mathrm{Zn}-\mathrm{Mg}$ - $\mathrm{Al}$ coated steel in accelerated corrosion tests used in the automotive industry and field exposures" (LeBozec et al., 2012, 2013).

- "Alternative materials for Cable trays systems" (Swerea Kimab, 2014)

- Summary:

Swerea Kimab (Sweden) performed a research work to analyse alternative materials to traditional zinc coatings from which it was extracted a maximum-minimum ranges values for field tests, in 3 different locations: North of France, Germany and Austria. The coatings used in these tests were electrogalvanized (EG), Continuous HDG (GI) and different ZM alloys which composition varied from 1 to $3 \%$ for $\mathrm{Al}$ and from 1 to $3 \%$ as well, for magnesium. It only has been extracted results for open panels.

Table 31 shows a sum-up of the test as well as the corrosion rates results measured.

Table 31: Field test \#4 summary and corrosion rate

\begin{tabular}{|c|c|c|c|c|c|c|c|}
\hline \multirow{2}{*}{$\begin{array}{l}\text { Coating } \\
\text { type }\end{array}$} & \multirow{2}{*}{ Exposure } & \multicolumn{2}{|c|}{$\begin{array}{l}\text { France (north coast) } \\
\text { Corrosivity class } C 3\end{array}$} & \multicolumn{2}{|c|}{ Germany } & \multicolumn{2}{|c|}{ Austria } \\
\hline & & $\begin{array}{l}\text { Corro } \\
\text { Code }\end{array}$ & $\frac{\text { class C3 }}{\text { Rate }(\mu \mathrm{m})}$ & $\begin{array}{l}\text { Corr } \\
\text { Code }\end{array}$ & $\begin{array}{l}\text { y class C3 } \\
\text { Rate }(\mu \mathrm{m})\end{array}$ & $\begin{array}{l}\text { Corro } \\
\text { Code }\end{array}$ & Rate $(\mu \mathrm{m})$ \\
\hline \multirow{2}{*}{ PG } & Year 1 & 41 & 1,8 & \multirow{2}{*}{4.2} & 0,7 & \multirow{2}{*}{4.3} & 0,5 \\
\hline & Year 2 & 4.1 & 2,8 & & 1,5 & & 0,9 \\
\hline \multirow{2}{*}{$\mathrm{EZ}$} & Year 1 & & 1,7 & \multirow{2}{*}{4.2} & 1 & \multirow{2}{*}{4.3} & 0,6 \\
\hline & Year 2 & 4.1 & 3 & & 1,8 & & 1,1 \\
\hline \multirow{2}{*}{$\mathrm{ZM}$} & Year 1 & 41 & 1,05 & \multirow{2}{*}{4.2} & 0,45 & \multirow{2}{*}{4.3} & 0,2 \\
\hline & Year 2 & 4.1 & 1,75 & & 0,95 & & 0,42 \\
\hline
\end{tabular}

- Conclusions:

$\mathrm{ZM}$ behaves better in general in the 3 locations for both 1 and 2 years. Is also observed that in the location with a higher salt condensation (coastal); the ratio of performance between zinc coatings and ZM is 1,7 approximately in France and it reaches up to 2,6 in Austria when it comes to EZ vs ZM.

\section{$\underline{\text { Field Test \#5 }}$}

- Locations:

La Voz station (Venezuela)

- Corrosivity categories: CX

- Exposure years:

2

- Tested materials:

PG

HDG -

- Test Year:

2009

- Related references:

- "Evaluating Zn, Al and Al-Zn coatings on carbon steel in a special atmosphere" (de Rincón et al., 2009). 
- Summary:

This paper presents a comparative evaluation of $\mathrm{Al}, \mathrm{Zn}$ and $\mathrm{Al}-\mathrm{Zn}$ coatings on carbon steel, exposed to a coastalmarine atmosphere, inside the so-called Patina project. It is a very aggressive atmosphere with high wind velocities (corrosion-erosion rate \% 1,4 mm/year (55,12 mpy) for ASTM 1029 steel). Two flame spraying zinc coatings with pore sealers were also evaluated. ISO and ASTM standards were used for the evaluation.

Despite being an excellent protection against atmospheric corrosion, it is justified that aluminium as such is not the ideal protection due to its zero protection against galvanic corrosion due to the action of Al2O3, since it constitutes a semi-amorphous layer that barely has electrical conductivity. That is why, when alloyed with zinc, it acquires better characteristics for atmospheric corrosion resistance.

In general terms, the article carries out an evaluation of different coatings based on $\mathrm{Zn}$ and $\mathrm{Zn} / \mathrm{Al}$ alloys, with different proportions and coating methods, exposed to a very aggressive environment rated higher than C5 (Very high-Extreme), according to the standard ISO 9223 (ISO, 2012). The exposure time was 24 months with standard flat specimens and with a scratch to show galvanic protection.

Table 32 shows a sum-up of the test as well as the corrosion rates results measured.

Table 32: Field test \#5 summary and corrosion rate

\begin{tabular}{cccccc}
\multirow{2}{*}{ Test code } & Location & Environment & Corrosivity Category & \multicolumn{2}{c}{ Corrosion rate $(\mu \mathrm{m})$} \\
\cline { 5 - 6 } & & \multicolumn{2}{c}{ HDG } & PG \\
\hline 5.1 & $\begin{array}{c}\text { La Voz station } 2 \\
(\text { Venezuela) }\end{array}$ & Marine extreme & CX & 18 & 18,5 \\
\hline
\end{tabular}

- Conclusions:

a) One of the main conclusions of the article is, in general, the best behaviour of zinc coatings when they are alloyed with aluminium, for this type of atmosphere (aggressive coastal environment). TLR (thickness loss rate), for the alloy with 5\% aluminium, is significantly lower than the rest of coatings in $\mathrm{Zn}$ (never higher than $15 \mu \mathrm{m})$.

- Other research works (Panossian et al., 2005), arrived to similar conclusions, confirming that coatings based on zinc or zinc alloys with a high aluminium content (above 15\%), only provide effective cathodic protection against corrosion, in atmospheres with a high concentration level of chlorine ions, while alloys with high zinc content, the cathodic protection acts from the beginning in all cases.

- The mass loss has been measured only for continuous galvanizing, for non-continuous galvanizing and for zinc-based alloy $\mathrm{Zn} 5 \mathrm{Al}$. A continuous measurement of mass loss for aluminium-based alloys is not performed. Only for zinc-based coatings. The authors justify that the localized corrosion of aluminium does not make this measurement appropriate. In any case, it is remarkable as the TLR (thickness loss rate) for the alloy with 5\% aluminium, it is significantly lower than the rest of coatings in $\mathrm{Zn}$ (never exceeding $15 \mathrm{~mm})$.

- The different TLRs that vary from year to year show how effectively, the rate of mass loss is not linear, as is the case with zinc-based coatings, as evidenced by the research work that precedes this thesis (Chenoll Mora, 2005).

- The environmental conditions of the tests have been carried out in CX environment, as evidenced at the end of the test with the TLRs obtained, which falls within the margins established in ISO 9223 for this corrosivity category: $8.4 \leq \mathrm{r}_{\text {corr }} \leq 25$ (corrosion rate in $\mu \mathrm{m} /$ year). Zinc-based alloys with Aluminium and Magnesium are outside the evaluation range.

- The good performance in terms of the final result of discontinuous galvanizing, even having higher TLR than aluminium alloys, is due, on one hand to its high thickness and on the other hand, to the greater resistance of the 4 interdendritic layers, thanks to the presence of $\mathrm{Fe} / \mathrm{Zn}$ in the first 3 layers.

\section{$\underline{\text { Field Test \#6 }}$}

$\begin{array}{ll}\text { - Locations: } & \text { Brest (France) } \\ & \text { Chicago (USA) } \\ & \text { Mazières (France) } \\ \text { - Corrosivity categories: } & \text { C3, C4 }\end{array}$


- Exposure years: 2

$\begin{array}{lll}\text { - Tested materials: } & \text { PG } & 20 \mu \mathrm{m} \\ & \mathrm{ZM} & \mathrm{ZnMg} 3 \% \mathrm{Al} 3,7 \% \\ \text { - Test Year: } & 2015 & \end{array}$

- Related references:

- "Corrosion mechanisms of $\mathrm{Zn}(\mathrm{Mg}, \mathrm{Al})$ coated steel in accelerated tests and natural exposure: 1 . The role of electrolyte composition in the nature of corrosion products and relative corrosion rate" (Salgueiro Azevedo et al., 2015a).

- "Corrosion mechanisms of $\mathrm{Zn}(\mathrm{Mg}, \mathrm{Al})$ coated steel: 2. The effect of $\mathrm{Mg}$ and $\mathrm{Al}$ alloying on the formation and properties of corrosion products in different electrolytes" (Salgueiro Azevedo et al., 2015b)

- Summary:

The main aim of this paper is to highlight the effect of the electrolyte composition used in corrosion tests, when comparing to field tests performance. A new test electrolyte is proposed, containing $\mathrm{NH}_{4}{ }^{+}$and $\mathrm{HCO}_{3}{ }^{-}$, which shows an improved correlation with field exposure in particular respecting the relative corrosion rates and the absence or at least delayed formation of layered double hydroxides. With the aim of compare this correlation between accelerated corrosion tests and field tests, 3 different field tests were arranged for 2 years duration in 3 different locations. It has been used 3 different type of materials: PG (hot dip galvanized steel sheet), ZA (Zinc/Aluminium) and ZM (Zinc/Aluminium/Magnesium). The results of this field tests have been used for this thesis purpose and they are reflected in Table 33.

Table 33: Field test \#6 summary and corrosion rate

\begin{tabular}{|c|c|c|c|c|c|c|c|}
\hline \multirow{3}{*}{$\begin{array}{l}\text { Coating } \\
\text { type }\end{array}$} & \multirow{3}{*}{ Exposure } & \multirow{2}{*}{\multicolumn{2}{|c|}{$\begin{array}{c}\text { Brest (France) } \\
\text { Corrosivity class C4 }\end{array}$}} & \multirow{2}{*}{\multicolumn{2}{|c|}{$\begin{array}{c}\text { Chicago (USA) } \\
\text { Corrosivity class C3 }\end{array}$}} & \multirow{2}{*}{\multicolumn{2}{|c|}{$\begin{array}{c}\text { Mazières (France) } \\
\text { Corrosivity class C3 }\end{array}$}} \\
\hline & & & & & & & \\
\hline & & Code & Rate $(\mu \mathrm{m})$ & Code & Rate $(\mu \mathrm{m})$ & Code & Rate $(\mu \mathrm{m})$ \\
\hline PG & Year 2 & 6.1 & 2,9 & 6.2 & 1,4 & 6.3 & 1 \\
\hline $\mathrm{ZM}$ & Year 2 & 6.1 & 1,2 & 6.2 & 0,5 & 6.3 & 0,3 \\
\hline
\end{tabular}

- Conclusions:

- It is proven the better performance of $\mathrm{ZM}$ alloys in high chloride content environments, but its performance is lower in more neutral atmospheres, which was evidenced by tests carried out using distilled rainwater as an electrolyte.

- Corrosion mechanisms in accelerated tests differ significantly in function of the electrolyte composition. In this article has been showed that when using rainwater as electrolyte, the ratio of performance between $\mathrm{Zn}$ and $\mathrm{ZM}$ alloys is closer to real performance, thanks to the field tests arranged.

- The corrosion products are key for the corrosion process and those are quite dependent on the electrolyte, as well as on the alloy composition. The corrosion products varied also with the electrolyte composition.

- The performance of ZM alloys using rainwater electrolyte is much lower than using $\mathrm{NaCl}$.

- After all accelerated tests as well as after 2 years of field exposure in 3 different sites, ZM coating with 3 wt.\% of $\mathrm{Mg}$ and $3.7 \mathrm{wt} . \%$ of $\mathrm{Al}$ have shown a better corrosion resistance than PG (in terms of weight loss).

\section{$\underline{\text { Field Test \#7 }}$}

- Locations:

Bohus-Malmön (Sweden)

Wanning (China)

Yucatán (México)

- Corrosivity categories:

- Exposure years:

C4, C5, CX

- Tested materials:

1

HDG $50 \mu \mathrm{m}$

ZM1 $\quad \mathrm{Zn}(91 \%) / \mathrm{Mg}(6 \%) / \mathrm{Al}(3 \%)$

ZM2 ZnMg2\%A12\% 
- Related references:

- "The corrosion behavior of ZnAlMg alloys in maritime environments" (Tomandl \& Labrenz, 2016).

- Summary:

Two ZM alloys and hot dipped galvanized or pure cinc samples, were exposed to the atmosphere in maritime environments in Mexico, China, and Sweden. The two alloys had different composition in terms of magnesium and aluminium percentages. The article shows results for corrosion rate of 1 year. The results of this field tests are reflected in Table 34,

Table 34: Field test \#7 summary and corrosion rate

\begin{tabular}{|c|c|c|c|c|c|c|c|}
\hline \multirow{3}{*}{$\begin{array}{l}\text { Coating } \\
\text { type }\end{array}$} & \multirow{3}{*}{ Exposure } & \multirow{2}{*}{\multicolumn{2}{|c|}{ Bohus Malmon (Sweden) }} & \multirow{2}{*}{\multicolumn{2}{|c|}{$\frac{\text { Wanning (China) }}{\text { Corrosivity class C5 }}$}} & \multicolumn{2}{|c|}{ Yucatán (México) } \\
\hline & & & & & & Corro & class CX \\
\hline & & Code & Rate $(\mu \mathrm{m})$ & Code & Rate $(\mu \mathrm{m})$ & Code & Rate $(\mu \mathrm{m})$ \\
\hline HDG & Year 1 & 7.1 & $1-3$ & 7.3 & $3-5$ & 7.5 & $10-15$ \\
\hline ZM1 & Year 1 & 7.1 & 2 & 7.3 & $1-2$ & 7.5 & $4-6$ \\
\hline $\mathrm{ZM} 2$ & Year 2 & 7.2 & $3-4$ & 7.4 & $2-3$ & 7.6 & $5-6$ \\
\hline
\end{tabular}

\title{
- Conclusions:
}

$\mathrm{ZM}$ samples showed a better corrosion resistance rates compared to $\mathrm{Zn}$ coating, even the analysis was done for 1 year. Even only this 1-year analysis, this article has been considered in this research work, to support statistics, when analysing 1-year behaviour together with other field tests results. The article also gives some clues about the behaviour of cut edges regarding corrosion, stating that the that protection is given by self-healing, up to $2 \mathrm{~mm}$ thickness and in low corrosivity coastal environments.

\section{Field Test \#8}

- Locations

\author{
Brest (France) \\ Wanning (China) \\ Daytona beach (USA) \\ Sattaship (Thailand) \\ Bohus-Malmön Kattesand (Sweden) \\ Bohus-Malmön Kvarnvik (Sweden) \\ Ijmuiden (The Netherlands) \\ Qingdao (China) \\ Singapore \\ Dubai (Arabian Emirates United) \\ Cádiz (Spain) \\ Ostrawa (Czech Republic) \\ Bangkok (Thailand) \\ Jiangjin (China)
}

- Corrosivity categories: C2, C3, C4, C5

- Exposure years:

4

- Tested materials:

PG $\quad 275 \mathrm{~g} / \mathrm{m}^{2}$

$\mathrm{ZM} \quad \mathrm{ZnMg} 2 \% \mathrm{Al} 2 \%$

- Test Year:

2011 - 2014

- Related references:

- "Corrosion and corrosion products of hot dipped galvanized steel during long term atmospheric exposure at different sites world-wide" (Persson, Thierry, \& Karlsson, 2017). This reference shows tests for 2 years exposure.

- "Atmospheric corrosion of ZnAlMg coated steel during long term atmospheric weathering at different worldwide exposure sites" (Dominique Thierry, Persson, Luckeneder, \& Stellnberger, 2019). This reference shows tests for 4 years exposure. 
- Summary:

It has been arranged one specific field test at different sites world-wide, which results were split in 2 different parts:

- $\quad$ Part I: After 2 Years exposure, for PG

- $\quad$ Part II: After 4 years exposure for PG and ZM

The results of this field tests are reflected in Table 35 .

Table 35: Field test \#8 summary and corrosion rate

\begin{tabular}{|c|c|c|c|c|c|c|c|c|c|}
\hline \multirow{3}{*}{ Test code } & \multirow{3}{*}{ Location } & \multirow{3}{*}{ Environment } & \multirow{3}{*}{$\begin{array}{l}\text { Corrosivity } \\
\text { Category }\end{array}$} & \multicolumn{6}{|c|}{ Corrosion rate $(\mu \mathrm{m})$} \\
\hline & & & & \multicolumn{3}{|c|}{ PG } & \multicolumn{3}{|c|}{$\mathrm{ZM}$} \\
\hline & & & & Year 1 & Year 2 & Year 4 & Year 1 & Year 2 & Year 4 \\
\hline 8.1 & Brest (France) & Marine & $\mathrm{C} 3$ & 1,29 & 2,16 & 4,62 & 0,31 & 1,15 & 2,35 \\
\hline 8.2 & Wanning (China) & Marine & $\mathrm{C} 4$ & 2,80 & 4,69 & 7,23 & 1,09 & 1,58 & 4,15 \\
\hline 8.3 & Daytona beach (USA) & Marine & $\mathrm{C} 4$ & 1,61 & 4,02 & 4,36 & 0,38 & 1,03 & 2,14 \\
\hline 8.4 & Sattaship (Thailand) & Marine & $\mathrm{C} 3$ & 0,90 & 1,52 & $1,91^{(*)}$ & 0,2 & 0,28 & $0,85^{(*)}$ \\
\hline 8.5 & $\begin{array}{l}\text { Bohus-Malmön } \\
\text { (Kattesand) }\end{array}$ & Marine & $\mathrm{C} 3$ & 1,63 & 2,57 & 5,45 & 0,62 & 0,91 & 2,15 \\
\hline 8.6 & $\begin{array}{l}\text { Bohus-Malmön } \\
\text { (Kvarnvik) }\end{array}$ & Marine & $\mathrm{C} 5$ & 2,56 & 5,15 & 7,8 & 1,11 & 1,32 & 4,02 \\
\hline 8.7 & $\begin{array}{l}\text { Ijmuiden (The } \\
\text { Netherlands) }\end{array}$ & $\begin{array}{l}\text { Marine / } \\
\text { Industrial }\end{array}$ & $\mathrm{C} 3$ & 1,02 & 1,66 & 3,43 & 0,34 & 1,05 & 1,89 \\
\hline 8.8 & Qingdao (China) & $\begin{array}{l}\text { Marine / } \\
\text { Industrial }\end{array}$ & $\mathrm{C} 3$ & 1,33 & 3,54 & 5,81 & 0,71 & 1,74 & 2,89 \\
\hline 8.9 & Singapore & $\begin{array}{l}\text { Marine / } \\
\text { Urban }\end{array}$ & $\mathrm{C} 3$ & 2,02 & 3,59 & 6,09 & 0,82 & 1,60 & 3,38 \\
\hline 8.10 & Dubai (AEU) & $\begin{array}{l}\text { Marine / } \\
\text { Urban }\end{array}$ & $\mathrm{C} 4$ & 2,12 & 3,45 & 6,66 & 0,52 & 1,58 & 3,35 \\
\hline 8.11 & Cádiz (Spain) & $\begin{array}{l}\text { Marine / } \\
\text { Urban }\end{array}$ & $\mathrm{C} 3$ & 0,60 & 0.91 & 1,80 & 0,28 & 0,43 & 1,20 \\
\hline 8.12 & $\begin{array}{l}\text { Ostrawa (Czech } \\
\text { Republic) }\end{array}$ & $\begin{array}{l}\text { Industrial / } \\
\text { Urban }\end{array}$ & $\mathrm{C} 3$ & 0,92 & 1,66 & - & 0,46 & 0,78 & - \\
\hline 8.13 & Bangkok (Thailand) & $\begin{array}{l}\text { Industrial / } \\
\text { Urban }\end{array}$ & $\mathrm{C} 2$ & 0,50 & 1 & 2,67 & 0,09 & 0,20 & 0,92 \\
\hline 8.14 & Jiangjin (China) & Industrial & $\mathrm{C} 3$ & 1,25 & 2,25 & 3,98 & 0,65 & 1,49 & 2,51 \\
\hline
\end{tabular}

(*) Corrosion values for 3 years

- Conclusions:

The measured mass loss of ZM coating was lower than PG for all sites, independently on the climatic conditions. The ratio the mass loss after 4 years between PG and ZM after 4 years had a mean value of 2,2. After, corrosion products have been evaluated, but are not related to the scope of this thesis.

\section{Field Test \#9}

- Location:

Brest (France)

- Corrosivity categories: C3

- Exposure years: 2

- Tested materials: $\quad$ PG $20,7 \mu \mathrm{m}$

ZM1 ZnMg1,49\%A12,72\%

ZM2 $\mathrm{ZnMg} 1,51 \% \mathrm{~A} 12,71 \%$

ZM3 ZnMg1,51\%Al2,67\%

$\mathrm{ZM} \quad \mathrm{ZnMg} 1,6 \% \mathrm{Al} 2,9 \%$ (reference $\mathrm{ZM}$ )

- Test Year: $2017-2018$

- Related references:

- "Influence of microstructure of zinc-aluminium-magnesium alloy coated steel on the corrosion behaviour in outdoor marine atmosphere" (LeBozec et al., 2019). 
- Summary:

In this field test were tested samples of 3 different ZM alloys, with different microstructures and composition, that were generated using a galvanising simulator by varying the after-pot cooling rate. The corrosion properties of the model microstructures were investigated in outdoor marine atmosphere for 2 years. Samples of standard ZM alloy and traditional hot dip galvanized (PG) were also tested as references. Results are shown in Table 36.

Table 36: Field test \#9 summary and corrosion rate

\begin{tabular}{ccccccc}
\multirow{2}{*}{ Test code } & Coating type & Location & Environment & Corrosivity class & \multicolumn{2}{c}{ Corrosion rate $(\mu \mathrm{m})$} \\
\cline { 5 - 7 } & & & & Year 1 & Year 2 \\
\hline 9.1 & PG & Brest & Marine & C3 & 0,92 & 1,66 \\
9.1 & ZM1 & Brest & Marine & C3 & 0,51 & 1,08 \\
9.2 & ZM2 & Brest & Marine & C3 & 0,34 & 0,68 \\
9.3 & ZM3 & Brest & Marine & C3 & 0,65 & 0,85 \\
9.4 & ZM & Brest & Marine & C3 & 0,54 & 0,71 \\
\hline
\end{tabular}

Figure 24, extracted from said reference, shows the evolution of the mass loss more in detail, splitted by periods of 3,12 and 24 months.

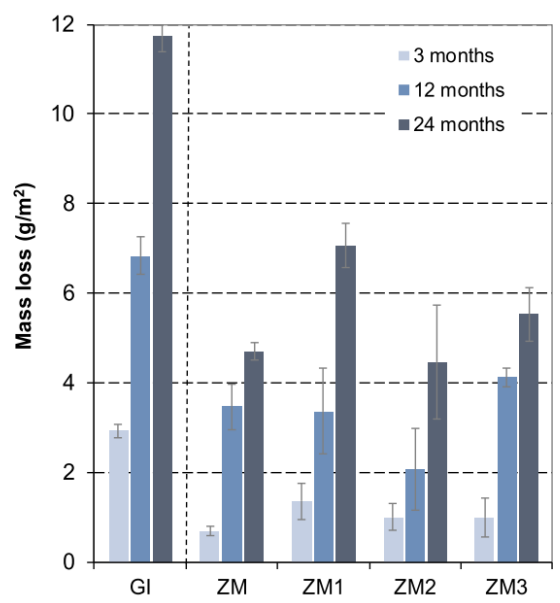

Figure 24: Evolution of mass loss from 3 to 24 months

- Conclusions:

It is observed similar results in terms of corrosion rate of ZM alloys in front of PG, with a performance ratio that varies between 2,4 to 1,5 . Weight loss measurements and cross section observations revealed a tendency for fine microstructures enriched in eutectic phases to be the most corrosion resistant. Finally, it seems that there may be a lower limit in the size of zinc grains or a negative influence of the new formed phase AlMg4Zn11 for which the improvement is no longer observed. Deeper investigations shall however be conducted to better understand this point.

\title{
$\underline{\text { Field Test \#10 }}$
}

- Locations:

\author{
Brest (France) \\ Wanning (China) \\ Daytona beach (USA) \\ Bohus-Malmön Kattesand (Sweden) \\ Bohus-Malmön Kvarnvik (Sweden) \\ Ijmuiden (The Netherlands) \\ Qingdao (China) \\ Singapore \\ Dubai (Arabian Emirates United) \\ Cádiz (Spain) \\ Bangkok (Thailand)
}

- Corrosivity categories: C2, C3, C4, C5 
- Exposure years:

- Tested materials:

- Test Year:

- Related references:

- "Long-term atmospheric corrosion rates of hot dip galvanised steel and zinc-aluminum-magnesium coated steel” (Dominique Thierry, LeBozec, Le Gac, \& Persson, 2019b).

\section{- Summary:}

This is the field test with longer exposure time: 6 years. So, it is the most valuable field test in this thesis, since it allows not only, larger tests results, but also the trend of corrosion in a longer perspective time. Pre-galvanized and ZM alloys were tested and Table 37, shows the results.

Table 37: Field test \#10 summary and corrosion rate

\begin{tabular}{clrrrrrrrr} 
& & \multicolumn{8}{c}{ Corrosion rate $(\mu \mathrm{m})$} \\
\cline { 2 - 9 } Test code & \multicolumn{1}{c}{ Location $^{*}$ ) } & \multicolumn{9}{c}{ PG } & \multicolumn{7}{c}{ ZM } \\
\cline { 2 - 9 } & & Year 1 & Year 2 & Year 4 & Year 6 & Year 1 & Year 2 & Year 4 & Year 6 \\
\hline 10.1 & Brest (France) & 1,29 & 2,16 & 4,62 & 8,73 & 0,32 & 0,97 & 1,61 & 2,90 \\
10.2 & Wanning (China) & 2,80 & 4,69 & 7,23 & 16,19 & 1,29 & 1,45 & 2,90 & 6,29 \\
10.3 & Daytona beach (USA) & 1,61 & 4,02 & 4,36 & 10,28 & 0,32 & 0,65 & 1,61 & 2,10 \\
10.4 & Bohus-Malmön & 1,63 & 2,57 & 5,45 & 9,85 & 0,65 & 0,81 & 1,61 & 2,58 \\
& (Kattesand) & & & & & & & & \\
10.5 & Bohus-Malmön & 2,56 & 5,15 & 7,8 & 16,62 & 1,13 & 1,94 & 2,42 & 3,55 \\
& (Kvarnvik) & & & & & & & & \\
10.6 & Ijmuiden (The & 1,02 & 1,66 & 3,43 & 5,49 & 0,48 & 0,65 & 1,29 & 1,94 \\
& Netherlands) & & & & & & & & \\
10.7 & Qingdao (China) & 1,33 & 3,54 & 5,81 & 12,25 & 0,65 & 0,97 & 1,61 & 3,39 \\
10.8 & Singapore & 2,02 & 3,59 & 6,09 & 10,8 & 0,65 & 1,29 & 2,90 & 6,13 \\
10.9 & Dubai (AEU) & 2,12 & 3,45 & 6,66 & 10,98 & 0,48 & 0,65 & 2,58 & 7,26 \\
10.10 & Cádiz (Spain) & 0,60 & 0.91 & 1,80 & 3,52 & 0,32 & 0,65 & 1,61 & 2,10 \\
10.11 & Bangkok (Thailand) & 0,50 & 1 & 2,67 & 5,63 & 0,32 & 0,16 & 0,81 & 1,45 \\
\hline
\end{tabular}

(*) Type of environment and corrosivity category are the same that showed in Table 35.

- Conclusions:

The main conclusion is that ZM showed a better corrosion performance than Z275 after 6 years of exposure in all sites. The authors also highlight that "The ratio of improvement of ZM3.7/3 to $\mathrm{Z}$ varied after 6 years from about 1.4 to 4.4 upon the exposure location (mean value of 10 sites at 2.8)". This is relevant considering that one of the key questions to answer in this thesis is the way this ratio evolutions along the time, and it is a question that will be analysed in the coming chapters of this thesis.

\section{METHODOLOGYCAL FRAMEWORK}

\subsection{Introduction}

Having analysed the state of the art in the previous chapter, the selected methodological framework, on which underlies the contributions that underwrite this doctoral thesis, will be presented below.

The methodology followed will be divided fundamentally into two main blocks:

- Block I: Analysis of the field tests previously reviewed in the Background chapter.

- Block II: Long-term corrosion prediction

In both blocks, the methodology will always focus on a comparison between traditional zinc-based coatings and the new proposed alloys. Likewise, said methodology will be structured on the basis of the analysis of the 6 corrosivity categories internationally recognized by the ISO 9223 standard (C1 to CX), which was also previously analysed in the background chapter. 


\subsection{Block I: General analysis}

\subsubsection{Classification of field tests results}

In this first part of the methodology all the data compiled in the chapter 2.11 Field corrosion tests on $Z$ and $Z M$ alloys coatings has to be classified, according to:

- Geographical location

- Corrosivity category according to ISO 9223. This corrosivity category can be determined either, because it is already done in the research articles referenced or using the first year corrosion rate as the criterion used by ISO 9223 (see Table 11: Corrosion rates for zinc, rcorr, expressed in $\mu m \cdot a-1$ for the first year of exposure for the different corrosivity categories ISO 9223)

- $\quad$ Raw material designation, according to the standards described in 2.6 Relevant international standards covering ZM coatings.

- Corrosion rate for each of the years of the arranged tests in $\mu \mathrm{m}$. These will be the values that will be used to statistically analyse the behaviour of corrosion over time in the following steps of the methodology

This classification will be done for zinc-based coatings (Z) and zinc-aluminium-magnesium coatings (ZM), in order to have a comparative analysis of the performance of both types of coating.

\subsubsection{Filtering of results}

All the corrosion figures classified according to the previous clause, must be analysed, discarding those values which are clearly well below or well above the calculated mean values. Corrosion rate values are extracted from several tests arranged over many different samples. At the same time, not all samples have a regular finish in all their surface, thus, is normal that for some of these measurements could be found abnormal values far away from the mean values; those values have to be discarded to get a reliable later statistical analysis.

\subsubsection{Statistical analysis per ISO 9223 corrosivity categories}

A deep statistical analysis for each of the corrosivity categories must be performed, with the filtered corrosion rates results obtained from the previous clause. This analysis shall be the main entry point to determine the behaviour of the yearly corrosion rate for each of the corrosivity categories. At the same time, this analysis will be used to foresee the long-term corrosion rate in the second block of the methodology. It will be necessary to calculate the key statistical values like the average, the median, the standard deviation and the data distribution using for instance box plot charts.

This analysis will also allow uncertainty levels to be taken into account in the calculations of the long-term forecast of corrosion, so that they can be considered in the project by the designer.

\subsubsection{Average linear evolution of $\mathrm{Z}$ and $\mathrm{ZM}$ finishes}

Is especially relevant in this analysis, to see the evolution of the mean values of the corrosion ratio per year and by corrosivity category. This analysis will be especially valuable in comparing performance between ZM alloys and $\mathrm{Z}$ coatings. A graphical representation to check visually differences between corrosivity categories and Z/ZM finishes, will help substantially to understand the full performance picture.

\subsubsection{Ratios Z-ZM and Z/ZM}

These two ratios will be calculated to quantitatively establish the comparative difference between the $\mathrm{ZM}$ and $\mathrm{Z}$ coatings and see the variation of these parameters over the years and to what extent, this variation is the same for the different corrosivity categories.

\subsubsection{Behaviour of $\mathrm{ZM}$ during first year of exposure}

During the investigation of the state of the art, several articles promulgated mainly by galvanizer associations were found, in which it is intended to demonstrate that the effect of magnesium in ZM alloys against corrosion, is very important in the first years of exposure, but that as time passes this effect decreases and the behaviour becomes the same as for zinc treatments. This effect will be important to analyse in the face of the established methodology for calculating long-term corrosion. 


\subsection{Block 2: Long-term corrosion prediction}

\subsubsection{General approach}

For the long-term corrosion prediction up to 6 years, the values obtained from the real field tests will be used, for each corrosivity category.

From exposures of more than 6 years, and once all the statistical data previously analysed is available, the general expression for the evolution of corrosion will be applied:

This methodology will consist of:

$$
\mathrm{C}(\mathrm{t})=A t^{\mathrm{n}} \quad \text { (Equation 1) }
$$

a) Identify yearly corrosion for the first year of exposure (parameter $A$ ).

It will be estimated as the average of the different corrosion values in the field tests done for this first year of exposure.

b) Identify corrosion for each of the year of exposure. For instance, for year 2, $t$ parameter will adopt a value of 2 .

It will be estimated as the average of the different corrosion values in the field tests done for this second year of exposure.

c) Calculate $n$ parameter

Substitute $C$ (2) and $A$ in Equation 1 and clear $n$ parameter.

d) Substitute $n$ and $A$ parameters in Equation 1, to determine the long-term corrosion function.

e) Long-term corrosion can now be calculated, by substituting $t$ by the period for which the corrosion is to be known.

This methodology will be applied for each of the different values of $n$ given by each of the years analysed and for each corrosivity category. In the same way, it will be calculated as well, the average value of $n$ for each corrosivity category, which could bring a lower error that the individual values of $n$.

\subsubsection{Applications in projects calculations}

In this section the methodology proposed in the previous one will be described in detail through the usage of flowcharts, for its application in project-oriented calculations in which the selection of the most appropriate material is required, to ensure the prescribed guarantee periods or, on the contrary, to establish from a certain material, the maximum duration of the same at the location of the aforementioned project.

As a result, the proposed methodology will be splitted in 2 parts and inside each part, a specific methodology is dedicated to $\mathrm{Z}$ and $\mathrm{ZM}$ finishes:

Part I: Duration calculation from a given thickness coating

a) Zinc-based coatings

b) Zinc-Aluminium-Magnesium coatings

Part II: Corrosion calculation from a given exposition time

c) Zinc-based coatings

a) Zinc-Aluminium-Magnesium coatings

For each case, a specific methodology is expressed through the following flowcharts (Figure 25, Figure 26,

Figure 27, Figure 28): 


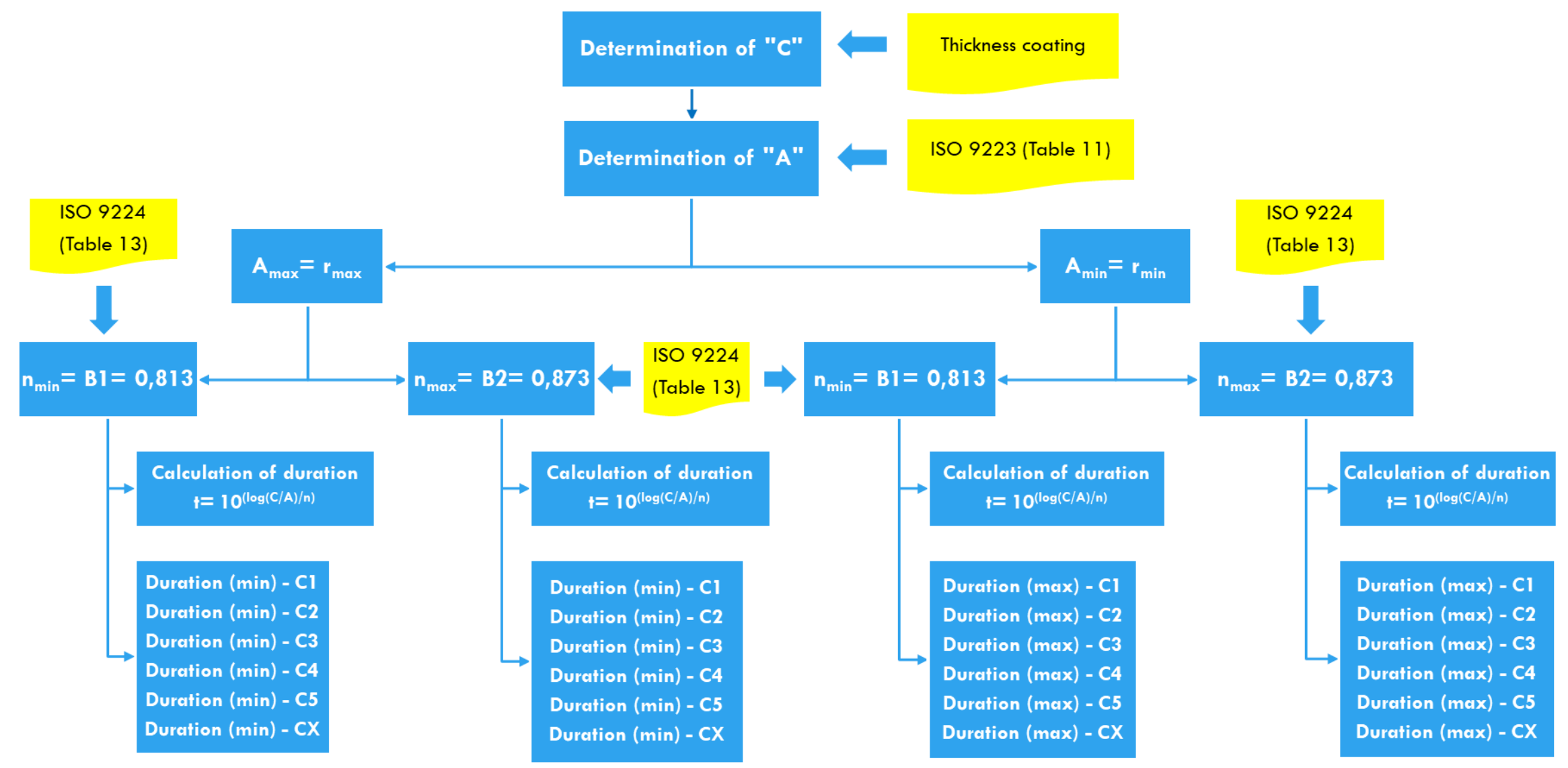

Figure 25: Methodology to choose the type of material. Part I: Duration calculation from a given thickness coating: $\mathrm{Z}$ finishes 


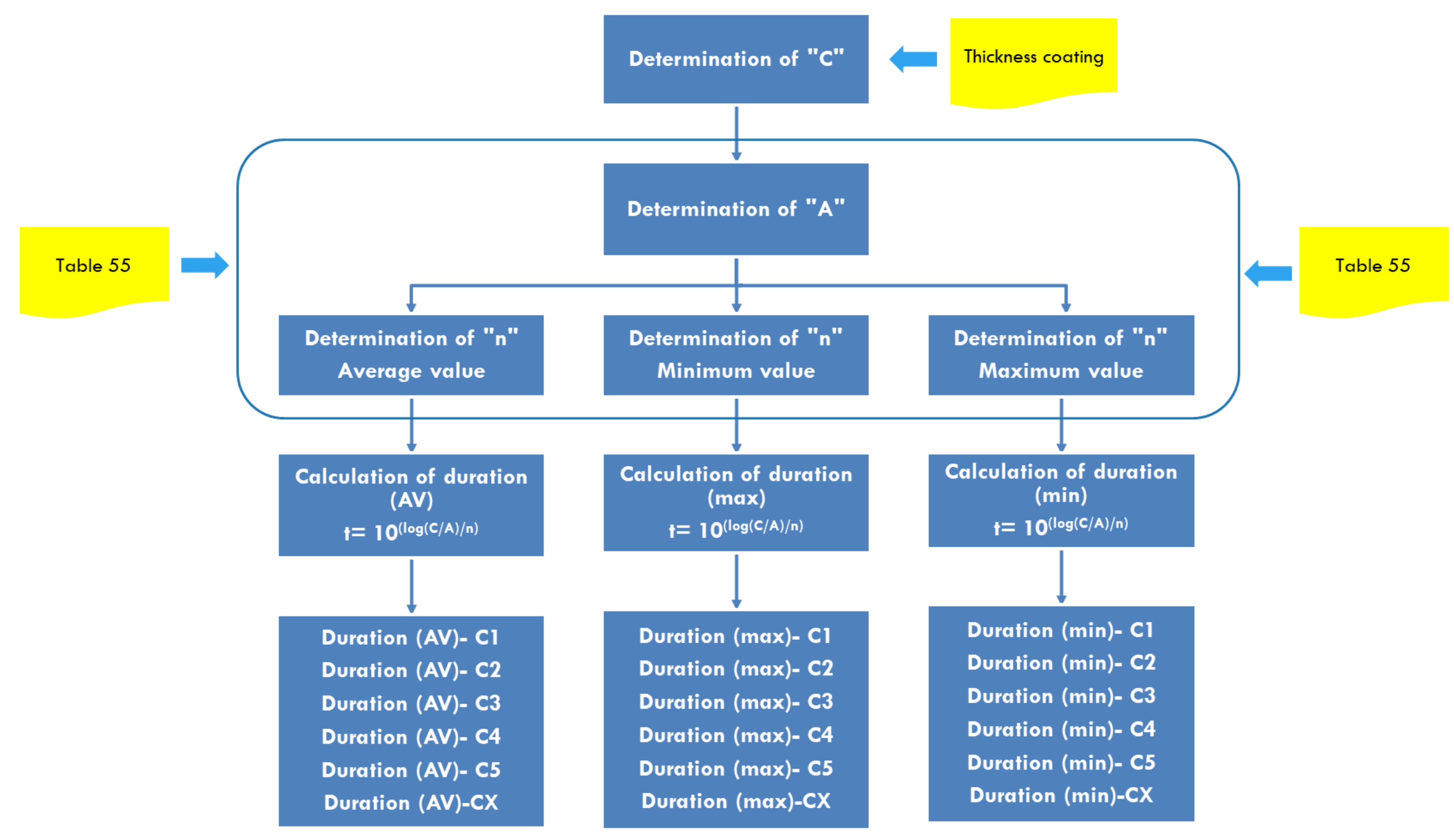

Figure 26: Methodology to choose the right material. Part I: Duration calculation from a given thickness coating: ZM finishes 


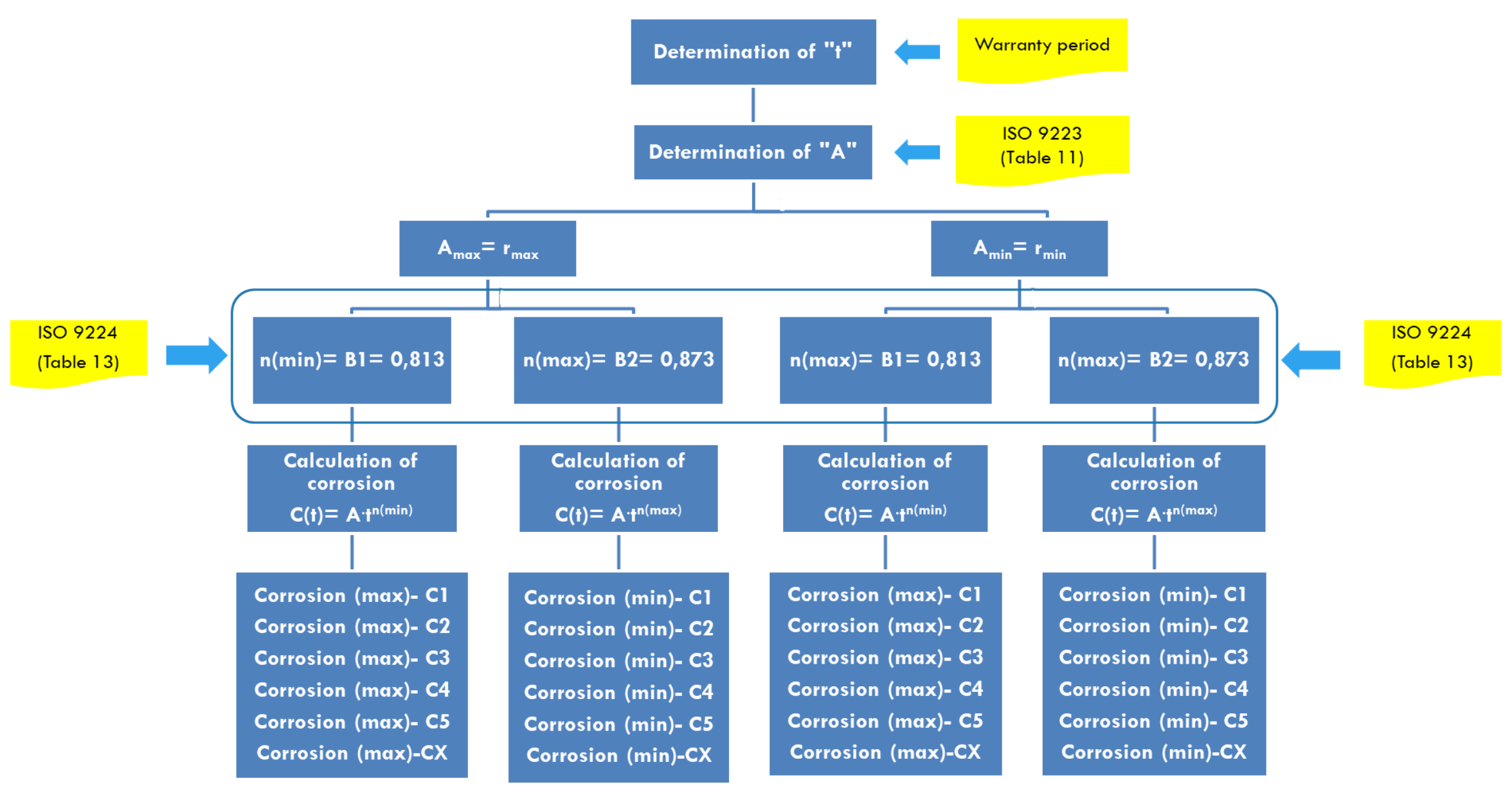

Figure 27: Methodology to choose the right material. Part II: Corrosion calculation from a given exposition time: $\mathrm{Z}$ finishes 


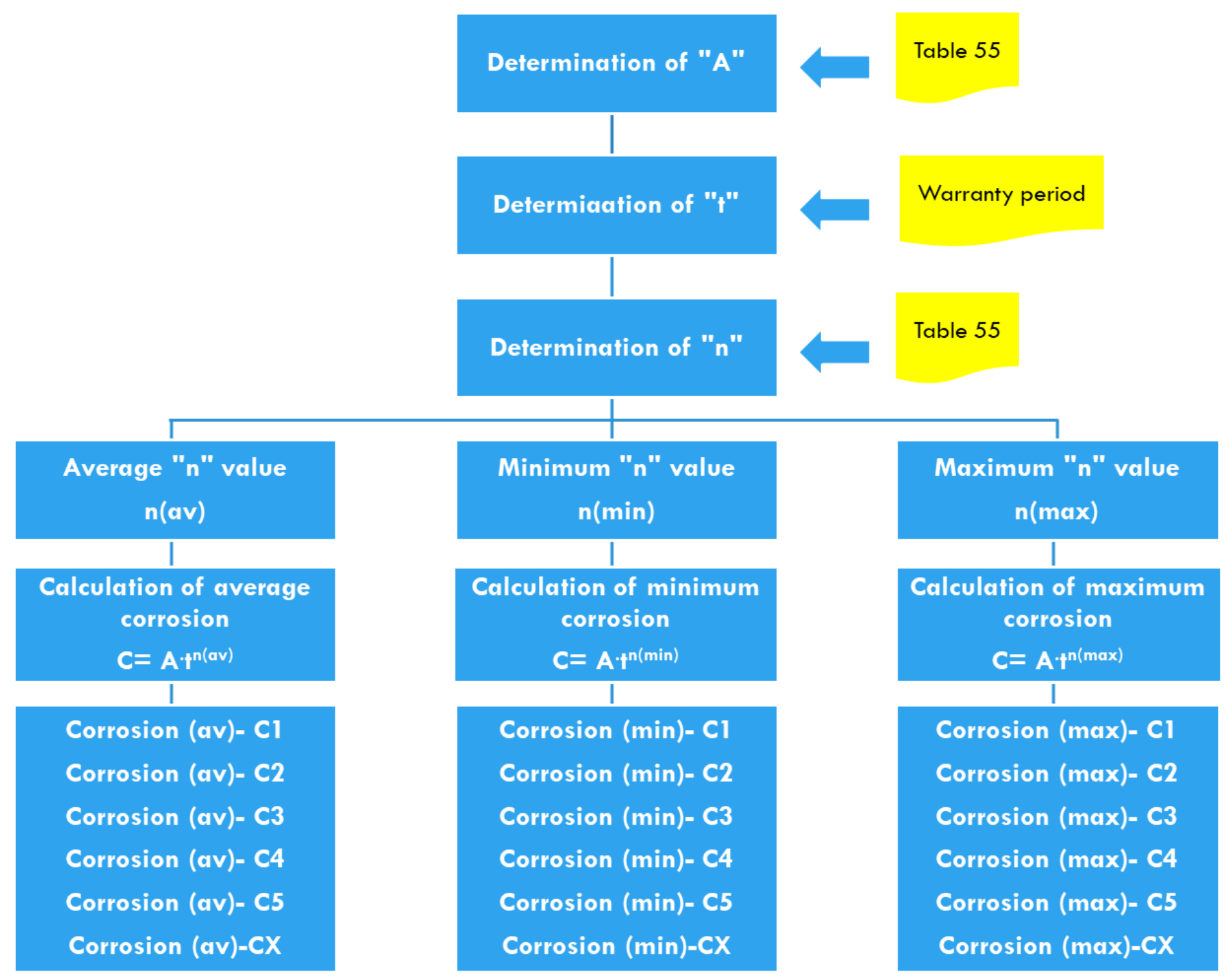

Figure 28: Methodology to choose the right material. Part II: Corrosion calculation from a given exposition time: ZM finishes 


\section{$4 \quad$ RESULTS AND DISCUSSIONS}

\subsection{General view of results classified by year and corrosivity class}

\subsubsection{Summary of field tests results}

Table 38 shows a summary of all the field tests results and it contains the sources as well from which the results have been obtained.

The corrosivity category ( $\mathrm{C} 1$ to $\mathrm{CX}$ ) has been determined considering the corrosion rate of zinc finishes for the first year of exposure, according to ISO 9223 (see Table 11). In those cases, in which more than one zinc coating is tested, the worst case (higher corrosivity rate) has been chosen.

In order to have a clear codification system to reference those tests, each of them has been designated with a numbering coding system. This system works like this:

source\#number.test\#number

Where the source corresponds to a common field test from a common source/s and test corresponds to the specific site where the test was performed or being the same site, the different types of alloys tested in it or being the same site and the same type of alloy, the different corrosivity category.

Example 1:

Test 7.1 - Corresponds to the source number 7 (Tomandl \& Labrenz, 2016) and the location 1, that corresponds to Bohus-Malmön (Sweden).

Example 2:

Test 3.1 - Corresponds to the source number 3 (Autocoat, 2013; LeBozec et al., 2013) and the location 1, that corresponds to Brest (France). The alloy tested is $\mathrm{ZnMg} 1 \% \mathrm{All} \%$.

Test 3.2 - Corresponds to the source number 3 (Autocoat, 2013; LeBozec et al., 2013) and the location 2, that corresponds also to Brest (France), but the alloy tested is $\mathrm{ZnMg} 1,5 \% \mathrm{Al1}, 5 \%$. 
Table 38: Field tests results summary of the different research works analysed

\begin{tabular}{|c|c|c|c|c|c|c|c|c|c|c|c|}
\hline \multirow{2}{*}{ Source reference } & \multirow{2}{*}{$\begin{array}{l}\text { Source } \\
\text { number }\end{array}$} & \multirow{2}{*}{ Test number } & \multirow{2}{*}{$\begin{array}{l}\text { Type of Environment } \\
\text { (as described in the test) }\end{array}$} & \multirow{2}{*}{ Location } & \multirow{2}{*}{$\begin{array}{c}\text { Corrosivity } \\
\text { category } \\
\text { ISO } 9223 \\
\end{array}$} & \multirow{2}{*}{ Material } & \multicolumn{5}{|c|}{ Corrosion rate $(\mu \mathrm{m})$} \\
\hline & & & & & & & Year 1 & Year 2 & Year 3 & Year 4 & Year 6 \\
\hline \multirow{11}{*}{$\begin{array}{l}\text { (Nordic } \\
\text { Galvanizers, n.d.; } \\
\text { Swerea Kimab, } \\
\text { 2014) }\end{array}$} & \multirow{11}{*}{1} & \multirow{2}{*}{1.1} & \multirow{2}{*}{ Marine - Open panels } & \multirow{2}{*}{$\begin{array}{l}\text { Bohus / Malmön - } \\
\text { Sweden }\end{array}$} & \multirow{2}{*}{$\mathrm{C} 3$} & HDG ISO1461 $(68 \mu \mathrm{m})$ & 1,6 & 2,8 & & & \\
\hline & & & & & & $\mathrm{Zn}(91 \%) / \mathrm{Mg}(6 \%) / \mathrm{Al}(3 \%)$ & 0,7 & 1,3 & & & \\
\hline & & \multirow{2}{*}{1.2} & \multirow{2}{*}{ Traffic tunnel } & \multirow{2}{*}{ Öresund - Sweden } & \multirow{2}{*}{ CX } & HDG ISO1461 $(68 \mu \mathrm{m})$ & 9,9 & 15,6 & & & \\
\hline & & & & & & $\mathrm{Zn}(91 \%) / \mathrm{Mg}(6 \%) / \mathrm{Al}(3 \%)$ & 6,5 & 12,3 & & & \\
\hline & & \multirow{2}{*}{1.3} & \multirow{2}{*}{ Traffic tunnel } & \multirow{2}{*}{ Lundby - Sweden } & \multirow{2}{*}{ CX } & HDG ISO1461 $(68 \mu \mathrm{m})$ & 10,2 & 17 & & & \\
\hline & & & & & & $\mathrm{Zn}(91 \%) / \mathrm{Mg}(6 \%) / \mathrm{Al}(3 \%)$ & 7,4 & 13,3 & & & \\
\hline & & 1.4 & Traffic tunnel & Eugenia - Sweden & $\mathrm{c5}$ & $\mathrm{Zn}(91 \%) / \mathrm{Mg}(6 \%) / \mathrm{Al}(3 \%)$ & 4,8 & 9,2 & & & \\
\hline & & 15 & Troin tunnels & Örosund Surdon & $C_{2}$ & HDG ISO1461 $(68 \mu \mathrm{m})$ & 1,6 & 3 & & & \\
\hline & & 1.5 & Irain tunnels & Uresund - Sweden & $\mathrm{C} 3$ & $\mathrm{Zn}(91 \%) / \mathrm{Mg}(6 \%) / \mathrm{Al}(3 \%)$ & 1 & 1,8 & & & \\
\hline & & & & Strängnäs - & & HDG ISO1461 $(68 \mu \mathrm{m})$ & 1 & 1,6 & & & \\
\hline & & 1.6 & Train tunnels & Sweden & $\mathrm{C} 3$ & $\mathrm{Zn}(91 \%) / \mathrm{Mg}(6 \%) / \mathrm{Al}(3 \%)$ & 0,2 & 0,7 & & & \\
\hline & & 21 & Marine Onen nanels & Brect France & $C_{3}$ & PG $275 \mathrm{~g} / \mathrm{m}^{2}$ & 1,2 & & & & \\
\hline & & 2.1 & Marme - Upen paners & Brest - France & C3 & $\mathrm{Zn}-3,5 \% \mathrm{Al}-3 \% \mathrm{Mg}$ & 0,45 & & & & \\
\hline (Schouller- & 2 & 22 & Marine Onen nanels & Brest_France & $C 4$ & PG $275 \mathrm{~g} / \mathrm{m}^{2}$ & 2,2 & & & & \\
\hline & & 23 & Rural_-Onen nanels & Langonnet - & $C_{3}$ & PG $275 \mathrm{~g} / \mathrm{m}^{2}$ & 1,9 & & & & \\
\hline & & 2.5 & Kural - Open paners & France & C & $\mathrm{Zn}-(1-3) \% \mathrm{Al}-(1-3) \% \mathrm{Mg}$ & 0,9 & & & & \\
\hline & & & & & & PG $7 \mu \mathrm{m}$ & 1,78 & 1,95 & & & \\
\hline & & 3.1 & Marine - Open panels & Brest - France & $\mathrm{C} 4$ & $\mathrm{EZ} 7 \mu \mathrm{m}$ & 1,66 & 2,63 & & & \\
\hline & & & & & & $\mathrm{ZnMg} 1 \% \mathrm{Al1} \%$ & 1,21 & 1,62 & & & \\
\hline & & 3.2 & Marine - Open panels & Brest - France & $\mathrm{C} 4$ & $\mathrm{ZnMg} 1,5 \% \mathrm{Al1}, 5 \%$ & 0,87 & 1,14 & & & \\
\hline & & 3.3 & Marine - Open panels & Brest - France & $\mathrm{C} 4$ & $\mathrm{ZnMg} 2 \% \mathrm{Al} 2 \%$ & 0,86 & 1,28 & & & \\
\hline & & & & & & $\mathrm{PG} 7 \mu \mathrm{m}$ & 2,6 & 3,5 & & & \\
\hline & & 3.4 & Marine - Hem flanges & Brest - France & C5 & $\mathrm{EZ} 7 \mu \mathrm{m}$ & 5,8 & $>7$ & & & \\
\hline (Autocoat - & & & & & & $\mathrm{ZnMg} 1 \% \mathrm{Al1} \%$ & 2,2 & 4,2 & & & \\
\hline European & & 3.5 & Marine - Hem flanges & Brest - France & $\mathrm{C} 5$ & ZnMg1,5\%Al1,5\% & 4 & 2,3 & & & \\
\hline Comission, 2013; & 3 & 3.6 & Marine - Hem flanges & Brest - France & C5 & $\mathrm{ZnMg} 2 \% \mathrm{Al} 2 \%$ & 3,3 & 4 & & & \\
\hline LeBozec et al., & & & & & & PG $7 \mu \mathrm{m}$ & 0,75 & 1,63 & & & \\
\hline 2013) & & 3.7 & $\begin{array}{l}\text { Urban \& Industrial - Open } \\
\text { nanels }\end{array}$ & $\begin{array}{l}\text { Dormund - } \\
\text { Germany }\end{array}$ & $\mathrm{C} 3$ & $\mathrm{EZ} 7 \mu \mathrm{m}$ & 0,96 & 1,82 & & & \\
\hline & & & & & & $\mathrm{ZnMg} 1 \% \mathrm{Al} 1 \%$ & 0,5 & 1,2 & & & \\
\hline & & 3.8 & $\begin{array}{l}\text { Urban \& Industrial - Open } \\
\text { panels }\end{array}$ & $\begin{array}{l}\text { Dormund - } \\
\text { Germany }\end{array}$ & $\mathrm{C} 3$ & $\mathrm{ZnMg} 1,5 \% \mathrm{Al1}, 5 \%$ & 0,53 & 0,78 & & & \\
\hline & & & Urban \& Industrial - Hem & Dormund - & $\mathrm{C} 4$ & PG $7 \mu \mathrm{m}$ & 0,8 & 1,6 & & & \\
\hline & & 3.10 & flanges & Germany & $\mathrm{C} 4$ & $\mathrm{EZ} 7 \mu \mathrm{m}$ & 3,3 & 2,4 & & & \\
\hline
\end{tabular}




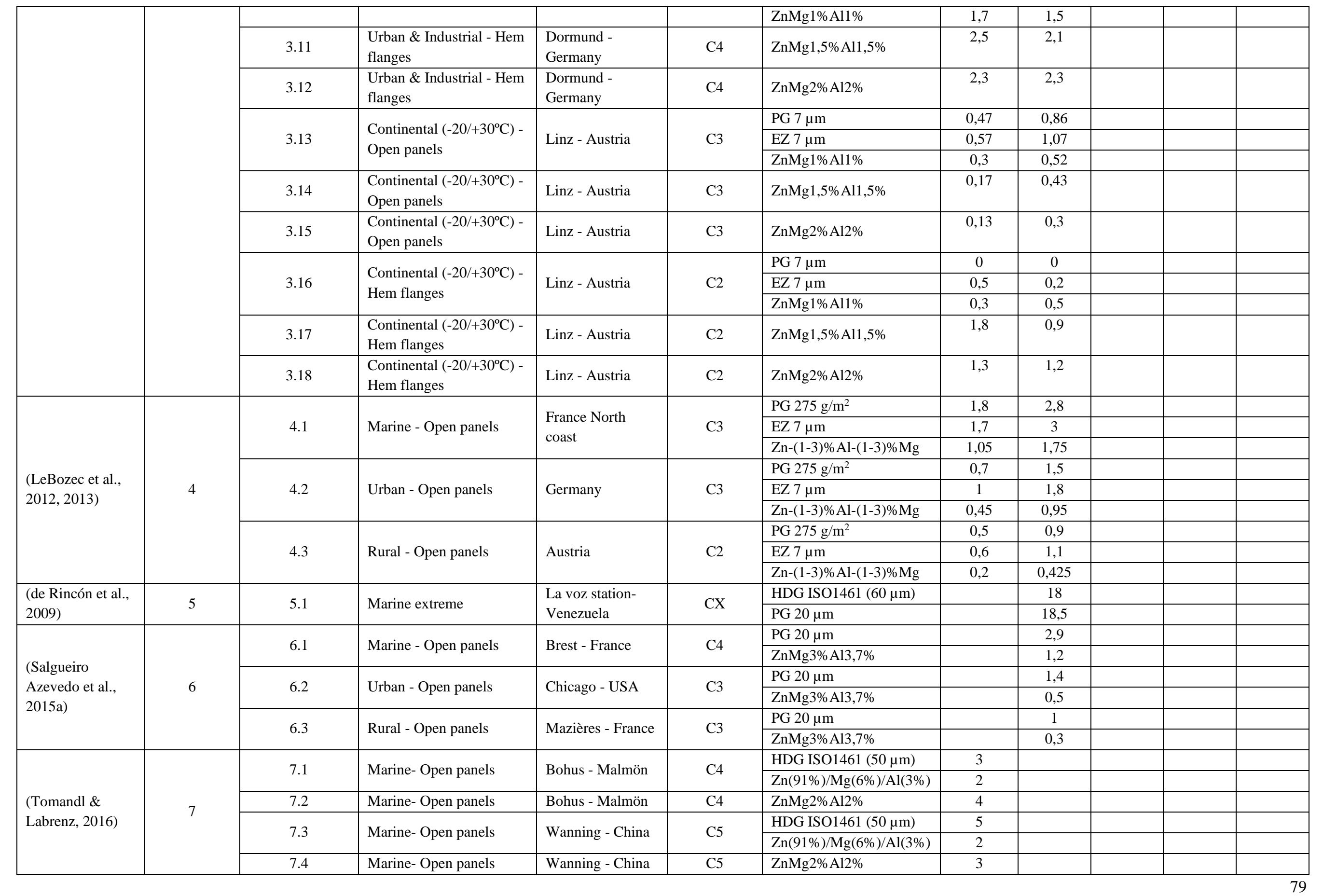




\begin{tabular}{|c|c|c|c|c|c|c|c|c|c|c|c|}
\hline & & \multirow{2}{*}{7.5} & \multirow{2}{*}{ Marine- Open panels } & \multirow{2}{*}{ Yucatán - México } & \multirow{2}{*}{$\mathrm{CX}$} & HDG ISO1461 $(50 \mu \mathrm{m})$ & 15 & & & & \\
\hline & & & & & & $\mathrm{Zn}(91 \%) / \mathrm{Mg}(6 \%) / \mathrm{Al}(3 \%)$ & 6 & & & & \\
\hline & & 7.6 & Marine- Open panels & Yucatán - México & $\mathrm{CX}$ & $\mathrm{ZnMg} 2 \% \mathrm{Al} 2 \%$ & 5 & & & & \\
\hline \multirow{28}{*}{$\begin{array}{l}\text { (Persson et al., } \\
\text { 2017; Dominique } \\
\text { Thierry, } \\
\text { LeBozec, et al., } \\
\text { 2019b; } \\
\text { Dominique } \\
\text { Thierry, Persson, } \\
\text { et al., 2019) }\end{array}$} & \multirow{28}{*}{8} & \multirow{2}{*}{8.1} & \multirow{2}{*}{ Marine } & \multirow{2}{*}{ Brest - France } & \multirow{2}{*}{$\mathrm{C} 3$} & PG $275 \mathrm{~g} / \mathrm{m}^{2}$ & 1,296 & 2,169 & & 4,620 & \\
\hline & & & & & & $\mathrm{ZnMg} 2 \% \mathrm{Al} 2 \%$ & 0,31 & 1,15 & & 2,35 & \\
\hline & & \multirow{2}{*}{8.2} & \multirow{2}{*}{ Marine } & \multirow{2}{*}{ Wanning - China } & \multirow{2}{*}{$\mathrm{C} 4$} & PG $275 \mathrm{~g} / \mathrm{m}^{2}$ & 2,803 & 4,690 & & 7,2394 & \\
\hline & & & & & & ZnMg2\%A12\% & 1,09 & 1,58 & & 4,15 & \\
\hline & & \multirow[b]{2}{*}{8.3} & \multirow[b]{2}{*}{ Marine } & \multirow[b]{2}{*}{$\begin{array}{l}\text { Daytona beach - } \\
\text { USA }\end{array}$} & \multirow{2}{*}{$\begin{array}{c}\mathrm{C} 4 \\
\text { (determined } \\
\text { in article) }\end{array}$} & PG $275 \mathrm{~g} / \mathrm{m}^{2}$ & 1,6197 & 4,0282 & & 4,3662 & \\
\hline & & & & & & $\mathrm{ZnMg} 2 \% \mathrm{~A} 12 \%$ & 0,38 & 1,03 & & 2,14 & \\
\hline & & \multirow{2}{*}{8.4} & \multirow{2}{*}{ Marine } & \multirow{2}{*}{$\begin{array}{l}\text { Sattaship } \\
\text { (Thailand) }\end{array}$} & \multirow{2}{*}{$\mathrm{C} 3$} & PG $275 \mathrm{~g} / \mathrm{m}^{2}$ & 0,9014 & 1,5211 & 1,9155 & & \\
\hline & & & & & & $\mathrm{ZnMg} 2 \% \mathrm{~A} 12 \%$ & 0,20 & 0,28 & 0,85 & & \\
\hline & & \multirow[b]{2}{*}{8.5} & \multirow[b]{2}{*}{ Marine } & \multirow{2}{*}{$\begin{array}{l}\text { Bohus - Malmön } \\
\text { (Kattesand) - } \\
\text { Sweden }\end{array}$} & & PG $275 \mathrm{~g} / \mathrm{m}^{2}$ & 1,6338 & 2,5775 & & 5,4507 & \\
\hline & & & & & $\mathrm{C} 3$ & $\mathrm{ZnMg} 2 \% \mathrm{Al} 2 \%$ & 0,62 & 0,91 & & 2,15 & \\
\hline & & & & Bohus - Malmön & $\mathrm{C} 5$ & PG $275 \mathrm{~g} / \mathrm{m}^{2}$ & 2,5634 & 5,1549 & & 7,8028 & \\
\hline & & 8.6 & Marine & $\begin{array}{l}\text { (Kvarnvik) - } \\
\text { Sweden }\end{array}$ & $\begin{array}{l}\text { (determined } \\
\text { in article) }\end{array}$ & $\mathrm{ZnMg} 2 \% \mathrm{Al} 2 \%$ & 1,11 & 1,32 & & 4,02 & \\
\hline & & & & Ijmuiden - The & & PG $275 \mathrm{~g} / \mathrm{m}^{2}$ & 1,0282 & 1,662 & & 3,4366 & \\
\hline & & 8.7 & Marine / Industrial & Netherlands & C3 & ZnMg2\%Al2\% & 0,34 & 1,05 & & 1,89 & \\
\hline & & & & & & PG $275 \mathrm{~g} / \mathrm{m}^{2}$ & 1,338 & 3,5493 & & 5,8169 & \\
\hline & & 8.8 & Marine / Industrial & Qingdao - China & C3 & $\mathrm{ZnMg} 2 \% \mathrm{Al} 2 \%$ & 0,71 & 1,74 & & 2,89 & \\
\hline & & & & & & PG $275 \mathrm{~g} / \mathrm{m}^{2}$ & 2,0282 & 3,5915 & & 6,0986 & \\
\hline & & 8.9 & Marine /Urban & Singapore & C3 & $\mathrm{ZnMg} 2 \% \mathrm{Al} 2 \%$ & 0,82 & 1,60 & & 3,38 & \\
\hline & & 810 & Marine / Utran & Dubai (Arabian & $\mathrm{C}_{4}$ & PG $275 \mathrm{~g} / \mathrm{m}^{2}$ & 2,1268 & 3,4507 & & 6,662 & \\
\hline & & 8.10 & Marine / Urban & United Emirates) & $\mathrm{C} 4$ & ZnMg2\%Al2\% & 0,52 & 1,58 & & 3,35 & \\
\hline & & & & & $\mathrm{C} 3$ & PG $275 \mathrm{~g} / \mathrm{m}^{2}$ & 0,6056 & 0,9155 & & 1,8028 & \\
\hline & & 8.11 & Marine / Urban & Cádiz - Spain & $\begin{array}{l}\text { (determined } \\
\text { in article) }\end{array}$ & $\mathrm{ZnMg} 2 \% \mathrm{~A} 12 \%$ & 0,28 & 0,43 & & 1,20 & \\
\hline & & & & & & PG $275 \mathrm{~g} / \mathrm{m}^{2}$ & 0,9296 & 1,662 & & & \\
\hline & & 8.12 & Industrial / Urban & $\begin{array}{l}\text { Ostrawa - Czech } \\
\text { Republic }\end{array}$ & $\mathrm{C} 3$ & $\mathrm{ZnMg} 2 \% \mathrm{Al} 2 \%$ & 0,46 & 0,78 & & $\begin{array}{r}\text { It doesn } \\
\mathrm{a}\end{array}$ & $\begin{array}{l}\text { ppear in } \\
\text { e }\end{array}$ \\
\hline & & 013 & Inductriol / Jubor & Bangkok - & $C_{2}$ & PG $275 \mathrm{~g} / \mathrm{m}^{2}$ & 0,507 & 1 & & 2,6761 & \\
\hline & & 8.13 & Industrial / Urban & Thailand & $\mathrm{C} 2$ & $\mathrm{ZnMg} 2 \% \mathrm{Al} 2 \%$ & 0,09 & 0,20 & & 0,92 & \\
\hline & & Q 14 & Inductriol / Jubor & Jipngiin Chin & $C_{3}$ & PG $275 \mathrm{~g} / \mathrm{m}^{2}$ & 1,2535 & 2,2535 & & 3,9859 & \\
\hline & & 8.14 & Industrial / Urban & Jiangjin - China & C3 & ZnMg2\%Al2\% & 0,65 & 1,49 & & 2,51 & \\
\hline (LeBozec et al., & & 01 & Marine & Brect France & $C_{3}$ & PG 20,7 $\mu \mathrm{m}$ & 0,9296 & 1,662 & & & \\
\hline 2019) & & 9.1 & Marıne & Brest - France & C3 & $\mathrm{ZnMg} 1,49 \% \mathrm{Al} 2,72 \%$ & 0,51 & 1,08 & & & \\
\hline (Dominique & 9 & 9.2 & Marine & Brest - France & $\mathrm{C} 3$ & $\mathrm{ZnMg} 1,51 \% \mathrm{Al} 2,71 \%$ & 0,34 & 0,68 & & & \\
\hline Thierry, & & 9.3 & Marine & Brest - France & C3 & $\mathrm{ZnMg} 1,51 \% \mathrm{Al} 2,67 \%$ & 0,65 & 0,85 & & & \\
\hline LeBozec, et al., & & 9.4 & Marine & Brest - France & $\mathrm{C} 3$ & $\mathrm{ZnMg} 1,6 \% \mathrm{Al} 2,9 \%$ & 0,54 & 0,71 & & & \\
\hline 2019b) & 10 & 10.1 & Marine & Brest - France & C3 & PG $275 \mathrm{~g} / \mathrm{m}^{2}$ & 1,296 & 2,169 & & 4,620 & 8,732 \\
\hline
\end{tabular}




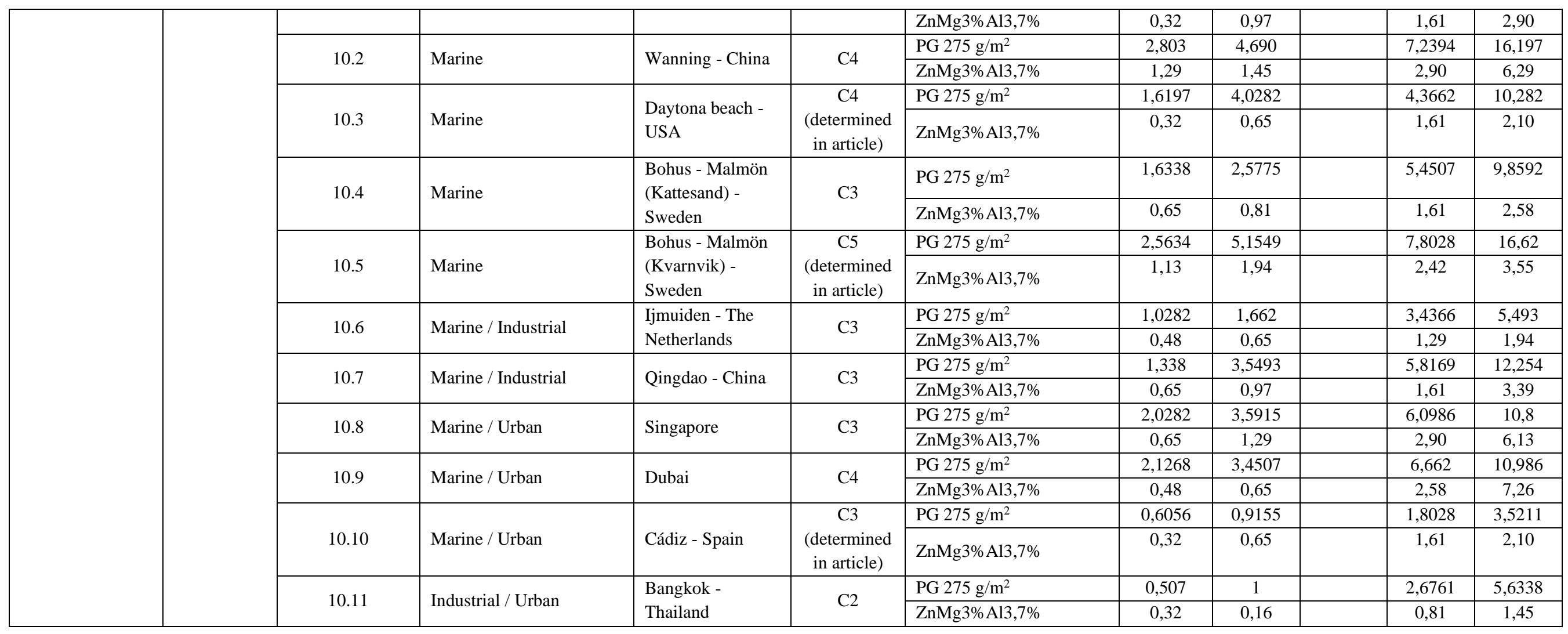




\subsubsection{ZM alloys}

Table 39 shows a summary of the results achieved in the background research for ZM alloys, where the corrosion rate is given in $\mu \mathrm{m} / \mathrm{year}$.

For a correct interpretation of the table, it is necessary to consider the following considerations:

- The corrosion rate values, have been classified by corrosivity category (C2, C3, C4, C5, CX), according to ISO 9223 (ISO, 2012).

- Corrosivity class according to ISO 9223, has been determined based in the corrosion rate for the first year of exposure of zinc finish, based on table 2 of said standard (see Table 11).

- In those tests for which there are no zinc finish tested, the corrosivity category designated by the authors has been used.

- Traceability with Table 38 is given through Test code file.

- No value has been found for $\mathrm{C} 1$ categories in any of the field tests.

- There are values up to 6 years of exposure, except for C5 and CX corrosivity categories, where only are values up to 2 years.

- $\quad$ C3 and C4 corrosivity categories have been those for which a greater number of measurements have been found.

Looking at Table 39, there are a series of inconsistencies or important remarks to do, that are highlighted in bold letter in the same table, and which are described below, by corrosivity category:

a) $\mathrm{C} 2$ corrosivity category

- Tests 3.16, 3.17 and 3.18 are tests done for hem flanges. This distorts the values of the series since, in hem flanges, the corrosion behaviour is very different that for flat treated surfaces. That's why these values should be removed from the table. As it was said at the beginning of this thesis, hem flanges and similar mechanical processes are not in the scope.

- The value of Test 10.11 for year 2 (from now on Y2) $(0,16 \mu \mathrm{m})$ is abnormally low, compared with the rest of the series, but it will be accepted anyway.

b) C3 corrosivity category

- The values of test 1.5 for $\mathrm{Y} 1(1 \mu \mathrm{m})$ and $\mathrm{Y} 2(1,8 \mu \mathrm{m})$ are abnormally high. This can be logical considering that corrosion rate for the first year of exposure for zinc $(1,6 \mu \mathrm{m})$, which is the criterion used to classify corrosivity categories as it was said before, is quite closed to the upper limit of $\mathrm{C} 3$ corrosivity class, according to ISO 9223 , which range is: $\left[0,7<\mathrm{r}_{\text {corr }} \leq 2,1\right]$ according to ISO 9223 .

- The values of tests 8.9 for Y4 $(3,38 \mu \mathrm{m})$ and 10.8 for Y6 $(6,13 \mu \mathrm{m})$, are abnormally high. In the same way that the previous dash, this can be logical considering that corrosion rate for the first year of exposure for zinc $(2,03 \mu \mathrm{m})$ is quite closed to the upper limit of $\mathrm{C} 3$ corrosivity class, according to ISO 9223 , which range is $\left[0,7<\mathrm{r}_{\text {corr }} \leq 2,1\right]$ i.e., closer to the $\mathrm{C} 4$ corrosivity category $\left[2,1<\mathrm{r}_{\text {corr }} \leq 4,2\right]$.

- The values of test 4.1 for Y1 $(1,05 \mu \mathrm{m})$ and Y2 $(1,75 \mu \mathrm{m})$ are abnormally high. Same explanation given before applies here, since the corrosion rate for the first year of exposure for zinc $(1,8 \mu \mathrm{m})$ is quite closed to the upper limit of $\mathrm{C} 3$ corrosivity class, according to ISO 9223 , which range is $\left[0,7<\mathrm{r}_{\text {corr }} \leq 2,1\right]$.

- The value of test 8.8 for Y2 $(1,74 \mu \mathrm{m})$ is abnormally high, with no reasonable explanation, so it will be kept in the table as it is, as part of the standard deviation.

- Tests 3.10, 3.11 and 3.12 are tests done for hem flanges. Thus, they will be discarded as it was explained before.

- The value of test 8.4 for $\mathrm{Y} 3(0,85 \mu \mathrm{m})$ is not consistent, because on one hand, it makes no sense that this value has the same value than the one in $\mathrm{C} 2$ for $\mathrm{Y} 4(0,86 \mu \mathrm{m})$ and on the other hand, it is very risky to take as valid, a value for one year within one specific corrosivity category with only one value.

- The value of test 10.8 for Y $6(6,13 \mu \mathrm{m})$ is very high in comparison with the average of the rest of the values, thus it will be discarded.

c) C4 corrosivity category

- The value of test 7.2 for Y1 $(4 \mu \mathrm{m})$ is abnormally high with no reasonable explanation, so it will be kept in the table as it is, as part of the standard deviation. 
- The value of test 8.2 for Y4 $(4,15 \mu \mathrm{m})$ is abnormally high with no reasonable explanation, so it will be kept in the table as it is, as part of the standard deviation.

- Tests 3.4, 3.5 and 3.6 are tests done for hem flanges. Thus, they will be discarded as it was explained before.

- The values of test 10.3 for Y1 $(0,32 \mu \mathrm{m})$ and for Y2 $(0,65 \mu \mathrm{m})$ are abnormally low. Corrosion rate of zinc for the first year of exposure in these tests is $1,62 \mu \mathrm{m}$, which is in the range of $\mathrm{C} 3$ corrosivity category $\left[0,7<\mathrm{r}_{\text {corr }} \leq 2,1\right]$ instead $\mathrm{C} 4\left[2,1<\mathrm{r}_{\text {corr }} \leq 4,2\right]$, according to ISO 9223. But the authors have declared the corrosivity category as $\mathrm{C} 4$. Thus, the results of these tests will be moved to $\mathrm{C} 3$ corrosivity category so to have the correct consistency.

- The values of test 10.9 for Y1 $(0,48 \mu \mathrm{m})$ and for Y2 $(0,65 \mu \mathrm{m})$ are abnormally low. Corrosion rate of zinc for the first year of exposure in this test is $2,13 \mu \mathrm{m}$, which is slightly above the lower limit of $\mathrm{C} 4$ corrosivity category $\left[2,1<\mathrm{r}_{\text {corr }} \leq 4,2\right]$, according to ISO 9223 . So, the value will be kept in C4, but this way it justifies this lower value.

d) C5 corrosivity category

- The values of test 8.6 for Y1 $(1,11 \mu \mathrm{m})$, for Y2 $(1,32 \mu \mathrm{m})$ and for Y4 $(4,02 \mu \mathrm{m})$ are abnormally low. Corrosion rate of zinc for the first year of exposure in these tests is $2,56 \mu \mathrm{m}$, which is in the range of $\mathrm{C} 4$ corrosivity category $\left[2,1<\mathrm{r}_{\text {corr }} \leq 4,2\right]$ instead $\mathrm{C} 5\left[4,2<\mathrm{r}_{\text {corr }} \leq 8,4\right]$, according to ISO 9223 . But the authors have declared the corrosivity category as $\mathrm{C} 5$. Thus, the results of these tests will be moved to $\mathrm{C} 4$ corrosivity category so to have the correct consistency.

- In the same way, the values of test 10.5 for Y1 $(1,13 \mu \mathrm{m})$, for Y2 $(1,94 \mu \mathrm{m})$, for Y4 $(2,42 \mu \mathrm{m})$ and for Y6 $(3,55 \mu \mathrm{m})$ are abnormally low. Corrosion rate of zinc for the first year of exposure in these tests is $2,56 \mu \mathrm{m}$, which is in the range of $\mathrm{C} 4$ corrosivity category $\left[2,1<\mathrm{r}_{\text {corr }} \leq 4,2\right]$ instead $\mathrm{C} 5\left[4,2<\mathrm{r}_{\text {corr }} \leq 8,4\right]$, according to ISO 9223. But the authors have declared the corrosivity category as $\mathrm{C} 5$. Thus, the results of these tests will be moved to $\mathrm{C} 4$ corrosivity category so to have the correct consistency.

Table 40 is a review of Table 39 considering all the inconsistencies described before. Table 41 shows for each corrosivity category, the values of the mean, the median and the standard deviation after this revision.

These tables will be the ones that will be used for the subsequent analysis. 
Table 39: Summary of corrosion rate results ( $\mu \mathrm{m} / \mathrm{year}$ ) for ZM finishes

\begin{tabular}{|c|c|c|c|c|c|c|c|c|c|c|c|c|c|c|c|c|c|c|c|c|c|c|c|c|c|c|c|c|c|c|c|c|c|c|c|c|c|c|}
\hline \multirow{2}{*}{$\begin{array}{c}\text { Corrosivity } \\
\text { category ISO } 9223\end{array}$} & \multirow{2}{*}{ Year } & \multicolumn{37}{|c|}{ Field test } \\
\hline & & 1 & 2 & 3 & 4 & 5 & 6 & 7 & 8 & 9 & 10 & 11 & 12 & 13 & 14 & 15 & 16 & 17 & 18 & 19 & 20 & 21 & 22 & 23 & 24 & 25 & 26 & 27 & 28 & 29 & 30 & 31 & 32 & 33 & 34 & 35 & 36 & 37 \\
\hline \multirow{5}{*}{ C2 - Low } & Year 1 & 0,30 & 0,17 & 0,13 & 0,30 & 1,80 & 1,30 & 0,20 & 0,09 & 0,32 & & & & & & & & & & & & & & & & & & & & & & & & & & & & \\
\hline & Year 2 & 0,52 & 0,43 & 0,30 & 0,50 & 0,90 & 1,20 & 0,43 & 0,20 & 0,16 & & & & & & & & & & & & & & & & & & & & & & & & & & & & \\
\hline & Year 4 & & & & & & & & 0,92 & 0,81 & & & & & & & & & & & & & & & & & & & & & & & & & & & & \\
\hline & Year 6 & & & & & & & & & 1,45 & & & & & & & & & & & & & & & & & & & & & & & & & & & & \\
\hline & Test code & 3.13 & 3.14 & 3.15 & 3.16 & 3.17 & 3.18 & 4.3 & 8.13 & 10.11 & & & & & & & & & & & & & & & & & & & & & & & & & & & & \\
\hline \multirow{5}{*}{ C3 - Medium } & Year 1 & \begin{tabular}{|l}
0,70 \\
\end{tabular} & 1,00 & 0,20 & 0,45 & 0,90 & 1,21 & 0,87 & 0,86 & 0,50 & 0,53 & 0,36 & 1,70 & 2,50 & 2,30 & 1,05 & 0,45 & & & 0,31 & 0,20 & 0,62 & 0,34 & 0,71 & 0,82 & 0,28 & 0,46 & 0,65 & 0,51 & 0,34 & 0,65 & 0,54 & 0,32 & 0,65 & 0,48 & 0,65 & 0,65 & 0,32 \\
\hline & $\begin{array}{l}\text { Year } 2 \\
\text { Year } 3\end{array}$ & 1,30 & 1,80 & 0,70 & & & 1,62 & 1,14 & 1,28 & 1,20 & 0,78 & 0,79 & 1,50 & 2,10 & 2,30 & 1,75 & 0,95 & 0,50 & 0,30 & 1,15 & $\begin{array}{l}0,28 \\
0,85\end{array}$ & 0,91 & 1,05 & 1,74 & 1,60 & 0,43 & 0,78 & 1,49 & 1,08 & 0,68 & 0,85 & 0,71 & 0,97 & 0,81 & 0,65 & 0,97 & 1,29 & 0,65 \\
\hline & Year 4 & & & & & & & & & & & & & & & & & & & 2,35 & & 2,15 & 1,89 & 2,89 & 3,38 & 1,20 & & 2,51 & & & & & 1,61 & 1,61 & 1,29 & 1,61 & 2,90 & 1,29 \\
\hline & Year 6 & & & & & & & & & & & & & & & & & & & & & & & & & & & & & & & & 2,90 & 2,58 & 1,94 & 3,39 & 6,13 & 32,10 \\
\hline & Test code & \begin{tabular}{|l|}
1.1 \\
\end{tabular} & 1.5 & 1.6 & 2.1 & 2.3 & 3.1 & 3.2 & 3.3 & 3.7 & 3.8 & 3.9 & 3.10 & 3.11 & 3.12 & 4.1 & 4.2 & 6.2 & 6.3 & 8.1 & 8.4 & 8.5 & 8.7 & 8.8 & 8.9 & 8.11 & 8.12 & 8.14 & 9.1 & 9.2 & 9.3 & 9.4 & 10.1 & 10.4 & 10.6 & 10.7 & 10.8 & 310.10 \\
\hline \multirow{5}{*}{ C4 - High } & Year 1 & 1,00 & 2,20 & 4,00 & 3,30 & & 2,00 & 4,00 & 1,09 & 0,38 & 0,52 & 1,29 & 0,32 & 0,48 & & & & & & & & & & & & & & & & & & & & & & & & \\
\hline & Year 2 & - & 4,20 & 2,30 & 4,00 & 1,20 & & & 1,58 & 1,03 & 1,58 & 1,45 & 0,65 & 0,65 & & & & & & & & & & & & & & & & & & & & & & & & \\
\hline & Year 4 & & & & & & & & 4,15 & 2,14 & 3,35 & 2,90 & 1,61 & 2,58 & & & & & & & & & & & & & & & & & & & & & & & & \\
\hline & Year 6 & & & & & & & & & & & 6,29 & 2,10 & 7,26 & & & & & & & & & & & & & & & & & & & & & & & & \\
\hline & Test code & 2.2 & 3.4 & 3.5 & 3.6 & 6.1 & 7.1 & 7.2 & 8.2 & 8.3 & 8.10 & 10.2 & 10.3 & 10.9 & & & & & & & & & & & & & & & & & & & & & & & & \\
\hline \multirow{5}{*}{ C5 - Vey high } & Year 1 & 4,80 & 2,00 & 3,00 & 1,11 & 1,13 & & & & & & & & & & & & & & & & & & & & & & & & & & & & & & & & \\
\hline & Year 2 & 9,20 & & & 1,32 & 1,94 & & & & & & & & & & & & & & & & & & & & & & & & & & & & & & & & \\
\hline & Year 4 & & & & 4,02 & 2,42 & & & & & & & & & & & & & & & & & & & & & & & & & & & & & & & & \\
\hline & Year 6 & & & & & 3,55 & & & & & & & & & & & & & & & & & & & & & & & & & & & & & & & & \\
\hline & Test code & \begin{tabular}{|l|}
1.4 \\
\end{tabular} & 7.3 & 7.4 & 8.6 & 10.5 & & & & & & & & & & & & & & & & & & & & & & & & & & & & & & & & \\
\hline \multirow{2}{*}{ CX - Extreme } & \begin{tabular}{|l|} 
Year 1 \\
Year 2
\end{tabular} & $\begin{array}{r}6,50 \\
12,30\end{array}$ & $\begin{array}{r}7,40 \\
13,30\end{array}$ & 6,00 & 5,00 & & & & & & & & & & & & & & & & & & & & & & & & & & & & & & & & & \\
\hline & \begin{tabular}{|l|} 
Year 2 \\
Test code \\
\end{tabular} & \begin{tabular}{|l|}
12,30 \\
1.2
\end{tabular} & $\begin{array}{c}\frac{13,30}{1.3} \\
\end{array}$ & 7.5 & 7.6 & & & & & & & & & & & & & & & & & & & & & & & & & & & & & & & & & \\
\hline
\end{tabular}


Table 40: Reviewed summary of corrosion rate results ( $\mu \mathrm{m} / \mathrm{year})$ for ZM finishes

\begin{tabular}{|c|c|c|c|c|c|c|c|c|c|c|c|c|c|c|c|c|c|c|c|c|c|c|c|c|c|c|c|c|c|c|c|c|c|c|c|c|}
\hline \multirow{2}{*}{$\begin{array}{c}\text { Corrosivity } \\
\text { category ISO } 9223 \\
\end{array}$} & \multirow{2}{*}{ Year } & \multicolumn{35}{|c|}{ Field test } \\
\hline & & 1 & 2 & 3 & 4 & 5 & 6 & 7 & 8 & 9 & 10 & 11 & 12 & 13 & 14 & 15 & 16 & 17 & 18 & 19 & 20 & 21 & 22 & 23 & 24 & 25 & 26 & 27 & 28 & 29 & 30 & 31 & 32 & 33 & 34 & 35 \\
\hline \multirow{5}{*}{ C2 - Low } & Year 1 & 0,30 & 0,17 & 0,13 & 0,20 & 0,09 & 0,32 & & & & & & & & & & & & & & & & & & & & & & & & & & & & & \\
\hline & Year 2 & 0,52 & 0,43 & 0,30 & 0,43 & 0,20 & 0,16 & & & & & & & & & & & & & & & & & & & & & & & & & & & & & \\
\hline & Year 4 & & & & & 0,92 & 0,81 & & & & & & & & & & & & & & & & & & & & & & & & & & & & & \\
\hline & Year 6 & & & & & & 1,45 & & & & & & & & & & & & & & & & & & & & & & & & & & & & & \\
\hline & \begin{tabular}{|l|} 
Test code \\
\end{tabular} & 3.13 & 3.14 & 3.15 & 4.3 & 8.13 & 10.11 & & & & & & & & & & & & & & & & & & & & & & & & & & & & & \\
\hline \multirow{5}{*}{ C3 - Medium } & Year 1 & \begin{tabular}{|l|}
0,70 \\
\end{tabular} & 1,00 & 0,20 & 0,45 & 0,90 & 1,21 & 0,87 & 0,86 & 0,50 & 0,53 & 0,36 & 1,05 & 0,45 & & & 0,31 & 0,20 & 0,62 & 0,34 & 0,71 & 0,82 & 0,28 & 0,46 & 0,65 & 0,51 & 0,34 & 0,65 & 0,54 & 0,32 & 0,32 & 0,65 & 0,48 & 0,65 & 0,65 & 0,32 \\
\hline & Year 2 & 1,30 & 1,80 & 0,70 & & & 1,62 & 1,14 & 1,28 & 1,20 & 0,78 & 0,79 & 1,75 & 0,95 & 0,50 & 0,30 & 1,15 & 0,28 & 0,91 & 1,05 & 1,74 & 1,60 & 0,43 & 0,78 & 1,49 & 1,08 & 0,68 & 0,85 & 0,71 & 0,97 & 0,65 & 0,81 & 0,65 & 0,97 & 1,29 & 0,65 \\
\hline & Year 4 & & & & & & & & & & & & & & & & 2,35 & & 2,15 & 1,89 & 2,89 & 3,38 & 1,20 & & 2,51 & & & & & 1,61 & 1,61 & 1,61 & 1,29 & 1,61 & 2,90 & 1,29 \\
\hline & Year 6 & & & & & & & & & & & & & & & & & & & & & & & & & & & & & 2,90 & 2,10 & 2,58 & 1,94 & 3,39 & & 2,10 \\
\hline & Test code & 1.1 & 1.5 & 1.6 & 2.1 & 2.3 & 3.1 & 3.2 & 3.3 & 3.7 & 3.8 & 3.9 & 4.1 & 4.2 & 6.2 & 6.3 & 8.1 & 8.4 & 8.5 & 8.7 & 8.8 & 8.9 & 8.118 & 8.12 & 8.14 & 9.1 & 9.2 & 9.3 & 9.4 & 10.1 & 10.3 & 10.4 & 10.6 & 10.7 & & 10.10 \\
\hline \multirow{5}{*}{ C4 - High } & Year 1 & 1,00 & & 2,00 & 1,09 & 0,38 & 1,11 & 0,52 & 1,29 & 1,13 & 0,48 & & & & & & & & & & & & & & & & & & & & & & & & & \\
\hline & Year 2 & & 1,20 & & 1,58 & 1,03 & 1,32 & 1,58 & 1,45 & 1,94 & 0,65 & & & & & & & & & & & & & & & & & & & & & & & & & \\
\hline & Year 4 & & & & 4,15 & 2,14 & 4,02 & 3,35 & 2,90 & 2,42 & 2,58 & & & & & & & & & & & & & & & & & & & & & & & & & \\
\hline & Year 6 & & & & & & & & 6,29 & 3,55 & 7,26 & & & & & & & & & & & & & & & & & & & & & & & & & \\
\hline & Test code & 2.2 & 6.1 & 7.1 & 8.2 & 8.3 & 8.6 & 8.10 & 10.2 & 10.5 & 10.9 & & & & & & & & & & & & & & & & & & & & & & & & & \\
\hline \multirow{3}{*}{ C5 - Vey high } & Year 1 & 4,80 & 2,00 & 3,00 & & & & & & & & & & & & & & & & & & & & & & & & & & & & & & & & \\
\hline & Year 2 & 9,20 & & & & & & & & & & & & & & & & & & & & & & & & & & & & & & & & & & \\
\hline & \begin{tabular}{|l|} 
Test code \\
\end{tabular} & 1.4 & 7.3 & 7.4 & & & & & & & & & & & & & & & & & & & & & & & & & & & & & & & & \\
\hline \multirow{3}{*}{ CX - Extreme } & Year 1 & 6,50 & 7,40 & 6,00 & 5,00 & & & & & & & & & & & & & & & & & & & & & & & & & & & & & & & \\
\hline & Year 2 & 12,30 & 13,30 & & & & & & & & & & & & & & & & & & & & & & & & & & & & & & & & & \\
\hline & Test code & \begin{tabular}{|l|}
1.2 \\
\end{tabular} & 1.3 & 7.5 & 7.6 & & & & & & & & & & & & & & & & & & & & & & & & & & & & & & & \\
\hline
\end{tabular}


Table 41: Average, median and standard deviation from field tests for ZM finishes

\begin{tabular}{lllll}
$\begin{array}{c}\text { Corrosivity category } \\
\text { ISO 9223 }\end{array}$ & Year & Average & Median & \multicolumn{1}{c}{$\begin{array}{c}\text { Standard } \\
\text { deviation }\end{array}$} \\
& Year 1 & 0,20 & 0,19 & 0,23 \\
C2 - Low & Year 2 & 0,34 & 0,36 & 0,14 \\
& Year 4 & 0,86 & 0,86 & 0,08 \\
& Year 6 & 1,45 & 1,45 & - \\
\hline \multirow{3}{*}{ C3 - Medium } & Year 1 & 0,57 & 0,53 & 0,25 \\
& Year 2 & 0,99 & 0,95 & 0,42 \\
& Year 4 & 2,07 & 1,91 & 0,66 \\
& Year 6 & 2,50 & 2,34 & 0,57 \\
\hline \multirow{3}{*}{ C4 - High } & Year 1 & 1,00 & 1,09 & 0,47 \\
& Year 2 & 1,34 & 1,39 & 0,37 \\
& Year 4 & 3,08 & 2,90 & 0,73 \\
C5 - Vey high & Year 6 & 5,70 & 6,29 & 1,57 \\
\hline \multirow{2}{*}{ CX - Extreme } & Year 1 & 3,27 & 3,00 & 1,42 \\
& Year 2 & 9,20 & 9,20 & - \\
\hline \multirow{2}{*}{ Year 1 } & 6,23 & 6,25 & 1,00 \\
& Year 2 & 12,80 & 12,80 & 0,71 \\
\hline
\end{tabular}

\subsubsection{Zinc coatings}

Table 42 shows a summary of the results achieved in the background research for zinc-based coatings ( $\mathrm{Z}$ coatings from now on), where the corrosion rate is given in $\mu \mathrm{m} /$ year. It is important to consider that these tests are the same done for ZM alloys described before, to be able to compare in the same conditions, the behaviour of both type of coatings.

For a correct interpretation of the table, it is necessary to consider the following considerations:

- The corrosion rate values, have been classified by corrosivity category $(\mathrm{C} 2, \mathrm{C} 3, \mathrm{C} 4, \mathrm{C} 5, \mathrm{CX})$, according to ISO 9223 (ISO, 2012).

- Corrosivity class according to ISO 9223, has been determined based in the corrosion rate for the first year of exposure of zinc finish, based on table 2 of said standard (see Table 11).

- In those tests for which there were no zinc finish tested, the corrosivity category designated by the authors has been used.

- $\quad$ Traceability with Table 38 is given through Test code file.

- $\quad$ No value has been found for $\mathrm{C} 1$ categories in any of the field tests.

- There are values up to 6 years of exposure, except for CX corrosivity category, where only are values up to 2 years.

- $\quad$ C3 and C4 corrosivity categories have been those for which a greater number of measurements have been found.

Looking at Table 42, there are a series of inconsistencies or important remarks to do, that are highlighted in bold letter in the same table and which are described below, by corrosivity category:

a) C2 corrosivity category

- Test 3.16 is a test done for hem flanges. It distorts the values of the series since, in hem flanges, the corrosion behaviour is very different that for flat treated surfaces. That's why these values should be removed from the table. As it was said at the beginning of this thesis, hem flanges and similar mechanical processes are not in the scope. 
b) C3 corrosivity category

- Tests 3.10 is a test done for hem flanges. Thus, they will be discarded as it was explained before

- The value of test 6.3 for Y2 $(1,00 \mu \mathrm{m})$ is abnormally low. Corrosion rate of zinc for the first year of exposure is not given in this test, but looking at the second-year value $(1 \mu \mathrm{m})$, for the first year should be slightly lower, i.e. it should be in the range of $\mathrm{C} 2$ corrosivity category $\left[0,1<\mathrm{r}_{\text {corr }} \leq 0,7\right]$ instead $\mathrm{C} 3[0,7<$ $\left.\mathrm{r}_{\text {corr }} \leq 2,1\right]$, according to ISO 9223 . But the authors have declared the corrosivity category as C3. Thus, the result of this test will be moved to $\mathrm{C} 2$ corrosivity category so to have the correct consistency.

- The values of test 10.10 for Y1 $(0,61 \mu \mathrm{m})$, for Y2 $(0,92 \mu \mathrm{m})$, for Y4 $(1,80 \mu \mathrm{m})$ and for Y6 $(3,52 \mu \mathrm{m})$ are abnormally low. Corrosion rate of zinc for the first year of exposure in these tests is $0,61 \mu \mathrm{m}$, which is in the range of $\mathrm{C} 2$ corrosivity category $\left[0,1<\mathrm{r}_{\text {corr }} \leq 0,7\right]$ instead $\mathrm{C} 3\left[0,7<\mathrm{r}_{\text {corr }} \leq 2,1\right]$, according to ISO 9223 . But the authors have declared the corrosivity category as $\mathrm{C} 3$. Thus, the results of these tests will be moved to $\mathrm{C} 2$ corrosivity category so to have the correct consistency.

- The value of test 8.4 for Y3 $(1,92 \mu \mathrm{m})$ is not consistent, because on one hand, it makes no sense that this value is less than the average of Y2 $(2,24 \mu \mathrm{m})$ (see Table 44) and on the other hand, it is very risky to take as valid, a value for one year within one specific corrosivity category with only one value.

c) C4 corrosivity category

- Tests 3.4 is a test done for hem flanges. Thus, they will be discarded as it was explained before.

- The value of test 10.10 for Y1 $(1,62 \mu \mathrm{m})$ is abnormally low. Corrosion rate of zinc for the first year of exposure in these tests is $1,62 \mu \mathrm{m}$, which is in the range of $\mathrm{C} 3$ corrosivity category $\left[0,7<\mathrm{r}_{\text {corr }} \leq 2,1\right]$ instead C4 $\left[2,1<\mathrm{r}_{\text {corr }} \leq 4,2\right]$, according to ISO 9223 . But the authors have declared the corrosivity category as C4. Thus, the results of these tests will be moved to C3 corrosivity category so to have the correct consistency.

d) C5 corrosivity category

- The value of test 10.5 for Y1 $(2,56 \mu \mathrm{m})$ and for Y2 $(5,15 \mu \mathrm{m})$ are abnormally low. Corrosion rate of zinc for the first year of exposure in these tests is $2,56 \mu \mathrm{m}$, which is in the range of $\mathrm{C} 4$ corrosivity category $\left[2,1<\mathrm{r}_{\text {corr }} \leq 4,2\right]$ instead C5 $\left[4,2<\mathrm{r}_{\text {corr }} \leq 8,4\right]$, according to ISO 9223. But the authors have declared the corrosivity category as $\mathrm{C} 5$. Thus, the results of these tests will be moved to $\mathrm{C} 4$ corrosivity category so to have the correct consistency.

Table 43 is a review of Table 42 considering all the inconsistencies described before. Table 44 shows for each corrosivity category, the values of the mean, the median and the standard deviation after this revision.

These tables will be the ones that will be used for the subsequent analysis. 
Table 42: Summary of corrosion rate results ( $\mu \mathrm{m} / \mathrm{year}$ ) for $\mathrm{Z}$ finishes

\begin{tabular}{|c|c|c|c|c|c|c|c|c|c|c|c|c|c|c|c|c|c|c|c|c|c|c|c|c|c|c|c|}
\hline \multirow{2}{*}{$\begin{array}{c}\text { Corrosivity } \\
\text { category ISO } 9223\end{array}$} & \multirow{2}{*}{ Year } & \multicolumn{26}{|c|}{ Field test } \\
\hline & & 1 & 2 & 3 & 4 & 5 & 6 & 7 & 8 & 9 & 10 & 11 & 12 & 13 & 14 & 15 & 16 & 17 & 18 & 19 & 20 & 21 & 22 & 23 & 24 & 25 & 26 \\
\hline \multirow{5}{*}{ C2 - Low } & Year 1 & 0,47 & 0,57 & 0,50 & 0,50 & 0,60 & 0,51 & & & & & & & & & & & & & & & & & & & & \\
\hline & Year 2 & 0,86 & 1,07 & 0,70 & 0,90 & 1,10 & 1,00 & & & & & & & & & & & & & & & & & & & & \\
\hline & Year 4 & & & & & & 2,68 & & & & & & & & & & & & & & & & & & & & \\
\hline & Year 6 & & & & & & 5,63 & & & & & & & & & & & & & & & & & & & & \\
\hline & Test code & 3.13 & 3.13 & 3.16 & 4.3 & 4.3 & 10.11 & & & & & & & & & & & & & & & & & & & & \\
\hline \multirow{6}{*}{ C3 - Medium } & Year 1 & 1,60 & 1,60 & 1,00 & 1,20 & 1,90 & 1,78 & 1,66 & 0,75 & 0,96 & 0,80 & 3,30 & 1,80 & 1,70 & 0,70 & 1,00 & - & - & 0,90 & 1,25 & 0,93 & 1,30 & 1,63 & 1,03 & 1,34 & 2,03 & 30,61 \\
\hline & Year 2 & 2,80 & 3,00 & 1,60 & & & 1,95 & 2,63 & 1,63 & 1,82 & 2,40 & 5,70 & 2,80 & 3,00 & 1,50 & 1,80 & 1,40 & 1,00 & 1,52 & 2,25 & 1,66 & 2,17 & 2,58 & 1,66 & 3,55 & 3,59 & 90,92 \\
\hline & Year 3 & & & & & & & & & & & & & & & & & & 1,92 & & & & & & & & \\
\hline & Year 4 & & & & & & & & & & & & & & & & & & & 3,99 & & 4,62 & 5,45 & 3,44 & 5,82 & 6,10 & D 1,80 \\
\hline & Year 6 & & & & & & & & & & & & & & & & & & & & & 8,73 & 9,86 & 5,49 & 12,25 & 10,80 & 3,52 \\
\hline & Test code & 1.1 & 1.5 & 1.6 & 2.1 & 2.3 & 3.1 & 3.1 & 3.7 & 3.7 & 3.10 & 3.10 & 4.1 & 4.1 & 4.2 & 4.2 & 6.2 & 6.3 & 8.4 & 8.14 & 9.1 & 10.1 & 10.4 & 10.6 & 10.7 & 10.8 & 10.10 \\
\hline \multirow{5}{*}{ C4 - High } & Year 1 & 2,20 & 2,60 & 5,80 & - & 3,00 & 2,80 & 1,62 & 2,13 & & & & & & & & & & & & & & & & & & \\
\hline & Year 2 & & 3,50 & & 2,90 & & 4,69 & 4,03 & 3,45 & & & & & & & & & & & & & & & & & & \\
\hline & Year 4 & & & & & & 7,24 & 4,37 & 6,66 & & & & & & & & & & & & & & & & & & \\
\hline & Year 6 & & & & & & 16,20 & 10,28 & 10,99 & & & & & & & & & & & & & & & & & & \\
\hline & Test code & 2.2 & 3.4 & 3.4 & 6.1 & 7.1 & 10.2 & 10.3 & 10.9 & & & & & & & & & & & & & & & & & & \\
\hline \multirow{5}{*}{ C5 - Vey high } & Year 1 & 6,60 & 5,00 & 2,56 & & & & & & & & & & & & & & & & & & & & & & & \\
\hline & Year 2 & 11 & & 5,15 & & & & & & & & & & & & & & & & & & & & & & & \\
\hline & Year 4 & & & 7,80 & & & & & & & & & & & & & & & & & & & & & & & \\
\hline & Year 6 & & & 16,62 & & & & & & & & & & & & & & & & & & & & & & & \\
\hline & Test code & 1.4 & 7.3 & 10.5 & & & & & & & & & & & & & & & & & & & & & & & \\
\hline \multirow{3}{*}{ CX - Extreme } & Year 1 & 9,90 & 10,20 & - & - & 15 & & & & & & & & & & & & & & & & & & & & & \\
\hline & Year 2 & 15,60 & 17,00 & 18,00 & 18,50 & & & & & & & & & & & & & & & & & & & & & & \\
\hline & Test code & 1.2 & 1.3 & 5.1 & 5.1 & 7.5 & & & & & & & & & & & & & & & & & & & & & \\
\hline
\end{tabular}


Table 43: Reviewed summary of corrosion rate results ( $\mu \mathrm{m} / \mathrm{year}$ ) for $\mathrm{Z}$ finishes

\begin{tabular}{|c|c|c|c|c|c|c|c|c|c|c|c|c|c|c|c|c|c|c|c|c|c|c|c|c|}
\hline \multirow{2}{*}{$\begin{array}{c}\text { Corrosivity } \\
\text { category ISO } 9223\end{array}$} & \multirow{2}{*}{ Year } & \multicolumn{23}{|c|}{ Field test } \\
\hline & & 1 & 2 & 3 & 4 & 5 & 6 & 7 & 8 & 9 & 10 & 11 & 12 & 13 & 14 & 15 & 16 & 17 & 18 & 19 & 20 & 21 & 22 & 23 \\
\hline \multirow{5}{*}{ C2 - Low } & Year 1 & 0,47 & 0,57 & 0,50 & 0,60 & & 0,61 & 0,51 & & & & & & & & & & & & & & & & \\
\hline & Year 2 & 0,86 & 1,07 & 0,90 & 1,10 & 1,00 & 0,92 & 1,00 & & & & & & & & & & & & & & & & \\
\hline & Year 4 & & & & & & 1,80 & 2,68 & & & & & & & & & & & & & & & & \\
\hline & Year 6 & & & & & & 3,52 & 5,63 & & & & & & & & & & & & & & & & \\
\hline & Test code & 3.13 & 3.13 & 4.3 & 4.3 & 6.3 & 10.10 & 10.11 & & & & & & & & & & & & & & & & \\
\hline \multirow{5}{*}{ C3 - Medium } & Year 1 & 1,60 & 1,60 & 1,00 & 1,20 & 1,90 & 1,78 & 1,66 & 0,75 & 0,96 & 1,80 & 1,70 & 0,70 & 1,00 & & 0,90 & 1,25 & 0,93 & 1,30 & 1,62 & 1,63 & 1,03 & 1,34 & 2,03 \\
\hline & Year 2 & 2,80 & 3,00 & 1,60 & & & 1,95 & 2,63 & 1,63 & 1,82 & 2,80 & 3,00 & 1,50 & 1,80 & 1,40 & 1,52 & 2,25 & 1,66 & 2,17 & 4,03 & 2,58 & 1,66 & 3,55 & 3,59 \\
\hline & Year 4 & & & & & & & & & & & & & & & & 3,99 & & 4,62 & 4,37 & 5,45 & 3,44 & 5,82 & 6,10 \\
\hline & Year 6 & & & & & & & & & & & & & & & & & & 8,73 & 10,28 & 9,86 & 5,49 & 12,25 & 10,80 \\
\hline & Test code & 1.1 & 1.5 & 1.6 & 2.1 & 2.3 & 3.1 & 3.1 & 3.7 & 3.7 & 4.1 & 4.1 & 4.2 & 4.2 & 6.2 & 8.4 & 8.14 & 9.1 & 10.1 & 10.3 & 10.4 & 10.6 & 10.7 & 10.8 \\
\hline \multirow{5}{*}{ C4 - High } & Year 1 & 2,20 & & 3,00 & 2,80 & 2,56 & 2,13 & & & & & & & & & & & & & & & & & \\
\hline & Year 2 & & 2,90 & & 4,69 & 5,15 & 3,45 & & & & & & & & & & & & & & & & & \\
\hline & Year 4 & & & & 7,24 & 7,80 & 6,66 & & & & & & & & & & & & & & & & & \\
\hline & Year 6 & & & & 16,20 & 16,62 & 10,99 & & & & & & & & & & & & & & & & & \\
\hline & Test code & 2.2 & 6.1 & 7.1 & 10.2 & 10.5 & 10.9 & & & & & & & & & & & & & & & & & \\
\hline \multirow{3}{*}{ C5 - Vey high } & Year 1 & 6,60 & 5,00 & & & & & & & & & & & & & & & & & & & & & \\
\hline & Year 2 & 11 & & & & & & & & & & & & & & & & & & & & & & \\
\hline & Test code & 1.4 & 7.3 & & & & & & & & & & & & & & & & & & & & & \\
\hline \multirow{3}{*}{ CX - Extreme } & Year 1 & 9,90 & 10,20 & & & 15 & & & & & & & & & & & & & & & & & & \\
\hline & Year 2 & 15,60 & 17,00 & 18,00 & 18,50 & & & & & & & & & & & & & & & & & & & \\
\hline & Test code & 1.2 & 1.3 & 5.1 & 5.1 & 7.5 & & & & & & & & & & & & & & & & & & \\
\hline
\end{tabular}


Table 44: Average, median and standard deviation from field tests for $\mathrm{Z}$ finishes

\begin{tabular}{lrrrr}
$\begin{array}{c}\text { Corrosivity } \\
\text { category ISO 9223 }\end{array}$ & Year & Average & \multicolumn{1}{l}{ Median } & $\begin{array}{c}\text { Standard } \\
\text { deviation }\end{array}$ \\
& & & & \\
\hline \multirow{3}{*}{ C2 - Low } & Year 1 & 0,55 & 0,55 & 0,06 \\
& Year 2 & 0,98 & 1,00 & 0,08 \\
& Year 4 & 2,24 & 2,24 & 0,62 \\
& Year 6 & 4,58 & 4,58 & 1,49 \\
\hline \multirow{3}{*}{ C3 - Medium } & Year 1 & 1,35 & 1,32 & 0,40 \\
& Year 2 & 2,33 & 2,17 & 0,78 \\
& Year 4 & 4,82 & 4,62 & 0,99 \\
& Year 6 & 9,57 & 10,07 & 2,31 \\
\hline \multirow{3}{*}{ C4 - High } & Year 1 & 2,54 & 2,56 & 0,34 \\
& Year 2 & 4,05 & 4,07 & 0,91 \\
& Year 4 & 7,23 & 7,24 & 0,47 \\
C5 - Vey high & Year 6 & 14,60 & 16,20 & 2,56 \\
\hline \multirow{2}{*}{ CX - Extreme } & Year 1 & 5,80 & 5,80 & 1,13 \\
& Year 2 & 11,00 & 11,00 & - \\
\hline \multirow{2}{*}{ Year 1 } & 11,70 & 10,20 & 0,21 \\
& Year 2 & 17,28 & 17,50 & 1,28 \\
\hline
\end{tabular}

\subsection{Boxplot charts}

\subsubsection{ZM alloys}

BoxPlot charts of the different values distribution for each corrosivity category will be presented below. The intention is to know to what extend the distribution of the different data is consistent and what level of dispersion by quartil they have.

a) $\mathrm{C} 2$ corrosivity category

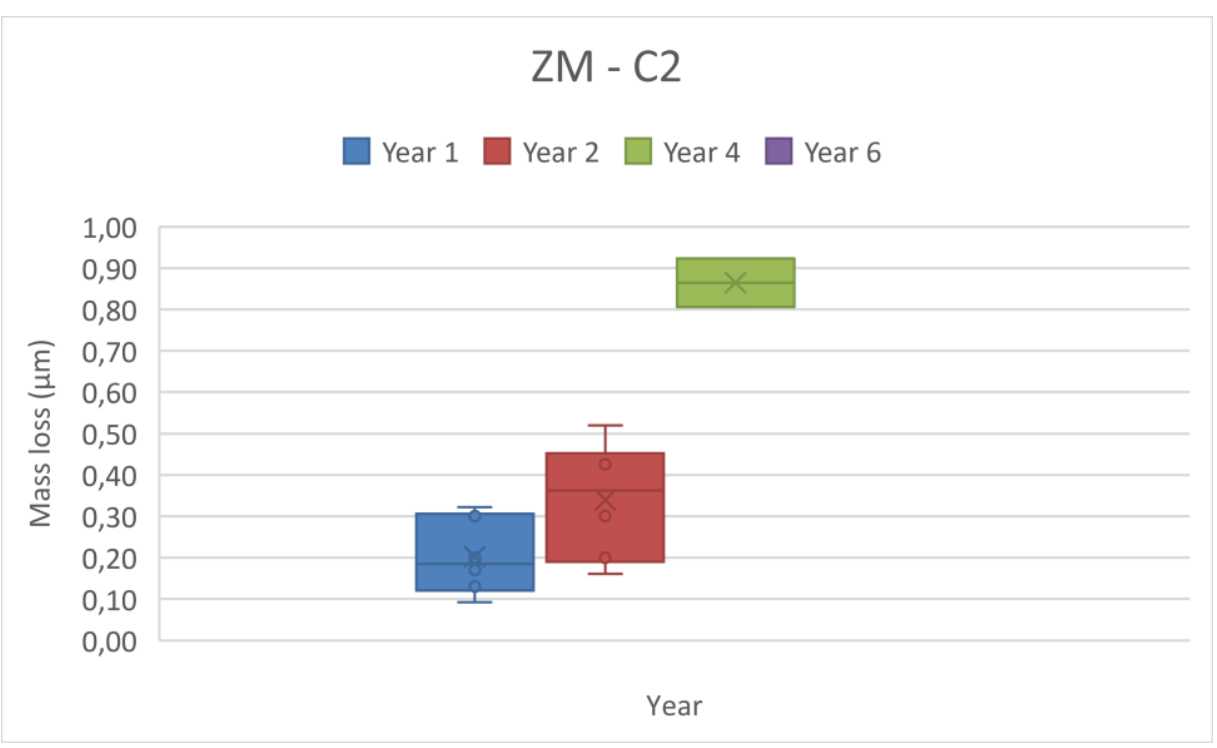

Figure 29: ZM mass loss for C2 corrosivity category boxplot chart 
For Year 1, values are quite concentrated in Q1-Q2 interquartile range, but there's no a high dispersion of values. For Year 2, there's a higher Q2-Q3 interquartile range, meaning that up to 50\% values are concentrated from 0,16 to 0,36 and the highest value $(0,52$ is a bit away from the Q1-Q3).

For Year 4, there's only 2 values, which difference is quite acceptable $(0,08 \mu \mathrm{m}$ standard deviation).

For Year 6, there's only 1 value, coming from one specific test $(1,45 \mu \mathrm{m})$. For this reason, even the result seems to be at first glance quite coherent in terms of corrosion evolution, it must be carefully taken.

b) C3 corrosivity category

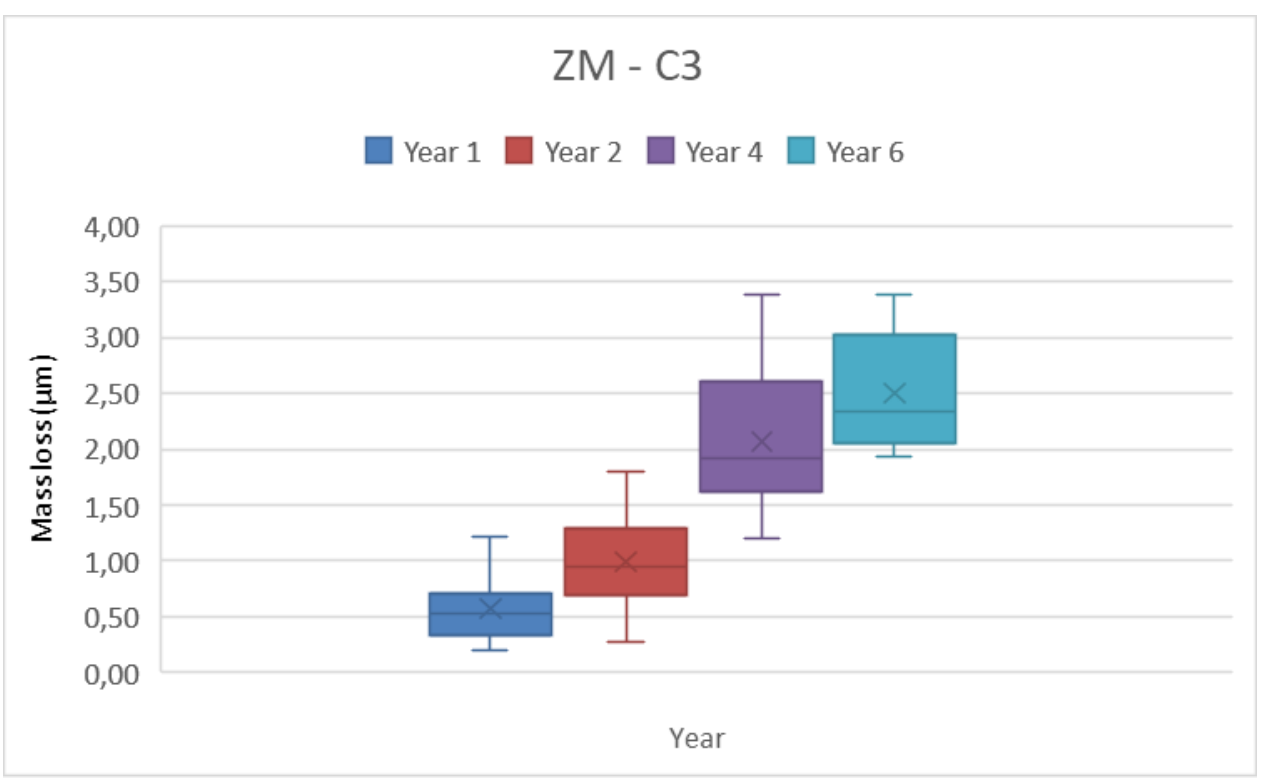

Figure 30: ZM mass loss for C3 corrosivity category boxplot chart

This corrosivity category is the one with the highest number of values, especially for year 1 and year 2 , which makes the statistical analysis more accurate.

For the case of year 1, it can be observed that there's a higher concentration of values in the interquartile range of Q2-Q3 (between 0,34 and 0,7 $\mu \mathrm{m}$ ), being the average value of $0,57 \mu \mathrm{m}$.

There's a higher dispersion for the quartile Q4 caused mostly by a few values above $1 \mu \mathrm{m}$, especially the value of $1,21 \mu \mathrm{m}$.

For the case of year 2 , the distribution is very uniform with an average of $0,99 \mu \mathrm{m}$ and $0,42 \mu \mathrm{m}$ standard deviation. For the case of year 4, there's a higher dispersion with a standard deviation of 0,66 $\mu \mathrm{m}$. Looking at the chart for 50 to $100 \%$ of the higher values are concentrated between 1,61 and $2,60 \mu \mathrm{m}$, being the average of $2,07 \mu \mathrm{m}$. For the case of year 6 , distribution is quite similar to year 4 , but with a lower standard deviation.

As will be seen later when analysing the evolution of averages, the fact of having more values in this corrosivity category, gives a general chart, where evolution of the ranges can be clearly seen, in a gradual progression. 
c) C4 corrosivity category

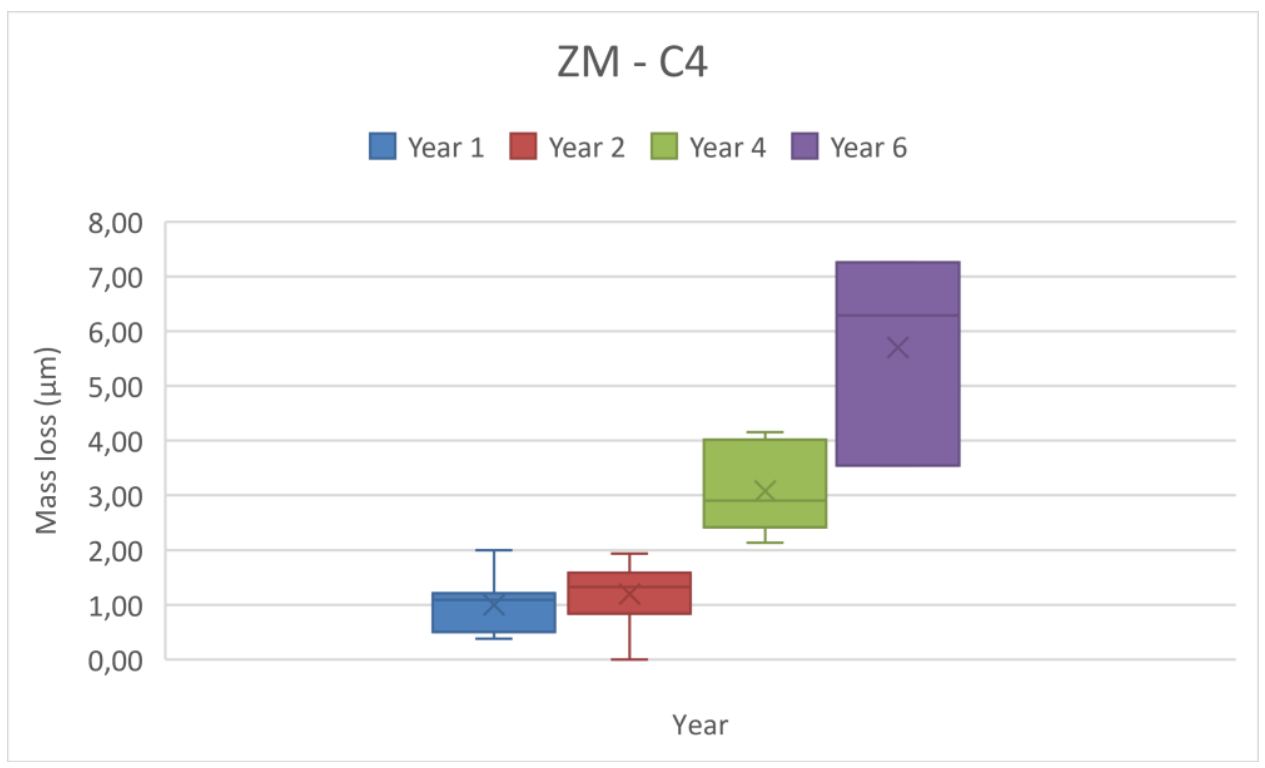

Figure 31: ZM mass loss for C4 corrosivity category boxplot chart

For this corrosivity category, there are less values where for year 4 and year 6 we have a higher dispersion. When it comes to year 1 and year 2 the dispersion is very low, with an average value of 1 and 1,34 respectively and a standard deviation of 0,47 and $0,37 \mu \mathrm{m}$.

For the case of year 6 , there are only 3 values: one of them $(3,55 \mu \mathrm{m})$ not aligned with the other $2(6,29$ and 7,26 $\mu \mathrm{m})$, that's why the size of the box here is much higher than for the rest corrosivity categories.

d) C5 corrosivity category

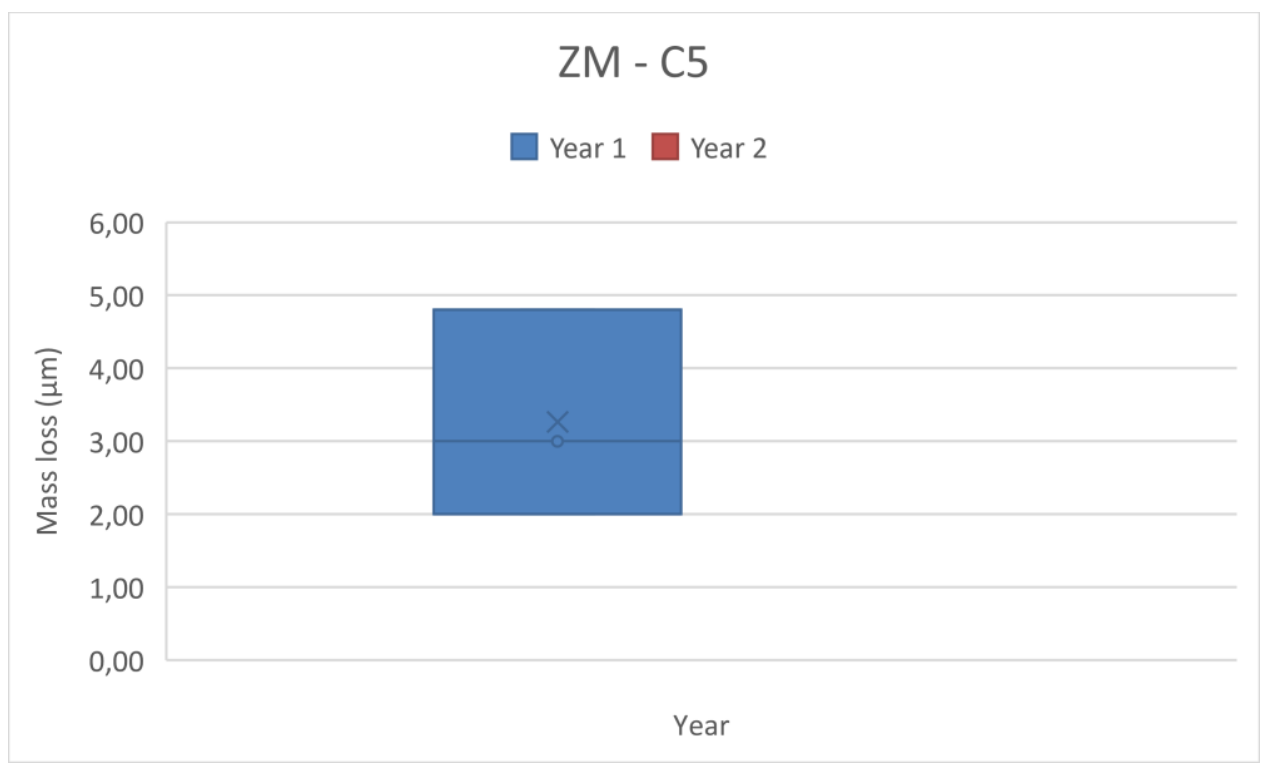

Figure 32: ZM mass loss for C5 corrosivity category boxplot chart

There are only three values for year 1 and one value for year 2, which makes that these values have to be taken very carefully when drawing conclusions. 
e) CX corrosivity category

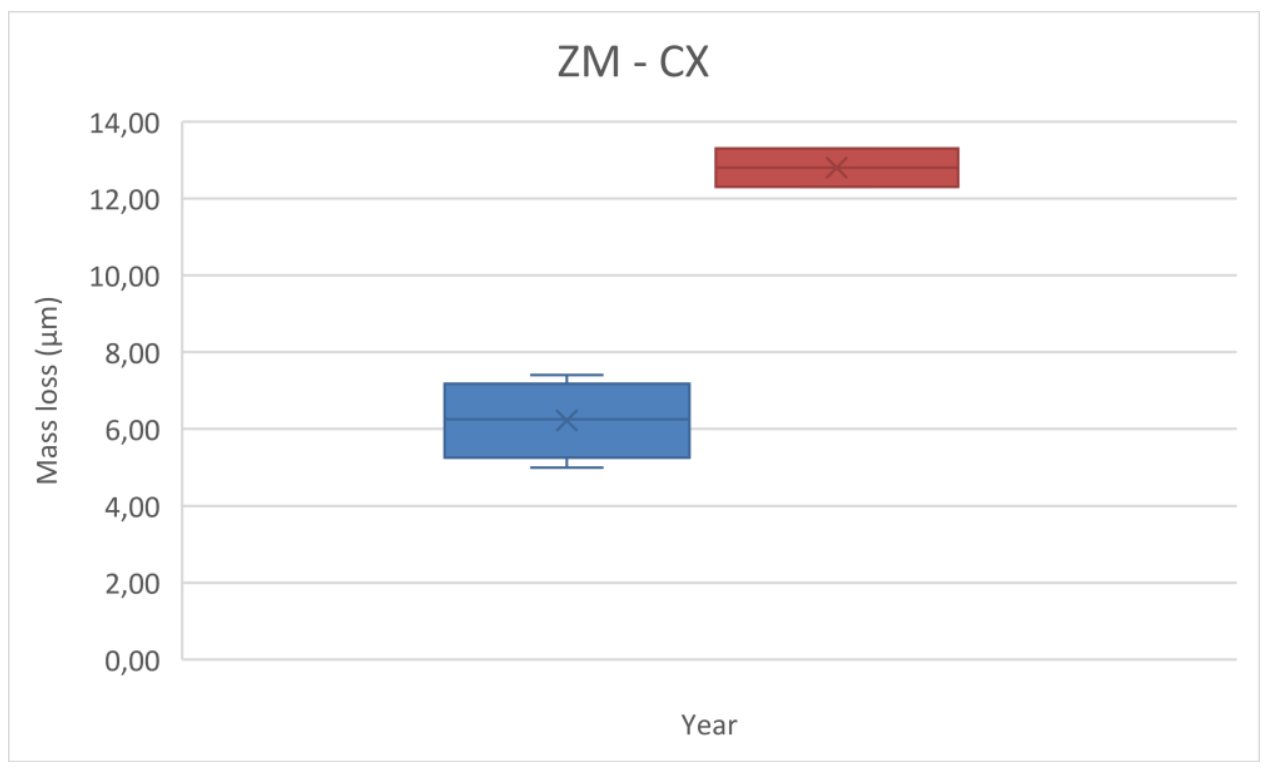

Figure 33: ZM mass 93os for CX corrosivity category boxplot chart

In the same way than for C5 corrosivity class, there are few values for both year 1 and year 2 . The good point here is that the dispersion is not too high.

For the case of year 1 , the average is $6,23 \mu \mathrm{m}$ with a standard deviation of $1 \mu \mathrm{m}$, and for the case of year 2 , the average is $12,80 \mu \mathrm{m}$ and the standard deviation of $0,71 \mu \mathrm{m}$.

\subsubsection{Zinc coatings}

a) C2 corrosivity category

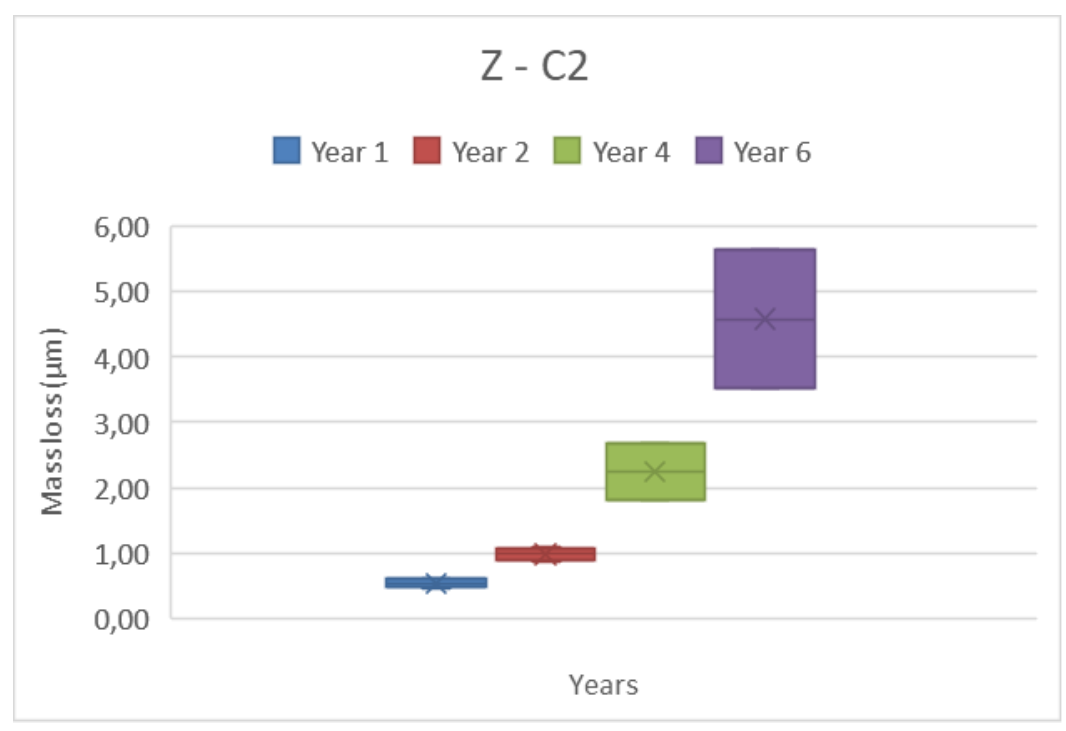

Figure $34: \mathrm{Z}$ mass loss for $\mathrm{C} 2$ corrosivity category boxplot chart

The dispersion in general is very little for year 1 and year 2 as can clearly be seen in the chart, as well as in the values or their standard deviation: 0,06 and $0,08 \mu \mathrm{m}$, respectively.

For the cases of year 4 and year 6 there are only 2 values for each of this corrosivity categories; that's why, these values have to be taken very carefully when drawing conclusions. In addition, for the case of year 6 , these 2 values have an important gap $(1,49 \mu \mathrm{m}$ of standard deviation $)$.

Finally, it is important to highlight the progression of the mass loss in the box charts with a logarithmic behaviour. 
b) C3 corrosivity category

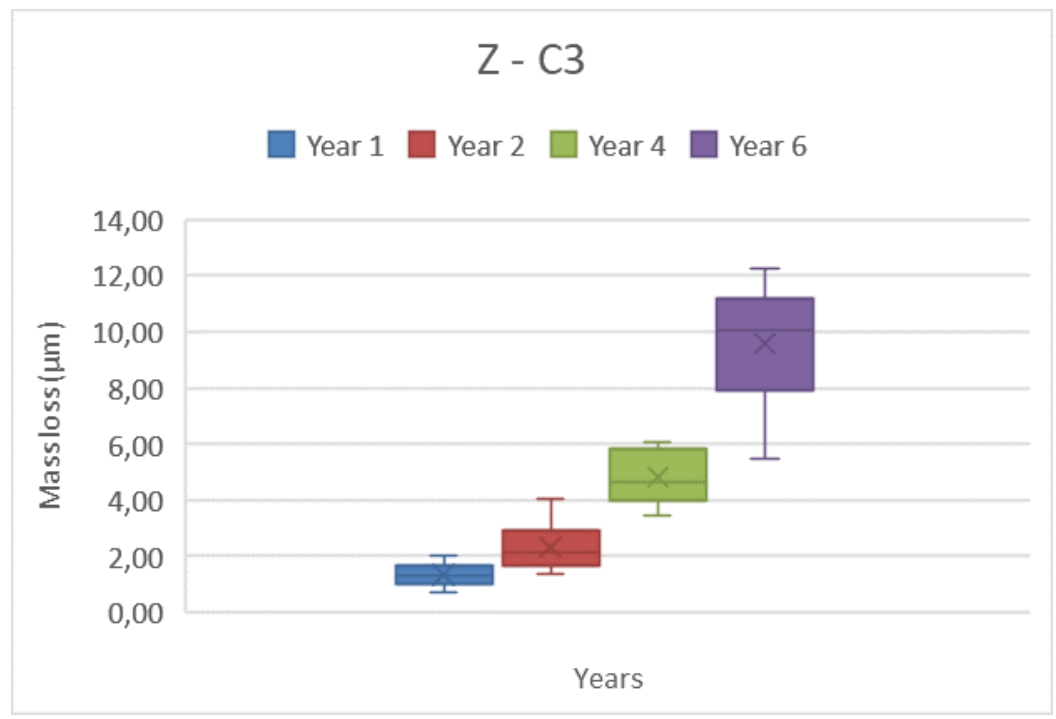

Figure 35: $\mathrm{Z}$ mass loss for $\mathrm{C} 3$ corrosivity category boxplot chart

As well as for the ZM alloys, for this corrosivity category is for which there are more values and that's why we can have an accurate statistical analysis.

For the case of years 1 and 2, the dispersion is very little with a couple of points out of the range. For the specific case of year 2, points located in the 3 first quartiles are below 2,9 $\mu \mathrm{m}$.

For the case of year 4, dispersion is also quite acceptable, with an average of $4,82 \mu \mathrm{m}$ and a standard deviation of $0,99 \mu \mathrm{m}$

In the same way that for $\mathrm{C} 2$ corrosivity class, the progression of the mass loss also follows a similar logarithmic curve.

c) C4 corrosivity category

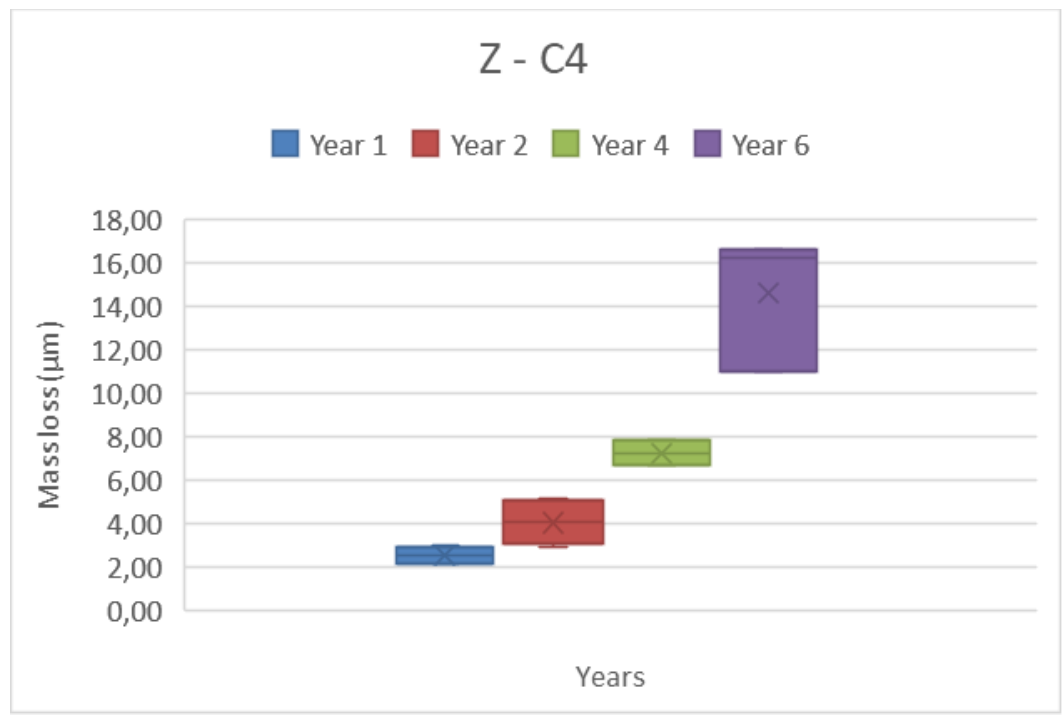

Figure 36: $\mathrm{Z}$ mass loss for $\mathrm{C} 4$ corrosivity category boxplot chart

As it clearly can be seen in the charts, for the cases of year 1, year 2 and year 3 the dispersion is very little.

For the case of year 4 and year 6 there are only 3 values, thus these values have to be taken very carefully when drawing conclusions.

In the same way that for $\mathrm{C} 2$ and $\mathrm{C} 3$ corrosivity classes, the progression of the mass loss also follows a similar logarithmic curve. 
d) C5 corrosivity category

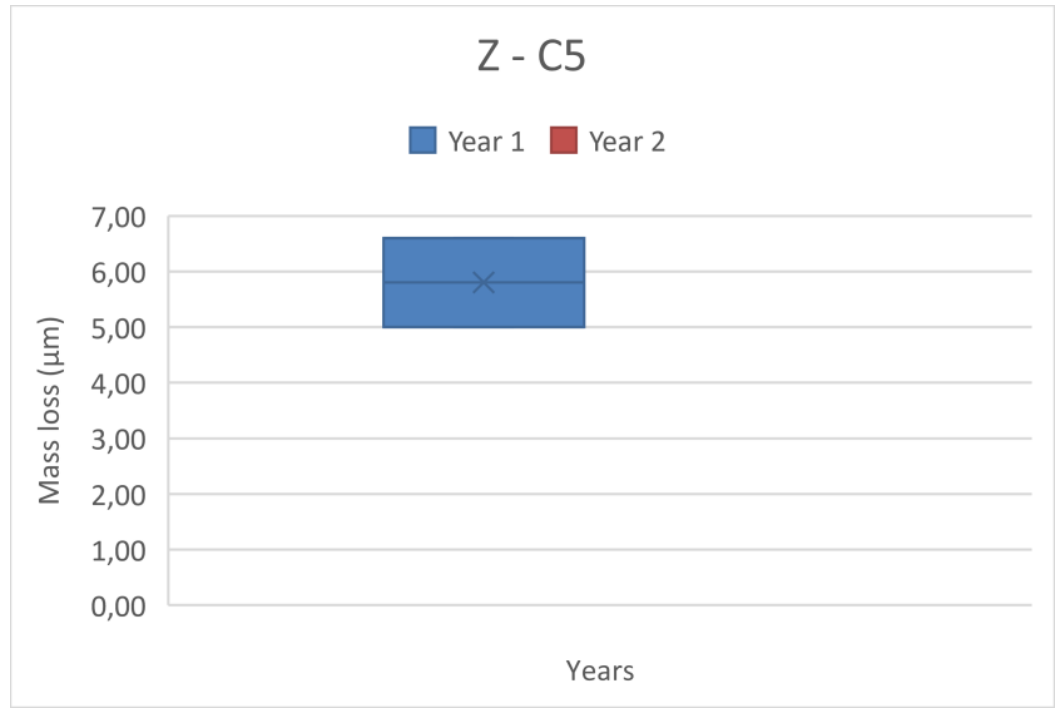

Figure 37: Z mass 95os for C5 corrosivity category boxplot chart

There are only values for year 1 and year 2 for this corrosivity category and for the case of year 2 there's only one value. That's why these values have to be taken very carefully when drawing conclusions and the interpretation of the boxplot chart is not relevant in this case.

e) CX corrosivity category

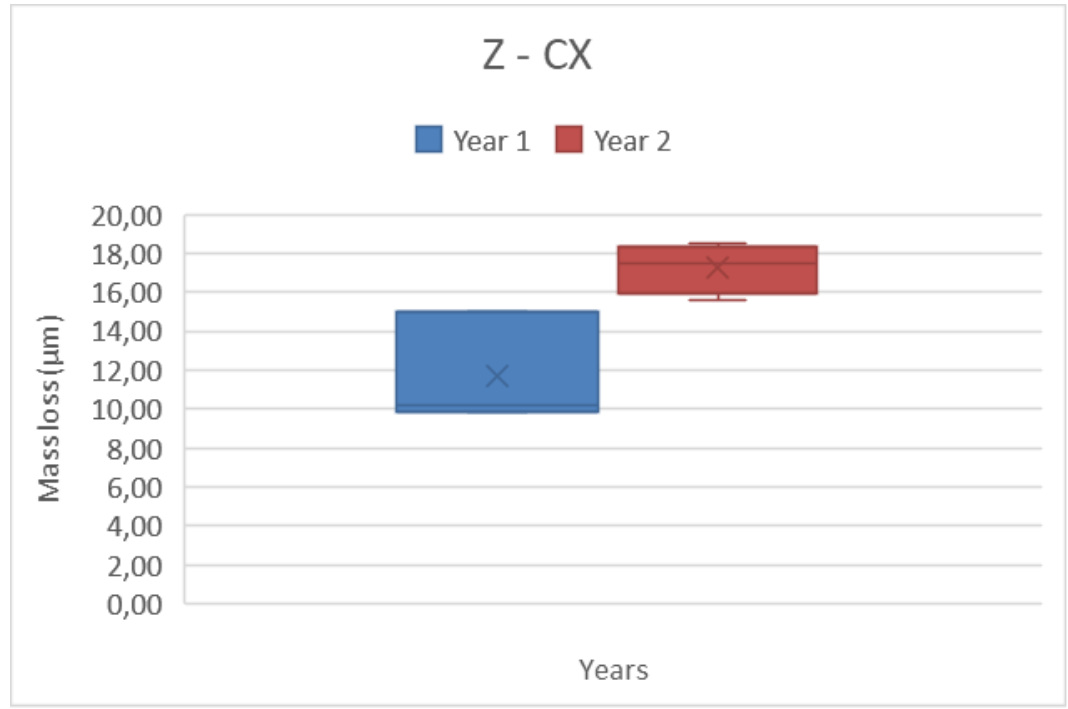

Figure 38: $\mathrm{Z}$ mass loss for $\mathrm{CX}$ corrosivity category boxplot chart

For the case of year 1 there are only 3 values and the chart shows the gap between 2 of them $(9,90$ and 10,20 $\mu \mathrm{m})$ and the other $(15 \mu \mathrm{m})$.

For the case of year 2, there's a lower dispersion with an average of 17,28 $\mu \mathrm{m}$ and a standard deviation of 1,28 $\mu \mathrm{m}$.

\subsection{Average linear charts}

In this subclause, it will be analysed the behaviour of corrosion based in the evolution of the yearly mass loss average over time. 
Table 45 summarizes the average mass loss classified by corrosivity category according to ISO 9223 and its evolution by year. It also includes the difference between $\mathrm{ZM}$ and $\mathrm{Z}$ mass loss. It contains the values for ZM and $\mathrm{Z}$ finishes. These values are extracted from Table 41 and Table 44.

Table 45: Average mass loss of $\mathrm{Z}$ and $\mathrm{ZM}$ finishes $(\mu \mathrm{m})$

\begin{tabular}{lcccc}
$\begin{array}{c}\text { Corrosivity } \\
\text { category ISO 9223 }\end{array}$ & Year & Average ZM & Average Z & Gap ZM-Z \\
\hline \multirow{3}{*}{ C2 - Low } & Year 1 & 0,20 & 0,55 & 0,35 \\
& Year 2 & 0,34 & 0,98 & 0,64 \\
& Year 4 & 0,86 & 2,24 & 1,37 \\
& Year 6 & 1,45 & 4,58 & 3,13 \\
\hline \multirow{3}{*}{ C3 - Medium } & Year 1 & 0,57 & 1,35 & 0,78 \\
& Year 2 & 0,99 & 2,33 & 1,34 \\
& Year 4 & 2,07 & 4,82 & 2,76 \\
& Year 6 & 2,50 & 9,57 & 7,07 \\
\hline \multirow{3}{*}{ C4 - High } & Year 1 & 1,00 & 2,54 & 1,54 \\
& Year 2 & 1,34 & 4,05 & 2,70 \\
& Year 4 & 3,08 & 7,23 & 4,15 \\
C5 - Very high & Year 6 & 5,70 & 14,60 & 8,90 \\
& Year 1 & 3,27 & 5,80 & 2,53 \\
\hline \multirow{2}{*}{ CX - Extreme } & Year 2 & 9,20 & 11,00 & 1,80 \\
\hline
\end{tabular}

The graphs showing the evolution over time for each corrosivity category will be represented below in Figure 39, Figure 40, Figure 41, Figure 42 and Figure 43. It must be noticed that the mass loss expressed in $\mu \mathrm{m}$ is accumulative year after year. For instance, the mass loss for year 4 corresponds to the sum of year 1 , year 2 and year 3 . This is why in all the charts below the curves are always positive, because it represents the cumulative mass loss along the time.

a) Corrosivity category $\mathrm{C} 2$

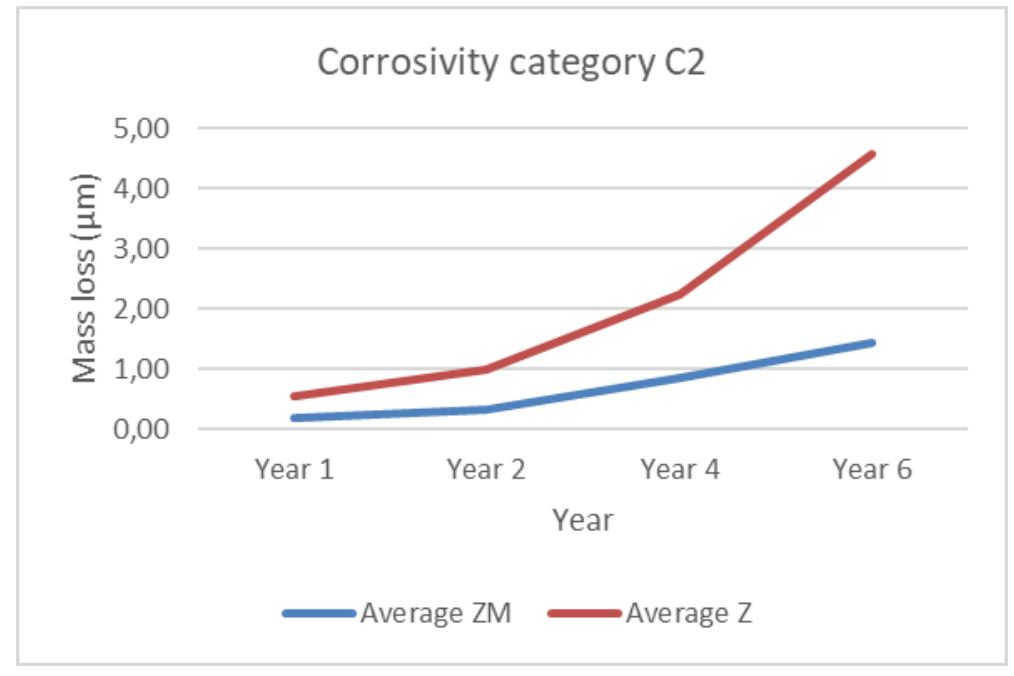

Figure 39: Mass loss evolution over time for C2 corrosivity category

These are the main conclusions that can be drawn from the chart:

- In all years, the mass loss is higher for $\mathrm{Z}$ finish 
- The slope of the curve is higher for the $\mathrm{Z}$ finish, while for $\mathrm{ZM}$ is almost linear, mostly in the 2 last years.

- The gap between $\mathrm{ZM}$ and $\mathrm{Z}$ is increasing over time, starting for year 1 with a gap of $0,35 \mu \mathrm{m}$ and ending for year 6 with a gap of $3,13 \mu \mathrm{m}$.

b) Corrosivity category $\mathrm{C} 3$

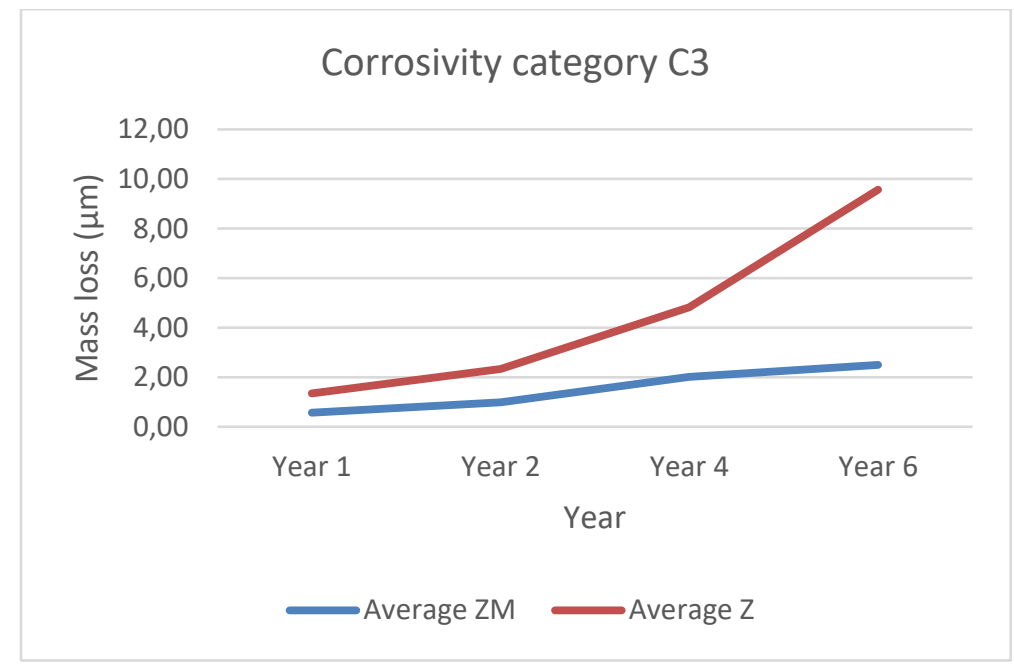

Figure 40: Mass loss evolution over time for C3 corrosivity category

These are the main conclusions that can be drawn from the chart:

- In all years, the mass loss is higher for $\mathrm{Z}$ finish

- The slope of the curve is much higher for the $\mathrm{Z}$ finish, while for $\mathrm{ZM}$ is almost linear.

- The gap between $\mathrm{ZM}$ and $\mathrm{Z}$ is increasing over time, starting for year 1 with a gap of $0,78 \mu \mathrm{m}$ and ending for year 6 with a gap of $7,07 \mu \mathrm{m}$.

- It must be noticed how fast this gap is increased over time, especially in year 6 .

c) Corrosivity category $\mathrm{C} 4$

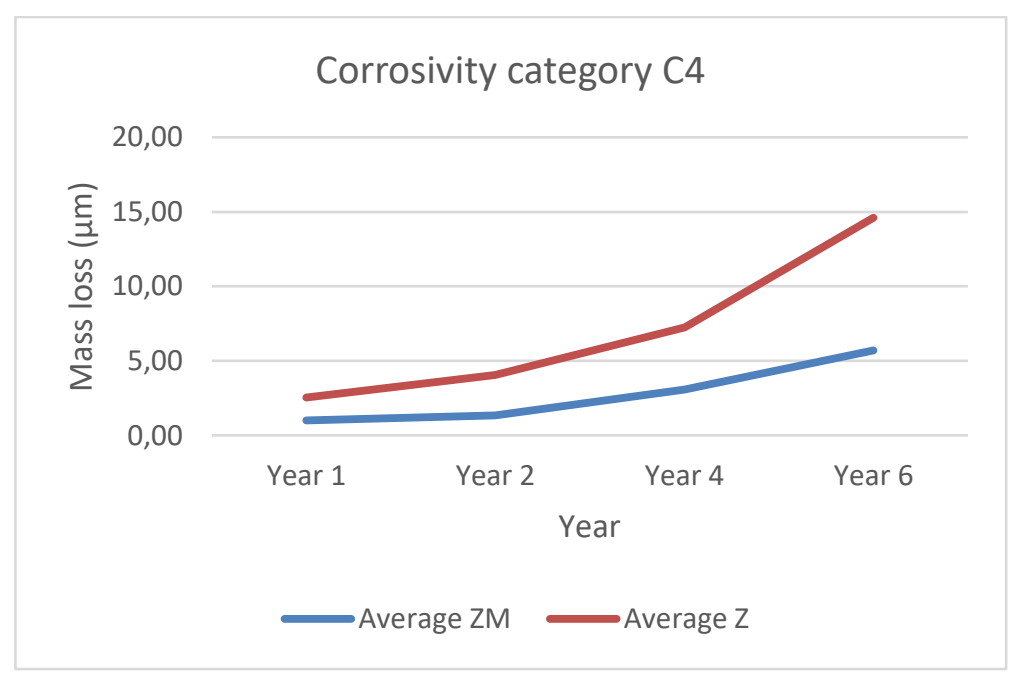

Figure 41: Mass loss evolution over time for C4 corrosivity category

These are the main conclusions that can be drawn from the chart:

- In all years, the mass loss is higher for $\mathrm{Z}$ finish 
- The slope of the curve is slightly higher for the $\mathrm{Z}$ finish for year 1, year 2 and year 4 . For year 6 the slope is significantly higher.

- The gap between $\mathrm{ZM}$ and $\mathrm{Z}$ is increasing over time, mostly in year 6 where the slope is accentuated. This gap starts for year 1 with a gap of $1,54 \mu \mathrm{m}$ and ending for year 6 with a gap of $8,90 \mu \mathrm{m}$.

d) Corrosivity category C5

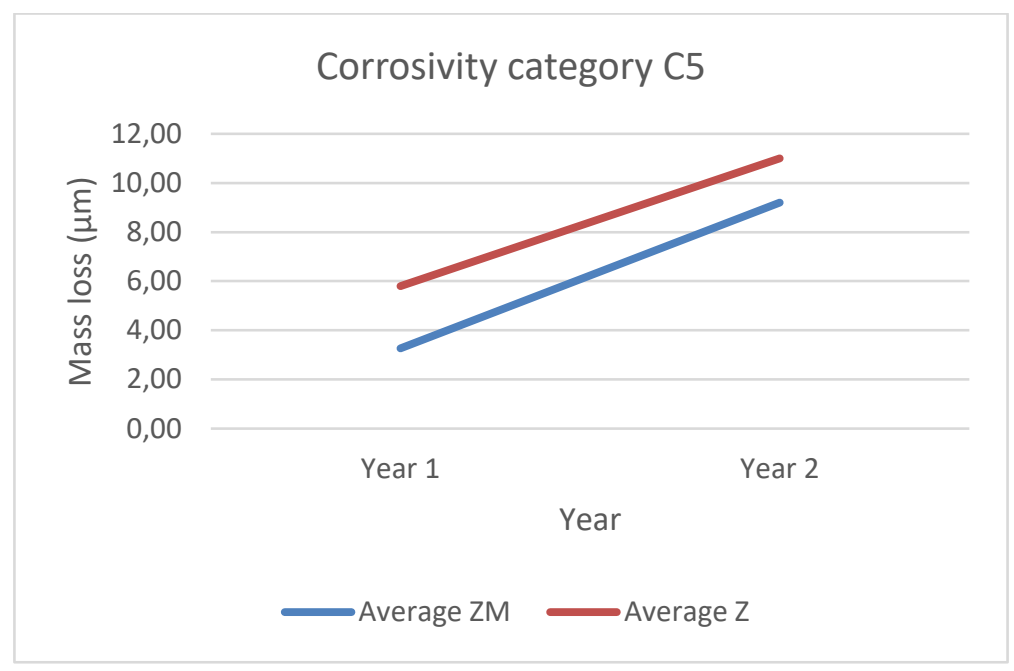

Figure 42: Mass loss evolution over time for C5 corrosivity category

- In all years, the mass loss is higher for $\mathrm{Z}$ finish

- The slope of the curve is almost the same for both finishes and they are almost linear as well.

- Unlike for the previous corrosivity categories, the gap between $\mathrm{ZM}$ and $\mathrm{Z}$ is almost the same over time, with a slight decreasing, starting for year 1 with a gap of $1,78 \mu \mathrm{m}$ and ending for year 2 with a gap of $1,20 \mu \mathrm{m}$.

- The trend seems to indicate that the two curves tend to join in time, but still, the number of years is too few to foresee any tendency.

e) Corrosivity category CX

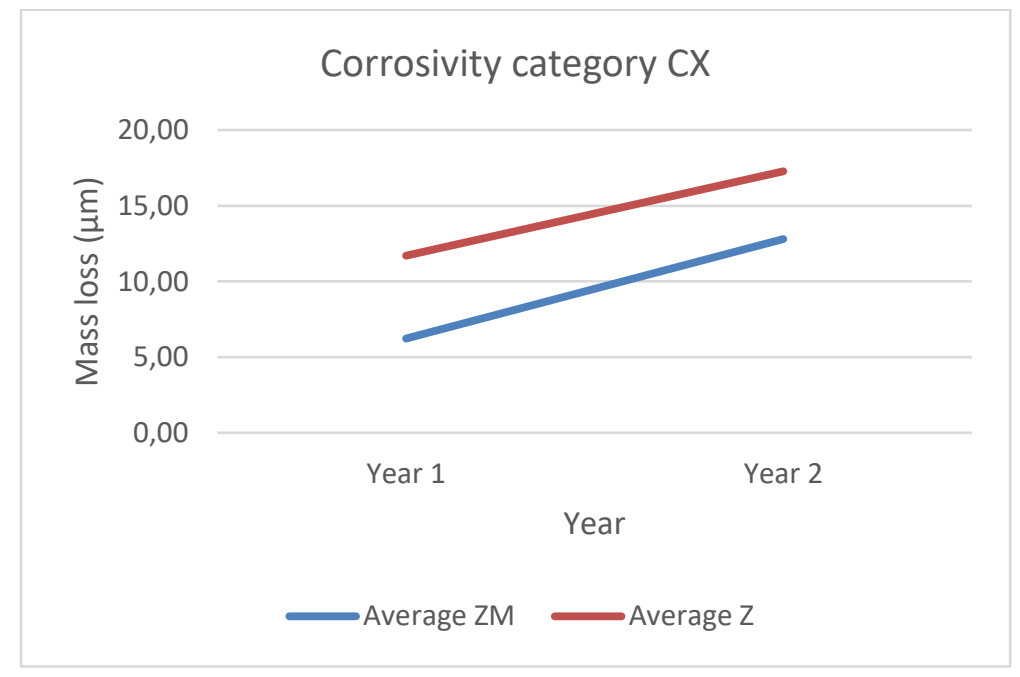

Figure 43: Mass loss evolution over time for CX corrosivity category 
- In all years, the mass loss is higher for $\mathrm{Z}$ finish

- The slope of the curve is almost the same for both finishes and they are almost linear as well.

- As well as in C5 corrosivity category, the gap between ZM and Z is almost the same over time, with a slight decreasing, starting for year 1 with a gap of 5,48 $\mu \mathrm{m}$ and ending for year 2 with a gap of 4,48 $\mu \mathrm{m}$.

- The trend seems to indicate that the two curves tend to join in time, but still, the number of years is too few to foresee any tendency.

\subsection{Global evolution between $\mathrm{Z}$ and $\mathrm{ZM}$ average mass loss}

In the previous clause, it was seen a first analysis about how the differences in terms of mass loss between $\mathrm{Z}$ and $\mathrm{ZM}$ were progressing. These values are given in Table 45. In this section, it will be analysed the general progression, looking at them in a global view.

For this purpose, it will be used Figure 44 where a graphic representation has been done, showing the evolution in time of each corrosivity category, and inside each, the evolution over time.

Several conclusions can be drawn from this chart:

- In general terms, looking at the exponential curves, the gap ( $\mathrm{Z}$ mass loss minus ZM mass loss) is uniformly increased from left to right, i.e., with the increase of corrosivity class and over time.

- Maximum gap is given in C4 corrosivity category, where it reaches for year 6, 8,90 $\mu \mathrm{m}$.

- $\quad$ The corrosivity category with a higher average gap corresponds to CX $(4,98 \mu \mathrm{m})$.

- Is quite visible in the chart the big increase of mass loss for zinc in year 6 for all corrosivity categories, especially in C3 and C4, where the gap between year 4 and year 6 is 4,31 and 4,75 $\mu \mathrm{m}$, respectively.

- $\quad$ For ZM finishes, the slopes increase from left to right, i.e., with the increase of corrosivity class and over time. They are specially pronounced for C5 and CX.

- For corrosivity categories C5 and CX, the behaviour is quite similar between Z and ZM, actually, the slope of the lines is almost the same with a small gap in between. Thus, according to this, seems that for the harshest environments (C5, CX), the gap between both coatings tends to be more aligned than for the rest $(\mathrm{C} 2, \mathrm{C} 3, \mathrm{C} 4)$ where there's a clear difference in favour of $\mathrm{ZM}$ alloys.

- $\quad$ None of the chart shows in this 6-year analysis, a logarithmic behaviour, neither for Z nor for ZM finishes. For the case of $Z$ finishes, as it was seen in the background clauses, it has been proven that this behaviour is logarithmic across the years. Thus, the conclusion here is that 6-years analysis is not enough to determine if for the case of $\mathrm{Z}$ finishes, the behaviour will be also logarithmic and if so, what type of logarithmic mathematical model will follow. Therefore, this is a point to keep for future investigation research on this subject. 


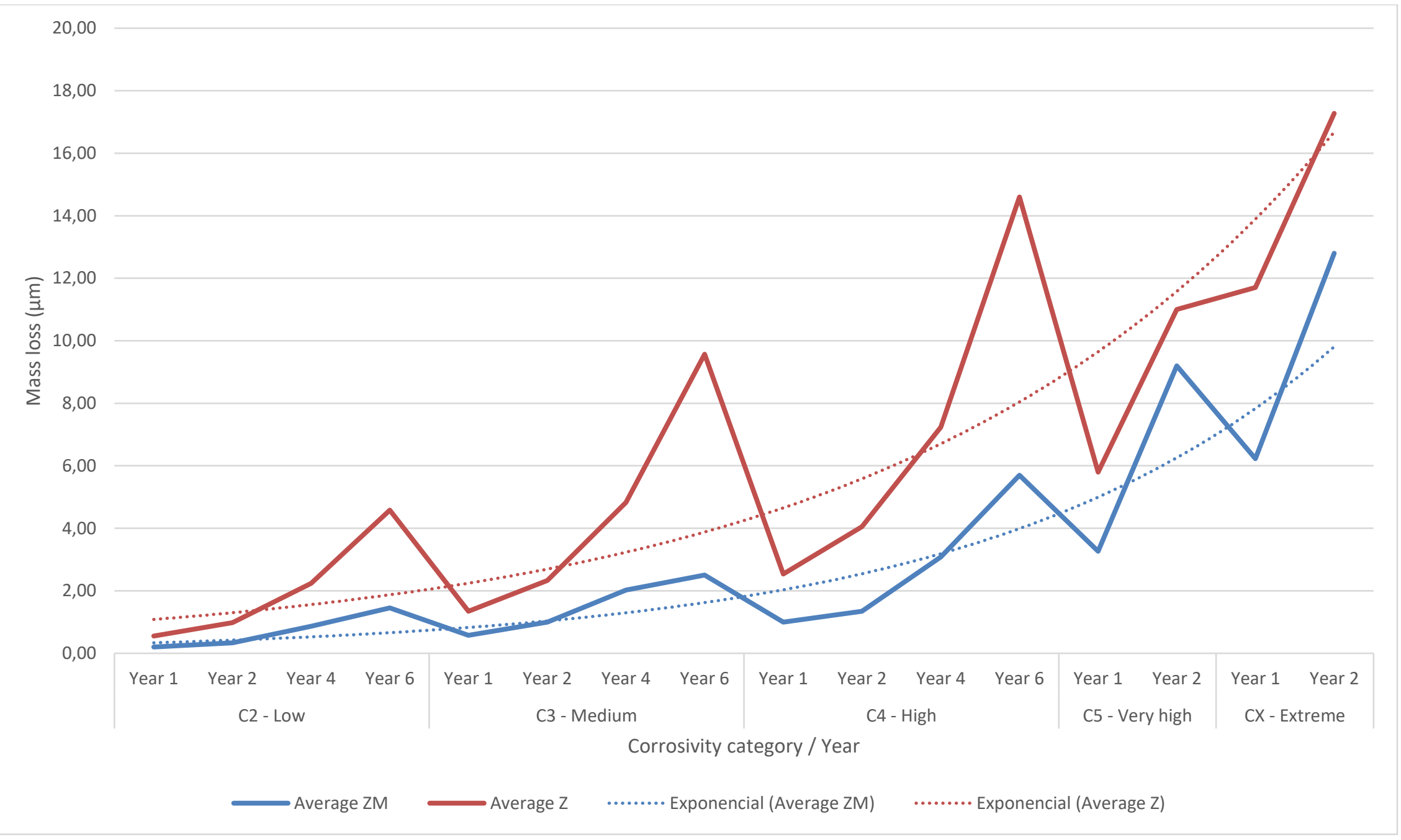

Figure 44: Mass loss yearly average evolution for $\mathrm{Z}$ and $\mathrm{ZM}$ coatings 


\subsection{Ratios $Z-Z M$ and $Z / Z M$ evolution over the time}

A further analysis is required when compare the behaviour between $\mathrm{ZM}$ and $\mathrm{Z}$ alloys, based in 2 indicators:

a) Difference between $\mathrm{Z}$ and $\mathrm{ZM}$ mass loss

b) Ratio Z/ZM mass loss

Table 46 shows the values of both indicators and Figure 47 shows their evolution over time and per corrosivity category.

Table 46: Average, gap ZM-Z and ratio Z/ZM yearly evolution by corrosivity class

\begin{tabular}{lcrrrr}
$\begin{array}{c}\text { Corrosivity category } \\
\text { ISO 9223 }\end{array}$ & Year & Average ZM & Average Z & Gap Z-ZM & $\begin{array}{c}\text { Performance } \\
\text { ratio Z/ZM }\end{array}$ \\
\hline \multirow{3}{*}{ C2 - Low } & Year 1 & 0,20 & 0,55 & 0,35 & 2,73 \\
& Year 2 & 0,34 & 0,98 & 0,64 & 2,90 \\
& Year 4 & 0,86 & 2,24 & 1,37 & 2,59 \\
& Year 6 & 1,45 & 4,58 & 3,13 & 3,15 \\
\hline \multirow{3}{*}{ C3 - Medium } & Year 1 & 0,57 & 1,35 & 0,78 & 2,36 \\
& Year 2 & 0,99 & 2,33 & 1,34 & 2,34 \\
& Year 4 & 2,02 & 4,82 & 2,76 & 2,39 \\
& Year 6 & 2,50 & 9,57 & 7,07 & 3,83 \\
\hline \multirow{3}{*}{ C4 - High } & Year 1 & 1,00 & 2,54 & 1,54 & 2,54 \\
& Year 2 & 1,34 & 4,05 & 2,70 & 3,01 \\
& Year 4 & 3,08 & 7,23 & 4,15 & 2,35 \\
\hline \multirow{2}{*}{ C5 - Very high } & Year 6 & 5,70 & 14,60 & 8,90 & 2,56 \\
\hline \multirow{2}{*}{ CX - Extreme } & Year 1 & 3,27 & 5,80 & 2,53 & 1,78 \\
& Year 2 & 9,20 & 11,00 & 1,80 & 1,20 \\
\hline
\end{tabular}

These are the main conclusions that can be drawn:

- According to the average values obtained for the indicator Z-ZM (Table 47), the trend line shows a clear rising slope as it can be seen in (Figure 45). This effect was seen in previous sections. With the exceptions of C5 and CX, this gap increases over the years, being especially relevant in C3 and C4 corrosivity categories (7,07 and 8,9 $\mu \mathrm{m}$, respectively, for year 6). With the information currently available, and for which data are only available for 6 years of exposure it is difficult to foresee what the future behaviour of this trend line will be. Thus, this is an important point to consider for future research.

Table 47: Average of mass loss for Z-ZM ratio by corrosivity category

\begin{tabular}{cc}
$\begin{array}{c}\text { Corrosivity category } \\
\text { ISO 9223 }\end{array}$ & Average Z-ZM \\
\hline C2 & 1,37 \\
C3 & 3,00 \\
C4 & 4,32 \\
C5 & 2,17 \\
CX & 4,98 \\
\hline
\end{tabular}




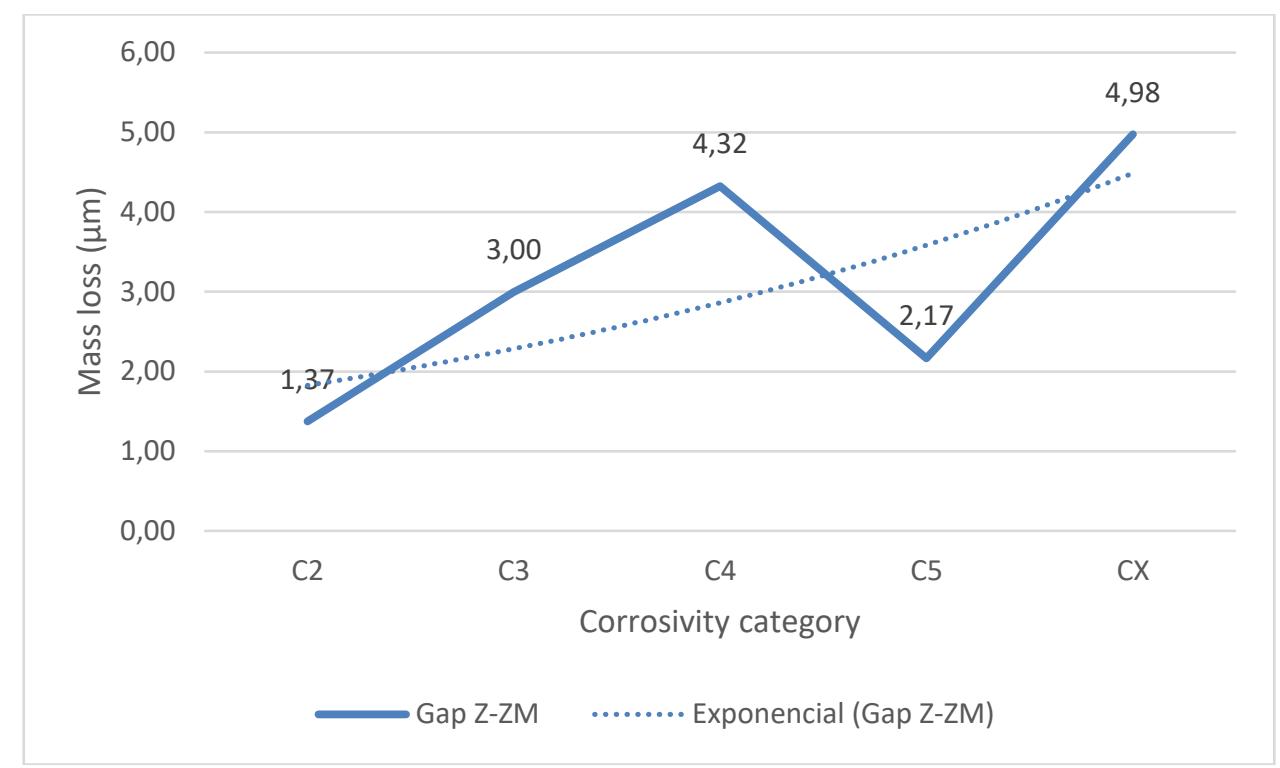

Figure 45: Evolution of the average of Z-ZM ratio along corrosivity categories

- Regarding the indicator Z/ZM, according to Figure 47 a clear decreasing trend can be observed. That means, that with the current available data, the higher the corrosivity category is, the lower the difference of performance between $\mathrm{Z}$ and ZM coatings is. In order to analyse this effect more in detail, it has been calculated the average of this ratio by corrosivity class. Table 48 shows these values. It contains the average of the ratio Z/ZM for each of the years and for each corrosivity category. After, a graphical representation of the evolution is shown in Figure 46. In this figure it can be clearly observed how the ration Z/ZM decreases as soon as the corrosivity category is higher. There's only one exception between $\mathrm{C} 5$ and $\mathrm{CX}$ where is a slight increase. It must not be forgotten here that the number of values for these corrosivity category is too small, so again, this must be carefully taken, and the main conclusion here is that, independently of future research works, the ratio Z/ZM decreases in general as soon as corrosivity category increases. This is easily observed looking at the exponential trend line in Figure 46.

Table 48: Average of mass loss for Z/ZM ratio by corrosivity category

\begin{tabular}{cc}
$\begin{array}{c}\text { Corrosivity category } \\
\text { ISO 9223 }\end{array}$ & $\begin{array}{c}\text { Average } \\
\text { Z/ZM }\end{array}$ \\
\hline C2 & 2,84 \\
C3 & 2,73 \\
C4 & 2,61 \\
C5 & 1,49 \\
CX & 1,61 \\
\hline
\end{tabular}




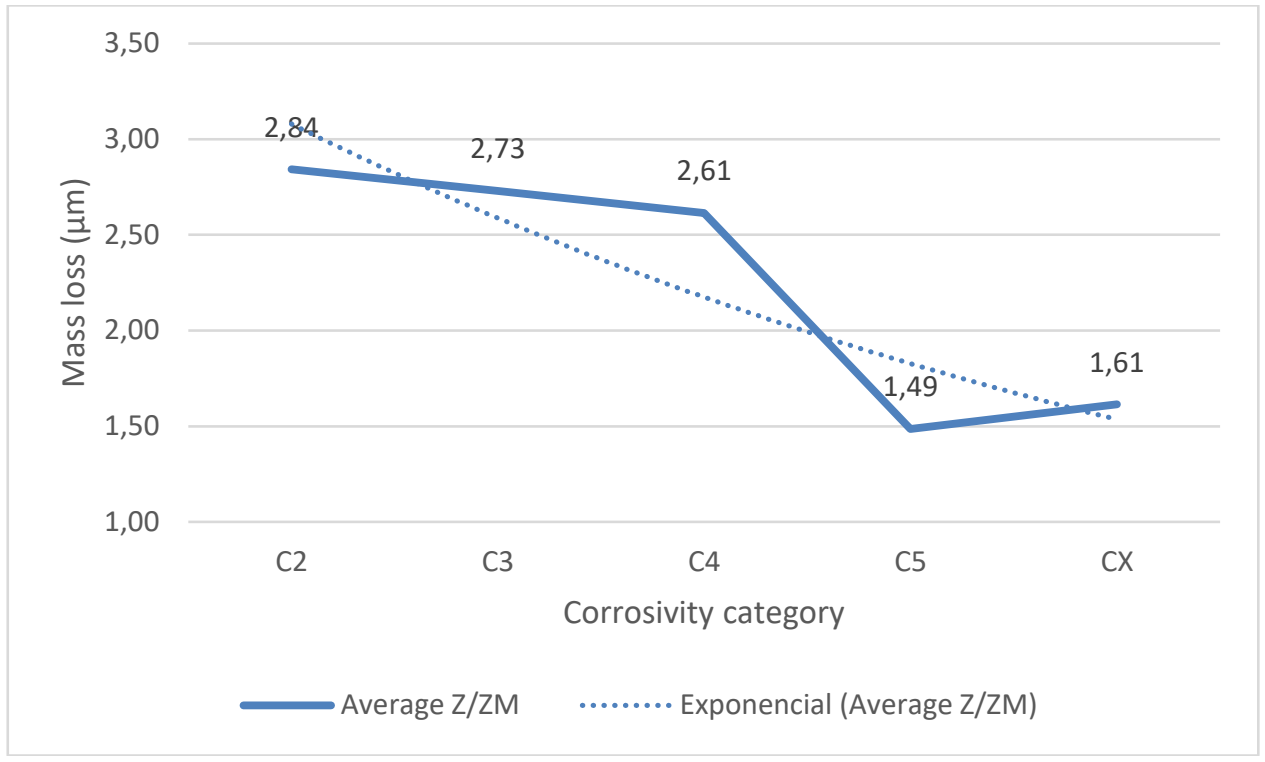

Figure 46: Evolution of the average of Z/ZM ratio along corrosivity categories 


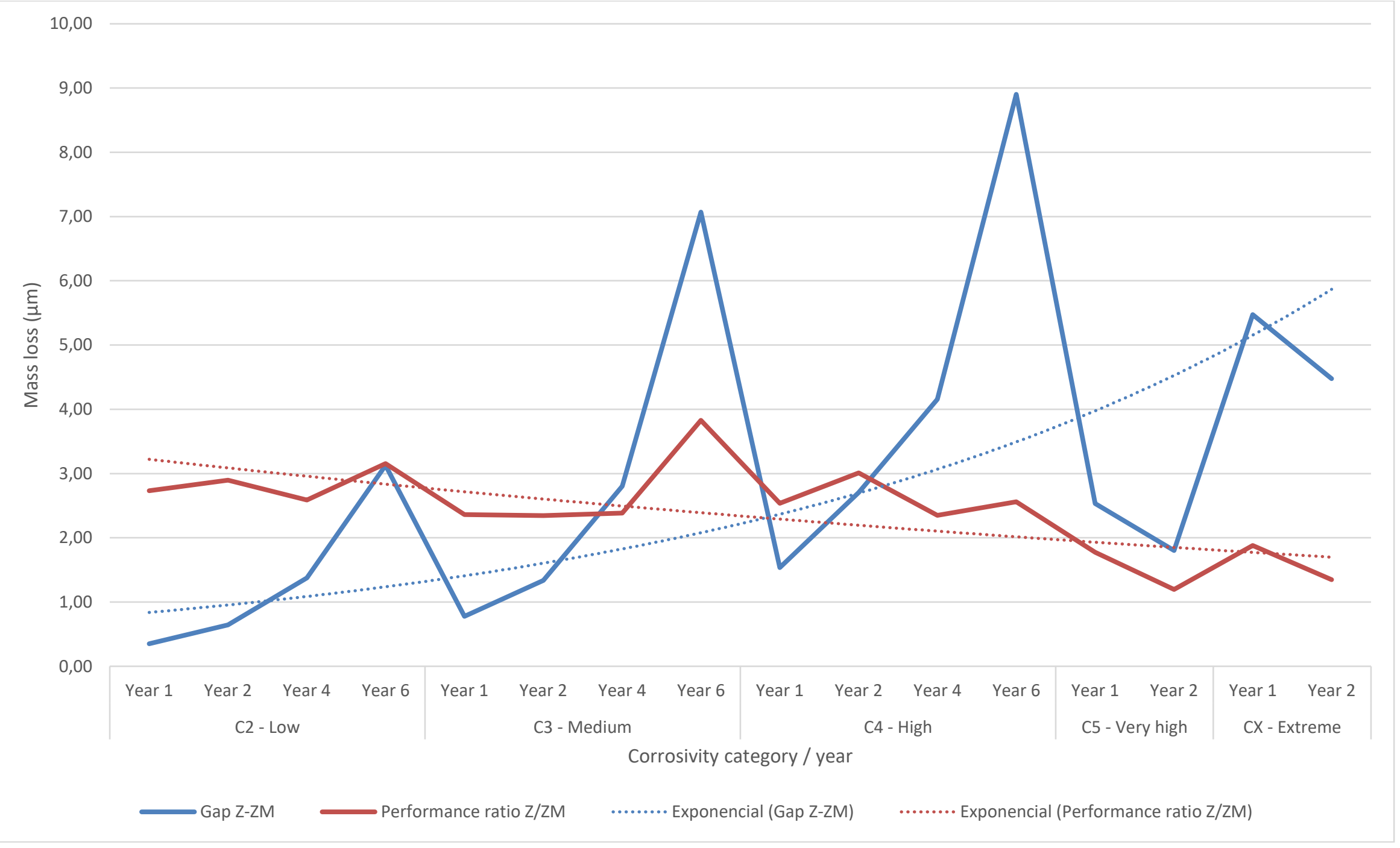

Figure 47: Yearly evolution of Z-ZM and Z/ZM indicators by corrosivity category 


\subsection{The behaviour of $\mathrm{ZM}$ alloys during the first years of exposure}

\subsubsection{Background}

Associations of galvanizers, like the European General Galvanizers Association (Association, 2020) or the Asociación Técnica Española de Galvanización (Galvanización, 2020), claims that the behaviour of ZM alloys in front of $\mathrm{Z}$ is different, in the sense that over subsequent years of exposure, conventional zinc coatings have much lower corrosion rates and remain more stable than ZM coatings, mainly due to patina formation at the surface (Rus, 2019). In other words, what is being claimed, is that in long term exposure tests, mass loss ratio Z/ZM, is much higher in the firsts years and it tends to 1 over the years and so, the comparative performance of postgalvanized and ZM coatings is distorted in favour of ZM coated steels by focusing on the early years of such tests. This is a relevant matter that has being investigated in the scope of this thesis, taken the opportunity of having 4 years field tests results (Dominique Thierry, Persson, et al., 2019)(Persson et al., 2017)(Dominique Thierry, LeBozec, et al., 2019b) and 6 years field tests results (Dominique Thierry, LeBozec, Le Gac, \& Persson, 2019a; Dominique Thierry, LeBozec, et al., 2019b). The referred associations have used 4 years tests for their calculations to argue this point, since 6 years tests were recently published.

According to Table 38 there are:

- 4 years test, that corresponds to test number 8

- 6 years test, that corresponds to test number 10

\subsubsection{Analysis on a 4-year test}

Table 49 contains all values for 4-year test. It also includes a calculation of the corrosion mass loss for the last 3 years and for the last 2 years.

Table 49: Ratio Z/ZM in 4 years field test (test number 8)

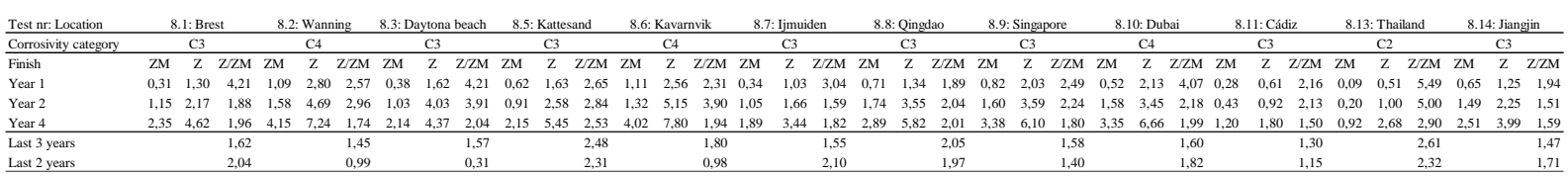

This is in order to see which is the corrosion result when removing the effect of year 1 and year 2. For instance, in the case of "Last 2 years" corrosion, this has been calculated, by subtracting the corrosion value of year 2 from the corrosion value of year 4. Below, we can find an example of how the calculation was performed, for the case of test number 8.1: Brest. Table 50 shows the values, extracted from Table 49 for this specific test:

Table 50: 4 years tests field results (example for test number 8.1: Brest)

\begin{tabular}{llll} 
Test nr: Location & \multicolumn{3}{l}{ 8.1: Brest } \\
\hline Corrosivity category & $\mathrm{C} 3$ & & \\
\hline Finish & $\mathrm{ZM}$ & $\mathrm{Z}$ & Z/ZM \\
\hline Year 1 & 0,31 & 1,30 & 4,21 \\
Year 2 & 1,15 & 2,17 & 1,88 \\
Year 4 & 2,35 & 4,62 & 1,96 \\
Last 3 years & & & 1,62 \\
Last 2 years & & & 2,04 \\
\hline
\end{tabular}

- Last 3 years:

$\mathbf{Z} / \mathbf{Z M}=($ Mass loss $\mathrm{Y} 4(\mathrm{Z})-$ Mass loss $\mathrm{Y} 1(\mathrm{Z}) /($ Mass loss $\mathrm{Y} 4(\mathrm{ZM})-$ Mass loss $\mathrm{Y} 1(\mathrm{ZM}))=(4,62-1,3) /(2,35-0,31)$ $=3,32 / 2,04=\mathbf{1 , 6 2}$

Last 2 years:

$\mathbf{Z} / \mathbf{Z M}=($ Mass loss $\mathrm{Y} 4(\mathrm{Z})-$ Mass loss $\mathrm{Y} 2(\mathrm{Z}) /($ Mass loss $\mathrm{Y} 4(\mathrm{ZM})-$ Mass loss $\mathrm{Y} 2(\mathrm{ZM}))=(4,62-2,17) /(2,35-1,15)$ $=2,45 / 1,2=\mathbf{2 , 0 4}$

Once explained the calculation method to remove the effect of the corrosion in the early years, it will be calculated the average of the ratio Z/ZM in each corrosivity class for each year. This calculation can be seen in Table 51: 
Table 51: Yearly evolution of Z/ZM average ratio for 4-years exposure test

\begin{tabular}{lrrrr}
\multicolumn{1}{c}{ Year } & $\begin{array}{c}\text { Z/ZM general } \\
\text { average }\end{array}$ & $\begin{array}{c}\text { Z/ZM average } \\
\text { C2 }\end{array}$ & $\begin{array}{c}\text { Z/ZM average } \\
\text { C3 }\end{array}$ & $\begin{array}{c}\text { Z/ZM average } \\
\text { C4 }\end{array}$ \\
\hline Year 1 & 3,09 & 5,49 & 2,82 & 2,98 \\
Year 2 & 2,68 & 5,00 & 2,27 & 3,01 \\
Year 4 & 1,99 & 2,90 & 1,91 & 1,89 \\
Last 3 years & 1,76 & 2,61 & 1,70 & 1,62 \\
Last 2 years & 1,59 & 2,32 & 1,62 & 1,26 \\
\hline
\end{tabular}

Figure 48 shows the yearly evolution of Z/ZM average ratio graphically:

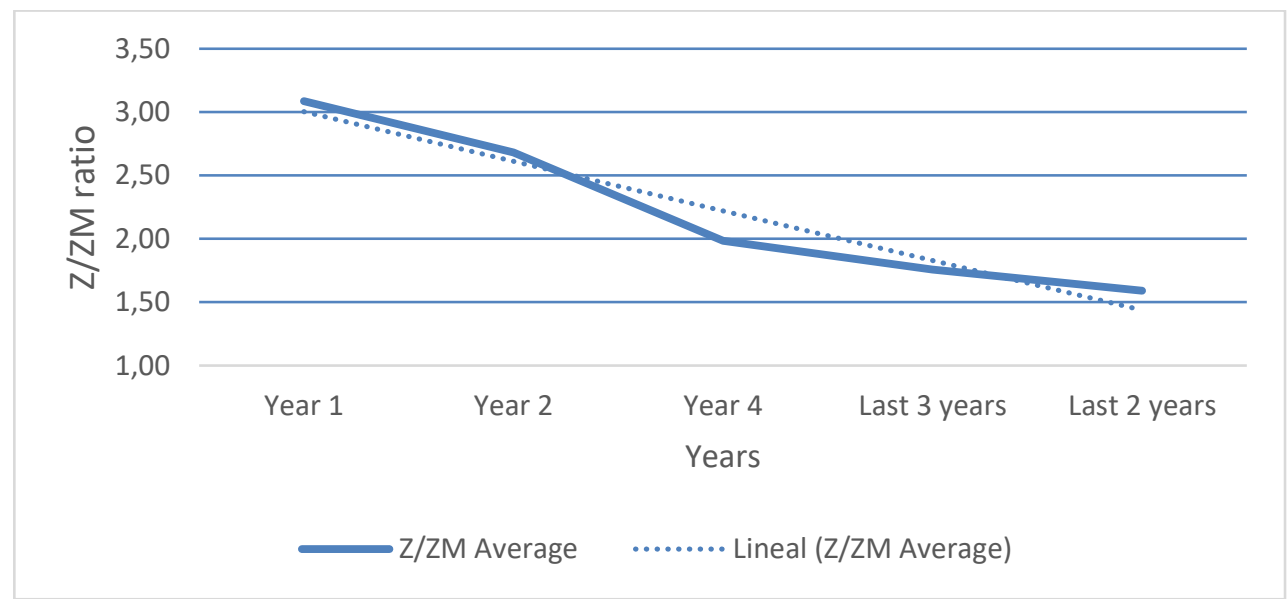

Figure 48: Yearly evolution of Z/ZM general average ratio for 4-years exposure test

The decreasing trend of the curve is evident, so, for this 4-years test seems to be reasonable the aforementioned arguments.

Let's see now the behaviour differentiating by corrosivity category:

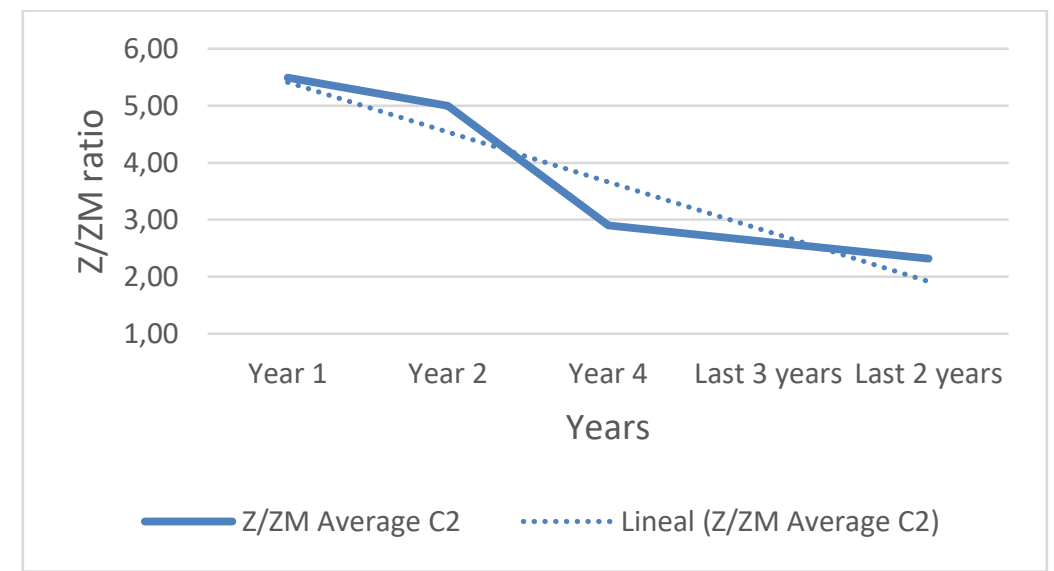

Figure 49: Yearly evolution of Z/ZM average ratio for 4-years exposure test - C2 corrosivity category 


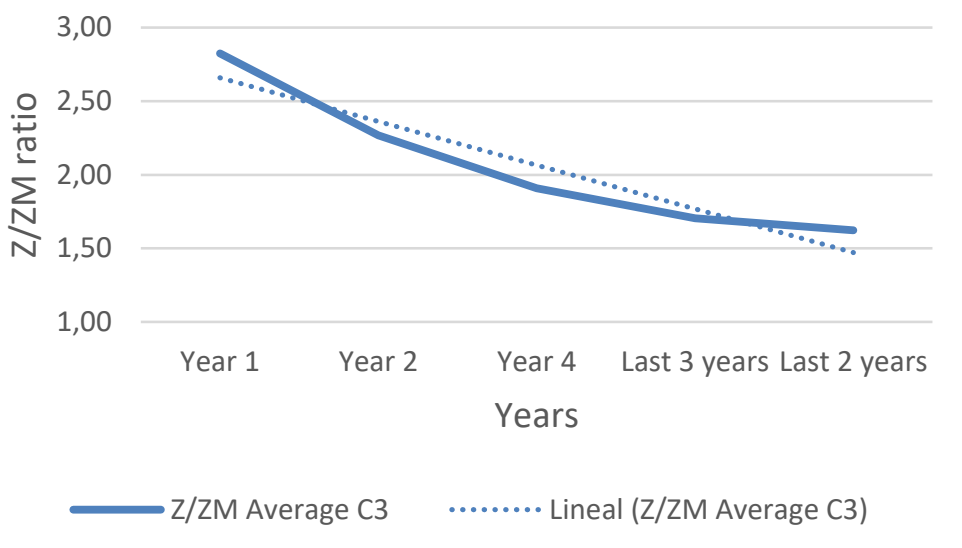

Figure 50: Yearly evolution of Z/ZM average ratio for 4-years exposure test - C3 corrosivity category

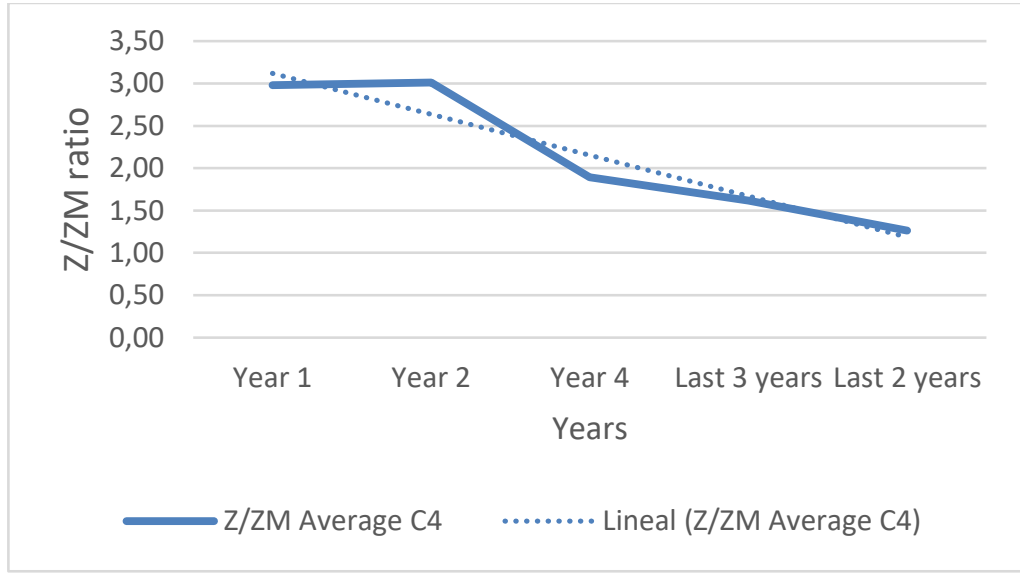

Figure 51: Yearly evolution of Z/ZM average ratio for 4-years exposure test - C4 corrosivity category

Therefore, it can be seen that the decreasing behaviour of the Z / ZM ratio occurs in all corrosivity categories. And as a second conclusion, the more it is subtracted the effect of the first years, the lower the corrosion in the last years is.

To conclude, it can be affirmed that the claims made by the aforementioned galvanizing associations are supported by the results of these 4-year tests. The following section will analyse whether the effect is the same in the 6 -year tests.

\subsubsection{Analysis on a 6-year test}

Table 52 contains all values for 6 years test. It also includes a calculation of the corrosion mass loss for the last 5 , 4 and 2 years.

Table 52: Ratio Z/ZM in 6 years field test (test number 10)

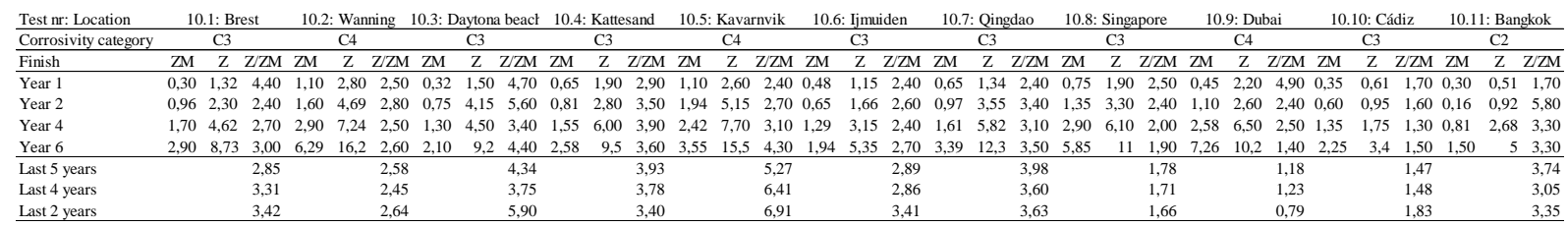

This is in order to see which is the corrosion result when removing the effect of year 1 , year 2 and year 4 . For instance, in the case of "Last 5 years" corrosion, this has been calculated, by subtracting the corrosion value of 
year 6 from the corrosion value of year 1. Below, we can find an example of how the calculation was performed, for the case of test number 10.1: Brest. Table 53 shows the values, extracted from Table 52 for this specific test:

Table 53: 6 years tests field results (test number 10.1: Brest)

\begin{tabular}{llll} 
Test nr: Location & \multicolumn{3}{l}{ 10.1: Brest } \\
\hline Corrosivity category & C3 & & \\
\hline Finish & ZM & Z & Z/ZM \\
\hline Year 1 & 0,30 & 1,32 & 4,4 \\
Year 2 & 0,96 & 2,30 & 2,40 \\
Year 4 & 1,70 & 4,62 & 2,70 \\
Year 6 & 2,90 & 8,73 & 3,00 \\
Last 5 years & & & 2,85 \\
Last 4 years & & & 3,31 \\
Last 2 years & & & 3,42 \\
\hline
\end{tabular}

- Last 5 years:

$\mathbf{Z} / \mathbf{Z M}=($ Mass loss Y6(Z)-Mass loss Y1(Z) / (Mass loss Y6(ZM)-Mass loss Y1(ZM)) = (8,73-1,32) / $(2,90-0,30)$ $=7,41 / 2,6=\mathbf{2 , 8 5}$

Last 4 years:

$\mathbf{Z} / \mathbf{Z M}=($ Mass loss Y6(Z)-Mass loss Y2(Z) / (Mass loss Y6(ZM)-Mass loss Y2(ZM)) = (8,73-2,30) / $(2,90-0,96)$ $=6,43 / 1,94=\mathbf{3 , 3 1}$

Last 2 years:

$\mathbf{Z} / \mathbf{Z M}=($ Mass loss Y6(Z)-Mass loss Y4(Z) / (Mass loss Y6(ZM)-Mass loss Y4(ZM)) = (8,73-4,62) / (2,90-1,70) $=4,11 / 1,2=\mathbf{3 , 4 2}$

Once explained the calculation method to remove the effect of the corrosion in the early years, it will be calculated the average of the ratio Z/ZM for each year. This calculation can be seen in Table 54:

Table 54: Yearly evolution of Z/ZM average ratio for 6-years exposure test

\begin{tabular}{lrrrr}
\multicolumn{1}{c}{ Year } & $\begin{array}{c}\text { Z/ZM Average } \\
\text { General }\end{array}$ & $\begin{array}{c}\text { Z/ZM average } \\
\text { C2 }\end{array}$ & $\begin{array}{c}\text { Z/ZM average } \\
\text { C3 }\end{array}$ & $\begin{array}{c}\text { Z/ZM average } \\
\text { C4 }\end{array}$ \\
\hline Year 1 & 2,95 & 1,70 & 3,00 & 3,27 \\
Year 2 & 3,20 & 5,80 & 3,07 & 2,63 \\
Year 4 & 2,75 & 3,30 & 2,69 & 2,70 \\
Year 6 & 2,93 & 3,30 & 2,94 & 2,77 \\
Last 5 years & 3,09 & 3,74 & 3,03 & 3,01 \\
Last 4 years & 3,06 & 3,05 & 2,93 & 3,37 \\
Last 2 years & 3,36 & 3,35 & 3,32 & 3,45 \\
\hline
\end{tabular}

Figure 52 shows the yearly evolution of Z/ZM average ratio graphically: 


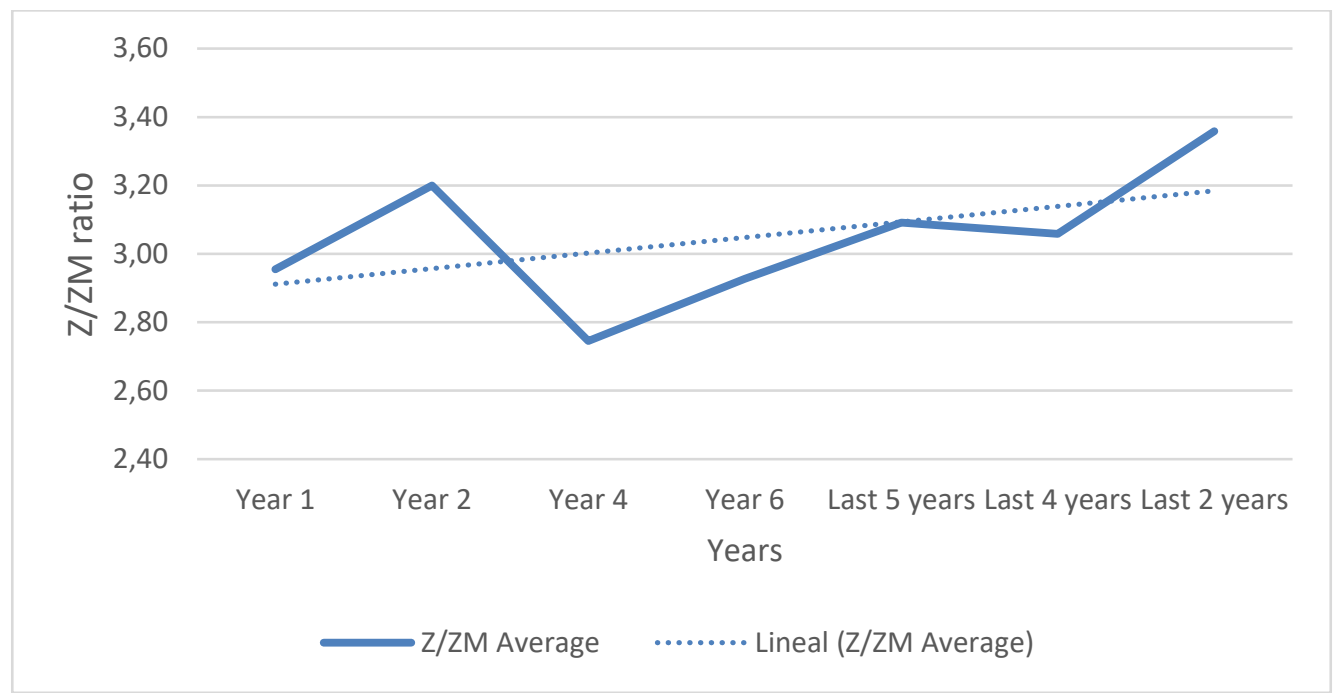

Figure 52: Yearly evolution of Z/ZM general average ratio for 6-years exposure test

The rising trend of the chart is evident. The trend line clearly shows this rising behaviour so, for this 6-years test the fact of subtracting the effect of the corrosion in the first years, is not affecting the rising trend of the ratio. In other words, seems to be no correlation between Z/ZM ratio and the corrosion during the first years of exposure. Let's see now the behaviour differentiating by corrosivity category:

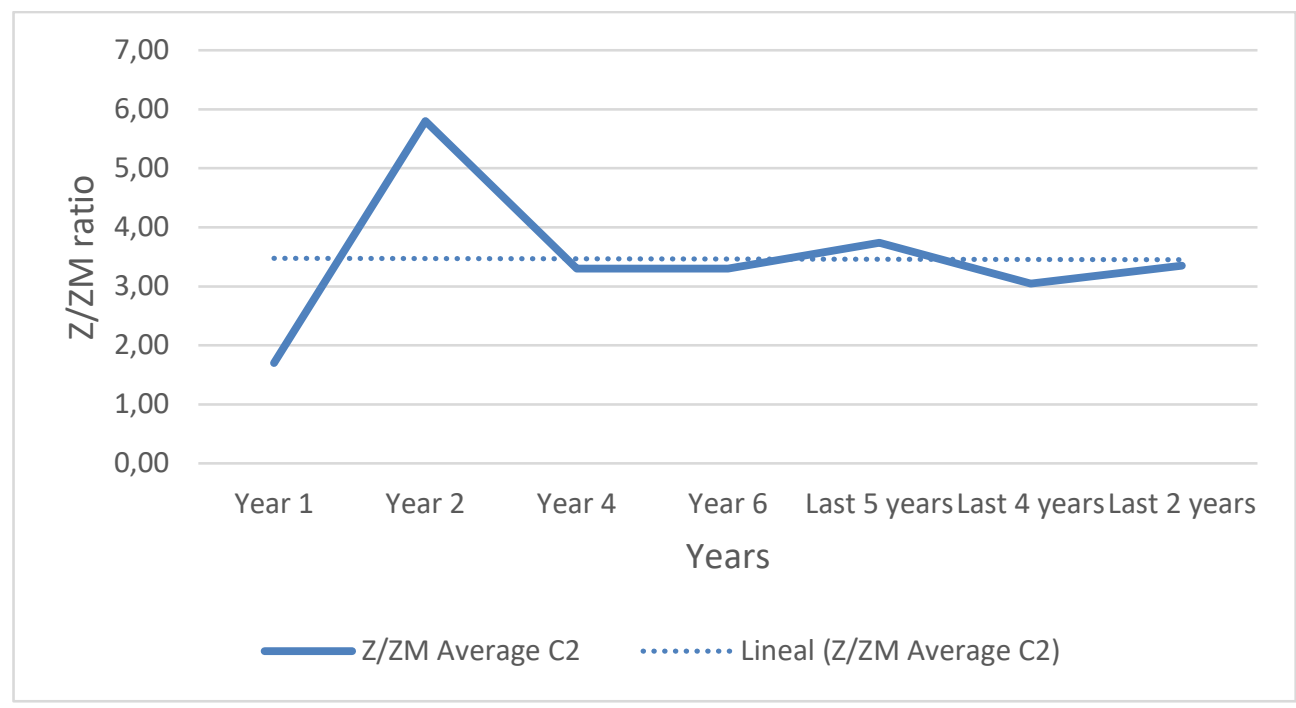

Figure 53: Yearly evolution of Z/ZM average ratio for 6-years exposure test - C2 corrosivity category 


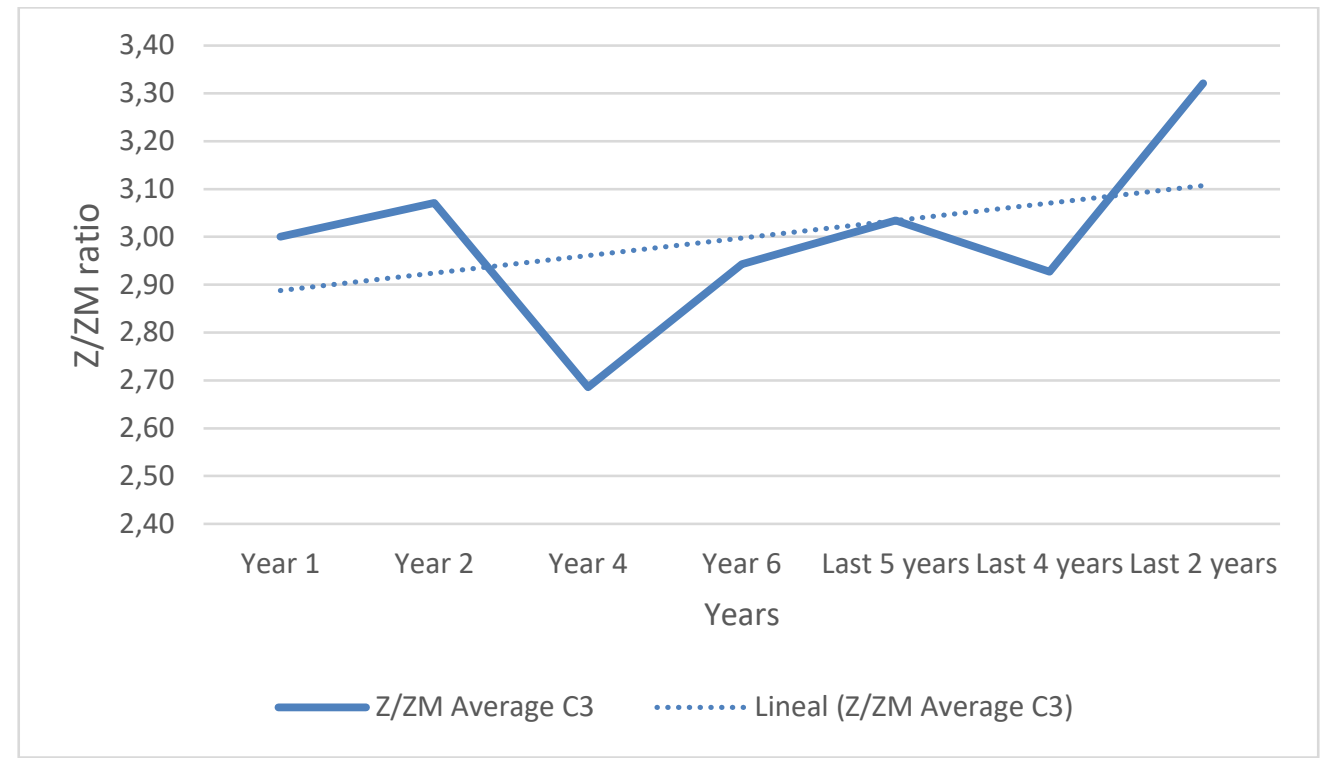

Figure 54: Yearly evolution of Z/ZM average ratio for 6-years exposure test - C3 corrosivity category

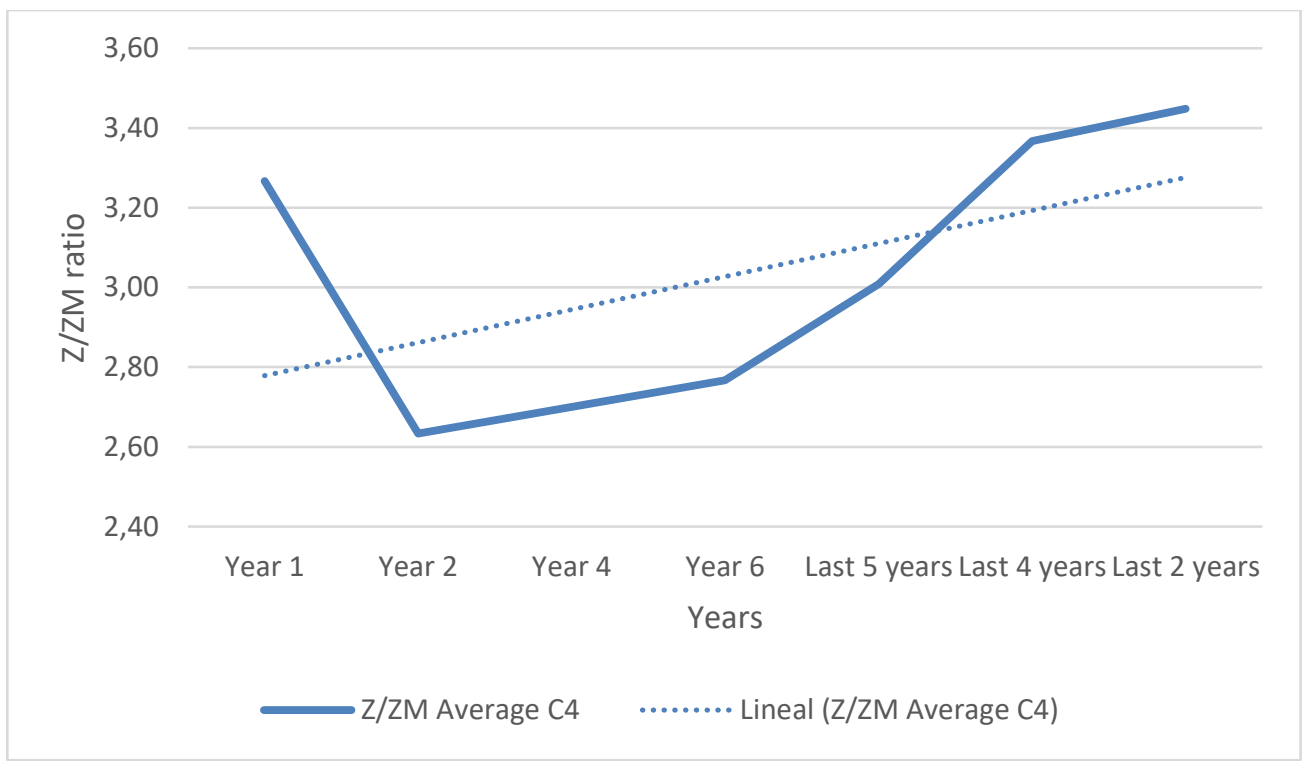

Figure 55: Yearly evolution of Z/ZM average ratio for 6-years exposure test - C4 corrosivity category

Looking at the charts, with the exception of $\mathrm{C} 2$ corrosivity category, which seems to keep a flat trend line, for $\mathrm{C} 3$ and $\mathrm{C} 4$ the effect is almost the contrary, i.e., there's a clear pronounced rising trend line.

Therefore, unfortunately is not possible to take a consistent conclusion looking at 4-years tests and 6-years tests. There's no consistency in the results and a further analysis shall be done when having more field tests results.

\subsection{Cut edges effect}

The effect of the non-protected surfaces in ZM finishes, mainly cut edges, has been an important point of discussion. On one hand, hot dip galvanizers claimed that this are clearly weak points of ZM coatings and on the other hand, ZM manufacturers claims that these parts of the components have a type of self-healing protection. For instance, Arcelor Mittal, one of the most important ZM manufacturers through is brand Magnelis ${ }^{\circledR}$ has a big amount of literature to defend this self-healing characteristic (Arcelor Mittal, 2013e, 2017, 2018; R\&D, 2015). This particular manufacturer argues that in conditions of exposure to the environment, Magnelis ${ }^{\circledR}$ forms a very 
dense zinc-based protective patina, unlike the porous galvanized film. This very unique dense layer is also formed on the edges, welds, punctures and scratches, so in case that in these uncoated areas some red oxide, this would be gradually covered by the Magnelis ${ }^{\circledR}$ layer. It is almost impossible for the environment to pass through this patina, which is why Magnelis ${ }^{\circledR}$ offers perfect protection of the entire structure, including the uncoated edges, scratches and perforations.

For their part, hot dip galvanized manufacturers have a completely different view. According to them (Rus, 2019), cut edges used in the in outdoor exposure testing are generally protected either by tape or by paint. This testing method avoids any effect of cut edges on the corrosion of the test panel - which is a significant departure from reality for many steel products where ZM coatings may be used. This important effect has been shown in a fiveyear atmospheric exposure study conducted in Japan. Shibayama and Takedomi (Shibayama \& Takedomi, 2015) presented the significant difference in corrosion performance when measured with painting of the cut edges and without such painting, raising the question of the actual relevance of atmospheric exposure data in case of continuously coated steel, where cut edges are a reality and testing done with protected cut edges doesn't seem to reflect it.

In their study of corrosion of ZM coatings in a marine environment, Tomandl and Labrenz (Tomandl \& Labrenz, 2016) observed that ZM coatings adjacent to cut edges were completely consumed within three years at a test site in China and just one year at a test site in Mexico. The authors of this paper concluded that on specimens with a thickness of $2 \mathrm{~mm}$, cathodic protection at the cut edges no longer exists after conversion of the layer 2-3mm away from the edge and that according to this evaluation, long-term protection at the cut edges is to be expected only on the specimens from the location with the lowest corrosivity.

To conclude, and as a regard this thesis, it is important to highlight that:

- All field tests analysed in previous clauses have been arranged considering the mass loss measured and with plane samples, avoiding / protecting the cutted surfaces of the samples tested.

- $\quad$ Because of this, the point of the behaviour of corrosion on cut edges can be an important point to take for future investigations.

\subsection{Long-term corrosion prediction}

\subsubsection{Corrosion prediction with the actual field tests values analysis}

According to the previous clauses, it is possible to make a reliable corrosion prediction with the analysed data with certain accuracy in these cases:

- $\quad$ For C2, C3, C4, C5 and CX corrosivity category

- $\quad$ Up to 6-years prediction for $\mathrm{C} 2, \mathrm{C} 3$ and $\mathrm{C} 4$

- Up to 2-years prediction for C5 and CX

There will be a certain margin of error, since it is based in statistic values, coming from the field tests that have been analysed. For this purpose, the engineer can take the average and standard deviation reference values given in Table 41: Average, median and standard deviation from field tests for ZM finishes, but also can take a valuable information from boxplot charts given in Figure 29, Figure 30, Figure 31, Figure 32 and Figure 33. These charts offer most of the information needed to make calculations about the average duration of the coating, which could be the best and the worst case and other type of statistic information such as:

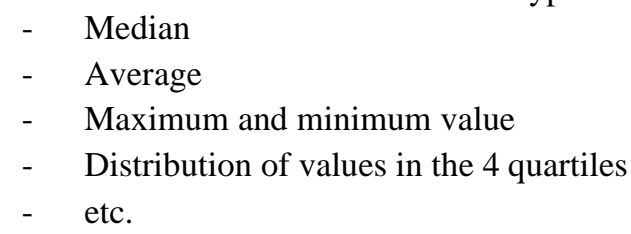

This information can lead to calculate not only the duration of the coating but also, on the other way around, how much thickness would it be needed to withstand corrosion for a certain period of time. In the same way, this is also needed to evaluate the cost of the coating, based in the amount of alloy needed (normally $\mathrm{g} / \mathrm{m}^{2}$ ).

Unfortunately, as it was mentioned before, the limited number of existing field tests, makes these calculations only possible, in the best of the cases, for 6 years prediction for $\mathrm{C} 2, \mathrm{C} 3$ and $\mathrm{C} 4$. Thus, it is needed to complement this research work when having more real field tests, in order to have a mathematical model that, in a more precise way, can simulate the behaviour of corrosion in the medium and long term. 


\subsubsection{Corrosion prediction using the general corrosion expression}

According to what was said in the clause Background, based in several studies (CEN, 2012; Chenoll-Mora et al., 2018; Feliu Batlle et al., 1993a; González Fernández, 1984; Pourbaix, 1982b), the corrosion, in most of the cases, is estimated by means of bi-logarithmic expressions of the type of Equation 1:

$$
C(t)=A \cdot t^{n}
$$

(Equation 1)

where,

- $\quad C(t)$ is the accumulated corrosion at year $t$.

- $A$ is the corrosion at first year of exposure.

- $\quad n$ is a constant, which depends on each metal and the particular atmospheric condition (Morcillo, 1998); generally, $n<1$.

- $\quad t$ is the time in years.

This expression comes from the principle that the corrosion process has not a linear behaviour, because over time, appear the so-called corrosion products that gives an over-protection and slow down this process. This effect is mathematically taken into consideration in the expression through the constant $n$, which depends also on the atmospheric characteristics of the environment. There is big deal of literature about $n$ parameter(CEN, 2012; Chico et al., 2010; Dean \& Reiser, 2002; Hernández et al., 2002; Knotkova et al., 1995, 2010; Morcillo, 1998; Panchenko et al., 2014; Pourbaix, 1982a). Based on those references, for the case of zinc, it is commonly accepted that $n$ parameter is usually in the range of 0,8 to 1 .

\subsubsection{Application of long-term corrosion prediction to $\mathrm{ZM}$ alloys with general corrosion expression}

Considering that the corrosion process of ZM alloys can follow the general corrosion expression referred in the previous clause, now it will be calculated such expression by means of the values obtained from the field tests.

Corrosion function will be determined for each corrosivity category, by applying Equation 1 . These are the steps followed for the determination:

a) Identify yearly corrosion for the first year of exposure (parameter $A$ ).

It will be estimated as the average of the different corrosion values in the field tests done for this first year of exposure (Table 41).

b) Identify corrosion for the second year of exposure

It will be estimated as the average of the different corrosion values in the field tests done for this second year of exposure (Table 41).

c) Calculate $n$ parameter

Substitute $C$ (2) and $A$ in Equation 1 and clear $n$ parameter.

d) Determine the long-term corrosion function

Substitute $n$ and $A$ parameters in Equation 1.

According to this methodology, it will be determined for each corrosivity category this long-term corrosion function:

Corrosivity category $\mathrm{C} 2-$ Year 2

a) Corrosion at first year of exposure: $A$. This is calculated as the average of the recorded values for Y1 (Table 41). So, $A=0,2 \mu \mathrm{m}$.

b) Corrosion at second year of exposure. This is calculated as the average of the recorded values for Y2 (Table 41). It corresponds to $0,34 \mu \mathrm{m}$.

c) Substituting $C(2)$ and $A$ in Equation $1, n$ can be cleared: $C(t)=A \cdot t^{n} ; C(2)=\mathrm{A} \cdot 2^{n} ; 0,34=0,2 \cdot 2^{n} ; 2^{n}=1,7 ; \mathrm{n}=\log 1,7 / \log 2=0,745$

d) The long-term corrosion expression for $\mathrm{ZM}$ alloys in $\mathrm{C} 3$ environments is determined by:

$$
\mathrm{C}(\mathrm{t})=0,2 \cdot \mathrm{t}^{0,745}
$$

Same methodology has been used for the rest of the corrosivity categories, which leads to Table 55 where the calculation of all parameters can be found, as well as the long-term corrosion expression for each of the corrosivity categories and year. As can be seen, inside each corrosivity category there is a different value of $n$ constant for each year, that is the reason why it has also been calculated the average value of $n$ for each corrosivity category (field "Average"), so to have a common $n$ value for the prediction. Based in this average value of $n$, the correspondent logarithmic corrosion expression has been determined. This expression, based in the average value 
of $n$, will be the one used to estimate the long-term corrosion when it comes to periods above 6 years. The use of this methodology implies an error on the calculation, when comparing this average value with the values given by solving long-term corrosion for the rest of the $n$ constant values. In this regard, Table 55 shows 2 values: (1) The difference between the corrosion value for each $n$ individual value and the forecasted corrosion value (using the average of $n$ ); (2) The error of this difference, calculated in percentage.

Table 55: Corrosion parameters using logarithmic method. Forecasted values

\begin{tabular}{|c|c|c|c|c|c|c|c|}
\hline $\begin{array}{l}\text { Corrosivity } \\
\text { category }\end{array}$ & Year & $\mathrm{C}(\mu \mathrm{m})$ & $\mathrm{n}$ & $\begin{array}{l}\text { Logarithmic } \\
\text { expression }\end{array}$ & $\begin{array}{l}\text { Cforecasted } \\
(\mu \mathrm{m})\end{array}$ & $\begin{array}{c}\mathrm{C}-\mathrm{C}_{\text {forecasted }} \\
(\mu \mathrm{m})\end{array}$ & Error \\
\hline \multirow{5}{*}{ C2 - Low } & 1 & 0,202 & - & - & 0,202 & 0,000 & $0,000 \%$ \\
\hline & 2 & 0,339 & 0,745 & $\mathrm{C}(\mathrm{t})=0,202 * \mathrm{t}^{0,745}$ & 0,395 & $-0,056$ & $-16,376 \%$ \\
\hline & 4 & 0,865 & 1,047 & $\mathrm{C}(\mathrm{t})=0,202 * \mathrm{t}^{1,047}$ & 0,770 & 0,094 & $12,248 \%$ \\
\hline & 6 & 1,452 & 1,099 & $\mathrm{C}(\mathrm{t})=0,202 * \mathrm{t}^{1,099}$ & 1,139 & 0,313 & $27,467 \%$ \\
\hline & Average & - & 0,964 & $\mathrm{C}(\mathrm{t})=0,202 * \mathrm{t}^{0,964}$ & - & 0,088 & $7,780 \%$ \\
\hline \multirow{5}{*}{ C3 - Medium } & 1 & 0,572 & - & - & 0,572 & 0,000 & $0,000 \%$ \\
\hline & 2 & 0,994 & 0,798 & $\mathrm{C}(\mathrm{t})=0,572 * \mathrm{t}^{0,798}$ & 1,027 & $-0,032$ & $-3,237 \%$ \\
\hline & 4 & 2,023 & 0,911 & $\mathrm{C}(\mathrm{t})=0,572 * \mathrm{t}^{0,911}$ & 1,843 & 0,179 & $9,736 \%$ \\
\hline & 6 & 2,500 & 0,823 & $C(t)=0,572 * t^{0,823}$ & 2,596 & $-0,096$ & $-3,844 \%$ \\
\hline & Average & - & 0,844 & $\mathrm{C}(\mathrm{t})=0,572 * \mathrm{t}^{0,844}$ & - & 0,013 & $\mathbf{0 , 8 8 5 \%}$ \\
\hline \multirow{5}{*}{ C4 - High } & 1 & 1,001 & - & - & 1,001 & 0,000 & $0,000 \%$ \\
\hline & 2 & 1,344 & 0,425 & $\mathrm{C}(\mathrm{t})=1,001 * \mathrm{t}^{0,425}$ & 1,667 & $-0,323$ & $-23,996 \%$ \\
\hline & 4 & 3,081 & 0,811 & $\mathrm{C}(\mathrm{t})=1,001 * \mathrm{t}^{0,811}$ & 2,776 & 0,305 & $10,992 \%$ \\
\hline & 6 & 5,699 & 0,971 & $\mathrm{C}(\mathrm{t})=1,001 * \mathrm{t}^{0,971}$ & 3,740 & 1,959 & $52,376 \%$ \\
\hline & Average & - & 0,736 & $\mathrm{C}(\mathrm{t})=1,001 * \mathrm{t}^{0,736}$ & - & 0,485 & $13,124 \%$ \\
\hline \multirow{3}{*}{ C5 - Very high } & 1 & 3,267 & - & - & 3,267 & 0,000 & $0,000 \%$ \\
\hline & 2 & 9,200 & 1,494 & $C(t)=3,267 * t^{1,494}$ & 9,200 & 0,000 & $0,000 \%$ \\
\hline & Average & - & 1,494 & $\mathrm{C}(\mathrm{t})=3,267 * \mathrm{t}^{1,494}$ & - & 0,000 & $0,000 \%$ \\
\hline \multirow{3}{*}{ CX - Extreme } & 1 & 6,225 & - & - & 6,225 & 0,000 & $0,000 \%$ \\
\hline & 2 & 12,800 & 1,040 & $C(t)=6,225 * t^{1,040}$ & 12,800 & 0,000 & $0,000 \%$ \\
\hline & Average & - & 1,040 & $C(t)=6,225 * t^{1,040}$ & - & 0,000 & $0,000 \%$ \\
\hline
\end{tabular}

Now, it will be analysed in detail Table 55 for each corrosivity category, besides the table of values of the corrosion evolution based in the long-term logarithmic expressions determined and its correspondent graphic representation.

a) C2 corrosivity category

Table 56 shows the values of mass loss for $\mathrm{C} 2$ corrosivity category and for each year, by solving the following functions referred in Table 55, from year 1 to year 30:

Equation 14: Corrosion function for C2 corrosivity category-Year 2

$$
C(t)=0,202 * t^{0,745}(\text { for year } 2)
$$

Equation 15: Corrosion function for $\mathrm{C} 2$ corrosivity category-Year 4

$$
C(t)=0,202 * t^{1,047}(\text { for year } 4)
$$


Equation 16: Corrosion function for C2 corrosivity category-Year 6

$$
\mathrm{C}(\mathrm{t})=0,202 * \mathrm{t}^{1,099} \text { (for year } 6 \text { ) }
$$

Equation 17: Corrosion function for $\mathrm{C} 2$ corrosivity category-Average

$$
\mathrm{C}(\mathrm{t})=0,202 * \mathrm{t}^{0,964} \text { (with } n \text { average of year 2, } 4 \text { and } 6 \text { ) }
$$

\begin{tabular}{|c|c|c|c|c|}
\hline \multirow{2}{*}{ Year } & \multicolumn{4}{|c|}{ Mass loss $(\mu \mathrm{m})-\mathrm{C} 2$ corrosivity category } \\
\hline & $\mathrm{n}(\mathrm{Y} 2)$ & $\mathrm{n}(\mathrm{Y} 4)$ & n (Y6) & $\mathrm{n}$ average \\
\hline 1 & 0,202 & 0,202 & 0,202 & 0,202 \\
\hline 2 & $\mathbf{0 , 3 3 9}$ & 0,418 & 0,434 & 0,395 \\
\hline 3 & 0,459 & 0,640 & 0,678 & 0,584 \\
\hline 4 & 0,569 & 0,865 & 0,930 & 0,770 \\
\hline 5 & 0,672 & 1,092 & 1,188 & 0,955 \\
\hline 6 & 0,769 & 1,322 & 1,452 & 1,139 \\
\hline 7 & 0,863 & 1,554 & 1,720 & 1,321 \\
\hline 8 & 0,953 & 1,787 & 1,992 & 1,503 \\
\hline 9 & 1,041 & 2,022 & 2,267 & 1,683 \\
\hline 10 & 1,126 & 2,258 & 2,545 & 1,863 \\
\hline 11 & 1,209 & 2,495 & 2,826 & 2,043 \\
\hline 12 & 1,290 & 2,733 & 3,110 & 2,221 \\
\hline 13 & 1,369 & 2,971 & 3,396 & 2,400 \\
\hline 14 & 1,447 & 3,211 & 3,685 & 2,577 \\
\hline 15 & 1,523 & 3,452 & 3,975 & 2,754 \\
\hline 16 & 1,598 & 3,693 & 4,267 & 2,931 \\
\hline 17 & 1,672 & 3,935 & 4,561 & 3,108 \\
\hline 18 & 1,745 & 4,178 & 4,857 & 3,284 \\
\hline 19 & 1,816 & 4,422 & 5,155 & 3,459 \\
\hline 20 & 1,887 & 4,666 & 5,454 & 3,635 \\
\hline 21 & 1,957 & 4,910 & 5,754 & 3,810 \\
\hline 22 & 2,026 & 5,155 & 6,056 & 3,984 \\
\hline 23 & 2,094 & 5,401 & 6,359 & 4,159 \\
\hline 24 & 2,162 & 5,647 & 6,664 & 4,333 \\
\hline 25 & 2,229 & 5,894 & 6,970 & 4,507 \\
\hline 26 & 2,295 & 6,141 & 7,277 & 4,681 \\
\hline 27 & 2,360 & 6,388 & 7,585 & 4,854 \\
\hline 28 & 2,425 & 6,636 & 7,895 & 5,027 \\
\hline 29 & 2,489 & 6,885 & 8,205 & 5,200 \\
\hline 30 & 2,553 & 7,134 & 8,517 & 5,373 \\
\hline
\end{tabular}

Table 56: Yearly mass loss evolution in C2 corrosivity category for each of the calculated values of $n$

On the other hand, Figure 56 shows the graphic evolution of each of these functions, in order to have a clearer view of what its evolution is: 


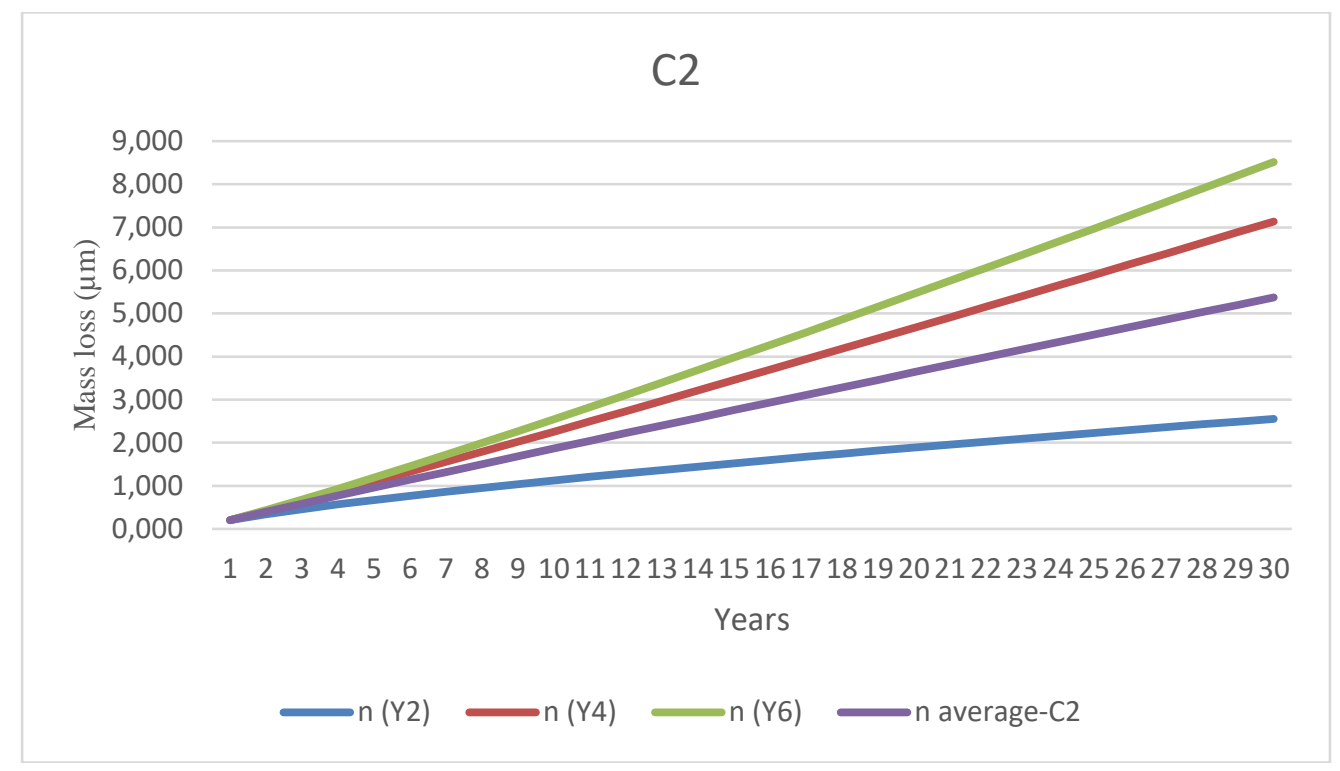

Figure 56: Yearly mass loss graphic evolution in C2 corrosivity category for each of the calculated values of $n$

It is important to highlight that in Equation 15 and Equation $16 n$ values are greater than 1 . According to the general corrosion expression (Equation 1) $n$ values should be less than 1, in order to consider the protection of corrosion products along the time. In this case, it is important to consider that the values had for year 4 and 6 in $\mathrm{C} 2$ corrosivity category (see Table 40) are very little: 2 values $(0,92$ and 0,81$)$ for Year 4 and just 1 value $(1,45)$ for Year 6 . Thus, these equations shall be taken carefully at the time of making long-term predictions, and they must be completed in future researches that complement this thesis with additional field tests. For this reason, in this case, it is more reasonable to use Equation 17 (average) for long-term predictions in order to avoid the use of equations obtained with such low number of statistical values.

This fact is also reflected in the field of "Error" in Table 55: while the average error is 7,780\%, the error for Year 6 is $27,467 \%$, which also reflect the lack of statistical values, translated in an important error of the prediction calculation.

For year 1 and year 2 there are more statistical values, so, calculations are more accurate. For the specific case of year 2 (Equation 14) the value of $n$ is less than 1 and this behaviour es clearly reflected in Figure 56, that matches with a typical behaviour of a corrosion function, with an exponential negative behaviour.

Finally, it is important to highlight that the lower error $(7,780 \%)$ is obtained with the average value of $n(0,964)$, thus, despite all previous considerations, this should be the value to be taken to calculated long-term corrosion.

b) C3 corrosivity category

Table 57 shows the values of mass loss for C3 corrosivity category and for each year, by solving the following functions referred in Table 55, from year 1 to year 30:

Equation 18: Corrosion function for C3 corrosivity category-Year 2

$$
\mathrm{C}(\mathrm{t})=0,572 * \mathrm{t}^{0,798}
$$

Equation 19: Corrosion function for C3 corrosivity category-Year 4

$$
\mathrm{C}(\mathrm{t})=0,572 * \mathrm{t}^{0,911}
$$

Equation 20: Corrosion function for C3 corrosivity category-Year 6

$$
C(t)=0,572 * t^{0,823}
$$

Equation 21: Corrosion function for $\mathrm{C} 3$ corrosivity category-Average

$$
\mathrm{C}(\mathrm{t})=0,572 * \mathrm{t}^{0,844}
$$


Table 57: Yearly mass loss evolution in C3 corrosivity category for each of the calculated values of $n$

\begin{tabular}{|c|c|c|c|c|}
\hline \multirow{2}{*}{ Year } & \multicolumn{4}{|c|}{ Mass loss $(\mu \mathrm{m})-\mathrm{C} 3$ corrosivity category } \\
\hline & $\mathrm{n}(\mathrm{Y} 2)$ & $\mathrm{n}(\mathrm{Y} 4)$ & n (Y6) & $\mathrm{n}$ average \\
\hline 1 & 0,572 & 0,572 & 0,572 & 0,572 \\
\hline 2 & 0,994 & 1,075 & 1,012 & 1,027 \\
\hline 3 & 1,375 & 1,556 & 1,413 & 1,446 \\
\hline 4 & 1,730 & 2,023 & 1,790 & 1,843 \\
\hline 5 & 2,067 & 2,479 & 2,152 & 2,226 \\
\hline 6 & 2,391 & 2,927 & 2,500 & 2,596 \\
\hline 7 & 2,704 & 3,369 & 2,838 & 2,957 \\
\hline 8 & 3,008 & 3,805 & 3,168 & 3,310 \\
\hline 9 & 3,305 & 4,236 & 3,491 & 3,656 \\
\hline 10 & 3,595 & 4,663 & 3,807 & 3,996 \\
\hline 11 & 3,879 & 5,086 & 4,118 & 4,331 \\
\hline 12 & 4,158 & 5,506 & 4,424 & 4,662 \\
\hline 13 & 4,433 & 5,923 & 4,725 & 4,988 \\
\hline 14 & 4,703 & 6,337 & 5,023 & 5,310 \\
\hline 15 & 4,969 & 6,748 & 5,316 & 5,628 \\
\hline 16 & 5,232 & 7,157 & 5,606 & 5,943 \\
\hline 17 & 5,492 & 7,564 & 5,893 & 6,256 \\
\hline 18 & 5,748 & 7,968 & 6,177 & 6,565 \\
\hline 19 & 6,002 & 8,371 & 6,459 & 6,872 \\
\hline 20 & 6,253 & 8,771 & 6,737 & 7,176 \\
\hline 21 & 6,501 & 9,170 & 7,013 & 7,478 \\
\hline 22 & 6,747 & 9,567 & 7,287 & 7,777 \\
\hline 23 & 6,991 & 9,963 & 7,559 & 8,075 \\
\hline 24 & 7,233 & 10,357 & 7,829 & 8,370 \\
\hline 25 & 7,472 & 10,750 & 8,096 & 8,664 \\
\hline 26 & 7,710 & 11,141 & 8,362 & 8,956 \\
\hline 27 & 7,946 & 11,531 & 8,626 & 9,246 \\
\hline 28 & 8,180 & 11,919 & 8,888 & 9,534 \\
\hline 29 & 8,412 & 12,307 & 9,149 & 9,821 \\
\hline 30 & 8,643 & 12,693 & 9,408 & 10,106 \\
\hline
\end{tabular}

On the other hand, Figure 57 shows the graphic evolution of each of these functions, in order to have a clearer view of what its evolution is: 


\section{C3}

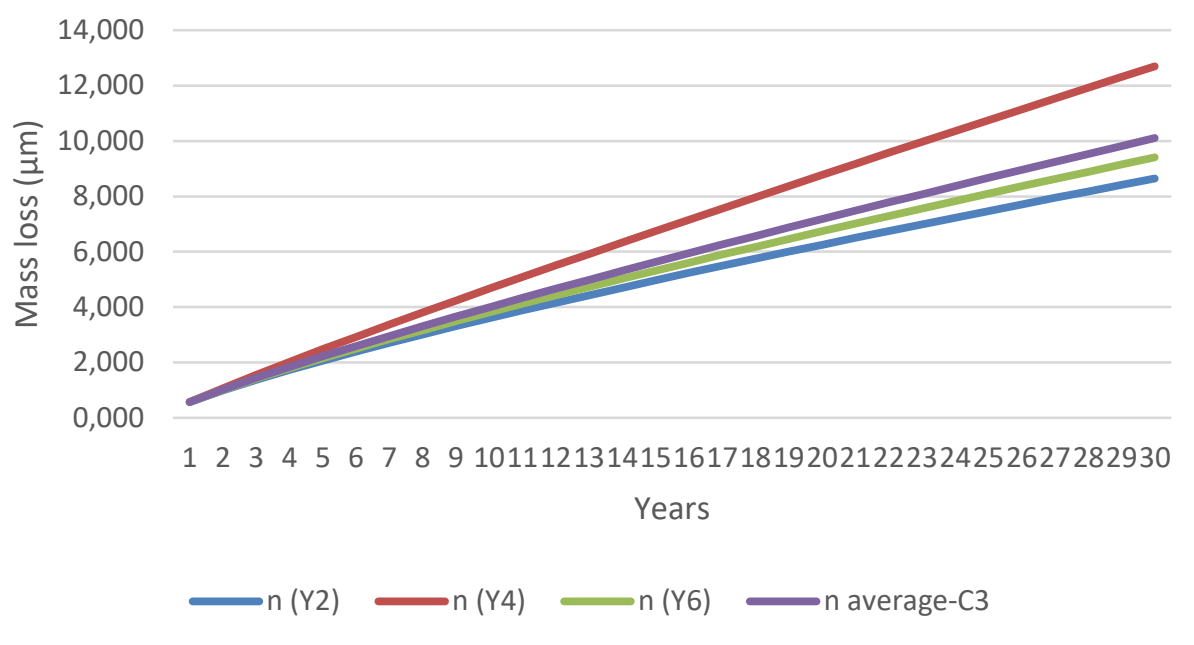

Figure 57: Yearly mass loss graphic evolution in C3 corrosivity category for each of the calculated values of $n$

Unlike what happened in C2 corrosivity category, for C3 corrosivity category, all the values of $n$ in Equation 18 to Equation 21 are less than 1. Since there are much more statistical values in this $\mathrm{C} 3$ corrosivity categories, all the parameters are much more consistent, not only for the $n$ values, but also for instance for the values of error in Table 55, where it is reflected that the average error is $0,885 \%$ and there is a maximum error of $9,736 \%$ in $\mathrm{Y} 4$. That's why, as it was said in the previous analysis of C2 category, the number of statistical values is crucial to get a reliable calculation. C3 corrosivity category is the one with the higher number of values in all corrosivity categories and that's why it is also the one having the lower level of error in all the analysed years, as well, as the average. Finally, Figure 57 is showing very clearly this effect. It can be seen how the different corrosion curves are very closed to each other, showing that the error is drastically reduced when comparing to the rest of the corrosivity categories. In other words, the predictions calculated for $\mathrm{C} 3$ corrosivity category will be the most accurate of all the rest of corrosivity categories.

Finally, it is important to highlight that the lower error $(0,885 \%)$ is obtained with the average value of $n(0,844)$, thus, despite all previous considerations, this should be the value to be taken to calculated long-term corrosion.

c) C4 corrosivity category

Table 58 shows the values of mass loss for $\mathrm{C} 4$ corrosivity category and for each year, by solving the following functions referred in Table 55, from year 1 to year 30:

Equation 22: Corrosion function for C4 corrosivity category-Year 2

$$
\mathrm{C}(\mathrm{t})=1,001 * \mathrm{t}^{0,425}
$$

Equation 23: Corrosion function for $\mathrm{C} 4$ corrosivity category-Year 4

$$
\mathrm{C}(\mathrm{t})=1,001 * \mathrm{t}^{0,811}
$$

Equation 24: Corrosion function for C4 corrosivity category-Year 6

$$
\mathrm{C}(\mathrm{t})=1,001 * \mathrm{t}^{0,971}
$$

Equation 25: Corrosion function for C4 corrosivity category-Average

$$
\mathrm{C}(\mathrm{t})=1,001 * \mathrm{t}^{0,736}
$$


Table 58: Yearly mass loss evolution in C4 corrosivity category for each of the calculated values of $n$

\begin{tabular}{|c|c|c|c|c|}
\hline \multirow{2}{*}{ Year } & \multicolumn{4}{|c|}{ Mass loss $(\mu \mathrm{m})-\mathrm{C} 4$ corrosivity category } \\
\hline & $\mathrm{n}(\mathrm{Y} 2)$ & n (Y4) & n (Y6) & $\mathrm{n}$ average \\
\hline 1 & 1,001 & 1,001 & 1,001 & 1,001 \\
\hline 2 & 1,344 & 1,756 & 1,962 & 1,667 \\
\hline 3 & 1,597 & 2,440 & 2,908 & 2,246 \\
\hline 4 & 1,805 & 3,081 & 3,845 & 2,776 \\
\hline 5 & 1,985 & 3,692 & 4,775 & 3,271 \\
\hline 6 & 2,145 & 4,280 & 5,699 & 3,740 \\
\hline 7 & 2,290 & 4,849 & 6,619 & 4,189 \\
\hline 8 & 2,424 & 5,404 & 7,535 & 4,621 \\
\hline 9 & 2,549 & 5,945 & 8,447 & 5,040 \\
\hline 10 & 2,665 & 6,476 & 9,357 & 5,446 \\
\hline 11 & 2,776 & 6,996 & 10,263 & 5,841 \\
\hline 12 & 2,880 & 7,507 & 11,168 & 6,227 \\
\hline 13 & 2,980 & 8,010 & 12,070 & 6,605 \\
\hline 14 & 3,075 & 8,506 & 12,970 & 6,975 \\
\hline 15 & 3,167 & 8,996 & 13,869 & 7,338 \\
\hline 16 & 3,255 & 9,479 & 14,765 & 7,695 \\
\hline 17 & 3,340 & 9,957 & 15,660 & 8,045 \\
\hline 18 & 3,422 & 10,429 & 16,553 & 8,391 \\
\hline 19 & 3,502 & 10,896 & 17,445 & 8,731 \\
\hline 20 & 3,579 & 11,359 & 18,336 & 9,067 \\
\hline 21 & 3,654 & 11,817 & 19,225 & 9,398 \\
\hline 22 & 3,727 & 12,271 & 20,113 & 9,725 \\
\hline 23 & 3,798 & 12,722 & 20,999 & 10,049 \\
\hline 24 & 3,868 & 13,168 & 21,885 & 10,368 \\
\hline 25 & 3,935 & 13,612 & 22,770 & 10,684 \\
\hline 26 & 4,001 & 14,051 & 23,653 & 10,997 \\
\hline 27 & 4,066 & 14,488 & 24,536 & 11,307 \\
\hline 28 & 4,130 & 14,921 & 25,417 & 11,613 \\
\hline 29 & 4,192 & 15,352 & 26,298 & 11,917 \\
\hline 30 & 4,253 & 15,780 & 27,177 & 12,218 \\
\hline
\end{tabular}

On the other hand, Figure 58 shows the graphic evolution of each of these functions, in order to have a clearer view of what its evolution is: 


\section{C4}

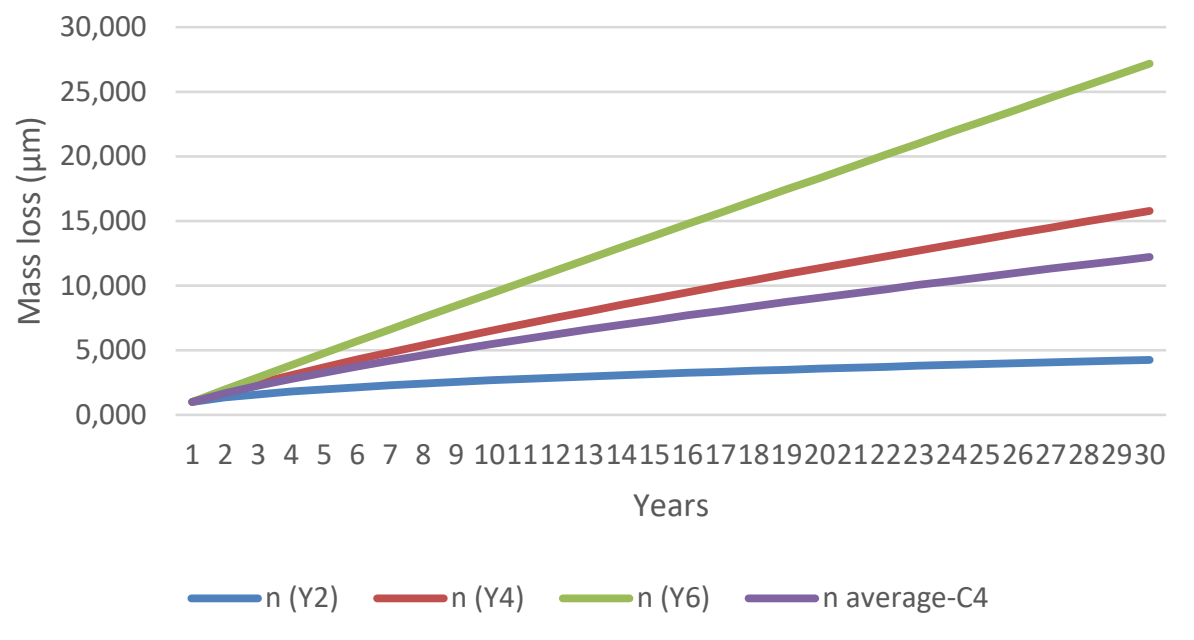

Figure 58: Yearly mass loss graphic evolution in C4 corrosivity category for each of the calculated values of $n$

Several conclusions can be drawn when analysing this corrosivity category:

- $\quad$ All $n$ values are less than 1

- $\quad n$ values vary from 0,425 , for Y2, to 0,971 , for Y6. For year 2 this value is such a low value. This is because the variation from corrosion $\mathrm{Y} 1(1,001 \mu \mathrm{m})$ to $\mathrm{Y} 2(1,34 \mu \mathrm{m})$ is very low, when compare for instance from Y2 $(1,34 \mu \mathrm{m})$ to Y4 $(3,08 \mu \mathrm{m})$. This low value of $n$ for Y2 $(0,425)$ and the big gap with Y4 $(0,811)$ and Y6 $(0,971)$, provokes an average value of $n$ relatively low $(0,736)$, buy in the end is considering the low growth of corrosion in the 2 first years of exposure. That's is the reason why the error for Y2 compared with the average value of corrosion is quite high $(23,996 \%)$.

- Error for Y6 is quite high (52,336\%). This is caused by the previously mentioned low value of $n$ for Y2, since the average value of $n(0,736)$ is highly decreased and with a high difference with the high value of $n$ in $\mathrm{Y} 6(0,971$ vs 0,736$)$.

- As a conclusion, even all the previous points that must be considered when making the calculation of the long-term corrosion, the lower error $(10,992 \%)$ from all the cases is for the $\mathrm{C} 4$ value of $n(0,811)$. After, this should be the value more precise to use.

d) C5 corrosivity category

Table 59 shows the values of mass loss for C5 corrosivity category for year 2 (it must be remembered that there are only data available for year 1 and year 2 in this corrosivity category), by solving the following function referred in Table 55, from year 1 to year 30:

Equation 26: Corrosion function for C5 corrosivity category-Year 2

$$
C(t)=3,267 * t^{1,494}
$$

(Equation 26) 
Table 59: Yearly mass loss evolution in C5 corrosivity category for the calculated value of $n$

\begin{tabular}{|c|c|}
\hline \multirow[t]{2}{*}{ Year } & $\begin{array}{c}\text { Mass loss }(\mu \mathrm{m}) \\
\text { C5 corrosivity category }\end{array}$ \\
\hline & $\mathrm{n}(\mathrm{Y} 2)$ \\
\hline 1 & 3,267 \\
\hline 2 & 9,200 \\
\hline 3 & 16,859 \\
\hline 4 & 25,910 \\
\hline 5 & 36,161 \\
\hline 6 & 47,481 \\
\hline 7 & 59,776 \\
\hline 8 & 72,972 \\
\hline 9 & 87,009 \\
\hline 10 & 101,840 \\
\hline 11 & 117,423 \\
\hline 12 & 133,722 \\
\hline 13 & 150,706 \\
\hline 14 & 168,348 \\
\hline 15 & 186,624 \\
\hline 16 & 205,512 \\
\hline 17 & 224,992 \\
\hline 18 & 245,047 \\
\hline 19 & 265,660 \\
\hline 20 & 286,815 \\
\hline 21 & 308,500 \\
\hline 22 & 330,701 \\
\hline 23 & 353,406 \\
\hline 24 & 376,604 \\
\hline 25 & 400,284 \\
\hline 26 & 424,436 \\
\hline 27 & 449,052 \\
\hline 28 & 474,123 \\
\hline 29 & 499,639 \\
\hline 30 & 525,594 \\
\hline
\end{tabular}

On the other hand, Figure 59 shows the graphic evolution of this function, in order to have a clearer view of what its evolution is: 


\section{C5}

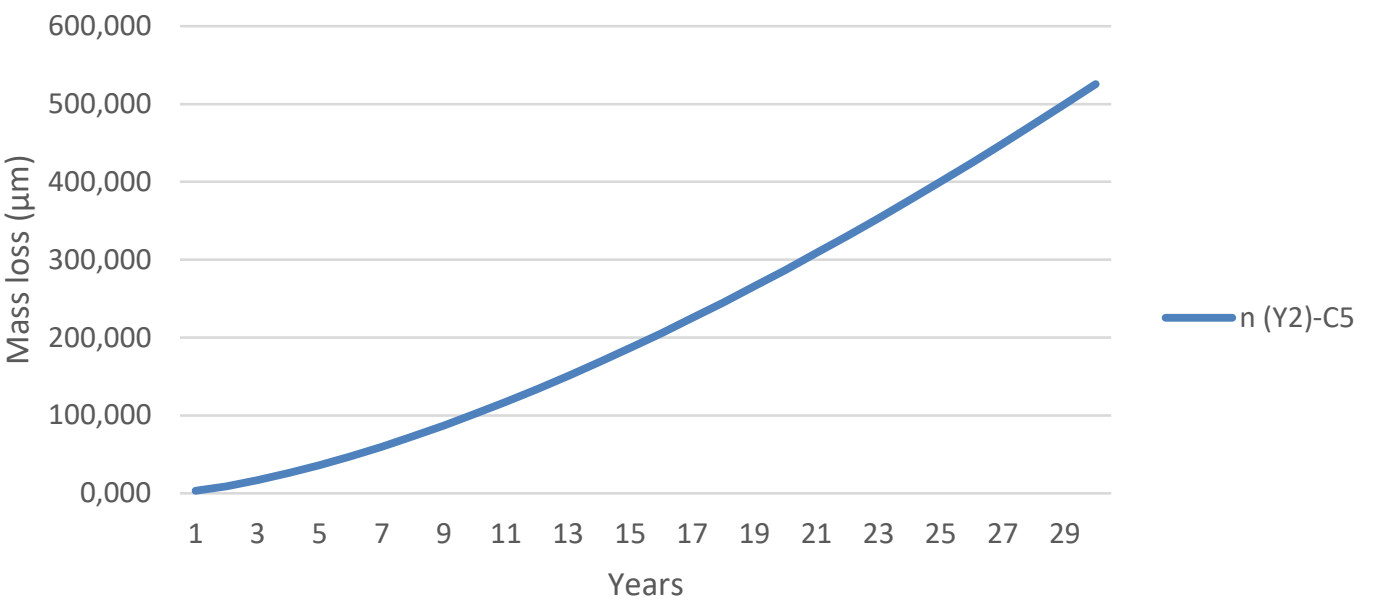

Figure 59: Yearly mass loss graphic evolution in C5 corrosivity category for the calculated value of $n$

The first remarkable point of this function is that $n$ value is abnormally superior to $1(1,494)$. That makes the exponential function has a high slope. This reflects the important leap from the average of corrosion between year $1(3,27 \mu \mathrm{m})$ and year $2(9,20 \mu \mathrm{m})$. But still, as it was said previously, the statistical values for this corrosivity category are really low (3 values for year 1 and 1 value for year 2), according to Table 40. With such low number of values, the use of Equation 26 should only be considered for having just an estimation or order of magnitude and not for precise calculations.

\section{e) CX corrosivity category}

Table 60 shows the values of mass loss for CX corrosivity category for year 2 (it must be remembered that there are only data available for year 1 and year 2 in this corrosivity category), by solving the following function referred in Table 55, from year 1 to year 30:

Equation 27: Corrosion function for CX corrosivity category-Year 2

$$
C(t)=6,225 * t^{1,040}
$$

(Equation 27) 
Table 60: Yearly mass loss evolution in CX corrosivity category for the calculated value of $n$

\begin{tabular}{|c|c|}
\hline \multirow[t]{2}{*}{ Year } & $\begin{array}{l}\text { Mass loss }(\mu \mathrm{m}) \\
\text { CX corrosivity category }\end{array}$ \\
\hline & n (Y2) \\
\hline 1 & 6,225 \\
\hline 2 & 12,800 \\
\hline 3 & 19,514 \\
\hline 4 & 26,320 \\
\hline 5 & 33,195 \\
\hline 6 & 40,125 \\
\hline 7 & 47,102 \\
\hline 8 & 54,119 \\
\hline 9 & 61,172 \\
\hline 10 & 68,255 \\
\hline 11 & 75,368 \\
\hline 12 & 82,506 \\
\hline 13 & 89,668 \\
\hline 14 & 96,852 \\
\hline 15 & 104,057 \\
\hline 16 & 111,281 \\
\hline 17 & 118,523 \\
\hline 18 & 125,783 \\
\hline 19 & 133,058 \\
\hline 20 & 140,349 \\
\hline 21 & 147,654 \\
\hline 22 & 154,973 \\
\hline 23 & 162,306 \\
\hline 24 & 169,651 \\
\hline 25 & 177,009 \\
\hline 26 & 184,378 \\
\hline 27 & 191,759 \\
\hline 28 & 199,150 \\
\hline 29 & 206,552 \\
\hline 30 & 213,965 \\
\hline
\end{tabular}

On the other hand, Figure 60 shows the graphic evolution of this function, in order to have a clearer view of what its evolution is: 


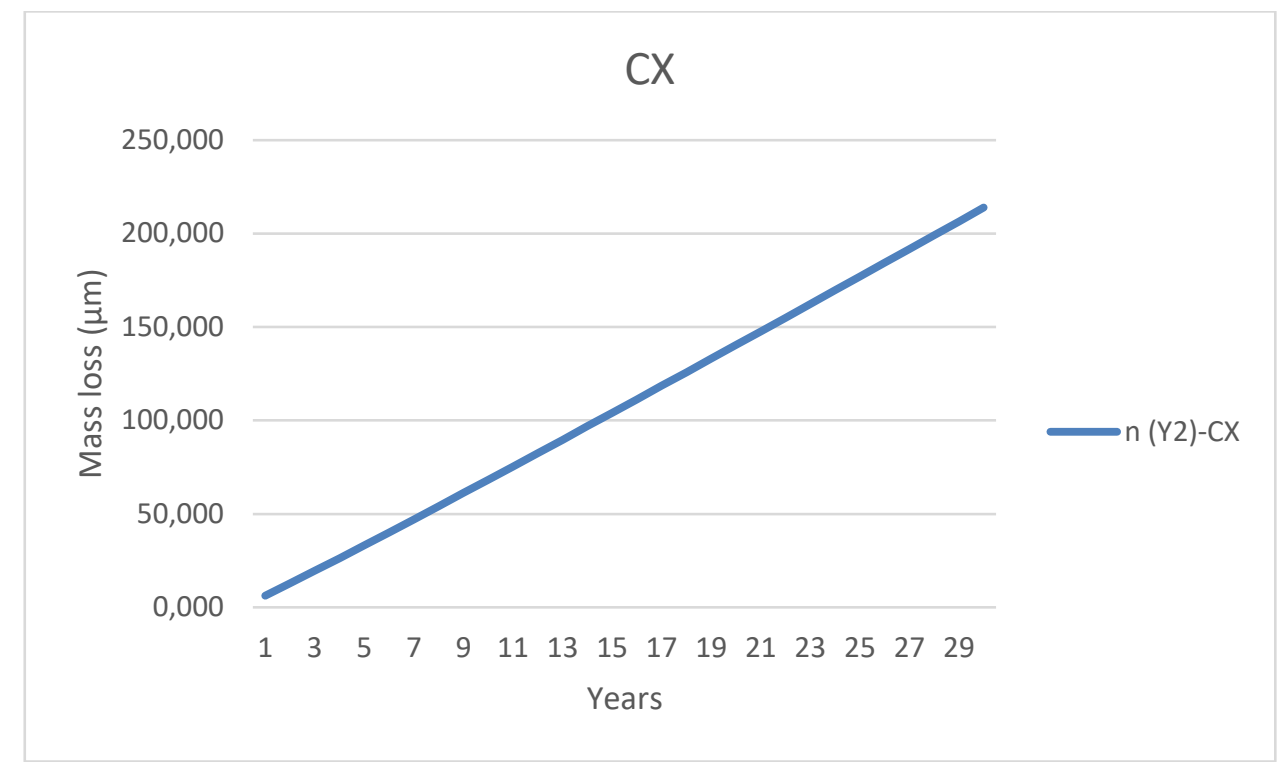

Figure 60: Yearly mass loss graphic evolution in CX corrosivity category for the calculated value of $n$

As well as for C5 corrosivity category, the first remarkable point of this function is that $n$ value is superior to 1 $(1,040)$, which returns, practically, a linear function. The exponential function has as well a high slope. This reflects the important leap from the average of corrosion between year $1(6,23 \mu \mathrm{m})$ and year $2(12,80 \mu \mathrm{m})$, which is almost double. But still, as it was said previously, the statistical values for this corrosivity category are really low (4 values for year 1 and 2 values for year 2), according to Table 40. With such low number of values, the use of Equation 27 should only be considered for having just an estimation or order of magnitude and not for precise calculations.

f) Average of corrosivity categories

Looking at Figure 61, where the corrosion functions are represented for all corrosivity categories using its average $n$ value, it can clearly be seen the important gap between C2, C3, C4 and C5, CX corrosivity categories. As it was said previously, the functions for C5 and CX shall be discarded in this research work, due to the lack of enough statistical values which returns inconsistent information.

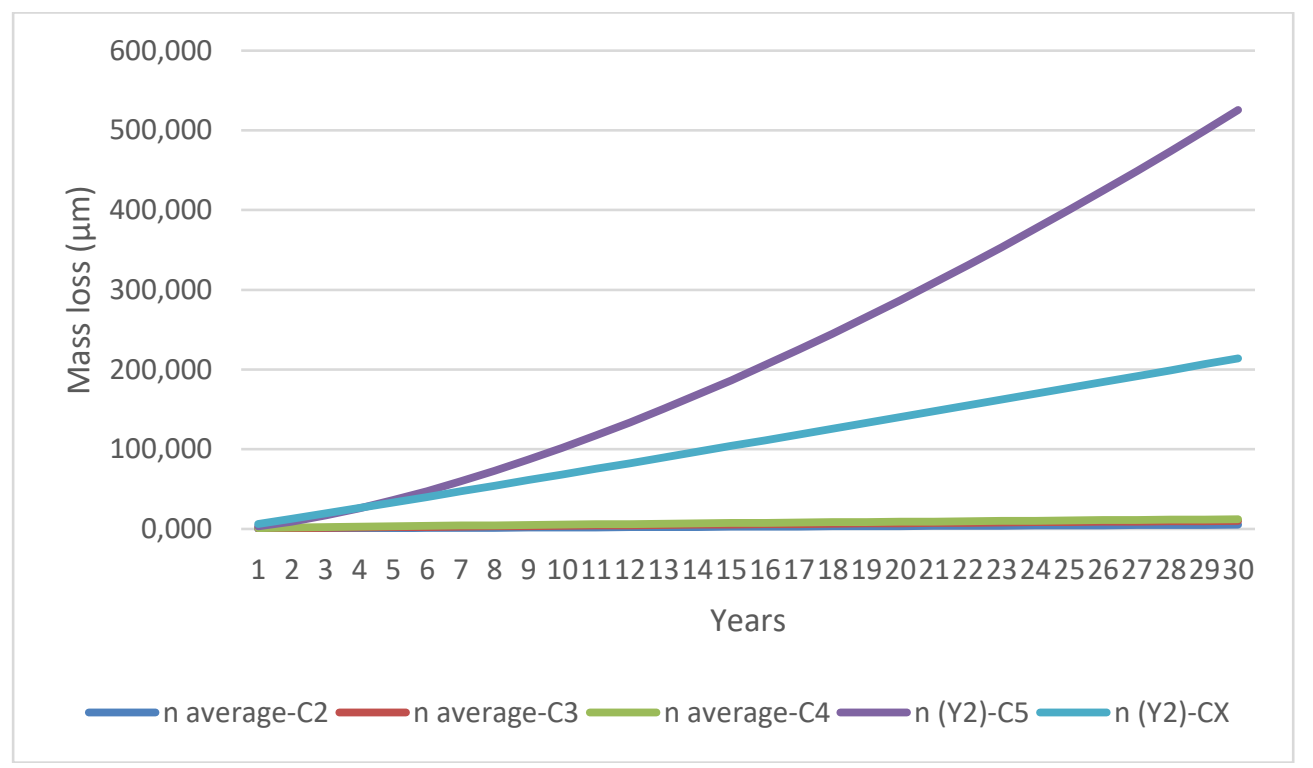

Figure 61: Yearly mass loss graphic evolution for all corrosivity categories using the average of of $n$ values 
Figure 62 shows the corrosion functions C2, C3 and C4, discarding C5 and CX corrosivity categories.

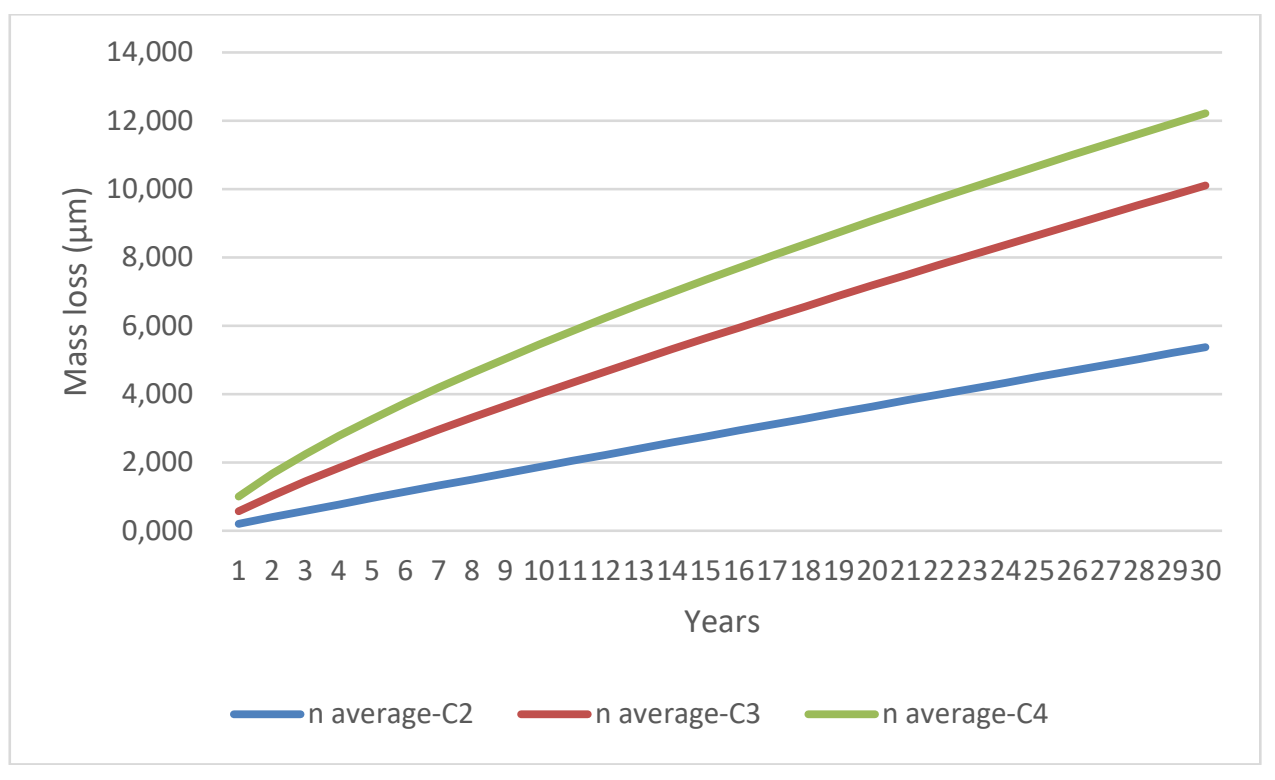

Figure 62: Yearly mass loss graphic evolution for C2, C3 and C4 corrosivity categories using the average of $n$ values

This figure should be the one to be used for long-term corrosion calculation, always considering the level of error introduced by the fact of using an average value of $n$, as described in Table 55 .

\section{CASE STUDY}

\subsection{Part I: Duration calculation from a given thickness coating}

In this first part of the case study, the way of calculating the maximum duration in years of a ZM coating from a given thickness, will be shown. It will be used the thesis outcome results for this purpose.

In addition, and with the aim of corroborate Hypothesis 2 of this thesis, it will be made the same calculation for $\mathrm{Z}$ finish, using as a way of reference the parameters and guidelines given in ISO 9223, i.e. first year corrosion values (see Table 11) and $n$ values (see Table 13).

The materials to be used for the comparison will be:

- standard coating thickness corresponding to a ZM alloy with the following designation, according to EN 10346

(CEN, 2015):

Steel EN 10346 - DX53D+ZM310-M-B-O

Where, according to the referred standard, DX53D corresponds to the type of base material, ZM310 identifies the type of coating and its mass: zinc-aluminium-magnesium alloy of $310 \mathrm{~g} / \mathrm{m}^{2}$ in the 2 faces of the total coated surface. According to Table 15, this coating mass corresponds to a typical thickness value of $24 \mu \mathrm{m}$.

- standard equivalent coating thickness corresponding to a $\mathrm{Z}$ coating, which designation, also according to EN 10346, is:

Steel EN 10346 - DX53D+Z350-M-B-O

Where, according to the referred standard DX53D corresponds to the type of base material, Z350 identifies the type of coating and its mass: zinc of $350 \mathrm{~g} / \mathrm{m}^{2}$ in the 2 faces of the total coated surface. According to Table 15 , this coating mass corresponds to a typical thickness value of $25 \mu \mathrm{m}$. Since there's an acceptable range of the standard for this thickness: [17-33] $\mu \mathrm{m}$, in order to have the same thicknesses in ZM and Z, a value of $24 \mu \mathrm{m}$ will be used.

As it was previously commented, to make the calculation of the duration of the coating of the referred material, for each of the environments characterized through its corrosivity category, according to ISO 9223, it will be used 2 different methodologies: one for the duration of the $\mathrm{Z}$ coating and the other for the duration of the referred $\mathrm{ZM}$ alloy. Both methodologies were previously detailed in Figure 25 ( $\mathrm{Z}$ finishes) and Figure 26 (ZM finishes): 
a) Methodology for $Z$ coating

The methodology chosen to calculate the duration of a zinc-based coating, is based in the standard ISO 9223, that uses also Equation 1: General long-term corrosion expression. Thus, from that equation, the parameter $t$ will be cleared, in such a way that we will find Equation 28:

Equation 28: Calculation of $t$ parameter from the general corrosion expression

$$
\mathrm{t}=10^{(\log (\mathrm{C} / \mathrm{A})) / \mathrm{n})}
$$

(Equation 28)

Once cleared $t$ parameter, next steps will be followed:

- Determination of $C$ parameter. This corresponds to the thickness of the coating chosen, i.e., $24 \mu \mathrm{m}$

- Determination of $A$ parameter, which represents the corrosion of the first year of exposure. This is given by ISO 9223 (see Table 11), which brings a range of values for this parameter for each of the corrosivity categories.

- $\quad$ Determination of $n$ parameter, for which, as it has been explained in Table 13, ISO 9224 gives 2 possible values (B1 and B2), that for the application of this methodology they will be called $\mathrm{n}_{\min }$ and $\mathrm{n}_{\max }$. Thus, the duration will be calculated for both values.

- Once the values of all the necessary parameters are obtained, the duration for each case will be calculated, applying the aforementioned Equation 28.

- As it was said before, the calculations will be made for each corrosivity category, for each of the 2 values of the range of first year corrosion and for each of the $2 n$ values. Below, it is shown an example of calculation for $C 2$ corrosivity category for $n=0,813$ :

- Parameters to be considered:

- $\mathrm{C}=24 \mu \mathrm{m}$

- $\quad A$ (minimum value $)=r_{\text {corr }} \min =0,1$

- $\mathrm{A}$ (maximum value $)=r_{\text {corr }} \max =0,7$

- $\mathrm{n}_{\min }=0,813$

- Duration (max) calculation applying Equation 28:

- $\mathrm{t}=10^{(\log (\mathrm{C} / \mathrm{A})) / \mathrm{n})}$

- $\mathrm{t}=10^{(\log (24 / 0,1) / 0,813)}=846,62$ years

○ Duration ( $\mathrm{min}$ ) calculation applying Equation 28:

- $\mathrm{t}=10^{(\log (\mathrm{C} / \mathrm{A})) / \mathrm{n})}$

- $\mathrm{t}=10^{(\log (24 / 0,7) / 0,813)}=77,31$ years

The rest of the results have been calculated in the same way and are shown in full, in Table 61, under the cell $Z$ duration according to ISO 9223. The worse cases, i.e., minimum corrosion values from all the calculated cases, are highlighted in bold letter.

b) Methodology for ZM coating

As it was explained in the introduction of this clause, the methodology used to calculate the duration of ZM alloy coating, is based in the outcome of the thesis seen in previous clauses. This methodology is also based in Equation 1 and in the same way, parameter $t$ will be cleared, so to have as well Equation 28 .

Once cleared $t$ parameter, next steps will be followed:

- $\quad$ Determination of $C$ parameter. This corresponds to the thickness of the coating chosen, i.e., $24 \mu \mathrm{m}$

- Determination of $A$ parameter, which represents the corrosion of the first year of exposure. $A$ values will be taken from Table 55, for each of the corrosivity categories.

- Determination of $n$ parameter. As it was seen in previous clauses and summarized in Table 55, it was calculated a specific $n$ value for each of the years analysed in each corrosivity category. It will be analysed 3 scenarios:

- Average $n$ value (average duration)

- Minimum $n$ value (maximum duration, according to Equation 28)

- Maximum $n$ value (minimum duration according to Equation 28) 
- $\quad$ Once the values of all the necessary parameters are obtained, the duration for each case will be calculated, applying the aforementioned Equation 28.

- $\quad$ As it was said before, the calculations will be made for each corrosivity category and for each of the $3 n$ values referred before (average, maximum and minimum). Below, as well as for $\mathrm{Z}$ finish, it is shown an example of calculation for C2 corrosivity category:

- Parameters to be considered:

- $C=24 \mu \mathrm{m}$

- $A=0,202 \mu \mathrm{m}$

- $n_{\text {average }}=0,964$

- $n_{\text {minimum }}=0,745$

- $n$ maximum $=1,099$

○ Duration (average) calculation applying Equation 28:

- $\mathrm{t}=10^{(\log (\mathrm{C} / \mathrm{A})) / \mathrm{n})}$

- $\mathrm{t}=10^{(\log (24 / 0,202) / 0,964)}=141,73$ years

○ Duration ( $\max$ ) calculation applying Equation 28:

- $\mathrm{t}=10^{(\log (\mathrm{C} / \mathrm{A})) / \mathrm{n})}$

- $\mathrm{t}=10^{(\log (24 / 0,202) / 0,745)}=607,03$ years

○ Duration ( $\min )$ calculation applying Equation 28:

- $\mathrm{t}=10^{(\log (\mathrm{C} / \mathrm{A})) / \mathrm{n})}$

- $\mathrm{t}=10^{(\log (24 / 0,202) / 1,099)}=76,98$ years

The rest of the results have been calculated in the same way and are shown in full, in Table 61, under the cell $Z M$ duration according to thesis. The worse cases, i.e., minimum corrosion values from all the calculated cases, are highlighted in bold letter.

Table 61: Case study - Part I: Calculated duration (years) for a 24 microns coating thickness for Z and ZM finishes

\begin{tabular}{|c|c|c|c|c|c|c|c|c|c|}
\hline \multirow{3}{*}{$\begin{array}{l}\text { Corrosivity } \\
\text { category } \\
\text { ISO } 9223\end{array}$} & \multicolumn{6}{|c|}{$\mathrm{Z}$ duration according to ISO 9223} & \multirow{2}{*}{\multicolumn{3}{|c|}{$\mathrm{ZM}$ duration according to thesis }} \\
\hline & \multicolumn{2}{|c|}{$\begin{array}{c}\text { First year } \\
\text { corrosion range } \\
(\mu \mathrm{m} / \mathrm{year})\end{array}$} & \multicolumn{2}{|c|}{$\begin{array}{c}\text { Duration for } \\
\mathrm{n}(\min )=0,813\end{array}$} & \multicolumn{2}{|c|}{$\begin{array}{c}\text { Duration for } \\
\mathrm{n}(\max )=0,873\end{array}$} & & & \\
\hline & $\mathrm{r}_{\text {corr }} \min$ & $\begin{array}{l}\mathrm{r}_{\text {corr }} \\
\max \end{array}$ & $\begin{array}{c}\text { Duration } \\
\text { (max) }\end{array}$ & $\begin{array}{c}\begin{array}{c}\text { Duration } \\
\text { (min) }\end{array} \\
\end{array}$ & $\begin{array}{c}\text { Duration } \\
\text { (max) }\end{array}$ & $\begin{array}{c}\text { Duration } \\
\text { (min) }\end{array}$ & $\begin{array}{c}\begin{array}{c}\text { Duration } \\
\text { (average) }^{\mathrm{a}}\end{array} \\
\end{array}$ & $\begin{array}{c}\text { Duration } \\
(\max )^{\mathrm{b}}\end{array}$ & $\begin{array}{c}\text { Duration } \\
(\min )^{c}\end{array}$ \\
\hline $\mathrm{C} 2$ & 0,1 & 0,7 & 846,62 & 77,31 & 532,69 & $\mathbf{5 7 , 3 4}$ & 141,73 & 607,03 & $\mathbf{7 6 , 9 8}$ \\
\hline $\mathrm{C} 3$ & 0,7 & 2,1 & 77,31 & 20,01 & 57,34 & 16,29 & 83,55 & 107,79 & 60,34 \\
\hline $\mathrm{C} 4$ & 2,1 & 4,2 & 20,01 & 8,53 & 16,29 & 7,36 & 75,13 & 1756,10 & 26,39 \\
\hline $\mathrm{C} 5$ & 4,2 & 8,4 & 8,53 & 3,64 & 7,36 & 3,33 & 3,80 & 3,80 & 3,80 \\
\hline $\mathrm{CX}$ & 8,4 & 25 & 3,64 & 0,951 & 3,33 & 0,954 & 3,66 & 3,66 & 3,66 \\
\hline
\end{tabular}

NOTE: Values in bold letter, represent the minimum duration (worse case) in both analysis (ISO 9223 and thesis)

${ }^{a}$ For the Thesis calculation of "Duration (average)" it has been used the average $n$ value from all calculated years.

${ }^{b}$ For the calculation of "Duration (max)" it has been used the minimum $n$ value from all the calculated years.

${ }^{c}$ For the calculation of "Duration ( $\left.\mathrm{min}\right) "$ it has been used the maximum $n$ value from all the calculated years.

\subsection{Part II: Corrosion calculation from a given exposition time}

In this part, the opposite case will be analysed, that is, the calculation of corrosion from a given duration of time. Knowing this corrosion, the project engineer will be able to choose the right material and coating thickness, so to ensure the corrosion resistance of the material for the warranty time.

The methodologies to be applied are based in the same approach that in Part I. Thus, it will split this analysis in 2 parts as well: the first to be applied for $\mathrm{Z}$ finishes ( 
Figure 27) and the second to be applied for ZM finishes (Figure 28). As it was said in Part I, this comparison aims to corroborate Hypothesis 2 of this thesis.

It will be used in this case study an example of an installation with a demanded warranty time of 20 years. The question to be solved is, what the minimum coating thickness should be chosen, to ensure this warranty time until first maintenance, or in other words, the minimum coating thickness to prevent the installation from red rust appearance before 20 years.

a) Methodology for $Z$ coating

As well, as in Part I, the methodology chosen to calculate the duration of a zinc-based coating, is based in the standard ISO 9223, that uses also Equation 1: General long-term corrosion expression.

Next steps will be followed:

- Determination of $A$ parameter, which represents the corrosion of the first year of exposure. This is given by ISO 9223 (see Table 11), which brings a range of values for this parameter for each of the corrosivity categories.

- Determination of $t$ parameter. This corresponds to the required warranty period: 20 years.

- Determination of $n$ parameter, for which, as it has been explained in Table 13, ISO 9224 gives 2 possible values (B1 and B2), that for the application of this methodology they will be called $\mathrm{n}_{\min }$ and $\mathrm{n}_{\max }$. Thus, the corrosion will be calculated for both values.

- Once the values of all the necessary parameters are obtained, the corrosion for each case will be calculated, applying the aforementioned Equation 1.

- As it was said before, the calculations will be made for each corrosivity category, for each of the 2 values of the range of first year corrosion and for each of the $2 n$ values. Below, it is shown an example of calculation for $C 2$ corrosivity category for $n=0,813$ :

- Parameters to be considered:

- $\quad A$ (minimum value $)=r_{\text {corr }} \min =0,1$

- $\mathrm{A}$ (maximum value) $=\mathrm{r}_{\text {corr }} \max =0,7$

- $\mathrm{n}_{\min }=0,813$

- Corrosion $(\max )$ calculation applying Equation 1:

- $\mathrm{C}(\mathrm{t})=A \cdot t^{n}$

- $\mathrm{C}(20)=0,7 \cdot 20^{0,813}=8 \mu \mathrm{m}$

- Corrosion (min) calculation applying Equation 1:

- $\mathrm{C}(\mathrm{t})=A \cdot t^{n}$

- $\mathrm{C}(20)=0,1 \cdot 20^{0,813}=1,14 \mu \mathrm{m}$

The rest of the results have been calculated in the same way and are shown in full, in Table 62, under the cell $Z$ corrosion according to ISO 9223. The worse cases, i.e., maximum corrosion values from all the calculated cases, are highlighted in bold letter.

b) Methodology for ZM coating

As well as in Part I of this case study, the methodology used to calculate the duration of ZM alloy coating, is based in the outcome of the thesis seen in previous clauses. This methodology is also based in Equation 1 that will be used to calculate corrosion after the given warranty time.

Next steps will be followed:

- Determination of $A$ parameter, which represents the corrosion of the first year of exposure. $A$ values will be taken from Table 55, for each of the corrosivity categories.

- Determination of $t$ parameter. This corresponds to the required warranty period: 20 years.

- Determination of $n$ parameter. As it was seen in previous clauses and summarized in Table 55, it was calculated a specific $n$ value for each of the years analysed in each corrosivity category. It will be analysed 3 scenarios:

- Average $n$ value (average corrosion)

- Minimum $n$ value (minimum corrosion, according to Equation 1)

- Maximum $n$ value (maximum corrosion according to Equation 1) 
- Once the values of all the necessary parameters are obtained, the corrosion for each case will be calculated, applying the aforementioned Equation 1.

- $\quad$ As it was said before, the calculations will be made for each corrosivity category and for each of the $3 n$ values referred before (average, maximum and minimum). Below, as well as for $\mathrm{Z}$ finish, it is shown an example of calculation for C2 corrosivity category:

- Parameters to be considered:

- $A=0,202 \mu \mathrm{m}$

- $t=20$ years

- $n_{\text {average }}=0,964$

- $n_{\text {minimum }}=0,745$

- $\quad n$ maximum $=1,099$

- Corrosion (average) calculation applying Equation 1:

- $\mathrm{C}(\mathrm{t})=A \cdot t^{n}$

- $\mathrm{C}(20)=0,202 \cdot 20^{0,964}=3,63 \mu \mathrm{m}$

- Corrosion (max) calculation applying Equation 1:

- $\mathrm{C}(\mathrm{t})=A \cdot t^{n}$

- $\mathrm{C}(20)=0,202 \cdot 20^{1,099}=5,45 \mu \mathrm{m}$

$\circ$ Corrosion (min) calculation applying Equation 1:

- $\mathrm{C}(\mathrm{t})=A \cdot t^{n}$

- $\mathrm{C}(20)=0,202 \cdot 20^{0,745}=1,89 \mu \mathrm{m}$

The rest of the results have been calculated in the same way and are shown in full, in Table 62, under the cell ZM corrosion according to thesis. The worse cases, i.e., maximum corrosion values from all the calculated cases, are highlighted in bold letter.

It is important to highlight in this table, a couple of inconsistencies between C5 and CX corrosivity categories. On one hand, for the case of ZM corrosion according to thesis, it can be noticed that the corrosion for C5 $(286,82 \mu \mathrm{m})$ is lower than for CX $(140,35 \mu \mathrm{m})$ and on the other hand, for C5 corrosivity category when it comes to Corrosion (max) comparison between Z corrosion according to ISO 9223 and ZM corrosion according to thesis, it can be noticed that $\mathrm{Z}$ corrosion $(114,84 \mu \mathrm{m})$ is lower than $\mathrm{ZM}$ corrosion $(286,82 \mu \mathrm{m})$, when for all series of data, corrosion values for $\mathrm{Z}$ are always below $\mathrm{ZM}$ values.

This is a clear sign that corrosivity categories C5 and CX results must be taken very carefully, since, as it was said in previous clauses, the number of statistical values is very low, thus, the confidence of calculations must be taken only as a reference. It is the method used in this thesis, the contribution to state of the art, subjected to improvement in the future, when having more field tests values for these specific corrosivity categories.

Table 62: Case study - Part II: Calculated corrosion (microns) for a 20 years warranty for Z and ZM finishes

\begin{tabular}{|c|c|c|c|c|c|c|c|c|c|}
\hline \multirow{3}{*}{$\begin{array}{c}\text { Corrosivity } \\
\text { category } \\
\text { ISO } 9223\end{array}$} & \multicolumn{6}{|c|}{$\mathrm{Z}$ corrosion according to ISO $9223(\mu \mathrm{m})$} & & & \\
\hline & \multicolumn{2}{|c|}{$\begin{array}{l}\text { First year corrosion } \\
\text { range }(\mu \mathrm{m} / \text { year })\end{array}$} & \multicolumn{2}{|c|}{$\begin{array}{l}\text { Corrosion }(\mu \mathrm{m}) \\
\mathrm{n}(\min )=0,813\end{array}$} & \multicolumn{2}{|c|}{$\begin{array}{l}\text { Corrosion }(\mu \mathrm{m}) \\
\mathrm{n}(\max )=0,873\end{array}$} & \multicolumn{3}{|c|}{$\begin{array}{l}\text { ZM corrosion according to thesis } \\
(\mu \mathrm{m})\end{array}$} \\
\hline & $\begin{array}{c}\mathrm{r}_{\text {corr }} \\
(\mathrm{min})\end{array}$ & $\begin{array}{l}\mathrm{r}_{\mathrm{corr}} \\
(\max )\end{array}$ & $\begin{array}{l}\text { Corrosion } \\
(\max )\end{array}$ & $\begin{array}{l}\text { Corrosion } \\
(\mathrm{min})\end{array}$ & $\begin{array}{l}\text { Corrosion } \\
(\max )\end{array}$ & $\begin{array}{l}\text { Corrosion } \\
(\min )\end{array}$ & $\begin{array}{l}\text { Corrosion } \\
\text { (average) }^{\mathrm{a}}\end{array}$ & $\begin{array}{l}\text { Corrosion } \\
(\max )^{\mathrm{b}}\end{array}$ & $\begin{array}{c}\text { Corrosion } \\
(\min )^{c}\end{array}$ \\
\hline $\mathrm{C} 2$ & 0,1 & 0,7 & 8,00 & 1,14 & $\mathbf{9 , 5 7}$ & 1,37 & 3,63 & 5,45 & 1,89 \\
\hline $\mathrm{C} 3$ & 0,7 & 2,1 & 23,99 & 8,00 & 28,71 & 9,57 & 7,18 & 8,77 & 6,25 \\
\hline $\mathrm{C} 4$ & 2,1 & 4,2 & 47,97 & 23,99 & 57,42 & 28,71 & 9,07 & 18,34 & 3,58 \\
\hline C5 & 4,2 & 8,4 & 95,94 & 47,97 & 114,84 & 57,42 & 286,82 & 286,82 & 286,82 \\
\hline $\mathrm{CX}$ & 8,4 & 25 & 285,55 & 95,94 & 341,77 & 114,84 & 140,35 & 140,35 & 140,35 \\
\hline
\end{tabular}

NOTE: Values in bold letter, represent the maximum corrosion (worse case) in both analysis (ISO 9223 and thesis)

${ }^{a}$ For the Thesis calculation of "Corrosion (av)" it has been used the average $n$ value from all calculated years.

${ }^{b}$ For the calculation of "Corrosion (max)" it has been used the maximum $n$ value from all the calculated years.

${ }^{c}$ For the calculation of "Duration (min)" it has been used the minimum $n$ value from all the calculated years. 


\subsection{Economic impact}

One of the most important applications of the outcome of this research work, for the project engineers, designers and other industrial projects professionals, is the economic factor at the time to decide what type of coating to use, and the right thickness to ensure the specifications, in terms of corrosion resistance that normally, is subjected at a type of warranty. For that reason, the knowledge about the way the corrosion is going to behave in the short, medium and long-term, is definitely a key information, in order to optimize the installation in terms of quality and cost.

This can be illustrated with an example based in the case study previously analysed, in which it will be compared at cost level, the difference of applying different type of performance coatings in terms of corrosion resistance:

For a wiring project in an electrical installation with the following specifications, it is necessary to calculate the type of coating and thickness required, to guarantee a resistance to corrosion:

- Type of environment: Classified as C4 - High (meaning a type of environment matching with the characteristics showed in Table 12: Description of typical atmospheric environments related to the estimation of corrosivity categories (Source: ISO 9223).

- $\quad$ Type of electrical cable management systems required: Standard metallic galvanized cable tray.

- $\quad$ Size required: $60 \times 200 \mathrm{~mm}$ (high x width)

- Warranty period before first maintenance: 20 years

It will be followed these steps for this analysis:

a) Thickness needed to withstand 20 years for a zinc-based coating. According to Table 62, we have these maximum values of corrosion for a $\mathrm{C} 4$ corrosivity category:

i. $\mathrm{Z}: 57,42 \mu \mathrm{m}$

ii. $\mathrm{ZM}: 18,34 \mu \mathrm{m}$

b) Search for the type of cable tray according to the referred specifications. Taken as a basis the company Pemsa $^{\circledR}$, a Spanish cable management specialist, we can find in their catalogue and price list (Pemsa, $2018,2020)$ the following information:

i. Pemsaband ${ }^{\circledR}$ : Metal cable tray RX 60x200 mm; PG finish (pre-galvanized); reference: 76122200; thickness designation: Z275 (corresponding to a typical thickness coating of $20 \mu \mathrm{m}$ according to Table 15). PVP price: $59 € / \mathrm{m}$ (the price in PG is $51,31 € / \mathrm{m}$, but it is multiplied by a factor of 1,15 which is the normal factor applied to standard $P G$ finishes for the equivalent quality in ZM alloy). This tray is the one matching with the specifications in case of using a ZM solution.

ii. Pemsaband ${ }^{\circledR}$ : Metal cable tray RX 60x200 mm; GC finish (hot-dip galvanized); reference: 76132200 ; thickness coating: $70 \mu \mathrm{m}$ according to Table 3 of ISO 1461 (CEN, 2009)). PVP price: $80,34 € / \mathrm{m}$. This tray is the one matching with the specifications in case of using a $\mathrm{Z}$ solution.

c) To sum-up, in terms of cost, to meet the project specifications we have:

i. PG solution: $59 € / \mathrm{m}$

ii. GC solution: $80,34 € / \mathrm{m}$

iii. Difference: $21,33 € / \mathrm{m}(36,16 \%)$

Thus, $36,16 \%$ is really important difference, considering that a big magnitude project can entail thousands of meters of cable tray, which at the end supposes massive savings.

Is obvious that for the same corrosion resistance request, the corrosion resistance behaviour, seriously affects not only corrosion performance but also the cost of a given project. On the other hand, is also important to have in mind the limitations in terms of thickness that ZM coatings have at the date of today with a maximum thickness of $35 \mu \mathrm{m}$ (coating designation ZM430 according to Table 15), while zinc-based coatings hot-dip galvanized can reach several hundred microns.

Once again, it is being consider the hypothesis of a logarithmic behaviour with a long-term curve like the one showed in previous clauses and this, must be carefully taken. 


\section{CONCLUSIONS, SYNTHESIS OF CONTRIBUTIONS AND FUTURE RESEARCHES}

\subsection{Conclusions}

A complete review of alloys based in $\mathrm{Zn}-\mathrm{Al}-\mathrm{Mg}$ (designated as $\mathrm{ZM}$ alloys) has been made, looking at all relevant aspects of the topic: characterization, structure and composition, corrosion behaviour, standards and designations, key raw material suppliers and market offer, key electrical cable trays manufacturers and market offer as an example of its practical application in the industrial projects, and finally, field and accelerated corrosion tests.

This review has been complemented with a methodology to estimate the long-term corrosion resistance of these alloys. This is because, unlike traditional zinc coatings, there are very few real tests for ZM alloys that can correlate the results obtained in accelerated corrosion tests, with the long-term behaviour in real locations. The equations calculated with this method have to be carefully taken, since they are based in the actual limited field tests values. In the next years, more field tests values will be available, and this research work should be complemented, having much more statistical values, so to have a better accuracy in this long-term calculation.

Another important part of the hypothesis that has been considered for this long-term corrosion calculation, is the logarithmic behaviour, as it will be later discuss in these conclusions.

In any case, the results can serve as a reference point to project engineers, researchers and other professionals, who need to determine the best choice of material based on ZM alloys and can also evaluate the advantages and disadvantages of these new alloys compared to traditional zinc-based coatings.

Going deeply into the main conclusions of this thesis, they can be summarized as follows:

- $\quad$ ZM manufacturers claims the better performance in front of Z for corrosion. There's a big amount of technical and commercial literature, on this respect, that must be carefully taken, since commercial arguments are extremely based in technical features, that according to manufacturers, are based in either accelerated or field corrosion tests. but the field tests, currently available, cover only up to 6 years duration, so the assumptions of corrosion resistance of these finishes are only based on these tests and accelerated corrosion tests.

- In the same way, it is claimed the good performance in harsh atmospheres with high humidity and high chloride load, but this performance is less obvious in acid atmospheres like $\mathrm{SO}_{2}$ emissions or with low humidity, according to some research works. This should be part of deep future researches. On the other hand, it is also important to mention that more and more, in many countries, mostly from advanced economies, the level of $\mathrm{SO}_{2}$ emissions has been drastically reduced, while $\mathrm{NO}_{\mathrm{x}}$ emissions have increased.

- A structure characterization of ZM coatings in front of $\mathrm{Z}$ has been made, so to understand the difference in terms of corrosion performance. It has been analysed the structure for the corroded and not corroded status of both coatings. Most of the authors mentioned in the bibliography, agree that the key point that justify this different behaviour comes from the so-called "corrosion products", which are mainly composed of hydrozincite, $\mathrm{Zn}_{5}(\mathrm{OH})_{6}\left(\mathrm{CO}_{3}\right)_{2}$; zinc carbonate, $\mathrm{ZnCO}_{3}$ and zinc hydroxide, $\mathrm{Zn}(\mathrm{OH})_{2}$; with additions of simonkolleite, $\mathrm{Zn}_{5}(\mathrm{OH})_{8} \mathrm{Cl}_{2} \cdot \mathrm{H}_{2} \mathrm{O}$ and a carbonate-containing magnesium species.

- The scope of the thesis has covered only flat surfaces in all coatings investigated. Future research works shall include other important parts in metallic processed pieces like welding points, bending, embosses, cutted parts, either by punching, laser, etc.

- Main international standards related to ZM alloys, have been collected. In these conclusions should be highlighted:

- ISO 9223 (ISO, 2012) standard used to classify corrosivity environments. This is key, because it is the most used environments classification, and it is needed a way to differentiate the behaviour in different type of environments. Future research works shall develop models to calculate corrosion resistance based on environmental parameters (temperature, humidity, rain...) Table 11 has been used to classify the corrosivity category in field tests, evaluating the worst case of the first-year corrosion of zinc.

- ISO 9224 (CEN, 2012) regulates the long-term corrosion resistance by applying Equation 1 and giving guiding values for first year corrosion and " $n$ ". This is key in this research work since, the hypothesis of a logarithmic behaviour for ZM finishes will be taken. 
- EN 10346 (CEN, 2015)is the standard that regulate quality designations of ZM alloys, as well as its content and its coating mass (Table 15). There are equivalent international standards like JIS G 3323 (JIS (Japanese Industrial standard), 2012) and ASTM A1046 (ASTM International, 2014).

- EN 10244-2 (CEN (European Committee for Standardization), 2009) is the equivalent standard of ZM alloys for wire.

- Differences among standards in terms of quality, coating mass content, etc. have been described in detail, providing specific information, which in the end will be key to complement with corrosion resistance calculations.

- Compilation of the main ZM alloys manufacturers (Table 19), as well as an analysis of the main differences among them in terms of aluminium and magnesium content, the total mass $\left(\mathrm{g} / \mathrm{m}^{2}\right)$

- As it will be seen afterwards, a practical application case for metallic electrical cable trays has been used, to describe how the outcome of the thesis, in terms of long-term corrosion calculation, should be used. For this reason, a classification of main cable management systems manufacturers, delivering their product in ZM finish has been done (Table 21).

- One of the most important contributions of this thesis is the collection of the main corrosion field tests arranged all over the world, in which several materials, included different type of $Z$ finishes (HDG, pregalvanized, electroplated) and ZM alloys (different qualities, compositions and manufacturers), have been tested. 10 different tests have been analysed with different corrosivity categories in different type of locations. Table 38 comprises all the results, classified by location, corrosivity category, material tested and corrosion rate $(\mu \mathrm{m} / \mathrm{year})$.

- After filtering properly all the results of the referred tests, a final table has been made synthesising the corrosion rate (median, average and standard deviation) classified by corrosivity class and year of the test. This has been done in the same way for Z (Table 41), and ZM (Table 44) alloys. Those filtered tables bring very valuable information itself, to check the different values of corrosion, measured through the yearly mass loss.

- A statistical analysis has been performed for Z (Figure 29, Figure 30, Figure 31, Figure 32, Figure 33) and ZM (Figure 34, Figure 35, Figure 36, Figure 37, Figure 38) finishes, using boxplot charts as a key guideline information for the engineer to easily know for each corrosivity class. the dispersion of the corrosion rate, its distribution by quartiles, the interquartile ranges, the median, the average, maximum and minimum values, etc. For the specific case of $\mathrm{ZM}, \mathrm{C} 3$ shows a very consistent behaviour in this boxplot charts, probably due that it is the corrosivity class having the major number of values in tests. This example here, is only to highlight how important is to have in the future, same level of statistical values for all corrosivity categories, to ensure the confidence of the results and subsequent corrosion calculation method.

- In the case of $\mathrm{Z}$ coatings, results are very consistent and with a homogeneous behaviour from $\mathrm{C} 2$ to $\mathrm{C} 4$. C5 and CX shows little consistency in their results due to the lack of enough number of statistical values coming from the field tests.

- After, an analysis of the average values comparing $\mathrm{Z}$ and $\mathrm{ZM}$ has been done. A specific chart is done for each corrosivity category (Figure 39, Figure 40, Figure 41, Figure 42, Figure 43). Results clearly show, that in all corrosivity categories, mass loss ratio of $\mathrm{Z}$ is higher than for $\mathrm{ZM}$ alloys, which corroborates in that respect, one of the hypotheses of the thesis. In addition, a specific chart was performed, merging the behaviour for all corrosivity categories into one only view (Figure 44). These were the main conclusions:

- In general terms, looking at the exponential curves, the factor, $\mathrm{Z}$ mass loss minus ZM mass loss, is uniformly increased with the increase of corrosivity categories, over time.

- The largest gap is given in C4 corrosivity category, which reaches $8,90 \mu \mathrm{m}$ in year 6 .

- The largest gap for the average result corresponds to CX: 4,98 $\mu \mathrm{m}$.

- Is quite visible in the chart the big increase of mass loss for zinc in year 6 for all corrosivity categories, especially in C3 and C4, where the gap between year 4 and year 6 is 4,31 and $4,75 \mu \mathrm{m}$, respectively.

- For ZM finishes, the slopes increase with the increase of corrosivity class and over time. They are specially pronounced for C5 and CX. 
- For corrosivity categories C5 and CX, the behaviour es quite similar between Z and ZM, actually, the slope of the lines is almost the same with a small gap in between. Thus, according to this, seems that for the harshest environments (C5, CX), the gap between both coatings tends to be more aligned than for the rest $(\mathrm{C} 2, \mathrm{C} 3, \mathrm{C} 4)$ where there's a clear difference in favour of ZM alloys.

- The investigation research continues with the analysis of the information regarding differences between $\mathrm{Z}$ and ZM finishes, calculating 2 indicators: (1) Differences (Z-ZM) and (2) ratio Z/ZM of mass losses. All these values are comprised in Table 46, Table 47, Table 48. A graphical representation is showed in Figure 45, Figure 46, Figure 47 This analysis confirms, once again, the better performance during the 6 years analysed of $\mathrm{ZM}$ alloys in front of $\mathrm{Z}$, in terms of corrosion rate. In $\mathrm{C} 3$ and $\mathrm{C} 4$, the difference reaches up to 7 and $8,9 \mu \mathrm{m}$, and the rate $\mathrm{Z} / \mathrm{ZM}$ can reach around a maximum of 3 times in $\mathrm{C} 2$ and almost 4 times in $\mathrm{C} 3$ classes. Regarding Z/ZM ratio, it is also remarkable to see how the progression by corrosivity category has a clear downward curve, with the only exception between $\mathrm{C} 5$ and $\mathrm{CX}$, but once again, this must be carefully taken since the statistical values for these corrosivity classes are very little.

- Another analysis has been driven in order to check the performance of $Z$ in front of ZM across time, motivated by Hypothesis 3, argued by galvanizers associations. This hypothesis says that the difference of corrosion resistance between $\mathrm{Z}$ and $\mathrm{ZM}$ finishes decreases in time, due to the loss of the positive effect of magnesium and aluminium over time, With the information had, and up to these 6 years of field tests, it can be said that this effect occurs with the data available for 4 years (Table 51 and Figure 48, Figure 49, Figure 50, Figure 51), but when it comes to 6-years (Table 54 and Figure 52, Figure 53, Figure 54, Figure 55), this effect is not the same, and behaves in the opposite way: in all corrosivity classes the ratio es getting higher, with the only exception of $\mathrm{C} 2$ which remains flat. As a result, this is another aspect that should be included as a part of future research works on this subject.

- An analysis of long-term corrosion resistance has been performed assuming the hypothesis that the model follows the general expression for corrosion process (Equation 1). It has been calculated a specific $n$ value for year 2, year 4 and year 6 , clearing $n$ from this equation, using the first-year corrosion value. After, the general expression corresponding to each of this $n$ values in this equation has been determined.

- The long-term analysis results are shown in Table 55, which also includes the error comparing the real values coming from real field tests, with the forecasted value for each of the 6 analysed years. Once again, the corrosivity category which shows less error is $\mathrm{C} 3$, because of the big amount of statistical data, which makes the calculation more accurate and as a result, a lower error.

- For each of these equations, it has been made a graphical representation, to check the evolution of corrosion along time. Since this hypothesis couldn't be proven because the number of years analysed were too little, the results given have to be taken carefully, and that's why it has been made an analysis with the following information for each of the corrosivity categories (Figure 56, Figure 57, Figure 58, Figure 59, Figure 60):

- Corrosion evolution using $n$ value of Year 2

- Corrosion evolution using $n$ value of Year 4

- Corrosion evolution using $n$ value of Year 6

- Corrosion evolution using $n$ value average (Year 2, Year 4 and Year 6).

Finally, it has been represented in one unique chart, the behaviour of all corrosivity categories for the average $n$ value calculated for each of them, so to have them into a common view (Figure 61, Figure 62).

- The fact of having a $n$ value superior to 1 for C5 and CX corrosivity categories, is also a prove that both categories require more data to have enough confidence and accuracy. On the contrary, for $\mathrm{C} 2, \mathrm{C} 3$ and $\mathrm{C} 4, n$ values are below 1, which matches with the general corrosion behaviour of Equation 1 (the value of $n$ should always be less than 1).

- As a result, with all this charts and mathematical models, one of the main outcomes of the thesis is to provide a tool to be able to estimate corrosion behaviour of ZM finishes, and as a result, to be able to ensure the warranty required in a specific project and its costs restrictions, looking for the right balance between coating mass $\left(\mathrm{g} / \mathrm{m}^{2}\right)$ and the corrosion performance ( $\left.\mu \mathrm{m} / \mathrm{year}\right)$.

- It has been applied the methodology described to estimate the long-term duration of the coating, through a practical case based in the selection of the proper metallic cable trays systems finish for electric cable management, to ensure the warranty period and the cost restrictions. 
- Despite the fact that the corrosion resistance according to this thesis is superior at least for the first years in ZM alloys, it is important for the designer to take into account that zinc coatings by hot dip galvanizing can reach much more thickness, and in some way, compensate the lower resistance to corrosion with a higher thickness, which is one of the most important arguments to which the zinc galvanization sector refers. The current commercialized materials in ZM alloys, only reach thicknesses up to 32 microns (430 $\mathrm{g} / \mathrm{m}^{2}$ ). In the end, it is up to the project engineer to make calculations, according to the expected life duration of the installation and the corrosion rate, to properly choose the type of coating and its thickness.

- Finally, it is very important to take into account the great environmental impact what does the fact of achieving similar resistance to corrosion in ZM finishes, with a lower percentage of zinc compared to traditional coatings. This fact has an environmental impact, not only due to the amount of zinc used, but also due to other environmental aspects, such as the reduction in energy consumption and its consequent lower emission of gases into the atmosphere (for example $\mathrm{CO}_{2}$ ), the lower generation of environmental waste as a consequence of a longer life cycle, etc. In this way, many of the arguments defended by the manufacturers of this type of coatings, which were detailed in the Background section, can be corroborated as a result of the conclusions of this thesis.

\subsection{Synthesis of contributions}

- Compilation of existing field tests in the world for ZM coatings, which at the same time include Z coatings to be able to compare both types of coatings. A rigorous classification has been made based in:

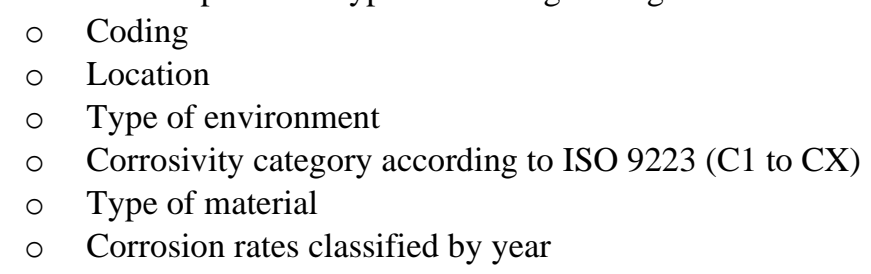

- Statistical calculation of the yearly corrosion rate ( $\mu \mathrm{m} / \mathrm{year}$ ) classified by corrosivity category, so to have for each of these categories the average, median and standard deviation. Graphical representation of the average values.

- Statistical analysis shows a clear better performance in terms of corrosion resistance of ZM alloys in front of Z. Depending on each corrosivity category, this performance can reach for instance, a maximum of 3 times in $\mathrm{C} 2$ and almost 4 times in $\mathrm{C} 3$ corrosivity categories. This demonstrates Hypothesis 1 of the thesis.

- With the graphical charts performed, there's no clear indication of a logarithmic behaviour for more years. This happens also for the $\mathrm{Z}$ charts, which is totally proven this logarithmic behaviour., thus it is needed to wait for future field tests exceeding 6 years. Thus, Hypothesis 2 could not be proven.

- Comparative analysis between $\mathrm{Z}$ and $\mathrm{ZM}$ alloys by calculating for each corrosivity category the corrosion ratios Z/ZM and Z-ZM. Graphical representation of the trend.

- For 6-years period, the ratio Z/ZM does not decrease in any of the corrosivity categories analysed. So, at least up to these 6 years, the difference of performance between $\mathrm{Z}$ and $\mathrm{ZM}$ has a positive trend being flat in the worst of the cases (C2 corrosivity category). This demonstrate, at least for this first 6-years of exposure, that Hypothesis 3 is not fulfilled.

- A mathematical model for corrosion rate calculation, depending on the corrosivity category, is provided. Also, the error in each case has been calculated. It is important to remark, that this is based in the few data had for 6-years of field tests but can be used by the designer to have an approximation of what the duration of the coating could be. Special caution must be taken with corrosivity categories C5 and CX, since the number of statistical data available is very little, and as a result, its accuracy.

- Case study of appliance in the field of electrical cable management systems for the selection of a metallic cable tray in an industrial project. It provides an example of how important the right selection of the coating is based in the referred methodology to avoid unnecessary costs, due to the prescription of an over-qualified coating or thickness coating. This corroborates Hypothesis 4.

- Positive environmental impact of ZM alloys, as a result of using less zinc to achieve the same resistance to corrosion as traditional coatings, as well as an increase in the useful life of products and more efficient manufacturing processes in terms of energy consumption and emissions. 


\subsection{Final reflection}

The rapid development and application of alloys based on zinc-aluminium-magnesium, as an alternative to traditional zinc-based coatings in recent years, has generated a significant amount of information in all areas and in a very scattered way (composition, structure, qualities, regulations, corrosion, etc.). This dispersion hinders their correct understanding and application, especially in the face of the dilemma about its usage in front of traditional coatings. The present research work solves this problem, gathering and structuring all this information, and providing engineers and final users, a complete guideline with the key features of these type of coatings and the restrictions to use them in different types of environments.

A specific part of this review work has been focussed on corrosion, where there are many types of tests but with a high dispersion. All tests found have been consolidated and it is shown the way to calculate long-term corrosion resistance based in the results of this field tests, being applied in different corrosivity categories. Included also, is the logarithmic behaviour of the corrosion function for corrosion products.

All in all, the decision about what type of coating should be chosen, will depend on several aspects, buy mostly on the conditions of the environment, and not always is obvious that these alloys can directly substitute zinc-based coatings. A previous analysis has to be done based on the given guidelines. Finally, the thickness of the commercial products offered in the market today are also relevant, since even the behaviour of ZM alloys can be better (slow corrosion speed), sometimes it could be compensated by the high thickness that can be reached in traditional zincbased coatings.

\subsection{Future researches}

For the proper continuity of the investigative work of this doctoral thesis, the following lines of research should be considered:

- $\quad$ Study in greater depth of the behaviour of ZM alloys in acidic atmospheres (accelerated tests and field tests). There are studies in which it seems that the performance of ZM alloys, decreases compared to $\mathrm{Z}$ coatings in this type of atmospheres (Galvazinc \& Cetim, 2014; Volvo, 2010a, 2010b).

- More detailed studies of types of atmospheres instead of ISO 9223 classification. This classification is very focus for zinc and another type of standard coatings, but not for ZM alloys. Further research has to be done to determine another classification and/or a model that considers the influence of environmental parameters (temperature, wetting time, rainy days, etc.), as several research programs have made for the case of zinc (Chenoll-Mora et al., 2018; Chenoll Mora, 2005)

- Study of the behaviour in real tests of non-flat surfaces: Bending, welding, drawing, mechanical cutting and laser cutting. This is one of the most complicated points where to investigate, since they entail investigation over different mechanical states of the metal, due to the tensions, deformations, differences of temperatures in the manufacturing process, etc.

- Evolution of the Z / ZM ratio, due to the contradiction found in this thesis consisting that, for 4-years a downward effect of this ratio is noted in all corrosivity classes, but in 6-years, it is an opposite effect, being up in all of them. In the long run, the objective of this future investigation is to know whether, the pass of the years can eliminate or mitigate the effect of aluminium and magnesium, in the corrosion speed, reaching similar corrosion rates than zinc.

- The data obtained with the 6-year tests are not sufficient to demonstrate that the behaviour of the corrosion curves of the ZM finishes are logarithmic according to the general function of corrosion (Equation 1). In the case of zinc, this behaviour is not either occurring in these 6-years analysis, when it is well known that zinc has a logarithmic curve corrosion-time. This fact suggests that this 6-year period of testing is still too short to corroborate Hypothesis 2.

- Detailed analysis of the resistance to corrosion, in the same way that has been done in the thesis but differentiating the precise composition of each ZM alloy. In this work all different qualities of ZM alloys have been considered as one.

- Deeper environmental quantitative impact analysis so to have a clear view about the impact of energy consumption, zinc consumption, emissions in the production process and life cycle analysis. 


\section{REFERENCES}

(VDA), V. der A. (n.d.). VDA 621-415: Testing of Corrosion Protection of Vehicle Paint by Alternating Cycles Test. VDA.

(VDA), V. der A. (2013). VDA 233-102 (E): Cyclic corrosion testing of materials and components in automotive construction. VDA.

Aiscan. (2019). Especificación de producto. Biar (Alicante): Aiscan.

Almeida, E., Rosales, M., Uruchurtu, J., Marroco, M., \& Morcillo, M. (1999). Corrosión y protección de metales en las atmósferas de Iberoamérica. Madrid (Spain): CYTED.

Arcelor Mittal. (2012). CrapalPremium - From the leader in technical steel and wire. Arcelor Mittal.

Arcelor Mittal. (2013a). Aluzinc in building. Retrieved from http://automotive.arcelormittal.com/repository/fce/Brochures/Aluzinc_brochure_EN.pdf

Arcelor Mittal. (2013b). Arcelor Mittal - Product catalogue: Crapal Trellising. Retrieved from http://www.enovitis.net/download/zica/Catalog Crapal.pdf

Arcelor Mittal. (2013c). Crapal 2 Top. Bissen (Luxembourg): Arcelor Mittal Europe Communications.

Arcelor Mittal. (2013d). Crapal Color. Bissen (Luxembourg): Arcelor Mittal Europe Communications.

Arcelor Mittal. (2013e). Magnelis. Retrieved from http://fce.arcelormittal.com/repository/fce/Brochures/Magnelis_brochure_ES.pdf

Arcelor Mittal. (2015). Interest of new generation Zn-Al3.7-Mg3.0 coatings for the Industry and Construction Market.

Arcelor Mittal. (2016). Crapal Premium. Retrieved from https://barsandrods.arcelormittal.com/wiresolutions/industrialwire/products/crapal_wire/EN

Arcelor Mittal. (2017). Magnelis: Think strategy. Retrieved from http://constructalia.arcelormittal.com/en/products/magnelis

Arcelor Mittal. (2018). Magnelis book. Arcelor Mittal Europe Communications.

Arcelor Mittal. (2020a). Magnelis for electrical equipment. Retrieved from https://industry.arcelormittal.com/industry/repository/fce/Brochures/Magneliselectricalequipment_leaflet_ EN.pdf

Arcelor Mittal. (2020b). Zagnelis® Surface - Double-sided ZnMgAl galvanized steels. Retrieved from https://automotive.arcelormittal.com/products/flat/coatings/zagnelis_surface

Association, E. G. G. (2020). EGGA. Retrieved from https://www.egga.com/ 
ASTM International. (2014). ASTM A1046 / A1046M - 14: Standard Specification for Steel Sheet, ZincAluminum-Magnesium Alloy-Coated by the Hot-Dip Process. Retrieved from https://www.astm.org/Standards/A1046.htm

Autocoat. (2013). Advanced zinc-based hot dip coatings for the automotive application. Autocoat. Brussels.

Autocoat - European Comission. (2013). Advanced zinc-based hot dip coatings for the automotive application. European Comission report. Luxembourg.

BEAMA. (2012). Best practice guide to cable ladder and cable tray systems (p. 54). p. 54. London (United Kingdom): BEAMA.

Bekaert. (n.d.). Bezinal 2000 - The cost effective alternative for heavily galvanized wires. Bekaert.

Bekaert. (2010a). Bezinal 2000 LC. Retrieved from file://C:/Users/dirdvp/Downloads/Bezinal 2000 LC_2010.pdf

Bekaert. (2010b). Bezinal 3000 - For unbeatable corrosion resistance. Bekaert.

Bekaert. (2014). Bezinal® XC - coated wire for high-end, critical springs. Retrieved from file://C:/Users/dirdvp/Downloads/Bezinal XC.pdf

Bekaert. (2017). Bezinal 3000 - Coated wire for cables and ropes. Retrieved from file:///C:/Users/dirdvp/Downloads/Bekaert-Bezinal 3000-Brochure-EN.pdf

Bekaert. (2018). Coating solutions for active corrosion resistance. Retrieved from file:///C:/Users/dirdvp/Downloads/Bekaert-active-corrosion-resistance.pdf

Benarie, M., \& Lipfert, F. L. (1986). A general corrosion function in terms of atmospheric pollutant concentrations and rain pH. Atmospheric Environment (1967), 20(10), 1947-1958. https://doi.org/10.1016/0004-6981(86)90336-7

Bertol, A. (2014). Got Rust? Get ZAM. CoilWorld, May-June 2. Retrieved from https://www.wheelingnipponsteel.com/images/pdf/got-rust-get-zam-article.pdf

BIEC. (2016). Galvalume. Retrieved June 20, 2008, from http://www.galvalume.com/

Bluescope Steel. (2008). Improved Zincalume steel Corrosion Technical Bulletin. Retrieved from http://www.bluescope.co.th/wp-content/uploads/2014/11/product_brochure_improved_zincalume.pdf

Bluescope Steel. (2013a). Next generation ZINCALUME® steel enabling the next generation of sustainable building. Retrieved from file:///C:/Users/dirdvp/Downloads/NGZAM125-Sustainability_Fact_Sheet.pdf

Bluescope Steel. (2013b). Next generation ZINCALUME® steel with Activate ${ }^{T M}$ technology. Retrieved from file://C:/Users/dirdvp/Downloads/NGZAM125-Product_Release_Guide.pdf

Bluescope Steel. (2018). Superdyna - High tensile and highly corrosion-resistant. Retrieved from https://www.nsbluescope.com/asean/wp-content/uploads/sites/2/2019/05/SuperDyma®-ProductBrochure.pdf 
Bluescope Steel. (2020). Zincalum - Next generation ZINCALUME® steel is now available with the patented Activate ${ }^{\circledR}$ technology. Retrieved from http://www.steel.com.au/products/coated-steel/zincalume-steel\#

Bozec, N. Le, Thierry, D., Persson, D., \& Stoulil, J. (2018). Atmospheric Corrosion of Zinc-Aluminum Alloyed Coated Steel in Depleted Carbon Dioxide Environments. Journal of the Electrochemical Society, 165(7), C343-C353.

Cablofil (Legrand). (2016). Technical guide. Retrieved from http://www.ecatalogue.cablofil.com/eu/XML/Page_GUIDE_TECHNIQUE/guides/technical_guide_en.pdf

CEN. (2009). EN ISO 1461 - Hot Dip Galvanized coatings on fabricated iron and steel articles - Specifications and tests methods (ISO 1461: 2009). Brussels (Belgium): European Committee for Standardization.

CEN. (2012). EN ISO 9224 - Corrosion of metals and alloys -- Corrosivity of atmospheres -- Guiding values for the corrosivity categories (ISO 9224: 2012). Retrieved from http://www.iso.org/iso/home/store/catalogue_tc/catalogue_detail.htm?csnumber=53500

CEN. (2014). EN 10088-1. Retrieved from https://standards.cen.eu/dyn/www/f?p=204:110:0::::FSP_PROJECT,FSP_ORG_ID:36733,734440\&cs=1C ECBA04C98BC8483C3C7D77DB9B2E1EF

CEN. (2015). EN 10346: Continuously hot-dip coated steel flat products for cold forming - Technical delivery conditions. Brussels (Belgium): European Committee for Standardization (CEN).

CEN. (2018). EN ISO 2081 - Metallic and other inorganic coatings - Electroplated coatings of zinc with supplementary treatments on iron or steel (ISO 2081:2018). Retrieved from https://standards.cen.eu/dyn/www/f?p=204:110:0::::FSP_PROJECT,FSP_ORG_ID:41843,6243\&cs=1739 AAED98FE347EDFECE48F88DFAD7F6

CEN (European Commitee for Standardization). (2006). EN 10143: Continuously hot-dip coated steel sheet and strip - Tolerances on dimensions and shape (2006). Retrieved from https://standards.cen.eu/dyn/www/f?p=204:110:0::::FSP_PROJECT,FSP_ORG_ID:23469,734450\&cs=12 53915B3460BCF2CA2236527E821750A

CEN (European Committee for Standardization). (1998). EN ISO 12944-1: Paints and varnishes - Corrosion protection of steel structures by protective paint systems - Part 1: General introduction (ISO 12944-1: 1998). Brussels (Belgium): European Committee for Standardization.

CEN (European Committee for Standardization). (2009). EN 10244-2: Steel wire and wire products. Nofferrous metallic coatings on steel wire. Part 2: Zinc or zinc alloys coatings. European Committee for Standardization.

CEN (European Committee for Standardization). (2012). EN ISO 9226 - Corrosion of metals and alloys -Corrosivity of atmospheres -- Determination of corrosion rate of standard specimens for the evaluation of corrosivity (ISO 9226: 2012). Retrieved from http://www.iso.org/iso/home/store/catalogue_tc/catalogue_detail.htm?csnumber=53502

CEN (European Committee for Standardization). (2017). EN ISO 12944-2: Paints and varnishes - Corrosion protection of steel structures by protective paint systems - Part 2: Classification of environments (ISO 12944-2:2017). Retrieved from https://standards.cen.eu/dyn/www/f?p=204:110:0::::FSP_PROJECT,FSP_ORG_ID:40713,6121\&cs=15C3 
Chenoll-Mora, E., Cloquell-Ballester, V., \& Santamarina-Siurana, C. (2018). Optimum selection of zinc-coated cable trunking systems for electrical installations based on atmospheric corrosion prediction Selección óptima basada en la predicción de corrosión atmosférica de sistemas The quantification of atmospheric corrosion : Novasinergia, 1(2), 5-32.

Chenoll Mora, E. (2005). Research Investigation Study - Advanced Estudies Diploma - Doctorate program. Valencia (Spain): Polytechnic University of Valencia.

Chico, B., De La Fuente, D., Vega, J. M., \& Morcillo, M. (2010). Mapas de España de corrosividad del zinc en atmósferas rurales. Revista de Metalurgia (CSIC), 46(6), 485-492. https://doi.org/10.3989/revmetalmadrid.1035

Costa, J. M., Mercer, A. D., Institute of Materials of London, European Federation of corrosion, \& Sociedad Española de Química Industrial. (1993). Progress in the understanding and prevention of corrosion. Retrieved from https://inis.iaea.org/search/search.aspx?orig_q=RN:25008679

de Rincón, O., Rincón, a., Sánchez, M., Romero, N., Salas, O., Delgado, R., ... Panosian, Z. (2009). Evaluating $\mathrm{Zn}, \mathrm{Al}$ and $\mathrm{Al}-\mathrm{Zn}$ coatings on carbon steel in a special atmosphere. Construction and Building Materials, 23(3), 1465-1471. https://doi.org/10.1016/j.conbuildmat.2008.07.002

Dean, S., \& Reiser, D. (2002). Analysis of Long-Term Atmospheric Corrosion Results from ISO CORRAG Program. In Outdoor Atmospheric Corrosion (pp. 3-3-16). https://doi.org/10.1520/STP10879S

Dutta, M., Halder, A. K., \& Singh, S. B. (2010). Morphology and properties of hot dip Zn-Mg and Zn-Mg-Al alloy coatings on steel sheet. Surface and Coatings Technology, 205(7), 2578-2584. https://doi.org/10.1016/j.surfcoat.2010.10.006

Ernesto Chenoll-Mora, \& Vicente Agustín Cloquell-Ballester. (2019). Review and long-term corrosion analysis of coatings based onZinc-Aluminium-Magnesiumalloys, as an alternative to traditional zinc-based coatings for cable trunking systemsinelectrical installations [Article]. NOVASINERGIA, 2(1), 50-79.

Feliu Batlle, S., Morcillo, M., \& Feliu, S. (1993a). The prediction of atmospheric corrosion from meteorological and pollution parameters-I. Annual corrosion. Corrosion Science, 34(3), 403-414. https://doi.org/10.1016/0010-938X(93)90112-T

Feliu Batlle, S., Morcillo, M., \& Feliu, S. (1993b). The prediction of atmospheric corrosion from meteorological and pollution parameters-II. Long-term forecasts. Corrosion Science, 34(3), 415-422. https://doi.org/10.1016/0010-938X(93)90113-U

Feliu, S., \& Morcillo, M. (1980). Estudio corrosión en atmósferas rurales en España. Revista Iberoamericana de Corrosión y Protección, XI(2), 7.

Galfan Technology Center Inc. (n.d.). Galfan. Retrieved from http://www.galfan.com/

Galol S.A. (n.d.-a). Láminas de cinc - DeltaTone 9000. Retrieved from http://www.galol.com/images/recubrimientos/CATALOGO 2012/DELTA TONE .pdf

Galol S.A. (n.d.-b). Láminas de cinc-Geomet 321, 500. Retrieved from 
http://www.galol.com/images/recubrimientos/geomet.pdf

Galvanización, A. T. E. de. (2020). ATEG. Retrieved from https://www.ateg.es/

Galvazinc, \& Cetim. (2014). Corrosion performance comparisons with competing technologies. Venice (Italy).

Gedisa. (2008). Manual de canalizaciones por sistemas de bandejas portacables. Retrieved from http://www.gedisa.com.ve/recientes_aun/catalogos/electricos/libreria_geditrays/libreria/20 CAP 2 GEDITRAYS 2007.pdf

Gewiss. (2016). No Title. Steel Wire- For a Rapid, Robust Solution. Retrieved from https://www.gewiss.com/content/dam/gewiss/press/building/bfr/000209.pdf

González Fernández, J. A. (CSIC). (1984). Teoría y práctica de la lucha contra la corrosión (1984th ed.). Madrid (Spain): Consejo Superior de Investigaciones científicas (CSIC).

Group, N. metal coatings. (n.d.). Dacromet: Una solución anticorrosión demostrada. Retrieved from http://www.nofmetalcoatings.com/_upload/ressources/interface/eur_docs/30062015_infoprd-dacrometes.pdf

Group, V. (2009). Volvo standard STD 423: Accelerated corrosion test. Stockholm: Volvo Group.

Haagenrud, S. E., Henriksen, J. F., \& Gram, F. (1985). Dose-response functions and corrosion mapping for a small geographical area. https://doi.org/17049900

Hernández, L. ., Miranda, J. M., \& Domínguez, O. (2002). Efecto protector de las capas de productos de corrosión de exposición atmosférica. Revista de Metalurgia (CSIC). Retrieved from http://revistademetalurgia.revistas.csic.es/index.php/revistademetalurgia/article/view/391/397

Hosking, N. C., Ström, M. A., Shipway, P. H., \& Rudd, C. D. (2007). Corrosion resistance of zinc-magnesium coated steel. Corrosion Science, 49(9), 3669-3695. https://doi.org/10.1016/j.corsci.2007.03.032

Hyperphisics. (2020). Retrieved from http://hyperphysics.phy-astr.gsu.edu/hbase/Tables/electpot.html

IEC. (2006). IEC 61537: Cable management - Cable tray systems and cable ladder systems (Ed. 2 - 2006). Geneva (Switzerland): International Electrotechnical Commission.

IEC. (2016). IEC 61537: Cable Management - Cable tray systems and cable ladder systems (IEC_SC23A_MT12 - CLC_TC213_WG5 - CD(2)). Geneva (Switzerland): International Electrotechnical Commission (Committee Draft, pending of publication).

IPU (Ingenieursozietät Peil Ummenhofer). (2013). Assesment of the corrosion resistance of the metallic coating Magnelis made of a zinc-magnesium-aluminum alloy. Karlsruhe (Germany).

ISO. (2012). ISO 9223 - Corrosion of metals and alloys -- Corrosivity of atmospheres -- Classification, determination and estimation. Retrieved from http://www.iso.org/iso/home/store/catalogue_tc/catalogue_detail.htm?csnumber=53499

ISO. (2020). ISO 8044: Corrosion of metals and alloys-Vocabulary. Retrieved from 
https://www.iso.org/standard/71134.html

ISO (International Organization for Standardization). (1999). ISO 10289 - Methods for corrosion testing of metallic and other inorganic coatings on metallic substrates - Rating of test specimens and manufactured articles subjected to corrosion tests. Geneva (Switzerland): International Organization for Standardization.

ISO (International Organization for Standardization). (2012a). ISO 9225 - Corrosion of metals and alloys Corrosivity of atmospheres - Measurement of environmental parameters affecting corrosivity of atmospheres. Geneva (Switzerland): International Organization for Standardization.

ISO (International Organization for Standardization). (2012b). ISO 9227: Corrosion tests in artificial atmospheres - Salt spray tests. Geneva (Switzerland): International Organization for Standardization.

ISO (International Organization for Standardization). (2015). ISO 21207 - Corrosion tests in artificial atmospheres - Accelerated corrosion tests involving alternate exposure to gases, neutral salt-spray and drying. Reference Number ISO. Retrieved from https:/www.iso.org/obp/ui/\#iso:std:iso:21207:ed-2:v1:en

Jing, C., Dong, B., Raza, A., Zhang, T., \& Zhang, Y. (2021). Corrosion inhibition of layered double hydroxides for metal-based systems. Nano Materials Science, 3(2021), 47-67. Retrieved from https://reader.elsevier.com/reader/sd/pii/S2589965120300635?token=0E38B5FB9CD18BB5548CA5BA20 2CF74691BD471BB02E14C08A576AE01D09CD46BCEC50B624495E307C8FD226E4FE3EED\&origin Region=eu-west-1\&originCreation $=20210501192800$

JIS (Japanese Industrial standard). (2012). JIS G 3323: Hot-dip zinc-aluminium-magnesium alloy-coated steel sheet and strip (2012). Japanese Industrial.

Keppert, T. A., Luckeneder, G., Stellnberger, K.-H., Mori, G., \& Antrekowitsch, H. (2014). Investigation of the Corrosion Behavior of Zn-Al-Mg Hot-Dip Galvanized Steel in Alternating Climate Tests. Corrosion, 70(12), 1238-1248. https://doi.org/0009612547; 10.5006/1158

Knotkova, D., Boschek, P., \& Kreislova, K. (1995). Results of ISOCORRAG Program: Processing of One-year Data in Respect to Corrosivity Classification, STP1239. In Atmospheric Corrosion (p. 38). https://doi.org/10.1520/STP14912S

Knotkova, D., Dean, S., \& Kreislova, K. (2010). ISOCORRAG, International Atmospheric Exposure Program: summary of results (2010th ed.). Retrieved from http://www.svuom.cz/index.php?zobraz=isocorrag\&lang=en

LeBozec, N., Thierry, D., Peltola, A., Luxem, L., Luckeneder, G., Marchiaro, G., \& Rohwerder, M. (2012). Corrosion performance of $\mathrm{Zn}-\mathrm{Mg}$-Al coated steel in accelerated corrosion tests used in the automotive industry. Istanbul (Turkey).

LeBozec, N., Thierry, D., Peltola, A., Luxem, L., Luckeneder, G., Marchiaro, G., \& Rohwerder, M. (2013). Corrosion performance of $\mathrm{Zn}-\mathrm{Mg}-\mathrm{Al}$ coated steel in accelerated corrosion tests used in the automotive industry and field exposures. Materials and Corrosion, 64(11), 969-978. https://doi.org/10.1002/maco.201206959

LeBozec, N., Thierry, D., Persson, D., Riener, C. K., \& Luckeneder, G. (2019). Influence of microstructure of zinc-aluminium-magnesium alloy coated steel on the corrosion behavior in outdoor marine atmosphere. Surface and Coatings Technology, 374, 897-909. 
Legrand. (2016). Corrosion-Resistance | Legrand. Retrieved May 18, 2017, from http://www.legrand.us/cablofil/tech_resources/corrosion-resistance/

Legrand. (2019a). Chemin de câble Zinc Aluminium. Retrieved from www.legrandcablemanagement.fr

Legrand. (2019b). Chemin de cables et accessoires. Montbard (France): Legrand Cable Management.

Legrand. (2019c). Gagnez en résistance. https://doi.org/LCM219004

Maccaferri. (2015). Galmac 4R - Revestimiento metálico de larga vida útil. Maccaferri.

Magni. (2020). Magni- Performance covered. Retrieved from https://magnicoatings.com/

Mavil (Gewiss group). (2015). Cable trays High Protection For harsh conditions Domotics Energy Lighting (pp. 115-118). pp. 115-118. Retrieved from http://www.mavil.com

Mazzoleni. (2016). Galvalid. Retrieved from http://www.mazzoleni.it/galvalid/gal,es.htm

Microcapas. (2020). Delta-Tone, sistema inorgánico de microcapa. Retrieved from http://www.microcapas.com

Morcillo, M. (1998). Predicción a corto y largo plazo de la corrosión atmosférica de metales. Revista de Metalurgia (CSIC).

Morcillo, M., \& Feliu, S. (1987). Estudio corrosión en atmósferas rurales en España. Revista Iberoamericana de Corrosión y Protección, XVIII(2-6), 311.

Morcillo, M., \& Feliu, S. (1993). Mapas de España de corrosividad atmosférica (1993rd ed.; M. Morcillo Linares \& S. Feliu Matas, Eds.). Madrid (Spain): CYTED (Programa Iberoamericano de ciencia y tecnología para el desarrollo.

Nisshin. (2015). ZAM - Corrosion protection of the 21st century. Retrieved from http://www.nisshinsteel.co.jp/en/products/surface.html

Nisshin Steel. (n.d.). ZAM - Nisshin Steel Quality Products. Retrieved from https://www.wheelingnipponsteel.com/images/pdf/zam-tech-brochure.pdf

Nisshin Wheeling. (n.d.). Wheeling Nisshin Inc. Retrieved from http://www.wheelingnisshin.com/images/pdf/wheeling-nisshin-brochure.pdf

NOF Metal Coatings Group. (n.d.). NOF METAL COATINGS GROUP. Retrieved from http://www.nofmetalcoatings.com/

NOF Metal Coatings Group. (2012). GEOMET 321. Nof metals coating group.

Nordic Galvanizers. (n.d.). Corrosion performance - Real performance evaluations in infraestructure applications. Stockholm.

Obo Betterman. (2012). Double Dip: The new galvanising process with outstanding long-term protection. Obo 
Betterman.

Ocampo, M. (1986). Inversión térmica y contaminación. Información Científica y Tecnológica, 8(115), 19-21.

OneSteel. (2016). Zalcote - Superior corrosion performance. OneSteel.

Panchenko, Y. M., Marshakov, A. I., Igonin, T. N., Kovtanyuk, V. V., \& Nikolaeva, L. A. (2014). Long-term forecast of corrosion mass losses of technically important metals in various world regions using a power function. Corrosion Science, 88, 306-316. https://doi.org/10.1016/j.corsci.2014.07.049

Panossian, Z., Mariaca, L., Morcillo, M., Flores, S., Rocha, J., Peña, J. J., ... Simancas, J. (2005). Steel cathodic protection afforded by zinc, aluminium and zinc/aluminium alloy coatings in the atmosphere. Surface and Coatings Technology, 190(2-3), 244-248. https://doi.org/10.1016/j.surfcoat.2004.04.023

Pemsa. (2018). Pemsa Price List \#156. Madrid (Spain): Pemsa.

Pemsa. (2020). Pemsa - General catalogue \#504. Madrid (Spain): Pemsa.

Persson, D., Thierry, D., \& Karlsson, O. (2017). Corrosion and corrosion products of hot dipped galvanized steel during long term atmospheric exposure at different sites world-wide. Corrosion Science, 126, 152-165. https://doi.org/10.1016/j.corsci.2017.06.025

Posco. (n.d.). PosMAC- Posco Magnesium Aluminium alloy coating product. Retrieved from https://www.posco.co.kr/homepage/docs/eng5/dn/product/info/posmac.pdf

Posco. (2018). PosMac 3.0 - Posco Magnesium Aluminium alloy coating product. Retrieved from file://C:/Users/dirdvp/Downloads/PosMAC_ENG.pdf

Pourbaix, M. (1982a). Atmospheric corrosion. In W. H. Ailor \& J. W. and Sons (Eds.), Atmospheric corrosion. New York (USA).

Pourbaix, M. (1982b). The linear bilogarithmic law for atmospheric corrosion (W. H. Ailor, Ed.). New York (USA): J. Wiley \& sons, New York.

Prosek, T., Nazarov, A., Bexell, U., Thierry, D., \& Serak, J. (2008). Corrosion mechanism of model zincmagnesium alloys in atmospheric conditions. Corrosion Science, 50(8), 2216-2231. https://doi.org/10.1016/j.corsci.2008.06.008

Prosek, Tomas, Persson, D., Stoulil, J., \& Thierry, D. (2014a). Composition of corrosion products formed on $\mathrm{Zn}-\mathrm{Mg}, \mathrm{Zn}-\mathrm{Al}$ and $\mathrm{Zn}-\mathrm{Al}-\mathrm{Mg}$ coatings in model atmospheric conditions. Corrosion Science, 86, 231238. https://doi.org/10.1016/j.corsci.2014.05.016

Prosek, Tomas, Persson, D., Stoulil, J., \& Thierry, D. (2014b). Composition of corrosion products formed on $\mathrm{Zn}-\mathrm{Mg}, \mathrm{Zn}-\mathrm{Al}$ and $\mathrm{Zn}-\mathrm{Al}-\mathrm{Mg}$ coatings in model atmospheric conditions. Corrosion Science, 86, 231238. https://doi.org/10.1016/j.corsci.2014.05.016

R\&D, A. M. G. (2015). Interest of new generation Zn-Al3.7-Mg3.0 coatings for the Industry and Construction Market. 
Renault. (2007). Essai de corrosion par changement automatique des phases BS humidite et sechage (ECC1).

Paris: Normalisation Renault automobiles.

Rich Clausius \& Arcelor Mittal. (n.d.). Zagnelis - Zinc Aluminum Magnesium coating for automotive. Retrieved from http://www.autosteel.org/ /media/Files/Autosteel/Great Designs in Steel/GDIS 2015/Track 2 Clausius.pdf

Rus, V. (2019). Factors in reliable evaluation and prediction of the corrosion performance of zinc and zinc alloy coatings.

Salgueiro Azevedo, M., Allély, C., Ogle, K., \& Volovitch, P. (2015a). Corrosion mechanisms of Zn(Mg, Al) coated steel in accelerated tests and natural exposure: 1 . The role of electrolyte composition in the nature of corrosion products and relative corrosion rate. Corrosion Science, 90, 472-481.

https://doi.org/10.1016/j.corsci.2014.05.014

Salgueiro Azevedo, M., Allély, C., Ogle, K., \& Volovitch, P. (2015b). Corrosion mechanisms of Zn(Mg,Al) coated steel: 2 . The effect of $\mathrm{Mg}$ and $\mathrm{Al}$ alloying on the formation and properties of corrosion products in different electrolytes. Corrosion Science, 90, 482-490. https://doi.org/10.1016/j.corsci.2014.07.042

Salzgitter Flachstahl. (2014). Stroncoat - The new generation of Zinc-Magnesium coatings. Retrieved from https://www.salzgitter-

flachstahl.de/fileadmin/mediadb/szfg/informationsmaterial/produktinformationen/stronsal_beschichtete_pr odukte/eng/dx52d_zm.pdf

Salzgitter Flachstahl. (2016). StronSal - Innovative coating that sets the standards. Salzgitter (Germany): Salzgitter Flachstahl.

Schneider Electric. (2011). Performa Zn+ - Your best friend in corrosive environments. High performance mesh trays. Schneider Electric.

Schneider Electric. (2012). Metalnorma Zinc+, Performa Zinc+ - Bandejas portacables para ambientes corrosivos. Schneider Electric.

Schouller-Guinnet, P., Allély, C., \& Volovitch, P. (2011). ZnAlMg: an innovative metallic coating that offers protection in the harshest environments. Genova (Italy).

Schuerz, S., Fleischanderl, M., Luckeneder, G. H., Preis, K., Haunschmied, T., Mori, G., \& Kneissl, A. C. (2009a). Corrosion behaviour of $\mathrm{Zn}-\mathrm{Al}-\mathrm{Mg}$ coated steel sheet in sodium chloride-containing environment. Corrosion Science, 51(10), 2355-2363. https://doi.org/10.1016/j.corsci.2009.06.019

Schuerz, S., Fleischanderl, M., Luckeneder, G. H., Preis, K., Haunschmied, T., Mori, G., \& Kneissl, A. C. (2009b). Corrosion behaviour of $\mathrm{Zn}-\mathrm{Al}-\mathrm{Mg}$ coated steel sheet in sodium chloride-containing environment. Corrosion Science, 51(10), 2355-2363. https://doi.org/10.1016/j.corsci.2009.06.019

Schürz, S., Luckeneder, G. H., Fleischanderl, M., Mack, P., Gsaller, H., Kneissl, A. C., \& Mori, G. (2010). Chemistry of corrosion products on $\mathrm{Zn}-\mathrm{Al}-\mathrm{Mg}$ alloy coated steel. Corrosion Science, 52(10), 3271-3279. https://doi.org/10.1016/j.corsci.2010.05.044

Shibayama, H., \& Takedomi, Y. (2015). Comparative performance of galvanizing with continuously applied ZnAl-Mg coatings. Results of exposure tests in Japan. 24th International Galvanizing Conference Intergalva. Liverpool. 
SSAB. (2016). Precision steel tube handbook. https://doi.org/978-952-93-7674-2

SSAB. (2020a). Aluzinc SSAB. Retrieved from http://aluzinc.co.uk/index.php/en/

SSAB. (2020b). SSAB - Aluzinc, The facts and figures. Brierley Hill (Switzerland): SSAB Swedish Steel Ltd.

SSAB. (2020c). SSAB - Aluzinc - Data Sheets. Retrieved from http://aluzinc.co.uk/index.php/en/aluzincinfo/coatings

SSAB. (2020d). SSAB Aluzinc. Retrieved from http://aluzinc.co.uk/images/downloads/SSAB-and-Aluzinc.pdf

Stahl. (2013). Zinc-Magnesium coated steel sheets Zinc-Magesium-Aluminium coatings for automotive industry. Retrieved from http://www.stahl-online.de/wp-content/uploads/2013/10/D566-

E_Zinc_Magnesium_Coated_Steel_Sheets.pdf

Stern, A. C. (1986). Air pollution. Volume II: The effects of air pollution (A. S. CO, Ed.). Norh Caroline (United States).

Stockholm-Environment and health administration, C. of. (2006). The Stockholm trial: Effects on air quality and health. Stockholm.

Stramit. (2012). ZAM - Zinc Aluminium Magnesium - Coated Steel products for corrosive environments.

Retrieved from http://www.stramit.com.au/sites/default/files/download-file/zam_brochure_8_page.pdf

Swerea Kimab. (2014). Alternative materials for Cable Tray systems. Kista - Sweden.

Tata Corus. (2009). Tata Steel - Annual report 2007/2008.

Tata Corus. (2010). Magizinc - The metallic coating of the future. Tata Corus.

Tata Corus. (2012). Magizinc - The innovative metallic coating for pre-finished steel. Retrieved from https://www.tatasteelconstruction.com/static_files/Tata

Steel/content/Brands/SAB/English/resources/Magizinc Brochure pre-painted.pdf

Tata Corus. (2016). Magizinc - For superior corrosion protection.

Tata steel. (2016). Magizinc Auto- The new high performance coating for inner parts and outler panels.

Retrieved from https://www.tatasteeleurope.com/static_files/Downloads/Automotive/Brochures/Tata Steel

- Magizinc Auto - Brochure EN.pdf

Thierry, D., Prosek, T., Bozec, N. Le, \& E. Diller. (2011). Corrosion protection and corrosion mechanisms of continuous galvanised steel sheet with focus on new coating alloys. Genova (Italy).

Thierry, Dominique, LeBozec, N., Le Gac, A., \& Persson, D. (2019a). Long-term atmospheric corrosion rates of hot dip galvanised steel and zinc-aluminium-magnesium coated steel. Materials and Corrosion, 1-8. https://doi.org/10.1002/maco.201911010

Thierry, Dominique, LeBozec, N., Le Gac, A., \& Persson, D. (2019b). Long-term atmospheric corrosion rates of 
hot dip galvanised steel and zinc-aluminium-magnesium coated steel. Materials and Corrosion, maco.201911010. https://doi.org/10.1002/maco.201911010

Thierry, Dominique, Persson, D., Luckeneder, G., \& Stellnberger, K. H. (2019). Atmospheric corrosion of ZnAlMg coated steel during long term atmospheric weathering at different worldwide exposure sites. Corrosion Science, 148, 338-354. https://doi.org/10.1016/j.corsci.2018.12.033

ThyssenKrupp Steel Europe. (2015). ZM EcoProtect ${ }^{\circledR}$ No room for corrosion. Retrieved from https://www.thyssenkrupp-

steel.com/media/content_1/publikationen/produktinformationen_gbb/feinblech_ov/thyssenkrupp_produktb roschuere_zmecoprotect_steel_en_sept_15.pdf

Tomandl, A., \& Labrenz, E. (2016). The corrosion behavior of ZnAlMg alloys in maritime environments. Materials and Corrosion, 67(12), 1286-1293. https://doi.org/10.1002/maco.201609076

U.S. Steel Kosice. (2015). Zinkomag / Zinkomag Plus. U.S. Steel Kosice.

Uhlig, H. H. (1979). Corrosion and corrosion control. Bilbao: Urmo de editores SA.

United States Steel Corporation (USS). (2013). Zinkomag - advanced galvanized steel sheet with improved corrosion resistance. Retrieved from file:///C:/Users/dirdvp/Downloads/Zinkomag_TEXT_Aj_2013 (1).pdf

United States Steel Corporation (USS). (2015). North American flat rolled products (pp. 10-13). pp. 10-13. Retrieved from https://www.ussteel.com/uss/wcm/connect/a2cd5f4f-0133-4201-8295-490e2490cd7e/NAFlat+Roll+Price+Extras+9-21-12.pdf?MOD=AJPERES\&CACHEID=a2cd5f4f-0133-4201-8295$490 \mathrm{e} 2490 \mathrm{~cd} 7 \mathrm{e}$

Vergokan. (2019a). General catalogue (p. 9). p. 9. Vergokan.

Vergokan. (2019b). Vergokan - Technical info. Belgium: Vergokan.

Vergokan. (2019c). Zinc Magnesium \& Zinc Aluminium - Outstanding corrosion protection. Vergokan.

Voestalpine. (2015). Voestalpine - Corronder Colofer brochures. Retrieved from http://www.voestalpine.com/colofer/en

Voestalpine. (2016). Voestalpine - Meeting Schneider Electric. Voelstalpine.

Voestalpine. (2020). This is Corrender - Corrender (zinc-magnesium-aluminum coatings) made by voestalpine. Retrieved from https://www.voestalpine.com/corrender/en/This-is-corrender

Volvo, G. (2010a). Volvo standard STD 1027,3371: Climate ageing (crack-formation). Paints and enamels. Stockholm: Volvo Group.

Volvo, G. (2010b). Volvo standard STD 1027: Corrosion resistance. Stockholm: Volvo Group.

West, J. M. (1986). Corrosión y oxidación. Fundamentos (E. L. SA, Ed.). México DF. 
Wheeling-Nipon steel. (2019a). ZAM - Corrosion protection of the 21st century. Retrieved from https://www.wheeling-nipponsteel.com/images/pdf/zam-brochure.pdf

Wheeling-Nipon steel. (2019b). ZAM - Corrosion protection of the 21st century. Retrieved from https://www.wheeling-nipponsteel.com/images/pdf/zam-introduction.pdf

Yao, C., Lv, H., Zhu, T., Zheng, W., Yuan, X., \& Gao, W. (2016). Effect of Mg content on microstructure and corrosion behavior of hot dipped $\mathrm{Zn}-\mathrm{Al}-\mathrm{Mg}$ coatings. Journal of Alloys and Compounds, 670, 239-248. https://doi.org/10.1016/j.jallcom.2016.02.026

Zamet. (2020). Recubrimiento MAGNELIS, la alternativa para los entornos agresivos. Retrieved from https://www.zamet.it/en/Magnelis-ZM-310/p/60 